\title{
Az infokommunikációs technológia hatása a földrajzi gondolkodásra
}

\author{
Doktori (Ph.D.) értekezés
}

Írta:

Sinka Róbert

Témavezető:

Dr. Csatári Bálint

egyetemi docens

Szeged

2011 


\section{TARTALOM}

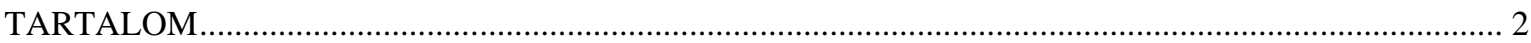

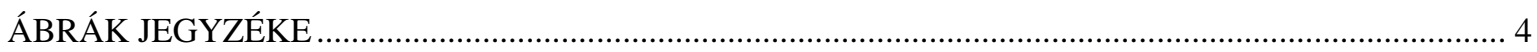

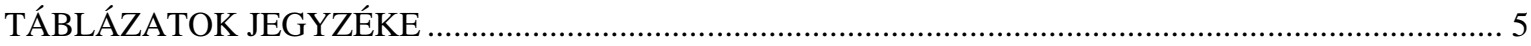

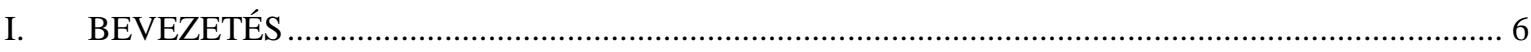

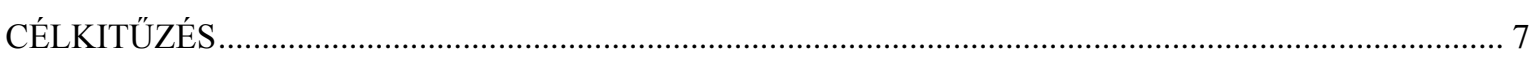

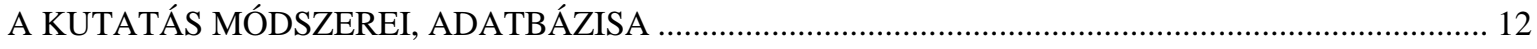

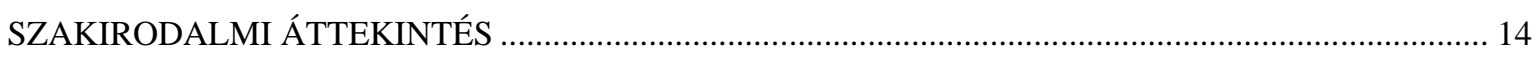

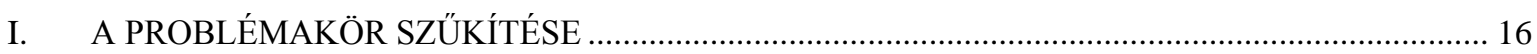

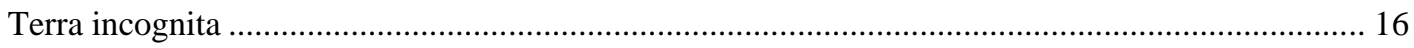

A tér és hely narratívái, tipológiai kísérletek................................................................................... 17

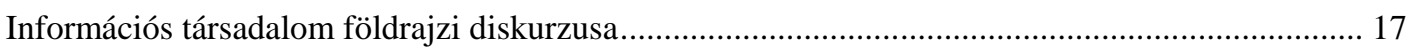

Kognitív geográfia, az ismételt bünbeesés ................................................................................ 17

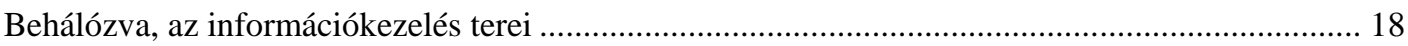

A konnektivizmus földrajza - útban a szintézis felé ....................................................................... 18

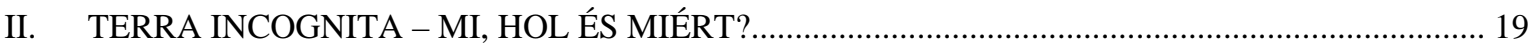

A földrajztudomány kezdete, az első lépések..................................................................................... 21

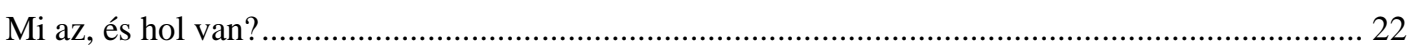

De miért? - A tudományos igényủ magyarázatok kezdete ................................................................... 24

III. A TÉR ÉS HELY NARRATÍVÁI, TIPOLÓGIAI KÍSÉRLETEK ……………………………….... 26

Világhipotézisek és paradigma-tipológia ...................................................................................... 28

A paradigmák diszkurzív és narratív megközelítése ……………………………………………...... 29

„Forradalomról forradalomra” - fejlődés és történet............................................................................. 30

Forradalmi stációk, és egy újabb diskurzusszint ........................................................................... 33

Kvantitatív forradalom, mechanikus-formalizmus ........................................................................ 33

Szociológiai irányok, kontextualista-mechanika ............................................................................ 34

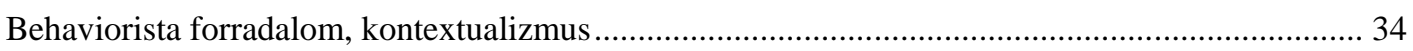

Információkezelés forradalma, a kibernetika paradigmája........................................................ 35

IV. AZ INFORMÁCIÓS TÁRSADALOM FÖLDRAJZI DISKURZUSA - TÁRSADALOMTUDOMÁNYI

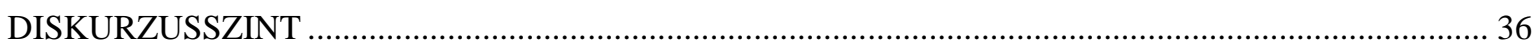

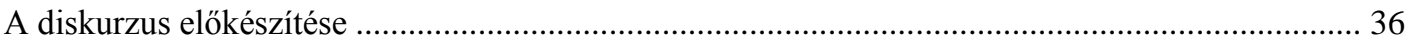

Az antropocentrikus földrajz újjáéledése ............................................................................. 38

A közösség addig terjed, ameddig az információ terjed..................................................................... 40

A geográfiai diskurzus-alapozás, újabb tipológiai bevezetô ............................................................... 44

Bevezetés az információs társadalom földrajzi diskurzusába.............................................................. 46

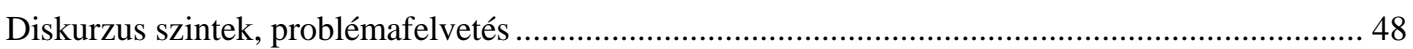




\section{AZ INFORMÁCIÓS TÁRSADALOM FÖLDRAJZI DISKURZUSA - GEOGRÁFIAI}

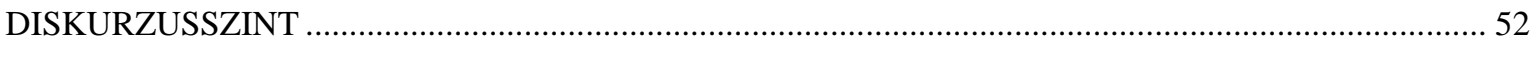

Geográfiai elméletek diskurzus szintjei........................................................................... 52

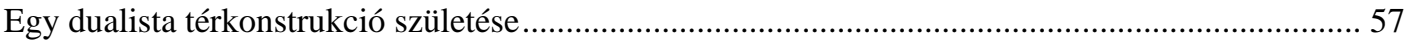

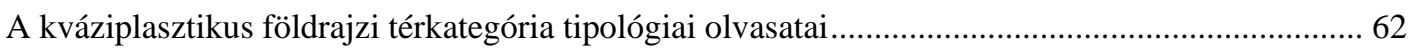

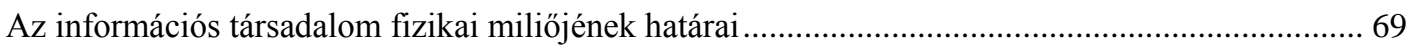

Emberi erőforrás fejlesztés - egy 'emberi diskurzus' szint ........................................................ 70

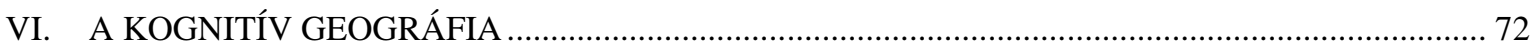

A kognitív architektúrák, mint a megismerés építökövei ........................................................... 72

Kognitív geográfia, kognitív térképek? ................................................................................. 74

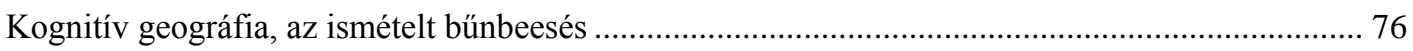

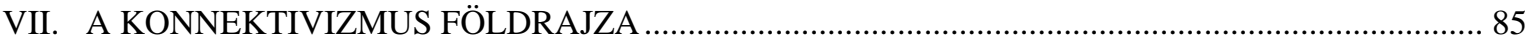

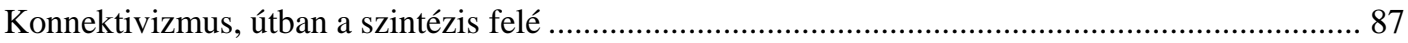

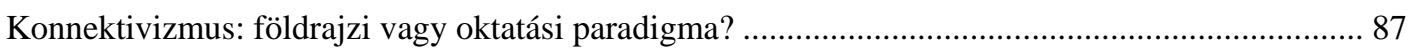

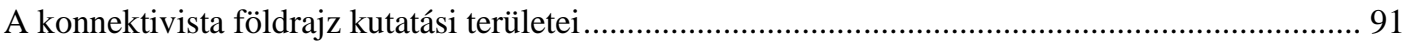

Technológia és térbeliség konnektivizmusa - a miliő diskurzusszintje ....................................... 91

Konnektivizmus, mint a humán erőforrás diskurzusszintje ........................................................ 92

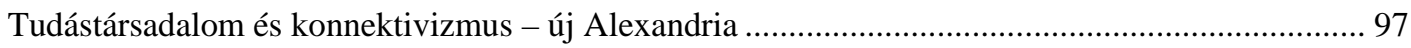

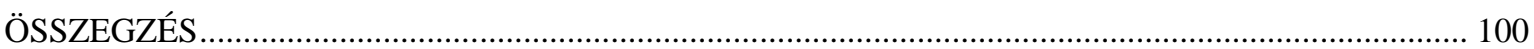

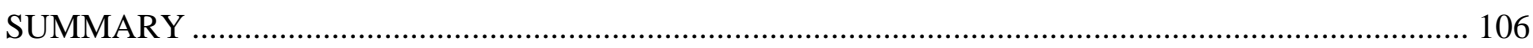

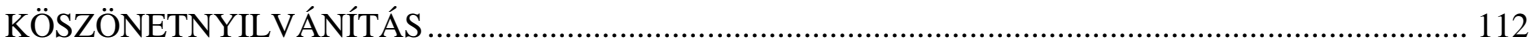

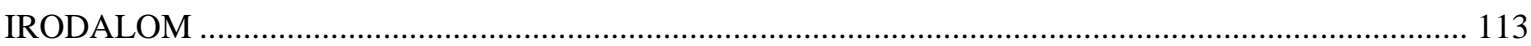

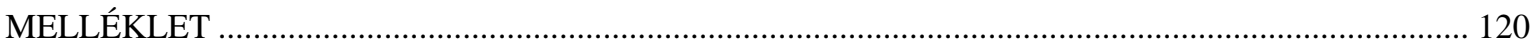




\section{ÁBRÁK JEGYZÉKE}

1. ÁBRA. A FÖLDRAJZI GONDOLKODÁS FEJLÖDÉSTÖRTÉNETÉNEK EGY LEHETSÉGES VIZSGÁLATI KERETE (A SZERZŐ ELKÉPZELÉSE SZERINT, BUTTIMER 1990, 2009, ÉS CSÉFALVAY 1990 ALAPJÁN)

2. ÁBRA. „FORRADALOMRÓL FORRADALOMRA” A GEOGRÁFIA FEJLÖDÉSTÖRTÉNETE 1945-TÖL NAPJAINKIG (CSÉFALVAY 1990, P. 57., A SZERZŐ ÁLTAL AZ EREDETIVEL AZONOS FORMÁBAN REPRODUKÁLVA) 31

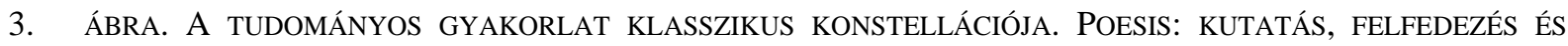

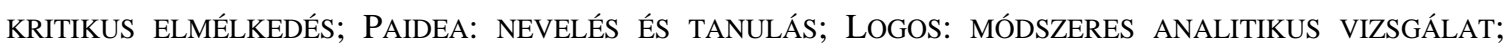
ERGON: AZ ISMERET ÉLETBEN ÉS ÉLETVITELBEN TÖRTÉNŐ GYAKORLATI ALKALMAZÁSA. (BUTTIMER 1990, P. 9)-FORDÍTÁS TÖLEM.

4. ÁBRA. FORRADALOMRÓL FORRADALOMRA, A FÖLDRAJZI GONDOLKODÁS FEJLŐDÉSÉNEK LEGÚJABB STÁCIÓJA (CSÉFALVAY 1990, SINKA 2008, A SZERZŐ KIEGÉSZÍTÉSÉVEL)

5. ÁBRA. A KÖRNYEZETÉSZLELÉS MODELLJE A „BEHAVIORISTA FORRADALOM” SZERINT (DOWNS NYOMÁN INNEN: CSÉFALVAY 1990, P. 51.)

6. ÁBRA. AZ INFORMÁCIÓS TÁRSADALOM FELBUKKANÁSÁNAK FÁZISAI (KELLERMAN 2002B, P. 11.)

7. ÁBRA. FÉSZEK MODEL - A MATEMATIKAI, FIZIKAI, SZOCIO-ÖKONÓMIAI, MAGATARTÁSI ÉS TAPASZTALATI TÉR EGYMÁSBA ÁGYAZOTT HIERARCHIÁJA COULESIS SZERINT. (COULESIS 1995, P. 232.) - AZ EREDETI ÁBRA ALAPJÁN ÁLTALAM KÉSZÍTETT REPRODUKCIÓ.

8. ÁBRA. A HELY INTERPRETÁCIÓK RÉTEGEI (KELLERMAN 2002B, P. 39, 2006, P. 130.) - FORDÍTÁS TỎLEM. 60

9. ÁBRA. TÉRBELI KOGNÍ́CIÓ ÉS KOGNITÍV TÉRKÉPEK (KELLERMAN 2007, P. 8.) - FORDÍTÁS TÖLEM. 66

10. ÁBRA. AZ EGYÉNI HOZZÁFÉRÉS KONCEPTUÁLIS MODELLJE A KIBERTÉRBEN (MEGJEGYZÉs: A GUI, GRAPHICAL USER INTERFACE - GRAFIKUS FELHASZNÁLÓI INTERFÉSZ) (KWAN 2001, P. 28.) - FORDÍTÁS TŐLEM

11. ÁBRA. A SZOCIÁLIS TÉR DIMENZIÓI (KELLERMAN 2002B, P. 32.) - FORDÍTÁS TŐLEM 80

12. ÁBRA. KAPCSOLATOK A VALÓS ÉS VIRTUÁLIS TEREK KÖZÖtT (KELLERMAN 2002B, P. 38.) - FORDíTÁS TÖLEM.

13. ÁBRA. AZ IDÖFÜGGÖ ÉS TECHNOLÓGIAFÜGGÖ HÁLÓZATI TOPOLÓGIA KAPCSOLATA

14. ÁBRA. AZ INTERNET HASZNÁLÓK KOROSZTÁLYUK ARÁNYÁBAN ÉS ISKOLAI VÉGZETTSÉG SZERINT 2002 ÉS 2006 KÖZÖTT (SINKA 2005, 2006)

15. ÁBRA. A HUMÁN INTERFÉSZ RÉS (HIG) ÉS AZ INTERNET HASZNÁLAT ÖSSZEFÜGGÉSE. (SINKA 2005, 2006) 96

16. ÁBRA. FORRADALOMRÓL FORRADALOMRA, A FÖLDRAJZI GONDOLKODÁS PARADIGMÁI 1945-TÖL NAPJAINKIG. (CSÉFALVAY 1990, SiNKA 2008, 2009 - AKTUALIZÁLVA A SZERZÖ ÁLTAL)

17. From REVOLUtion to REVOlution, the PARADigms of GeOGRAPHiCAL thinKING FROM 1945 UP tO TODAY (CSÉFALVAY 1990, SiNKA 2008, 2009 - ACTUALIZED BY THE AUTHOR) 


\section{TÁBLÁZATOK JEGYZÉKE}

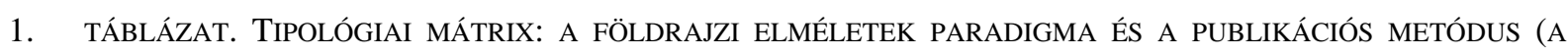
PUBLIKÁLT KUTATÁSI ANYAG JELLEGE) SZERINTI VÁZLATOS TIPOLÓGIAI ÖSSZEFOGLALÁSA. (A SZERZŐ ÖSSZEÁLLÍTÁSA) 30

2. TÁBlÁZAT. KOROK, TÁRSADALMAK, VILÁGKÉPEK - (Z. KARVALICS 2002, P. 96., *A SZERZŐ KIEGÉSZÍTÉSÉVEL)...

41

3. TÁBlÁZAT. A NÉGY TÉR ÉS TERMiNOLÓGIÁJUK COULESIS SZERINT (COULESIS 1995, P. 231.) - FORDÍTÁS TÖLEM.

4. TÁBLÁZAT. ÉSZLELÉSI OSZTÁLYOK ÖSSZEVETÉSE KELLERMAN ÉS HARVEY ESETÉBEN (A SZERZŐ ÖSSZEÁLLÍTÁSA, KIEGÉSZÍTÉSE A KOGNITÍV FOLYAMATOT KÖZVETLENÜL BEFOLYÁSOLÓ KULCS ELEMEKKEL) -FORDÍTÁS TÖLEM. 77

5. TÁBLÁZAT. VALÓS ÉS VIRTUÁLIS TEREK ÖSSZEHASONLÍTÁSA (KELLERMAN 2007, P. 12.) - FORDÍTÁS TÖLEM .84

6. TÁBlÁZAT. A HAgYOMÁNYOS GEOGRÁFIAi KUTATÁSI TERÜLETEK KONNEKTIVISTA MEGFELELTETÉSE (A SZERZÖ ÖSSZEÁLLÍTÁSA). 96 


\section{BEVEZETÉS}

Az ember biológiai és társadalom-evolúciós fejlődéstörténetének igen izgalmas szakaszához érkezett a 21. század kezdetén. Bár a változások korábban (a 20. század közepén, második felében) indulnak, az elmúlt évtized sarokköve lehet azoknak a társadalmi-gazdasági mélystruktúrákat érintő, átmozgató és újraszervező folyamatoknak, amelyet rövid, összefoglaló néven egyszerüen globális információs társadalom néven definiálhatunk.

A földrajz több ezer éves tudomány, kutatási céljai és módszerei mindig is szorosan kapcsolódtak az adott társadalom igényeihez, fejlettségi szintjéhez. Ennek értelmében az infokommunikációs technológiára (IKT) épülő információs társadalom földrajzi vizsgálata napjainkban a geográfusok egyik legújabb célterületévé vált mind az elméleti, mind az alkalmazott kutatások tekintetében.

$\mathrm{Az}$ elmúlt évtizedek információtechnológiai fejlődése példátlan változásokat eredményezett a tudományos kutatások területén és a hétköznapi életben is. Az IKT hatására felgyorsuló kommunikációs és információkezelési technikák érezhető módon egyre jelentősebb hatással vannak ránk. A napi rutint egyre több ponton érinti, és gyakran fel is váltja egy virtuális közeg, mely nem csupán a közvetlen technológiai kapcsolódást (hardver interfész) követeli meg, hanem egyre inkább egy közvetett, az emberi gondolkodásban megjelenő perceptuális kognitív erőfeszítésben is megmutatkozik. Ez a perceptuális kognitív erőfeszítés lényegében nem más, mint annak a gondolkodási folyamatnak a megfelelöje, amellyel saját földrajzi környezetünkröl infromációkat gyüjtünk és raktározunk el. Az „erőfeszítés” ebben az összefüggésben a fizikai térből származó földrajzi fogalomrendszerünk virtuális térben történő alkalmazásának nehézségét jelenti. Környezetünk észlelése, érzékelése, megismerése így újabb (nem is minden esetben a newtoni fizika szerint értelmezhető) területekre terjed ki. Az elsőre talán megfoghatatlan és nehezen értelmezhető térformákat közelebbről megvizsgálva találhatunk azonban ismerős, a geográfia számára is jól értelmezhető fogalomrendszerrel leírható elemeket is.

A földrajzi kutatások az ezredfordulót követően egyre több esetben választják témaként az információs társadalom földrajzi szemléletü vizsgálatát. Formálódik az információs társadalom földrajza, új típusú metodikája, fogalomrendszere, tipológiája. A geográfusok igyekeznek definiálni a fizikai és a virtuális térben zajló folyamatokat, jelenségeket, megfogalmazni a geográfia viszonyát az információs társadalomhoz, mint kutatási területhez. Figyelembe kell azonban venni azt a tényt, hogy napjaink tér- és társadalomdinamikájának vizsgálatkor a földrajztudomány interdiszciplinaritására talán nagyobb szükség van, mint valaha. Az információs társadalom földrajzi szemléletű vizsgálata jelenleg Magyarországon, ha nem is mellőzött, de legalábbis egy, a kívánatosnál jóval szűkebb szakmai kör érdeklődési 
területét tükrözi. A szakmai párbeszéd azonban elindult, bár igaz, hogy a lassan felfutó nemzetközi szakirodalomban is kezdetben inkább szociológiai, filozófiai és technológiai aspektusú megközelítésekből meríthetünk. (Castells 1996, Tadao U. 1963, Fritz M. 1962, Bell 1976) Ezekben a munkákban még csak közvetve jelenik meg a földrajzi szemlélet, lényegében még segédtudományi minőségében sem, jellemzően az adott tudományág fogalomrendszerébe beágyazott, az új környezet leírását definiálni akaró próbálkozásokat találhatunk. Az érdemi értelmezésekhez meg kellett várni a geográfusokat. (vö. Bakis, Kellerman, Inkinen, Paradiso, Kanalas, Nagy, Mészáros, Csatári, Jakobi, Sinka munkáival) Érdemes viszont felfigyelni, arra a tényre, hogy már a kezdeti - bár még szintén főként technológiai alapú - geográfiai szemléletü vizsgálódásokban is igen hamar teret kapnak a földrajzi ismereteinkre, gondolkodásunkra, a térbeli megismerés új formáira történő utalások, és nyomokban már elég korán felfedezhetők kísérletek is a problémakör szintézisére. (Sheppard et al. 1999, Corey és Wilson 2006, Graham 2002, 2010, Graham és Marvin 1996, 2001, Kellerman 1993, 2002, 2006 in Kellerman 2009, Mészáros 2003, Sinka 2005, 2008, Jakobi 2007)

Dolgozatom hátterét az elmúlt évtized vonatkozó szakirodalmának áttekintése adja, melyben koncentráltan az infokommunikációs eszközök földrajzi gondolkodásra gyakorolt hatását érintő munkákat igyekeztem feltérképezni. A kutatási terület szakirodalmához sokszor interdiszciplináris források elemzését is segítségül hívom (szociológiai, pszichológiai, pedagógiai, történeti, filozófiai, nyelvészeti), mert a földrajznak időnként „bünbe kell esnie” (Cséfalvay 1990) ahhoz, hogy szintetizáló erejét, és egyedi szemléletmódját megmutathassa.

\section{CÉLKITÜZÉS}

Cséfalvay Zoltán „Forradalomról forradalomra” címmel közöl ábrát egyik könyvében, amely a geográfia fejlödését mutatja be 1945-től 1990-ig. (Cséfalvay 1990, p. 57.) A dolgozatom egyik legfontosabb célkitüzése, hogy a felvázolt „forradalmakat” követő két évtized változásait megpróbáljam áttekinteni, összegezni és kiegészíteni. Hipotézisem szerint, az itt még kérdőjellel jelölt éra az információs korban testesül meg, magával hozva a geográfiai gondolkodás változását is. Az információs társadalom gazdasági hátterét jelentő infokommunikációs technológia nem csak a gazdasági-üzleti folyamatok meghatározó elemévé vált, de lassan a társadalom legeldugottabb zugaiba, legelemibb folyamataiba is eljutott, átalakítva környezetünket. ${ }^{1}$ Cséfalvay és mások (Castells 1999, Z. Karvalics 2002, Pintér 2003) következtetését követve a társadalmi átalakulás mindig magával hozta a gondolkodásban bekövetkezett változásokat. Ennek megfelelően, az információs társadalom a napjaink technológiájára épülő társadalmi forma, melyben a társadalmi berendezkedés, a 
tudásátadás és közvetítés, lényegében a gondolkodást meghatározó és befolyásoló környezeti feltételekért jelentős mértékben az infokommunikációs technológia eszköztára felelős.

A földrajzosok és más területek tudományos kutatói a legnagyobb nyertesei, haszonélvezői annak a technikai forradalomnak, amelyet a számítástechnika fejlődése eredményezett a 20. század közepétöl napjainkig. ${ }^{2}$ A földtudományok különösen sokat köszönhetnek a megnövekedett számítási teljesítménynek, és a hozzá kapcsolódó grafikai megjelenítő eszközök és programok létrejöttének. A technológiai fejlettséget, a sikeres innovációt és az új eszközök implementációját azonban mindig az határozza meg, hogy az adott társadalom milyen fejlettségi szinten áll. A közösség által birtokolt és továbbadott tudás a valódi motorja a társadalmi fejlődésének. Fontos szerep jut tehát a tudásnak, legyen az bármilyen formában és a tudás közvetítésének, szintén függetlenül attól, hogy milyen formában és technikával valósul meg. Röviden összefoglalva: „egy olyan körfolyamatot kell elképzelnünk, amelyben a kulturális és oktatási fejlődés meghatározza a technológiai fejlődést, ami meghatározza a gazdasági fejlődést, ami meghatározza a társadalmi fejlődést, ami viszont meghatározza a kulturális és oktatási fejlődést, és így tovább.”’ (Castells 1999 fordítás tőlem) Az információs társadalom architektúráját, felépítményét alkotó infokommunikációs technológiák lényegében aktív szerkezeti elemei is annak a folyamatnak, mely közvetlenül részt vesz a társadalmi tudás közvetítésében, formálásában. Történelmi tény, hogy a tudást hordozó eszközök jelentős hatással bírnak gondolatainkra, cselekedeteinkre, környezetünk belső (mentális) reprezentációjára. ${ }^{4}$

Tézis: A modern infokommunikációs technológia hatással van a földrajzi gondolkodásra. A 20. század végére, a posztindusztriális társadalmi formát meghaladó társadalmi alakulat egy olyan információs (információ-dominanciára épülö) társadalom, melynek társadalmi-gazdasági terét átszövö új paradigma a kibernetika lesz.

Batty szerint a 90-es években megjelenik a „hálózati paradigma”, melyet a késő 20. században a „komputáció (computing) paradigmája” vált fel. (Batty 1997, p. 344.) A dolgozatom elsődleges célja, hogy ennek a hatásmechanizmusnak az elemeit a környezeti észlelés szempontjából felderítsem, megvizsgáljam, és igazoljam a földrajzi gondolkodásban bekövetkező változásokat, valamint az új paradigma megszületését. Hipotézisem szerint, a modern kor technológiájára épülő társadalmi forma, melyben a társadalmi berendezkedés, a tudásátadás és közvetítés, vagyis lényegében a gondolkodást meghatározó és befolyásoló környezeti feltételekért jelentős mértékben az IKT technológia eszköztára tehető felelőssé. A kibernetika szervezi és müködteti az új paradigmát, szabályozza és vezérli a globális társadalom egészét, saját logikája szerint meghatározva benne a gazdasági - társadalmi oktatási - kulturális folyamatokat. Ennek a hatásnak az előjelei több mint egy évtizede 
megfogalmazódnak a geográfusok munkáiban, még inkább azon társdiszciplínákéban, amelyek használnak ugyan geográfiai fogalmakat, fogalomrendszereket, de alapvetően nem a térbeliség dinamikájával foglalkoznak (filozófia, pedagógia, pszichológia, szociológia, információ-tudományok, informatika, társadalomtudományok, nyelvészet stb.), illetve azt sajátos térfogalmaikkal, tér értelmezéseikkel magyarázzák. A modern IKT eszközök igen fontos szerepet játszanak ma már a környezetünk észlelésében: az internet, a televízió, az intelligens telefonok, GPS navigátorok által, és mivel az észlelés a gondolkodás egyik legfontosabb eleme, a környezeti észlelést, s vele együtt a róla alkotott gondolatainkat, mentális reprezentációinkat is képesek befolyásolni. ${ }^{5}$ (de Bono 2009., p. 121)

Tézis: Az információs társadalom tere minden esetben a valós tér elemeire épül, attól elválaszthatatlan, azzal azonos vagy ahhoz hasonló metaforikus fogalom- és szimbólumrendszerrel leírható. Ez a tér egyszerre van jelen a fizikai és a virtuális közegben, és speciális hibrid térkonstrukciót alkot.

A földrajzi vizsgálódás szempontjából fontosnak tartom, hogy meghatározásra kerüljön az a tér, amelyben korunk technológiai eszközei által kiváltott hatások közvetlenül érvényesülhetnek. A meghatározáshoz az információs társadalom térbeliségének geográfiai fogalmait, alapvető fogalomrendszerét kívánom áttekinteni. Az egyes kutatók vizsgálataik során eltérö tipológiát vezettek be. A forrásmunkákban felfedezhető, hogy közel azonos vizsgálati területen is eltérő értelmezési, tipizálási rendszert építettek fel. Az eltérő megközelítések eltérő értelmezésekben, olvasatokban kerültek publikálásra, és ezek, az úgynevezett tipológiai olvasatok egyben a módszertani alapját képezik az egyes hatásmechanizmusok értelmezési tartományának, azoknak a valós vagy virtuális téregységeknek, amelyben a jellemezni kívánt folyamatok lejátszódnak. A hazai (Mészáros 2000, 2003, Sinka 2004, 2005, 2009, 2011ab, Jakobi 2007) és a nemzetközi (Batty 1997, 1998, Dodge és Kitchin 2001, Corey és Wilson 2006, Castells 1989, 200, Inkinen 2003, 2006, Kellerman 2002, 2007, 2009) szakirodalomban meghatározó munkák áttekintése lehetőséget ad egy sajátos, egyéni, mégis megalapozott fogalomrendszer kialakítására.

Földrajzi értelemben az egymástól alig eltérő fogalomosztályok egyetlen fonal mentén is felfüzhetők, amelyet az emberi manipulációs tér kvázi-plasztikus topológiájával vagyunk képesek a legjobban modellezni, amely középpontjában minden esetben az ember áll, és a tér morfológiája, léptéke az emberi aktivitás (manipulációs képesség) intenzitásától függ. Az intenzitás mértékét elsősorban a földrajzi környezet gyakorlati alkalmazása során használt eszközök fogják meghatározni. Alacsony fokú intenzitás (eszközhasználat) esetén az ember közvetlen környezetében rajzolható ki a manipulációs tér határvonala, míg magas fokú intenzitásnál (például infokommunikációs technológia alkalmazása esetén) a manipulációs tér 
kitágul és sokkal tágabb léptéket vesz fel. Az egyes eszközök technológiai fejlettségétől, a használat időtartamától függően az emberi aktivitás terét kirajzoló manipulációs tér alakja folyton változó, plasztikus alakzat lesz. A morfológia plaszticitását azonban számos (gazdasági, társadalmi, technológiai, humán) tényező gátolhatja vagy elősegítheti, ezért az információs társadalom hibrid terét egy kvázi-plasztikus (a földrajzi tér egy adott pontján adott időpillanatban rendelkezésre álló feltételek szerinti) topológia jellemezheti a legpontosabban.

Tézis: A földrajzi információk összegyüjtése, megértése és elsajátitása egyre inkább attól függ, hogy az egyén milyen alapvetö információkezelési technikákat ismer.

A földrajzi környezetről összegyüjtött információk belső reprezentációk formájában kerülnek tárolásra, amelyek segítenek bennünket a tárgyak felismerésében, illetve az egyes környezeti objektumokhoz (entitásokhoz) köthető attribútumok eltárolásában. Ezekből a belső reprezentációkból építjük fel azokat a sémákat, melyek segítségével térbeli aktivitásunkat rutinszerüen végezhetjük el. A sémák létrejöttének feltétele, hogy létezzen belső reprezentáció, vagyis rendelkezzünk olyan tapasztalati élménnyel, amely révén eltárolhatjuk a környezeti információkat a hozzá kapcsolódó attribútumokkal.

Kutatásaim során igazolódott, hogy környezetünk belső reprezentációja, a reprezentációs sémák kialakulása annak függvénye, hogy milyen adottságokkal rendelkezünk a sémák adoptálásához, illetve mennyire fejlett agyunk feldolgozó (komputációs) képessége. Ez, az egyénenként eltérő képesség evolúciós alapokon a rendelkezésünkre áll. Ami jellemzően megkülönböztet bennünket az, hogy a környezeti információkat milyen gyorsasággal, milyen módon dolgozzuk fel, illetve életünk során milyen mennyiségü tapasztalati térreprezentációt gyüjtünk össze. Evolúciós szinten nem annyira a technológia, inkább a feldolgozás módja, technikája lesz a különbözőség forrása.

Földrajzi szempontból vizsgálva, az információs társadalom hatásterében lezajló folyamatok időbeni és térbeni dinamikáját döntően a technológia fejlettségi szintje határozza meg, amely minden esetben egyedi metódusokat igényel. A társadalom legkisebb egységének az egyénnek és a különböző méretű csoportoknak adott fejlettségi szinten adott módszertannal kell rendelkeznie. Az alapmódszerek nem nagyon különböznek, a technikai újdonságok azonban változtatnak az információfeldolgozás sebességén, s megköveteli a szereplőktől az új eszközökhöz tartozó módszertan elsajátítását, vagyis ebben a kontextusban az információ befogadásának metódusa lesz a domináns.

Tézis: Az információkezelési technikák csak közvetve függnek a technológiai fejlettségtől. Az eszközök önmagukban nem javítanak az egyén térbeli megismerési technikáin, de a tanulási folyamatok során a (valós és virtuális) földrajzi környezetböl származó 
információk befogadását elösegítő kompetenciákat alakítanak ki. Ez egy asszimilációs folyamat, amely során egyénileg különbözö kompetencia-készletek jönnek létre, attól függően, hogy az entitás milyen kompetenciák adaptálására képes. A végeredmény egy a földrajzi környezetröl aggregált tudás lesz.

A földrajzi környezetről szerzett információk kezelésének a metódusa és a technológia kapcsolatát kívánom hangsúlyozni ebben a hipotézisben. Közvetlen kapcsolatot az egyéni információkezelési technika és az IKT között az entitás metakognitív attribútumainak minősége és számossága határozza meg. Metakogníció alatt a saját tudásunkról rendelkezésre álló tudást értem, amelyet a hosszú távú emlékezetben tárolunk, és elsősorban a saját tudásunk működtetésének ellenőrzésére használjuk fel. Ennek értelmében az entitásnak rendelkeznie kell azzal az ismerettel, amellyel fel tudja mérni, hogy saját kompetencia-készletében rendelkezésre állnak-e azok az elemek, amelyekkel képes a térben számára megfelelő döntéseket hozni. Döntéseinek sikerét ezért metakognitív attribútumainak minősége és számossága fogja meghatározni. A metakognitív jellemzők előtérbe kerülése egyértelmüen $a$ tudás felértékelődését jelenti. A fizikai és virtuális tudáshálózatok szerveződése, hálózati architektúrája, térbeli elrendeződése és topológiája a hálózati elemek minden egyes szintjén tudáshordozóként és tudásfeldolgozóként viselkedik. Az IKT alapú hálózatok topológiája robusztus, nagy hibatürő képességgel rendelkezik, számos esetben az evolúciós megoldásokhoz hasonlóan. Az evolúció azonban nem mérnök, lépésről lépésre haladt, minden esetben tökéletesen müködő megoldásokat hagyva maga után.

A megismerés, beleértve a környezetünk térbeli megismerését is, igen erős kölcsönös függést (interdependenciát) mutat a tanulási képességek fejlődésével, és fejlettségi szintjével. Ez a függőség evolúciónkban lépésről lépésre alakult, azt is mondhatnánk: annyira gyorsan voltunk képesek felfogni a környezetünket, amilyen gyors mozgásra voltunk képesek. Az észrevehető változást véleményem szerint az ipari forradalomtól rohamtempóban fejlődő közlekedési hálózatok hozták, amelyre közvetlen utalást is találunk például Erdősinél (2005). Ezt követően nem volt megállás, és az érzékeinket egyre több technológiai eszköz akarta kiegészíteni, jobbítani, esetenként helyettesíteni. Ennek eredményeképpen napjainkban már a kibernetikus organizmusok megjelenésére számíthatunk. Kezdetben, orvosi implantátumokban, később - és ezek a kutatások gyakorlatilag az ajtónkban kopognak az eredményeikkel - a kiborgok általános jelenlétével lehet számolnunk. A folyamat azért feltünő, mert rendkívül gyors. Gyors abban az értelemben, hogy az evolúció által kialakított érzékszervek helyett asszimilált technológia jellemzően átveszi a még ép szerv felett az uralmat. Elsorvasztva azt. Az egyén metakogníciója, környezetéről alkotott tudása az agyi feldolgozási sémákról egy egyszerübb feldolgozási szisztémát vesz át. A súlyponteltolódás egyben a standardizáció veszélyét hordozza magában. 


\section{A KUTATÁS MÓDSZEREI, ADATBÁZISA}

Áttekintés: Az emberi gondolkodás fejlődése több ezer éves fejlődés eredménye. Az evolúciós fejlődés lassú, kimért lépéseihez képest azonban napjainkban olyan változásoknak lehetünk tanúi, amit az elmúlt évtizedekben még nem is remélhettünk. Úgy tủnik azonban, nem egyszerüen a változás a lényeg, hanem a változások sebessége, mozgásának iránya és globális hatásmechanizmusa. Hagyományosnak tekinthető geográfiai fogalmak szorulnak rá az újraértelmezésre, és a geográfusok is kényszer alatt állnak, hogy a megváltozott társadalmi környezetben a megfelelő fogalmakat megalkossák és definiálni tudják. A tér-idő kapcsolatok, a környezet, a lokalitás, a szomszédság elve, a topológia, a földrajzi léptékek és mértékegységek, a mérés és a térképezés eszközei, módszerei, a tér-reprezentáció mind-mind új értelmezést kap. Lehet, hogy nem kell átírni minden fogalmat, de újragondolni egészen bizonyosan szükséges.

A kutatás alapvető célja, hogy földrajzi szempontból számba vegye a legfőbb változási irányokat, trendeket, szükebb értelemben pedig megvizsgálja a környezetünk észlelését, megértését befolyásoló, módosító modern technológia valós vagy vélt hatásait.

Fogalmak, definíciók: A kezdeti hipotézisek felállítását követően össze kellett gyüjteni a szükséges fogalmakat. A további munkák során az előzetes fogalmak módosultak, pontosításra szorultak, ezért több szakaszban a fogalmak újragondolását, újradefiniálását is el kellett végezni. Az összegyüjtött fogalmakat a későbbiekben érdemes lenne fogalomgyüjtemény formájában, a szükséges magyarázatokkal ellátva publikálni. A dolgozatban most az egyes fogalmak ott kerülnek magyarázatra, ahol elsőként előfordulnak, amennyiben mégsem, azt jeleztem. A geográfiai és más fogalmak nem különülnek el egymástól, nem készült szakterületekre elkülönített fogalomtár, a téma együttes értelmezését szolgáló valamennyi kifejezés megtalálható, elsősorban a jegyzetekben.

Kapcsolódó kutatások: Kutatás szervesen integrálható a geográfiai kutatások, azon belül az információs társadalomhoz kötődő eddig megjelent elemzési irányokhoz. A jelen kutatás számos geográfiai és társadalomtudományi aspektusú információs társadalmat elemző irányzathoz szervesen kapcsolódik, azok eddigi eredményeire épít. A technológiai (Kanalas 2003a, 2003b, Nagy 2001, 2002, 2004, Nagy és Kanalas 2009), a szociológiai (Pintér 2003, 2004, Csotó és Székely 2009), a társadalomfilozófiai (Z. Karvalics 1999, 2002) a filozófiai (Farkas 2002, Varga 2003.), a kultúrantropológiai (Rab 2007) és egyes szintetizáló munkákkal (Sinka 2004, 2009b, 2009c, Mészáros 2000, 2003, Csatári 2003 in. Kanalas 2003b, Kellerman 2002b, 2007, 2009b) is koherens és konzisztens a kapcsolata.

Adatgyüjtési módszerek: A kutatás döntően elméleti jellegéböl adódóan az adatgyüjtés elsődlegesen a szakirodalomi forrásgyüjtésre és azok elemzésére épül. A gyüjtőkört az 
előzetes olvasmányok, valamint azok a szakmai közösségek határozták meg, amelyek a témakörrel már szorosabban foglalkoztak. Itt elsősorban a magyarországi Információs Társadalom Oktató és Kutatóközpont (ITOK) munkatársai, kutatói, valamint az International Geographical Union (IGU, Nemzetközi Földrajzi Unió) szakbizottsága, a Geography of the Global Information Society Commission ${ }^{6}$ (Globális Információs Társadalom Földrajza Bizottság) tagjainak kutatási eredményeit, publikációit tekintettem primer forrásnak. Ebbe a kategóriába tartoznak még azok a forrásmunkák is, amelyeket olyan magyarországi kutatók jelentettek meg, akik valamelyik hazai regionális kutatóintézetben, vagy önállóan tevékenykednek a témában.

A szekunder források összegyüjtésében a primer források hivatkozásaira építettem, miközben igyekeztem elkerülni a kereszthivatkozásokat, és adott problémakörhöz a tézist a lehető legjobban alátámasztó, a problémakör tisztázását leginkább elősegítő munkánkra koncentráltam. Ennek eredményeképp már nagyon hamar be kellett vonni olyan társdiszciplínákat is, amelyek a primer körben még nem szerepelhettek.

Statisztikai adatok: Az adatgyüjtés másik nagy csoportja a statisztikai adatok gyüjtése, értékelése, összehasonlítása. A statisztikai adatok - lévén elméleti munkáról - primer köre többnyire az elsődleges forrásokból származott, a másodlagos, ún. szekunder adatbázisok közül a KSH statisztikai adatbázisát ${ }^{7}$, az ITTK kutatási jelentéseit és adattábláit ${ }^{8}$, a World Internet Project (WIP) kutatási jelentéseit és adattábláit ${ }^{9}$, valamint az Eurostat adatbázisát ${ }^{10}$ használtam fel. Az ettől eltérő (ad hoc) forrásokat a felhasználás helyén jelölöm.

Kvantitatív analízis: A feldolgozandó források és adatok mennyiségi elemzése. A kutatáshoz felhasznált források és adatok mennyiségi meghatározása elengedhetetlen a kutatás határainak kijelöléséhez: térben, időben, problémakör tekintetében. Az előzetes hipotézisem szerint az általam vizsgált problémakör jellemzően az ezredfordulót követő egy évtizedben lezajlott társadalmi-technológiai folyamatok eredménye. Tágabb értelemben - jórészt a szekunder hivatkozások miatt - vissza kellett nyúlnom ennél tágabb időintervallumra is, de ezt csak nagyon indokolt esetben tettem meg. Már az adatgyüjtés meghatározásánál sikerült lehatárolnom egy olyan kutatói bázist, amely mennyiségileg még kezelhető, mégis átfogó és releváns forrásnak tekinthető. Az adatbázisok adatai esetében is hasonlóan jártam el.

Kvalitatív analízis: A források és adatok minőségi elemzése. A minőségi adatelemzés elsődleges szempontja a forrás volt, a másodlagos a tárgyalt témakör szempontjából történő hasznosítás lehetősége. Nem használtam és közlök olyan adatmennyiséget, elemzést, mérési adatot, amely nem nyújt egyértelmű megfeleltetést a tézis-elemzéseimmel kapcsolatban. Teljes mértékben elkerültem azokat az adatokat is, amelyek forrása nem igazolható, vagy kizárólag becslésre alapul. A primer források kvalitatív analízise tekintetében - a szinte 
kizárólag referált folyóirat, könyv miatt - a publikációs forrás belső hitelesítésére (a lektorálásra) hagyatkoztam.

A témakör tárgyalása: A dolgozat kifejtése, a problémakör részletes elemzését tartalmazza. A megfogalmazott tézisek mentén, az egyes rész problémakörök lehető legszegmentáltabb vizsgálatával igyekszem a mélyebb összefüggéseket feltárni, a jelenség magyarázatához a válaszokat megtalálni. Bár a választott téma túlzott aktualitása miatt könnyen adhatnánk azt a választ, hogy a témakör még nem vizsgálható, nem rendelkezünk elég rálátással, a folyamatok gyorsasága azonban ennek ellentmondó, hatások jól érzékelhetök, bár a fogalomrendszer még formálódik, a keretrendszer stabil. A tézisek egyenként hasonló elrendezésben kerülnek tárgyalásra: problémafelvetés, fogalomtisztázás, analízis, modell/sémaalkotás, értékelés, összefoglalás fejezetenként, a dolgozat legvégén pedig átfogó szinopszis készült.

\section{SZAKIRODALMI ÁTTEKINTÉS}

A dolgozat megírását előkészítő legfontosabb források, szakirodalmi művek áttekintésével fel kívánom vázolni azt a gondolati folyamatot, amely a kutatás problémakörének kirajzolását, elméleti hátterét indukálta. Az alábbi művek együttes hatására fogalmazódottak meg a kérdések: A földrajzi gondolkodás fejlődése véget ért vagy egy újabb szakaszához érkezett? Ha ez egy új szakasz, csupán apró változásokat hozott vagy gyökerestül felforgatta az addigiakat? Milyen szerepet játszhatnak a modern eszközök a térbeli megismerés folyamatában? Létezik-e felismerhetö kapcsolatrendszer a technológia müködése és az érzékelés mechanizmusa között? Lehetséges lenne modellezni az új társadalmi formához kötődő fizikai és virtuális teret pusztán a megismerés folyamataira koncentrálva? Az olvasmányok bővülésével pedig szerencsére nem csak a kérdések szaporodtak, hanem a válaszok is.

Cséfalvay Zoltán, Térkép a fejünkben c. könyve (Cséfalvay 1990) számomra a földrajzi gondolkodás fejlődését tárgyaló, magyar nyelven elérhető munkák egyik legprovokatívabb diskurzusgeneráló darabja. Az alapprobléma gyorsan megfogalmazódik: a földrajzi gondolkodás nem valamiféle statikus, önmagában érdektelen kérdéskör, hanem az emberi fejlődés nagyon is integrált része. Ráadásul, nem csak az derül ki belőle, hogy a környezetünk érzékelése biológiai-társadalmi evolúció terméke, hanem az is, hogy a folyamat nem zárt, még akkor sem, ha felfedezhető benne a ciklikusság, a diskurzus folytatható.

Anne Buttimer munkáit is felhasználva (Buttimer 1969, 1974, 1976, 1980, 1990, 1999) a földrajzi gondolkodás fejlődésének történeti alapjait áttekintve egy tér-idő-paradigma skála állítható fel, amelyet dolgozatom alaptézisének fogok vizsgálni, feltételezve, hogy ez a skála 
folytatható és a folytatás maga a diskurzus folytatása. A skálán kirajzolódó, a földrajzi gondolkodást forradalmasító irányzatok és azok kapcsolatrendszerei nem csak Cséfalvay megfogalmazásában „forradalmiak”. ${ }^{11}$ A második világháborút követően számos geográfus fordult a tudománytörténet és a filozófia felé. Intenzív kutatások indultak a megváltozott gazdasági-társadalmi környezet, a technikai újítások által provokált környezet és tudományosfelelősségvállalás megértése érdekében. Olvasmányaim alapján ez a szakmai úm. öndefiníciós kényszer napjainkra sem csitult el, s talán ez az oka annak, hogy a megismerés paradigmák forradalmi és evolúciós nézőpontjai nem tisztultak le. ${ }^{12}$

A földrajzi diskurzushoz való csatlakozás lehetőségét megelőzte egy kitérő, amely bevezetett a magyarországi információs társadalmat kutatók szük, ám igen lelkes csapatába (2003). ${ }^{13}$ A döntően társadalomtudománnyal foglalkozó kutatóknak köszönhetően megismerhettem azokat az ismeretelméleti alapokat, szakmai közösségeket, amelyek az információs társadalom történeti (Z. Karvalics 1995, 1999, 2002, 2007), szociológiai (Pintér 2003, 2004, Csotó és Székely 2009), filozófiai (Farkas 2002), néprajzi és kultúrantropológiai (Rab 2007) aspektusait a saját szakterületükön belül kutatták. Az ITOK munkatársainak közössége szélesre tárta a vizsgálati irányok nyújtotta lehetőségek ablakát, utat és teret adva a földrajzi szemlélet számára, amely tökéletesen beillett ebbe a sokszínű, az információs társadalom értelmezésén „fogást kereső” csoportba.

A földrajzi vizsgálatok kezdetben, talán csak a társadalomtudósok munkáihoz képest, de bátortalanabbnak tüntek. A geográfusok egy markáns csoportja főként a hagyományos statisztiai-elemző geográfia hagyományaira építve a technológiai aspektusú kutatásokat preferálta (Kanalas, Csatári, Nagy, 2003), bár megjelentek szociálgeográfiai indíttatású munkáik is (Kanalas 2003b, Sinka 2005), amelyek már helyenként a társadalomtudományokkal fedésben, komplexebb értelmezésekkel próbálkoztak (Jakobi Á. 2007). Jakobi Ákos doktori disszertációja, illetve az alapjául szolgáló könyv, Az információs társadalom térbelisége (2007) pedig már egy jóval érettebb, átfogóbb munka.

A téma valódi kinyitását az a nemzetközi kapcsolat jelentette, amely megismeréséhez éppen az infokommunikációs technológia segített hozzá, és ami egyszerre jelentett kaput egy nemzetközi geográfus közösséghez való személyes csatlakozáshoz, és lehetőséget a megmérettetésre. Ezért az IGU Globális Információs Társadalom Földrajza Bizottság ${ }^{14}$ tagjainak, szakmai közösségének a visszajelzése az egyik legfontosabb szakmai csatorna a kutató munkám tekintetében. Az ok egyszerü, a magyarországi kutató közösség nem csak számosságában szük, bár lelkes kör, de kutatási forrásait, a publikációi témaköreit tekintve jórészt az országhatáron belül maradnak. Erre kiváló példa a NETCOM 2009-ben megjelent, általam szerkesztett különszáma, amely a magyarországi információs társadalom kutatóknak, és persze a magyar információs társadalomnak adott lehetőséget a nemzetközi 
bemutatkozásra. A vizsgálati módszerek, kevés kivételtől eltekintve, nehezen vethetők össze nemzetközi szinten, bár megfigyelhető a konvergencia néhány cikkben (Kanalas és Nagy 2009, Sinka 2009, 2011a). A dolgozat témáját illetően meghatározó Aharon Kellermann (Kellerman 1989, 1999, 2000, 2002b, 2006, 2007), Maria Paradiso (Paradiso 2003, 2006), Mark Wilson, Corey (Wilson és Corey 2000, 2006, Wilson, Corey et al. 2001), Tommi Inkinen (Inkinen 2003, 2005, 2006) és az IGU Globális Információs Társadalom Bizottság többi tagjának munkái.

\section{A PROBLÉMAKÖR SZÜKÍTÉSE}

A dolgozat célkitüzéseinek áttekintésekor megfogalmaztam a legfontosabb téziseket, amelyek tárgyalását a dolgozat szempontjából relevánsnak érzek. A problémakör szükítéseként az alábbi területek tárgyalását tekintem fontosnak.

\section{Terra incognita}

A modern infokommunikációs technológia hatással van a földrajzi gondolkodásra, amely annak a biológiai és társadalom-evolúciós fejlődésnek a közvetlen, természetes eredménye, amelyet az emberi gondolkodás a környezet megismerésében eddigelé bejárt. Miközben Cséfalvay gondolatmenetét követem, a mi, hol és miért kérdésekre keresem a választ, a földrajz legősibb gyökereiben keresve a támasztékot. Az alapozás gondolatmenete nem öncélú, segít a rendszerezésben és megkönnyíti felderíteni a különbözőségeket, módszertani segítséget ad a bizonyításhoz (forradalom vagy evolúció), és nem utolsó sorban a csoportelméleteken keresztül elvezet napjaink legizgalmasabb kutatási területére, a hálózatok tudományához.

Nem foglalkozom részletesen az 1945 előtti tudománytörténeti és tudományfilozófiai kérdésekkel. Az indoklás: egyrészről terjedelmi okok miatt nem szorítható be a negyvenöt előtti tudománytörténeti és tudományfilozófiai elméletek feldolgozása, másrészről nem releváns a kitűzött alapvető céllal szemben, miszerint Buttimer és Cséfalvay megkezdett diskurzusához szeretnék csatlakozni. A diskurzushoz csatlakozás biztosíthatja a kellő tudományos keretet, melyhez egyéni nézőpontom a feldolgozás során illeszthetővé válik. 


\section{A tér és hely narratívái, tipológiai kísérletek}

A földrajzi tér és hely eltérő narratívái mind egy-egy tipológiai kísérletnek tekinthetők. Hipotézisem szerint az információs társadalom, a társadalom-evolúciós fejlődési szakaszok egyik meghatározó, de egyáltalán nem végleges stádiuma. Szerepe, jelentősége abban mutatkozik meg, hogy kijelöli a poszt-indusztriális társadalmak gondolati fejlődésének mintázatát, meghatározva azok technológiai aspektusú interdependenciáját; továbbá rámutat az infokommunikációs technológia és az emberi gondolkodás genetikai párhuzamaira. Tér és hely viszonyának tipológiai kísérletére biztatva előkészíti az információs társadalom földrajzi aspektusú diskurzusát.

\section{Információs társadalom földrajzi diskurzusa}

A földrajznak is el kell fogadnia, hogy szintetizáló tudományként csak akkor tud kiteljesedni, önálló szemléletmódot tükrözni, ha egy másik tudományterület földrajzi elemzésénél elfogadja annak egyes vizsgálati metódusait. Így értelmezhetővé válik az, hogy a társadalomtudományokban gyakori 'diskurzusok szerinti megközelítést' a geográfiai elemzéseknél is be kell vezetni. Kiváló példa erre az információs társadalom tere, amely minden esetben a valós tér elemeire épül, attól elválaszthatatlan, azzal azonos vagy ahhoz hasonló metaforikus fogalom- és szimbólumrendszerrel leírható. Ez a tér egyszerre van jelen a fizikai és a virtuális közegben, meghatározva azt a miliőt, amelyben az aktuális társadalmi folyamatok zajlanak. Az információs társadalom tere nem vizsgálható minden elemében tisztán definiált földrajzi fogalomként, ezért szükség van a földrajzi diskurzus módszerének bevezetésére.

\section{Kognitív geográfia, az ismételt bünbeesés}

A földrajzi információk összegyüjtése, megértése és elsajátítása egyre inkább attól függ, hogy az egyén milyen alapvető információkezelési technikákat ismer. A kognitív geográfia a pszichológia aktuális, a kibernetika paradigmájával releváns eredmények szintézisével tesz kísérletet arra, hogy a behavioristák eredményeire építve a technológia által létrehozott virtuális terek észlelését, mint virtuális környezetészlelést leírja. Az abszolút földrajzi környezetben megismerhető térbeli objektumokhoz képest (ahol valamennyi érzékszervünk egyszerre fogadja be és dolgozza fel az információkat) itt elsősorban az agyi müködés által stimulált percepciók müködnek. A belső reprezentációkban történő tárolás, feldolgozás, adaptáció során kialakult sémák tükröződnek vissza az egyéni reprezentációkban, és azok 
feldolgozott publikációiban. Az információs technológiák arra késztetnek bennünket, hogy standard és egyéni humán interfészeket fejlesszünk ki annak érdekében, hogy az információs társadalom aktív és ne szenvedő polgárai lehessünk. A kognitív geográfia arra tesz kísérletet, hogy felderítse ennek a földrajzi megismerésre és a térbeli magatartásra (tájékozódás, napi aktivitás) vonatkozó összefüggéseit.

\section{Behálózva, az információkezelés terei}

Az információs társadalom háttér infrastruktúrája a hálózat. A hálózat alatt pedig napjainkban jóval többet értünk, mint kommunikációs alapinfrastruktúrát. A hálózat ma már önálló logikával rendelkező, ún. hálózati eszközrendszerből, hálózati elemekből épül fel, amelyek önmagukban is képesek müködni, egyedi intelligenciát hordozva magukban, és együttmüködésre képesek, ráadásul dinamikus protokolokon keresztül. A kölcsönös megfeleltetés (mutual compatibility) képessége az információs társadalom globális terjedésének a szuperfegyvere. Az információkezelési technikák csak közvetve függnek a technológiai fejlettségtől. Az eszközök önmagukban nem javítanak az egyén megismerési technikáin, de a tanulási folyamatok során adaptálható kompetenciákat asszimilálnak tudás formájában. Közvetlen kapcsolatot az egyéni információkezelési technika és az IKT között az entitás metakognitív ${ }^{15}$ attribútumainak minősége és számossága határozza majd meg.

\section{A konnektivizmus földrajza - útban a szintézis felé}

A földrajzban létező vizsgálati területek újraszervezését, az információs társadalomhoz illesztését jelenti a konnektivizmus földrajza. Hipotézisem szerint, az információs társadalom a modern kor technológiájára épülö olyan társadalmi forma, melyben a társadalmi berendezkedés, a tudásátadás és közvetítés, lényegében a gondolkodást meghatározó és befolyásoló környezeti feltételekért jelentős mértékben az IKT technológia eszköztára tehető felelőssé. A kibernetika szervezi és müködteti az új paradigmát, szabályozza és vezérli a globális társadalom egészét, saját logikája szerint meghatározva benne a gazdasági társadalmi - oktatási - kulturális folyamatokat. A konnektivizmus a paradigma inherens logikája. A konnektivista szemlélet egy módosult szerepkör, a hálózati társadalom aktorait jellemző magatartásforma. Kapcsolódása a hálózati elemeken keresztül valósulhat meg, melynek egy technológiai és egy humán interfész (konnektivista kompetencia portfólió) vetülete lesz. A konnektivista geográfia, ha nem is teljesen tartalmában, de szerkezetében új, a paradigma által kijelölt irányokat fog jelenteni a geográfusok számára. A kompetencia alapú 
tudástársadalom kialakítása lesz a következő szakasz, amely már az információs társadalom egy maturációs fázisa lehet. Az információkezelés uralma véglegesé és elfogadottá válik.

\section{TERRA INCOGNITA - MI, HOL ÉS MIÉRT?}

Ebben a fejezetben több elméleti irányt is elindítok. A vezérfonal természetesen a földrajzi megismerés gondolati-evolúciója, de a később becsatlakozó tézisek megértéséhez szükséges néhány szálat már itt elindítani. A térbeli megismerés alapkérdéseinek a tárgyalása mellett ezért be kell vezetni olyan kutatók munkáit is, akik nem geográfusként vizsgálódtak a témában, eredményeikre mégis építhetünk. Ennek a „bünbeesésnek” az oka egyszerü: a környezet megismerése a legritkább esetben önálló, még kevésbé öncélú tevékenység, emiatt meg kell említeni a csoport-elméleteket; és a környezetet leíró információkészlet dinamikája $^{16}$, a megismerés folyamatában játszott szerepe miatt pedig, a hálózatok keletkezésével kapcsolatos néhány témakörrel is érdemes már itt foglalkozni. Kezdjük a vizsgálódást egy rövid kitérővel.

„Mindanyian felfedezők vagyunk”, kezdi fejtegetését Alastair Bonnett What is geography? c. könyvének bevezetőjében. (Bonnett 2008) Velem is előfordul, hogy a beszélgetések során az emberek úgy tekintenek rám, mint felfedezőre, világjáróra, aki mindent tud, mi merre van a világban. Megkérdezik tőlem, hogy „ez vagy az a hely hol van”. Ezeket a kérdéseket rendszerint valamelyik magazinból vagy TV müsorból hallják és meglepődnek, ha nem tudom a választ! „Neked tudnod kell, geográfus vagy!” - Erre rendszerint azt szoktam válaszolni, hogy „mondd, meg hol van, akkor megmondom, miért van ott!” Úgy vélem ez az egyik alapvető különbség a földrajzi problémák szakmai és a hétköznapi megközelítési módja között. A tudományos igényü megközelítések azonban jellemzően nem érdeklik, vagy csak igen „felületesen” az embereket. A „felületesség” ez esetben inkább az „érthetőség” fogalmával azonosítható, és nem valamiféle igénytelenséggel. ${ }^{17} \mathrm{~A}$ mindenki számára jól érthető, a hétköznapi földrajzi problémákat is emberközelbe hozó magyarázatokra mindig is szükség volt. Éppen ezért lehetséges, hogy a „public geography” iránt manapság erősödő igény sokkal régebbi keletű, mint azt elsőre gondolnánk. Csatári Bálint az Alkotó Alkalmazott Geográfusok alakuló ülésén három alkalmazott földrajzi feladatkört hangsúlyozott: ${ }^{18}$

(1) „A földrajznak múlhatatlan szerepe van a „reális világ”, a természeti és a humán világ dialektikus személetben történő megértésében, illetve az ebben való kísérletezésben. Ez a tudás másokhoz eljuttatva jelentősen befolyásolja térismereteiket, sőt viselkedésüket is. Ebben a tekintetben tehát a földrajzi tudás 
eleve egyfajta potenciális alkalmazást jelent. Az első alkalmazott földrajzi feladat tehát a dialektikus geográfiai világismeret és látásmód ápolása.”

Szeretném felhívni a figyelmet az idézetben megfogalmazott első feladatkörre: „a dialektikus geográfiai világismeret és látásmód ápolása”, mely által felhalmozott és átadott tudás „,befolyásolja térismereteinket, söt viselkedésünket is”. A figyelem itt két dologra összpontosul: az egyik a tudás felhalmozás, a másik az átadás. Itt ugyan nem esik szó a felhalmozás és az átadás eszközrendszeréröl, módszereiről, és arról sem, ami valamennyi tudás allokáció kritikus funkcionális jellemzője: hogyan tud hálózatba szerveződni, miként tudja elérni a terjedéshez szükséges küszöbértéket, létre tud-e jönni egy innovációt támogató skálafüggetlen topológia, amely végeredményben nem lesz más, mint egy klasszikus társadalomfejlődési modell? (Castells 1990, p. 13.) De erről a konnektivista földrajz tárgyalásánál lesz még szó. Annyit elég most rögzíteni, hogy Csatári Bálinttal egyetértve, a földrajzi tudás terjedése hatással van a gondolkodásunkra és viselkedésünkre. A gondolatmenet egyébként a vezérfonalként szolgál a dolgozat hipotéziseinek bizonyításához.

(2)”A második a tudástermelés. Olyan tudásé, amelyik segíthet a társadalmat nyomasztó problémák megoldásában. Erős alkalmazott geográfiai irányzatok dolgoznak a környezet- és a fejlesztéspolitika, a város és regionális tervezés megalapozásán. Ezek a legismertebb és leggyakoribb alkalmazások.”

A tudástermelés, másként fogalmazva a geográfiai tudás allokáció minden korban, minden történelmi környezetben a társadalmi fejlödés meghatározó eszköze volt. Az első, kezdetleges formái, amelyek leginkább leíró jellegűek voltak, megalapozták a későbbi tudományos igényű elemzéseket. Bár számos példát említhetnénk a történelemben, amikor a fejlesztéspolitika ezzel szemben haladt, az adatok összegyüjtése, rendszerezése, tárolása, továbbra is a tervezési-fejlesztési feladatok alapját jelenti. Ha nem szorítkozunk itt a magyarázatnál szorosan a tervezés-fejlesztés fogalmára, akkor vegyük észre, hogy mik a metódus elemei: adatgyüjtés, rendszerezés, tárolás. A későbbiekben szükség lesz, a fentebb említett, megismerést befolyásoló gondolattal együtt erre is.

(3) „A harmadik feladat, vagy talán mondhatnánk küldetésnek is: szakértői tevékenységek végzése az állam, a kormány és az önkormányzatok, illetve a civil társadalom számára.”

Ez a fajta tevékenység, földrajzi ismeretszerzés és átadás nem csupán a tudományos kutatások támogatását szolgálja, nyomait napjainkban az ismeretterjesztés, és az ún. közföldrajzi (public geography) szemléletü törekvésekben is felfedezhetjük, különösen angolszász és német nyelvterületen. Ezek a tevékenységek persze önmagukban is megállják a helyüket, nem is céljuk valamiféle forradalmi megoldást alkalmazni, inkább egy általános cél megfogalmazására törekednek. Ilyen például, amely megvizsgálja a népszerü vagy közföldrajz 
létrehozásának és kommunikációjának a lehetőségeit, hogy aztán tevékenysége által képessé tegye az embereket egy tágabb értelemben vett szociális, gazdasági, környezeti igazságosság elérésére.

A látszólagos kitérőnek a célja az, hogy felhívjam a figyelmet a földrajzi információk terjedésének, közvetítésének nagyon is aktuális igényére, és a megoldási lehetőségek nehézségeire. A környezetünket leíró információk a modern információkezelő technológiáknak köszönhetően olyan mértéket értek el, amelyet az emberi agy már nem képes önállóan sem tárolni, sem feldolgozni. Ennek következtében a továbbítás (újra publikálás) sem megoldható korszerü kommunikációs eszközök nélkül. Mindez azért fontos a számunkra, hogy megértsük a technikai fejlödés által provokált probléma aktualitását, s amelyet a közföldrajz képviselői már megfogalmaztak a civil társadalom felé: szakértő módon publikált információk közvetítése a lehető legközérthetőbb formában, a lehető legtöbb csatornán keresztül. A földrajz megnyitása a civilek felé önmagában nem újdonság, az ismeretterjesztés régóta ellátja ezt a feladatot. Amiért mindez a közföldrajz okán mégis említésre került, amitől valójában aktuális és napirenden van, az nem más, mint a megvalósítás módja, a felhasznált technológia által kikényszerített módszertan, az információk szervezésének technikája és a mindezek által újraszerveződő földrajzi ismeretek agyi reprezentációkban okozott zavara (perceptuális redundanciák, PDP feldolgozási hibák, SZÁR, FSR, PDP és az ágens architektúrák harca stb.). ${ }^{19}$

Mielőtt kinyitnánk a földrajzi információk belső és külső reprezentációja közötti kapcsolatrendszert, és rávilágítanánk az információfeldolgozás emberi és gépi folyamatai közötti párhuzamokra, tekintsük át a földrajzi gondolkodás fejlődésében kijelölhető fontosabb mérföldköveket és a köztük kirajzolódó folyamatokat. ${ }^{20}$

\section{A földrajztudomány kezdete, az első lépések}

A geográfusok feladata több mint kétezer éve, hogy a földrajzi környezetet és az abban zajló térbeli folyamatokat megértsék és leírják. A geográfiai kutatások sokáig csak ezt a leíró jelleget hordozták magukon. ${ }^{21}$ A „,erra incognita”, az ismeretlen föld felfedezésének, alapos megismerésének a vágya, és az ezzel felhalmozódó ismeretanyag eredményezte később a földrajz tudományos igényü megalapozását és virágzását. ${ }^{22}$ Ezek az események az emberiség történelmében jellemzően a gyarmatosításokhoz vagy a nagy földrajzi felfedezésekhez kötődtek. A terület természeti kincseinek a kiaknázása alapos természeti földrajzi, a meghódított területek lakosságának leigázása és az uralom fenntartása pedig lényegében társadalom- és gazdaságföldrajzi ismereteket követelt. ${ }^{23}$ 
A földrajzi ismereteink gyarapítása érdekében az első kérdések, amiket megfogalmaztunk: a „mi, hol van”? Az ősembertől a felfedezőkön és a hódítókon keresztül napjainkig igen fontos kérdések ezek. ${ }^{24} \mathrm{~A}$ mi, hol és a miért? - kérdéshármas azonban csak a társadalom-evolúció magasabb fokán jelenhetett meg. A földrajzi gondolkodás kezdeteit így nem egy mesterségesen létrejött tudomány termékeként kell elfogadnunk, hanem mint az emberiséggel egyidős ,szellemi természetű időtöltés”. (Cséfalvay 1990, p. 27.)

\section{Mi az, és hol van?}

Ez a két kérdés még viszonylag egyszerűen megválaszolható, bár a válaszok igen eltérő mintázatot követhetnek. Az egyes társadalmi csoportok létszámától, az általuk a földrajzi környezetböl elfoglalt tér méretétől és az információközvetítés technikájától ugyanis függ a válasz tartalma (mennyiségi-minőségi paraméterei). Ahhoz, hogy ezt megértsük, érdemes foglalkoznunk Norbert Wiener ${ }^{25}$ néhány ide kapcsolódó gondolatával. ${ }^{26}$

Egy kisebb léptékü közösség vizsgálatakor, például egy ősközösségi horda méretü csoport esetében néhány tíz emberből álló csoportot definiálhatunk. Az általuk elfoglalt (birtokolt) néhány négyzetkilométeres „térszeleten” belül ők, alig lépik túl az egyéni információkészlet kezeléséhez és közvetítéséhez szükséges szintet. Vagyis az entitás (egyetlen egyénből álló) szintü, vagy csoportelemi (kettő-három kapcsolódó entitásból álló) szintű méretet ${ }^{27}$, így ez a szükségleti szintek legalsó fokát jelenti. ${ }^{28}$ A környezeti információk ilyen alacsonyfokú közvetítésének a szintje egyértelműen az önellátásra, a legprimitívebb igények kielégítésére szorítkozik csupán. Mivel az ember alapvetően társas lény, így az egyéni kérdésfeltevés és válaszadás csak a kezdeti, az említetthez hasonló fázisban értelmezhető, így ha valaki a csoportból rájön a megoldásra, rövidesen átadja a megszerzett információt a csoport többi tagjának, és az egyéni információkészlet a csoport részévé válik, elkezdődik a hálózati struktúra kialakulása, amely az elemi szint robbanásszerü növekedését is magával hozhatja. ${ }^{29}$

Geográfiai szempontból is érdekes, ha elfogadjuk Wiener tételét, hogy „a közösség csak addig terjed, ameddig a tényleges információátvitel terjed” (Wiener 1974, p. 161.), akkor elfogadható az is, hogy a társadalmi csoportok növekedésével egyre fejlettebb információkezelési technikákra is szükség van. Ellenkező esetben nem csak a megszerzett földrajzi ismeretek szigetelődnek el egymástól, de a társadalmi kohézió - lényegében a kollektív információs-adatbázis, más néven információközösség - széthullásával a harmadik kérdés, a miértek megválaszolása is bizonytalanná válik. A csoport növekedése együtt jár a tér növekedésével is, amely kauzális következménye az információmennyiség bővülésének. Minél tovább növekszik tehát a csoport, illetve a társadalom tagjainak a létszáma, annál 
nagyobb lesz a térigénye, amihez egyre több földrajzi információt is kezelnie kell. ${ }^{30}$ Ez csak úgy oldható meg, ha szervezettebb társadalmi formát alakítanak ki, amely szintén elképzelhetetlen anélkül, hogy (az adott kor szintjén) a lehető legfejlettebb információkezelési technológiát alkalmaznák. A technikai újítások így visszahatnak - nem csak a társadalmi - a földrajzi környezetről alkotott világkép kialakítására is. ${ }^{31}$ „A kicsi, szorosan összetartozó közösségek homeosztázisának a mértéke igen jelentős: és ez így van akár civilizált országban magas müveltségű közösségekről, akár primitív vadak falvairól van szó.” (Wiener 1974, p. 165.) Minél nagyobb a közösség, a homeosztázis, annál nehezebben tartható fenn.

\begin{abstract}
„Olyan társadalomban, amely túl nagy ahhoz, hogy tagjai közvetlenül érintkezhessenek egymással, a homeosztázis fenntartása érdekében információs céleszközöket és eljárásokat, illetve (további növekedés esetén) információkezelést támogató célszervezeteket hoznak létre. A nagyobb egészt „ebben a tevékenységében az információ megszerzésére, felhasználására, tárolására és továbbítására szolgáló eszközök birtoklása tartja össze.” (Wiener 1974, p. 165.) 32 $^{32}$
\end{abstract}

Wiener gondolatát követve: a kommunikációs és az információkezelési technika fejlődése, intenzív jelenléte a közösség homeosztázisának alapja, végső soron a társadalmi koherencia záloga. Napjainkban ezt a globális IKT hálózatok - és a hozzá kapcsolódó, erre épülő szervezetek - alapozzák meg. Ezt a gondolatot egyes irányzatok futurisztikus ideológiaként, mások technológiai determinizmusként élik meg, amit az emberiségnek végig kell járnia, mint például Hoyer ${ }^{33}$, aki az irányzat elsőszámú képviselőjének egyértelműen Marshall McLuhan ${ }^{34}$-t jeleöli meg. ${ }^{35}$ A kutatók többségével egyetértve, azonban inkább a technológiai eszközök semlegessége mellett érvelnék, mindamellett, hogy hatásukat meghatározónak tartom, de tartózkodnék annak idealisztikus megközelítésétől. ${ }^{36}$ Ráadásul, a gondolatmenet idealisztikus levezetésével szemben áll egy anti-homeosztatikus tény, amelynek köszönhetően az utópia vélhetően soha nem következik be, vagyis hogy a csoport összes tagja nem asszimilálhatja a közösség összes tudását, mint ahogy a közösséget irányító rendszer sem teheti magáévá az összes egyéni információkészletet. De ez a gondolatmenet már átvezetne bennünket a hálózati tanulás, a tudásmegosztás új paradigmáinak megvitatásához, amelyről a későbbi fejezetekben lesz még szó.

A társadalom fejlettségét, a társadalmat körülvevő földrajzi környezetről alkotott és elfogadott világképet természetesen nem csak az egyes populációk mérete, a kulturális színvonal vagy a technikai fejlettség határozza meg önmagában. Ennél összetettebb a kép. Röviden a bevezetésben már esett szó arról, hogy: egy olyan körfolyamatot kell elképzelnünk, amelyben a kulturális és oktatási fejlődés meghatározza a technológiai fejlődést, ami meghatározza a gazdasági fejlődést, ami meghatározza a társadalmi fejlődést, ami viszont meghatározza a kulturális és oktatási fejlődést, és így tovább. ${ }^{37}$ (Castells 1999, Z. Karvalics 
2002) Az infokommunikációs technológia az összekötő és szervező technológia ebben a körfolyamatban, a társadalmi homeosztázis, wieneri megfogalmazásában fentebb tárgyalt, fenntartása érdekében létrehozott és működtetett eszközök. ${ }^{38}$

A földrajz kétezer éves paradigmája volt a mi az és hol van kérdésre adott válasz, így a földrajzi gondolkodás kezdeti fejlődési szakasza lényegében szervesen összekapcsolódott az ember biológiai és társadalom-evolúciós fejlődéstörténetével.

$\mathrm{Az}$ eddig tárgyalt problémakörben igyekeztem kiemelni a klasszikus paradigma megközelítésből azokat az elemeket, amelyek fejlődése napjaink társadalmának szerkezeti felépítését alapozták meg. Mielőtt ezeknek a struktúráknak a felépítményét is megtárgyalnánk, egy újabb kitérőre lesz még szükség: a geográfia tudományos igényü magyarázatainak, a miértekre adott válaszok rövid tudománytörténeti bevezetésére. Az újabb kitérő célja, hogy a további szakirodalmi hivatkozásokban fellelt elméleti munkák beágyazottságát kellően előkészítse.

\section{De miért? - A tudományos igényü magyarázatok kezdete}

A harmadik kérdés - a miért - megválaszolása, hipotézisem szerint azonban már nem csak a csoportok vagy a csoport tagjainak a számától függ, jóval inkább a birtokolt információ mennyiségétől, minőségétől és az információkezelési technikától (ez elsősorban módszer és csak részben lesz a technológia kérdése). A „miértekre” adott válasz már jóval összetettebb logikai műveleteket is megkövetel az első két kérdés lineáris, és kauzális összefüggéseihez képest, ezért a tér észlelése, mint információfelvételi mechanizmus evolúciós beágyazottságára hagyatkozik, és inkább a feldolgozási sémáján javít, mintsem teljes reprezentációs tárakat épít. A dolgozat eredményeinek végül majd ezzel a kérdéskörrel kell összhangba kerülnie.

A földrajzi jelenségek ok-okozati összefüggéseinek megválaszolására persze több alternatíva is kínálkozik. Az egyik alapvető megoldás a racionális-logikai, a másik a vallásimitológiai. (Cséfalvay 1990, p. 27.) Például a folyók áradása következtében megtermékenyített alföldek, egy vulkán kitörése vagy a tenger szintjének változásai mérhető és (matematikailag) kiszámítható fizikai folyamatok sorozatával leírható jelenségek. A vallási keretben megfogalmazott válaszok - egy-egy istenséghez kötődően - azonban jelentősen leegyszerüsítik a jelenségekre adott magyarázatokat. Azt is mondhatjuk, hogy a földrajzi gondolkodás egy vallási-mitológiai keretrendszerben jóval egyszerübb, sematikusabb és könnyebb válaszokat eredményez, mivel a válaszokat egy (vagy több) istenséghez rendeli, akik azt isteni hatalmuknál fogva azokat rövid úton el is intézik. ${ }^{39}$ Az európai kultúrán nevelkedett fejlett világ azonban jobban kedveli a racionális-logikus keretrendszerbe illeszthető válaszokat. Ennek gyökereit elsősorban a görög kultúra virágkorában találjuk 
meg. ${ }^{40}$ Ez a fajta, tradicionális geográfiai gondolkodás föként a 19., részben a 20. század közepéig meg is maradt. Ennek a legfőbb oka, hogy a földrajz a 19. századig nem volt önálló tudomány. ${ }^{41}$ Az önállóság megszerzése (a 19. század első felében) azonban leginkább a túlélést jelentette, aminek ára volt. Az addig társtudományként művelt geográfiából letisztult tudományágak születtek, s a földrajznak megmaradt a leíró jellege. Ezzel a tradicionális földrajzzal szemben ott állt Bacon analitikus kutatási módszerei, Galilei és Descartes természeti törvényei és Newton matematikailag leírt mechanikus világképe. „Az új tudományos világszemlélet tulajdonképpen nem tudott mit kezdeni a tradicionális földrajzzal. A világ térbeli rendjének a leírása nem elégítette ki a tudományosság mércéjét, ehhez mechanikus-kauzális összefüggésekre és egzakt matematikai formulákba önthető törvényekre lett volna szüksége.” (Cséfalvay 1990, p. 30.)

A miértekre és a tudományos igényű magyarázatokra a földrajz új irányzata, a kvantitatív geográfia adta meg a választ. ${ }^{42}$ A harmincas-negyvenes évektől pedig egyre erősebb az ehhez kapcsolódó rendszerszemlélet. A geográfiai kutatásokban is ez válik dominánssá: a térbeli rendszerek vizsgálata. ${ }^{43}$ A geográfián belül lényegében korlátlan számú rendszert tudunk létrehozni, csak éppen kezelhetetlenné válik. Ennek a megoldhatatlan feladatnak a feloldására - miszerint a kvantitatív geográfiának kellene kaotikus világunkat a rendszerelmélet segítségével megmagyaráznia, leírnia - született meg a modellképzés (ún. modell-geográfia). A geográfia nagy átváltozása, a leíró jelleg levetkőzése sikerrel járt. A kvantitatív geográfia „megszabadította magát a túlzott verbalizmustól, a „mi, hol van” pozitivista alapkérdésétől.” (Cséfalvay 1990, p. 37.) A szigorú matematikai, föleg közgazdasági törvényszerüségeken nyugvó kvantitatív modellekben a tér formálja az embert, az ember engedelmeskedik a földrajzi környezet törvényszerüségeinek. A racionálisan megtervezett térben az ember is formálható, ami a II. világháború utáni kor szemléletével tökéletes összhangban is volt. Ami miatt mégsem maradt egyeduralkodó ez az irányzat annak volt köszönhető, hogy a geográfia tudománya - a kvantitatív forradalomnak köszönhetően nem csak a túlzott verbalizmust vetette le magáról, de kihagyta a térbeli folyamatok főszereplőjét: az embert is.

Az ellentámadás nem váratott sokáig. A kvantitatív geográfiai szemléletet az emberközpontú földrajzi szemlélet váltja fel. A 20. század második felében pedig már a „behaviorista forradalom” az, amely alapvető geográfiai axiómákat kérdőjelez meg. Az ókori euklidészi - térgeometrián és a newtoni fizikai-matematikai értelmezések egy objektívan leírható, racionálisan felépülő, 3D térről beszélnek. Az elmúlt kétezer év geográfiai tudományos munkája épült erre. Ezzel szemben az 1960-as évektől megjelent írásokban azonban a tér szubjektív értelmezése, sajátos tudati leképeződése jelenik meg. ${ }^{44}$ Downs hamar felismeri, hogy „a tér észlelésének a földrajzi kutatása csupán egy része a geográfia 
általánosabb fejlődésének, nevezetesen a behaviorista forradalomnak, amely nyilvánvalóan, az eltünőben lévő kvantitatív forradalom helyébe lép majd...”. (Downs 1970 in. Cséfalvay 1990, p. 49.) A behaviorista forradalom, a földrajz újkori megújulása még nem ért véget. A 20. század második felétől az ember térbeli magatartásának, térformáló tevékenységének/aktivitásának és térformáló szerepének az előtérbe kerülésével ismét emberközpontú földrajzi irányzatok születnek. ${ }^{45}$ A behaviorista forradalommal egyidős, de csak a 20. és 21. század fordulóján kiteljesedő irányzat az információs társadalom földrajza. ${ }^{46}$ Az egyik legfiatalabb, s úgy tünik, tartósan az érdeklődés középpontjában maradó kutatási irányzat alapjait kétségtelenül a kvantitatív elemzők rakták le. És akik a folytatásban szerepelnek: matematikusok, filozófusok, számítógépes szakemberek, szociológusok, történészek, pszichológusok, antropológusok, és természetesen a geográfusok. A kezdetben technológiai determinizmusként kezelt axióma, miszerint a modern infokommunikációs technológia hatással van a földrajzi gondolkodásra, jelentős szegmentációs folyamaton ment keresztül. S bár az eltelt idő nem tünik túl hosszúnak, az ezzel a keresztmetszettel foglalkozó kutatók eredményei azt mutatja, hogy ez a folyamat annak a biológiai és társadalomevolúciós fejlódésnek a közvetlen, természetes eredménye, amelyet az emberi gondolkodás a környezet megismerésében eddigelé bejárt.

A földrajzi gondolkodás hajnalán tehát nem csak az információ összegyüjtése, a mi az, és hol van primitív, létfenntartó aspektusú kérdésére kellett választ adni, hanem arra is: mennyire lehet képes az ember evolúciós fejlödése során arra, hogy társas lénnyé váljon, hovatovább, az önzésből némileg engedve, megossza a megszerzett információkat, információközösséget létrehozva pedig társadalmakat építsen. A következő fejezetben tipológiai kísérletet teszek az információs társadalom földrajzi célú vizsgálatának előkészítéséhez, miközben hagyom, hogy a földrajz újra és újra „,bünbeessen”. ${ }^{47}$

\section{A TÉR ÉS HELY NARRATÍVÁI, TIPOLÓGIAI KÍSÉRLETEK}

Az alábbi fejezetben kísérletet teszek egy elméleti tipológia-rendszer értelmezésére, és megpróbálom saját elméletemet ehhez illeszteni. Mindeközben igyekszem előkészíteni a terepet a kutatási területem tipológiai rendszerének tárgyalásához, megteremtve azt a paradigma-kontextust, amelybe kellően beágyazható, és a szakmai diskurzushoz való csatlakozása tisztán értelmezhető. 
A földrajz „bűnbeesése” más tudományágakkal nem új keletü. ${ }^{48}$ A pszichológiával történő házasság csak tovább erősítette a tudomány interdiszciplinaritását, azt a nyitottságot, amellyel képes mind a mai napig az új dolgokat magába fogadni és megtermékenyíteni. A gyermek neve behaviorista geográfia lett. ${ }^{49} \mathrm{~A}$ második világháborút követő geográfiai kutatások paralel fejlődési pályát futnak be az újjáépítés és a gazdasági-politikai újrarendeződés mentén. A '90-es évek kelet-európai fordulata, a kétpólusú világ összeomlása, a globalizációt képviselő gazdasági, pénzügyi és társadalmi formációk egyértelmű előretörése mind ugyanabba az irányba mutattak: egy poszt-indusztriális társadalmi formáció stabilizálódását jelezve. A folyamat eredményeképpen ma információs társadalomnak nevezett társadalmi alakzatot természetesen nem az említett években találták ki, a társadalom minden zugát átható manifesztálódása azonban mégis az ezredfordulóra érett be. Hipotézisem szerint az információs társadalom, a társadalmi-evolúció fejlődési szakaszának jelenleg meghatározó, de egyáltalán nem végleges stádiuma. Szerepe, jelentősége abban mutatkozik meg, hogy kijelöli a poszt-indusztriális társadalmak gondolati fejlődésének mintázatát, meghatározva azok technológiai aspektusú interdependenciáját; továbbá rámutat az infokommunikációs technológia és az emberi gondolkodás genetikai párhuzamaira. Tér és hely viszonyának tipológiai kísérletére biztatva előkészíti az információs társadalom földrajzi aspektusú diskurzusát.

A probléma nem új keletü, Buttimer már 1969-ben felveti egyik cikkében (Buttimer 1969, p. 417), hovatovább ő maga is még régebbre mutat, Juel Sion egyik 1908-as tanulmányának említésével. Buttimer természetesen nem az információs társadalomról, annak tipológiai problémáiról beszél, inkább arról elmélkedik, hogy a földrajznak meg kell-e maradnia a hagyományosan objektív alapokon, elegendő a fundamentalista szemlélet vagy teret kell adnia más, például szubjektív dimenzióknak is. A konkrét felvetés így szól:

„Drámai és izgalmas kihívások várnak ma a geográfusokra. Az empirikus társadalmi mintákban bekövetkezett forradalmi változások sok tradícionális analitikus eljárást elavultá tettek; a tudományos világ radikális átalakulása kérdéseket vetett fel a társadalomtudomány eljárásainak filozófiai megalapozottságával kapcsolatban. A behavioristák és egzisztencialisták felteszik a sarkalatos kérdést: továbbra is betölthet-e a tudomány hasznos szerepet a társadalmi valóság objektív felszíne és az alatta zajló mechanizmusok mérésével és magyarázásával, vagy figyelembe kell vennie és magába foglalnia szubjektív dimenzióit is? ${ }^{50}$ Edward $\mathrm{T}$. Hall ${ }^{51}$ igen meggyőzően fogalmazza ezt meg: az idő és a tér beszél? Az idő és tér néma nyelve miként befolyásolja az emberiség kulturális eltéréseit? A geográfusok azt a kérdést teszik fel maguknak: elégedjünk meg a térbeli társadalmi minták egy átlátszatlan, objektív térképének felvázolásával, vagy ki kell ezt egészítenünk a szubjektív vagy belső nézőponttal? ${ }^{52 » " ~(p . ~ 417) ~}$ - fordítás tőlem. ${ }^{53}$ 
Ezek a drámai és izgalmas kérdések ma is foglalkoztatják a geográfusokat. A drámaisága legtöbbször abban jelentkezik, hogy a magyarázatokhoz szükséges tipológiai rendszer nem áll rendelkezésre, vagy nem illeszthető azonnal a meglévőkhöz. A hagyományos analitikai eljárások az információs társadalom vizsgálati módszereiben is az első fogódzót jelentették a geográfusok számára, a fogalomrendszer finomítása még csak ezt követően jelenik meg az irodalmakban (vö. Kellerman 1989, 2002, 2006, 2007; Sinka 2004, 2005, 2008; Jakobi 2007; Bakis és Roche 1998 és mások munkái). Buttimer kérdésfeltevése egyértelmüen elővetítette a behavioristák 80-as évekbeli színrelépését, evvel együtt a geográfus praxis értelmezési tartományának kitágítását.

\section{Világhipotézisek és paradigma-tipológia}

A paradigma-konstellációk értelmezéséhez Cséfalvay (pp. 54-55.) Stephen C. Pepper ${ }^{54}$ világhipotéziseit hívja segítségül. ${ }^{55}$ Az organikus (organicism), a formalista (formism), a mechanikus (mechanism), és a kontextualista (contextualism) világnézeti elméletek mentén formálódó paradigmák a földrajzi gondolkodás fejlődés-paradigmáinak tipizálásához adnak segédkezet. Az organikus szemlélet végig visz bennünket a földrajzi elméletek teljes spektrumán, elég csak a Gaia elméletekre gondolnunk. Nehéz levetkőzi annak a csábítását, hogy a történések mögött evolúciós magyarázatokat lássunk, ekkor ugyanis át kellene értelmeznünk a dialektikus magyarázatokat is. A „paradigma szerint a térbeli képződmények - lett légyen szó egy folyóról vagy egy lakótelepről - biológiai életciklusokat futnak be, változásaik a születés, az érés, a kiteljesedés és az elöregedés stádiumaival írhatók le.” (p. 54.)

A formalizmus az a szemlélet, amely ,az alapja a geográfia legerősebb vonulatának, a geomorfológiának, melynek módszertani hatása - településmorfológia néven - még a társadalmi jelenségek vizsgálatára is kiterjedt." ${ }^{56}$ (p. 54.)

A mechanikus világnézet is a nevében hordozza az általa uralt szemléletet. A világ gépként történő értelmezése könnyen szerez híveket, racionális magyarázatokat, kauzális kapcsolati rendszert építhetünk fel mögé. Ez a világnézet talán a legkönnyebben illeszthető egy indusztriális társadalmi rendbe, ahol a társadalmi folyamatokat eleve a technokrata szemlélet uralja. A geográfusnak nincs más dolga, mint hogy „feltárja a térbeli rendszerek belső oksági kapcsolatait, és ennek alapján tanácsokat adjon a gépezet célszerü müködtetéséhez.” (p. 54) Érdemes észrevennünk, hogy a „gép metaforája” meglehetősen kor függő, a bevezetőben már több szempontból érintett társadalom-evolúciós szakaszhoz köthető, a csoportszinteket és azok információkészletét jelentősen befolyásoló tényező.

A kontextualizmus paradigmája egy pragmatikus paradigma. ${ }^{57}$ A világot alkotó elemek kontextusán, kapcsolatán és kölcsönhatásán alapuló, de alapvetően a gyakorlati működésre, 
mechanizmusra összpontosító rendező elv. Kiemelt hangsúly van az összefüggések rendszerén, így a geográfus dolga az, hogy „a térben lejátszódó eseményeket a lehető legtágabb összefüggésrendszerben tárja fel.” (p.55) A rendszer szerveződésének bonyolultsága miatt gyakorta vizsgálnak egyedi kapcsolatrendszereket, meg sem próbálva a teljes rendszeranalízist, feltételezve annak túlzott komplexitását.

Mint majd látni fogjuk, a későbbi fejezetekben az információs társadalom elemzésénél, és a bekapcsolódó problémakörök esetében sem lehet nélkülözni az itt vázolt szemléleti módokat, hovatovább egy új rendező elvet is csatasorba kell állítanunk, a kibernetikai paradigmát, mint a társadalmat szabályozó, vezérlő szemléletmódot. Mindezek előtt azonban beszéljünk a felsorolt paradigmák különböző megközelítési módjairól. A következő elméleti megközelítés Buttimer nézőpontjainak értelmezését szolgálja, s két célja van: az egyik, hogy értelmezési pontokat biztosítson a Cséfalvay által felvázolt elmélethez; a másik, hogy interfészként funkcionáljon az infokommunikációs eszközök földrajzi gondolkodásra gyakorolt hatásának elemzéséhez, beágyazva azt az eddigi tudományos igényü diskurzusok sorába, mint ahogy arról a fejezet bevezetőjében már említést tettem.

\section{A paradigmák diszkurzív és narratív megközelítése}

A paradigmák diszkurzív és narratív megközelítése lényegében a szakmai nézőpont, a geográfus szakma értelmezési vetülete, amelyen keresztül az aktuális paradigmák mentén álláspontját ki tudja alakítani. Az álláspontok meghatározása, részben a paradigma hatása miatt, ölthet diszkurzív és narratív köntöst is. A következtető (diszkurzív) szemlélet jellemzően a cselekvő nézőpont köré szerveződik, és társai ergon és paidea, míg a teremtő közlés hatását előnyben részesítő (narratív) szemléletek a szabályok mentén szerveződő gondolati folyamatokkal (áttételesen a teremtő tudás és logika) párosíthatók, és társai a poesis és a logos lesznek. (vö. Buttimer 1983, 1990, 2001)

A diszkurzivitás a gyakorlatot hangsúlyozza (ergon és poesis) és így közelebb áll a mechanikus és kontextualista világszemlélethez. A narrativitás a mintázat szerveződésére figyel (paidea és logos), melyet így jellemzően az organikus és formalista paradigmákhoz kapcsolhatunk. Mint ahogy azt alább látni fogjuk, nincs tiszta rendszer. Az alábbi táblázatban általam készített összefoglalás a tipológiai rendszer könnyebb áttekintését szolgálja, és nem próbál meg elméleti direktívaként szolgálni. Ennek a paradigma-kauzalitás lehet a legfőbb oka, így ún. tiszta rendszereket aligha találunk. Tisztán, soronkénti logikai kapcsolat ezért nem definiálható, az elrendezés közelítő megfeleltetés csupán. 


\begin{tabular}{|l|l|l|}
\hline Publikációs metódus & Nézőpont & Paradigma \\
\hline \multirow{2}{*}{ Narratív } & paidea & organikus \\
\cline { 2 - 3 } & logos & formalista \\
\hline \multirow{2}{*}{ Diszkurzív } & ergon & mechanikus \\
\cline { 2 - 3 } & poesis & kontextualista \\
\hline
\end{tabular}

1. táblázat. Tipológiai mátrix: a földrajzi elméletek paradigma és a publikációs metódus (a publikált kutatási anyag jellege) szerinti vázlatos tipológiai összefoglalása.

$\mathrm{Az}$ alábbi ábra a tipológiai kísérletek során kirajzolódó nézőpontok előzetes összefoglalása. Együtt ábrázolva ,a földrajzot körülvevő társadalmi, gazdasági és kulturális miliőből” (p. 53.), a hivatalos paradigmából, és a földrajzi gondolkodók egyéni szemléletmódjából kirajzolódó kapcsolatrendszer közepén a földrajzi gondolkodás fejlődéstörténetére ható tényezők sematikus modellje rajzolódik ki. Amelyet egy időskálán elhelyezve, később az egyes rendszereket elkülöníthető és összevethető paradigma-miliőszervezö-kontextusban ábrázolhatjuk.

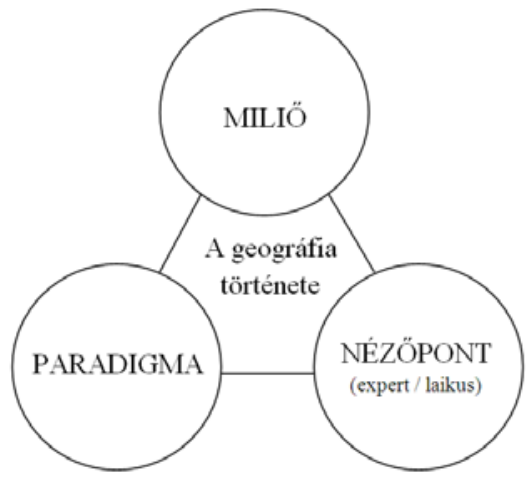

1. ábra. A földrajzi gondolkodás fejlödéstörténetének egy lehetséges vizsgálati kerete (a szerzö elképzelése szerint, Buttimer 1990, 2009, és Cséfalvay 1990 alapján)

\section{„Forradalomról forradalomra” - fejlődés és történet}

A tudományos paradigmák váltakozása mindig felveti a kérdést, elülteti a kétkedést, hogy a váltás forradalmi vagy „ csak” evolúciós. ${ }^{58}$ Az eddig tárgyalt tipológiai keretek egyértelmüen lehatárolásra törekednek, módot és fogódzót is adnak, de tiszta viszonyokat nem teremtenek. Ennek oka vélhetően az, hogy a paradigma alapvetően kauzális természetü, nincs önmagában és önmagáért, így könnyen felfedhetök benne úm. a régi korok gyümölcsei. Cséfalvay 1990-ben megjelent könyvében egy, a fentebb levezetett paradigma-kontextust is felhasználó ábrát közölt, „Forradalomról forradalomra” a geográfia fejlődése 1945-töl napjainkig címmel (p. 57.), amelyben Anne Buttimer elgondolását is követi: ${ }^{59}$ 
״ [...] a geográfia vázlatosan ismertetett története három alapvető tényezö összjátékának, kölcsönös egymásra hatásának eredményeként fogható fel. Először is, nem hagyhatjuk figyelmen kívül azokat az elvárásokat, amelyek a földrajzot körülvevő társadalmi, gazdasági és kulturális miliőből származnak. Másodszor, a geográfusok konkrét tudományos teljesítménye nem érthető meg az éppen uralkodó földrajzi világszemlélet, az ügyeletes paradigma nélkül. Harmadszor pedig — lévén a geográfus is ember — be kell vonnunk az elemzésbe a vállalható és megélhető szakmai szerepek körét is. A földrajz mint tudomány, tényleges teljesítménye tehát mindig e három tényező a miliő, a paradigma, és a szakmai szerep - bonyolult kombinációjának az eredője.” (p. 53.)

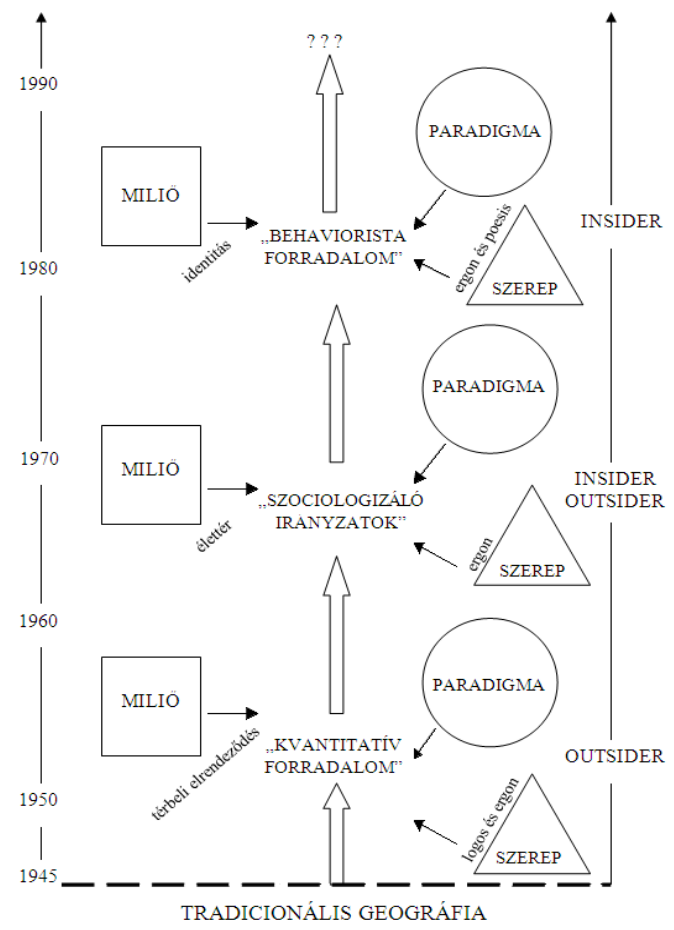

2. ábra. „Forradalomról forradalomra” a geográfia fejlödéstörténete 1945-töl napjainkig

(Cséfalvay 1990, p. 57., a szerzö által az eredetivel azonos formában reprodukálva)

Az ábra lényegében egy tér - idő - paradigma skála, amelyben a mozgástér az adott miliö, az idö, az időtengelyen feltüntetett és mérföldkőként jelölt év, míg a paradigmák a szakmai nézőpontokkal együttes konstellációi jelenítik meg az aktuális földrajzi világnézetet. Érdemes mindjárt itt foglalkozni röviden a miliő kérdésével. Ez az aspektus a társadalmi gazdasági - kulturális környezet makro, mezo és mikro szinten értelmezhető térbeliségre utal. A térbeliség szerepköre ebben a fogalomrendszerben az a tipizált környezet, amelyben a vizsgált földrajzi események lezajlanak és térbeli kerete mozgásteret biztosít az uralkodó paradigma számára. A miliő oppozíciójaként Buttimer szakmai szerepköreinek konstellációját - részben már tárgyalt módon - találjuk. A szakmai körökhöz rendelt fogalmi-szempontokat (melyeket még eltérő nézőpontokra is oszt később) az alábbiak szerint képzelte el (Buttimer 1990, p. 9): ${ }^{60}$ 


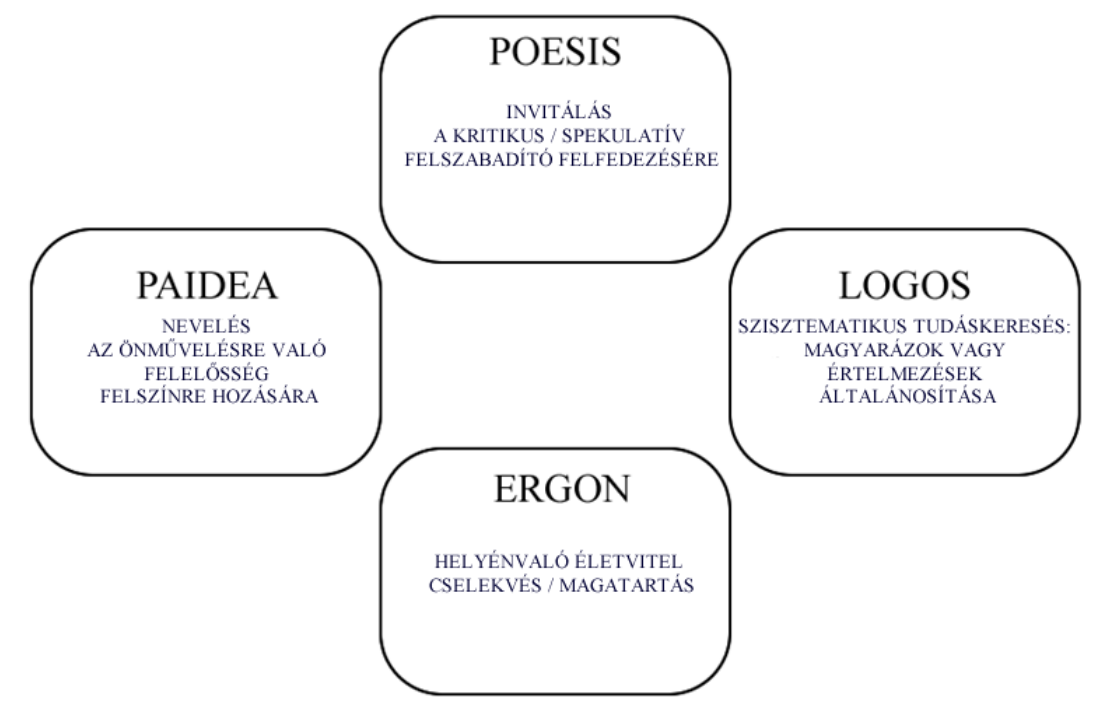

3. ábra. A tudományos gyakorlat klasszikus konstellációja. Poesis: kutatás, felfedezés és kritikus elmélkedés; Paidea: nevelés és tanulás; Logos: módszeres analitikus vizsgálat; Ergon: az ismeret életben és életvitelben történö gyakorlati alkalmazása. (Buttimer 1990, p. 9)-fordítás tölem.

Az akadémiai gyakorlat klasszikus konstellációi szerint négy különbözö szereptípus köré rendezi Buttimer a geográfusok szerepét. Ezeket nézzük meg kicsit részletesebben.

A poesis szerepe felfedezésre invitál, kritikus és felszabadító egyszerre. A kifejezés eredeti jelentése között is fellelhető olyan magyarázat, mely valami előállítását, előkészítését, létrehozását jelzi úgy, hogy a folyamat során mindez megfelel valamiféle szigorú szabálynak is. Az eredmény aztán önmagán is túlmutató lesz, születését követően pedig tartósan megmarad, nem alkalmi szülemény, hanem tartósnak ígérkező alkotás. Olyan - főként diszkurzív tevékenységből származó - produktumra utalhat, amely „a földrajz filozófiai kérdéseivel, fejlődéstörténetével és országok vagy tájegységek szépirodalmi igényü leírásával foglalkozó müvekben jelennek meg.” (Cséfalvay 1990, p. 55.)

A logos kicsit más szemlétet mutat. A szisztematikus tudást képviseli, a kutatásban az általánosítás, értelmezés és magyarázat együttesével, lényegében az analitikus kutatások tartoznak ide. Jellemző módon ez is szabályok, alapelvek és törvényszerüségek mentén halad, egyes értelmezésekben az önálló univerzum létrehozója és irányítója. A kimondott szó, a diskurzus és a gondolat fogalmaival összeforrott filozófiai jelentése a verbális (narratív) szerepkör túlsúlyára utal. ${ }^{61}$

Az ergon a helyénvaló viselkedés szempontja. A viselkedésé, az ügyes, jól formált cselekvésé, amely Homérosznál a müthosz alapvető ellentéte, a müthosz-é, amely az ügyes és jól formált elbeszélést formálja meg. ${ }^{62}$ Az ergon olyan, mint a szemnek a látás, a kabátnak a melegítés, a manifesztálódó cselekvés. Ha pedig a cselekvés egy tárgyra mutat, akkor az 
ergon maga a tárgyiasult mű lesz. ${ }^{63}$ (Steiger 2009, p. 11.) A földrajz esetében ez „,a konkrét környezeti és társadalmi problémák megoldásában való részvétel.” (Cséfalvay 1990, p. 55.)

A paidea az önképzés érdekében történő tudás kicsalogatása, a liberális oktatás napvilágra hozása, konkrétabban itt a „földrajz tanításával kapcsolatos szerepekre utal” (Cséfalvay 1990, p. 55., illetve vö. Buttimer 1990, p. 8.). A fogalmat filozófiai kontextusban az antikvitás humanizmusaként is értelmezték már, de leginkább elfogadott értelmezése a régi görögöknél használt, a testi és szellemi nevelés harmonikus egységét meghatározó jelentése. ${ }^{64}$ Egyértelmüen a tanítás tárgyára, az ismeretek összességére irányuló fogalom, amely jelentéstartalma összeforr a hosszas, fáradtságos folyamatot, képzést kifejező tevékenységi formákkal. ${ }^{65}$ (Markó 1994, p. 22.)

A négy szakmai szerepkörhöz két különböző szemléletmódot rendelhetünk: az insider és az outsider nézöpontját (vö. Buttimer 1999, p. 108). Ezek azonban nem harmonizálnak, inkább konfliktusos, egymással oppozícióban álló nézőpontpár. Az insider a térben élő laikus perspektívája, a legtisztább, leginkább organikus belső nézőpont. Nem tekinthető szakmainak, viszont az általuk megfogalmazott kérdések kiemelt célterületei - a bevezetőben említett közföldrajznak. Ezzel szemben az outsider egy másfajta nézőponttal rendelkező actora az eseményeknek, az insiderhez képest ő képviseli a szakmai szerepkört. Az outsider: a teret kívülről figyelni képes tervező perspektívája, olyan nézőpont, amely felismeri, elkülöníti és értelmezi a térben zajló folyamatokat. A figyelő szerep aktívvá is válhat, ha a háborút követő újjáépítési lázra, annak társadalmi-ideológiai lendületére gondolunk. Mind nyugati, mind keleti relációban találunk szép számmal lelkes actorait a feladatnak. A nézőpontok azonban nem csak az észlelés eltérő perspektíváit mutatják, hanem a különböző szintü problémaérzékenységre is utalnak. (Cséfalvay 1990, pp. 148-149.) Ez utóbbiról a későbbi fejezetekben még szó lesz. Most azonban - az elméleti bevezetőt követően - tekintsük át az egyes „forradalmi stációkat”, hogy az első diskurzusbéli kapcsolódásra még a fejezet vége előtt kísérletet tehessünk.

\section{Forradalmi stációk, és egy újabb diskurzusszint}

\section{Kvantitatív forradalom, mechanikus-formalizmus}

A háborút követően, az addig tisztán kvantitatív jelleg már megingott, és az uralkodó paradigma a mechanikus-formalizmus lett. Egyre több hangsúlyt kapott a tér elrendeződésének vizsgálata, amit az „outsider”-ek, a (geográfus-) tervezők az állami területfejlesztési politika támogatásán keresztül élvezhettek is. A földrajz külső szemlélőként tekintett a térre, és ebben a miliőben kereste annak optimális elrendezését, és az ember helyét 
ebben az új elrendeződésben. A narratív és diszkurzív kutatási irányok együtteséről beszélhetünk, melyet az outsider actorok háború utáni újjáépítés miatti presztízs növekedése is magyarázhat. Minden esetre a logos és az ergon, mintegy a szisztematikus tudás és az értelmes, szabályok szerinti cselekvés együtthatásaként érvényesül.

\section{Szociológiai irányok, kontextualista-mechanika}

A hatvanas-hetvenes évek szociologizáló irányzata a kontextualista-mechanika paradigmája felé fordul, így a szociálgeográfia lesz a megfelelő irányzat ahhoz, hogy a szüken vett élettér vizsgálatának térbeli aspektusait kutassa. A kvantitatív geográfia makroszintű elemzései helyett emberközpontú földrajz fogalmazódik meg, és ennek a szociálgeográfusok eleget is tudtak tenni. Már nem az volt a lényeges, „hogy miként müködik a térbeli világ, hanem az, hogy miként élünk ebben a világban.” (p. 43.) Ez a fajta elfordulás az első határozott lépés volt a kvantitatív normáktól az antropocentrikus világkép újjászületése felé. ${ }^{66} \mathrm{~A}$ változás kiteljesedéséből aztán számos geográfiai irányzat született és hatásukat máig éreztetik is. ${ }^{67} \mathrm{Az}$ ergon diszkurzív szerepköre a gyakorlati cselekvést hangsúlyozza, a kutatások publikációs metódusa a tényszerüség elveire épít, ami már a cselekvés mögöttes tartalmát nem képes értelmezni. A diszkurzivitás iránya megmarad a következő stációra is, de a poesis-szel kiegészülő szerepkör már egy narratív irányvonal erősödését jelzi. Ezeknek az irányzatoknak a fő vizsgálati területe „,a térbeli magatartás térbeli környezet” viszonyrendszere, s bár az ember volt a középpontban, mégsem kerülhetett a helyére. A valódi fordulat így a behavioristákra várt, akik beemelték az észlelést, az ember kognitív képességét ebbe a rendszerbe: „térbeli magatartás - ember - térbeli környezet”. (p. 50.)

\section{Behaviorista forradalom, kontextualizmus}

A behaviorista forradalom a nyolcvanas évekre érik be. Paradigma konstellációja az identitás kutatása felé fordul, megadva a földrajzi skála léptékét, amelyben vizsgálódnunk lehet. A kognitív folyamatok kutatása ebben a földrajzban fontosabb, mint a tényleges térbeli folyamatok vizsgálata.” (Cséfalvay 1990, p. 52.) A kontextualizmus uralkodóvá válása az ergon és a poesis szerepek dominánssá válását is hozza. A poesis megjelenése diszkurzív jellegü publikációs metódusokat eredményez. Pragmatikus jellege miatt a gyakorlati megvalósítás mikéntjére, a tágabb értelemben vett rendező elvre koncentráló irányzat. ${ }^{68} \mathrm{~A}$ térbeli kognitív folyamatokat belső, agyi reprezentációk felé tereli, miközben szinte teljesen mellőzi azt az axiómát, amit az eukleidészi és newtoni térfelfogás addig a geográfia rendelkezésére bocsájtott. Az outsider szerep a behavioristáknál végképp megszakad, és nem 
csak azért mert „feladják a hüvös objektivitás mítoszát” (p. 58.), de azért is, mert rájönnek, a bennünket körülvevő információk (nevezzük földrajzi információknak, bármi legyen is az most) csak az észlelő szubjektumán keresztül értelmezhetők. A publikációs metódus, bármennyire is mechanikus vagy kontextualista alapokra épül, narratív diszkurzivitással bíró lesz majd, de ez már a következő diskurzusszint, hipotézisem szerint egy új paradigma előszele, a kibernetikus paradigmáé, kitárva a kaput az információkezelés forradalma előtt.

\section{Információkezelés forradalma, a kibernetika paradigmája}

Cséfalvay szerint a behaviorista forradalom már akkor is sikereket ért volna el, ha nem tesz mást, mint befejezi „a közel negyven éve tartó folyamatot” (p. 59.), és végre egymásra találnak a laikusok és a szakemberek. ${ }^{69}$ Nos, ennél azért jóval több is történt. Az említett idézet óta két évtized telt el, és amit a szociológiai irányzatok előkészítettek, a behavioristák kiteljesítettek, mára úgy tünik beérett. A geográfiában az antropocentrikus perspektívák újraéledésének lehetünk tanúi, amelyhez narratív diszkurzivitás társul. A kibernetika által biztosított valós és virtuális miliő speciális szereppárokat követel majd. A dolgozatomban megfogalmazott tézisek mindegyike erre az új problémakörre, erre a formálódó új forradalmi irányzatra irányul. Hipotézisem szerint, ahogy azt a fejezet bevezetőjében már megfogalmaztam, az információs társadalom a társadalmi-evolúció fejlődési szakaszának jelenleg meghatározó, de egyáltalán nem végleges stádiuma. Az információs kor társadalmi formátumának a szerepe, jelentősége abban mutatkozik meg, hogy kijelöli a posztindusztriális társadalmak gondolati fejlődésének mintázatát, meghatározva azok technológiai aspektusú interdependenciáját. Ez lesz az a fajta technológiai-társadalmi mutualizmus, amely rámutat az infokommunikációs technológia és az emberi gondolkodás genetikai párhuzamaira. Mindennek akkor lesz jelentősége, ha a kognitív észlelés és a hálózatok szerveződésének logikája módszertanként testet ölt a konnektivizmus oktatási paradigmájában. $^{70}$

A fejezet tér és hely narratíváinak tipológiai kísérlete előkészítette az információs társadalom földrajzi aspektusú diskurzusát, melyet a következő fejezet tárgyal. Az alábbi ábra a paradigma illesztésének első stációja volt (4. ábra), még 2008-ban a tuniszi geográfus világkonferencián. Itt még kérdőjelekkel jelöltem a kérdéses funkciókat. Az értekezés végére eltünnek a kérdőjelek, és a századelő aktuális paradigmája a kibernetika lesz, melyet a geográfusok munkáinak is egyre inkább tükröznie kell majd. 


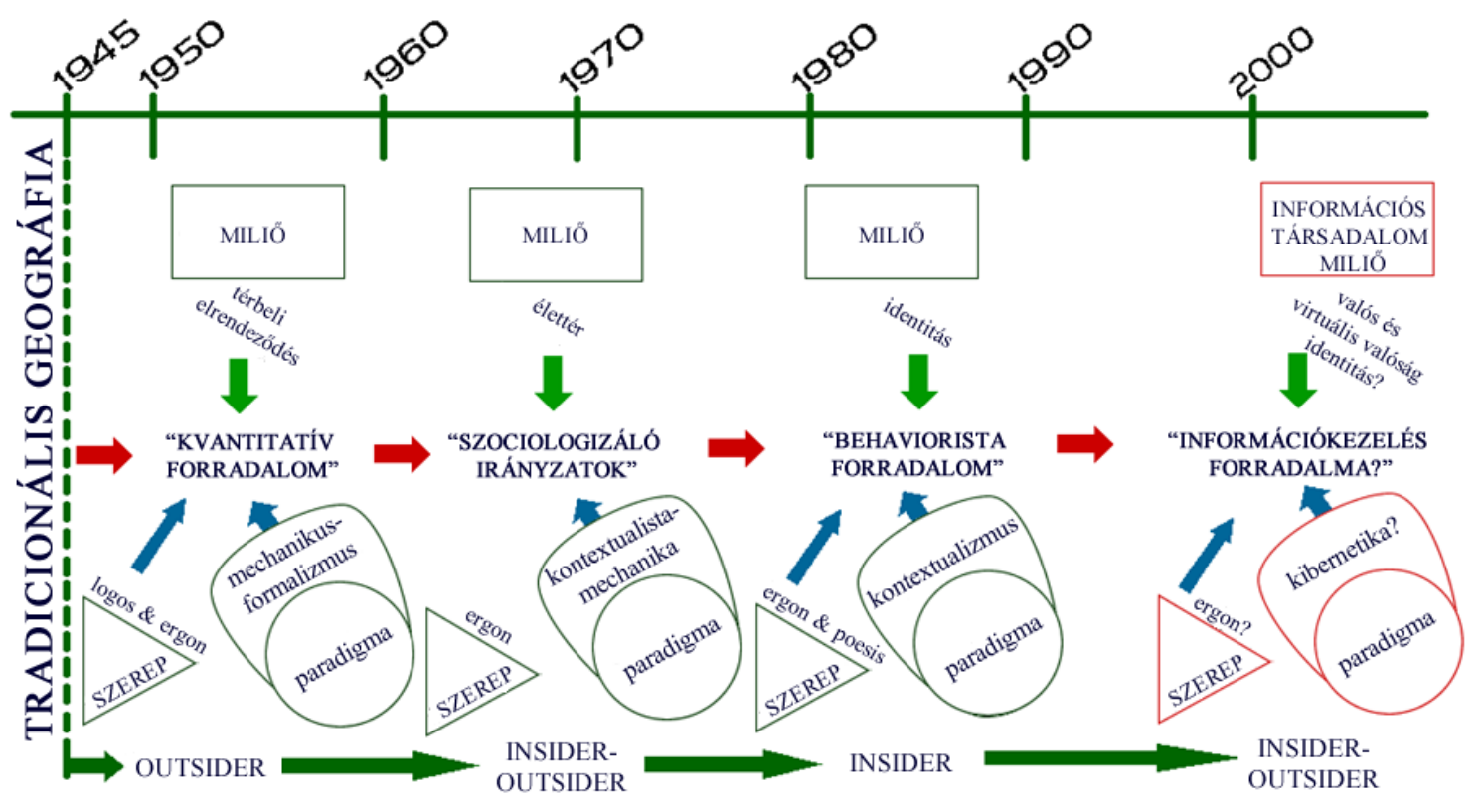

4. ábra. Forradalomról forradalomra, a földrajzi gondolkodás fejlödésének legújabb stációja (Cséfalvay 1990, Sinka 2008, a szerző kiegészitésével) ${ }^{71}$

\section{AZ INFORMÁCIÓS TÁRSADALOM FÖLDRAJZI DISKURZUSA - TÁRSADALOMTUDOMÁNYI DISKURZUSSZINT}

\section{A diskurzus előkészítése}

A gondolatmenet elindításához nagyban hozzájárult az a tény, hogy tanulmányaim egyik meghatározó pillanatában megismerkedtem Mészáros Rezső Kibertér c. (2003) munkájával. ${ }^{72}$ A könyv, amely akkor még témáját tekintve igencsak újdonságnak számított a magyar geográfusok között, kitárta előttem nem csak egy témához kötődő szakirodalom kapuját, de annak a lehetőségét, reményét is, hogy az információs társadalom kutatása egy geográfus számára is tartogat számos izgalmas területet. A kezdeti, korai információs társadalmat elemző kutatásokhoz csatlakozó vizsgálódásaimat ${ }^{73}$ (Sinka 2004, 2005, 2006b) hamar felváltotta a kapuk keresése (Sinka 2005, 2006a, 2006c, 2006d, 2007a). Egyre több esetben kerültem szembe a valós és virtuális terek közötti átjárók, ablakok, kapuk kérdésével (Sinka 2006a, 2007a, 2009b). ${ }^{74}$ Az információs társadalom térbeli folyamatainak értelmezése, elemzése számos estben az eltérő terek közötti átjárhatóság, a hozzáférés, az egyéni 
azonosítás, a térbeli közösségek redundanciájának néhol markáns, más esetben elmosódott alakzatainak értelmezése felé terelt. Mindezek eredményeképp jutottam el a humán interfészrés $^{75}$ problémaköréhez, melyre magyarázatot már csak a modern oktatáselméletek megismerése, és az a napi empirikus vizsgálódás adott, amelyet az e-learning területén végeztem (Sinka 2007a, 2007b, 2008, 2009a, 2010). ${ }^{76}$ A Kibertér megismerése, szépirodalmi hasonlattal élve számomra olyan új világot nyitott, mint Pullman világhírü trilógiájában Esahcettr, a kés, amely olyan titokzatos és éles, hogy bármit át tud vágni, akár még ablakot is képes nyitni a világok (univerzumok) között. Úgy vélem, Æsahæettr-t már megtaláltuk, ideje használnunk. ${ }^{77}$ Már csak arra kell figyelnünk, hogy jól és jóra használjuk, hogy akkor és ott nyíljanak kapuk, ahol azokra szükség van, és ott és akkor lépjünk be, ha arra magunk is jogosultak vagyunk és feltétlenül szükségünk is van rá. ${ }^{78}$

A diskurzus tárgyalásakor előbb azonban egy rövid kitéröt is kell tennünk a behavioristák érintésével a wieneri csoportalakzatok, az észlelés és információkészletfelhalmozás társadalom-evolúciós kérdéskörét érintő elméletekben. A kitérő elvezet bennünket az információs társadalom, mint társadalmi forma létrejöttének, a kapcsolódó világkép (az előző fejezetben bőven volt erről szó) paradigmájának és a csoportméret (mint humán információhordozó adattár) és csoportmiliő kérdéseinek összefüggéséhez. Ennél a pontnál kibonthatjuk az információs társadalom diskurzus szintjeit, további kísérleteket tehetünk a tipológia területén, és közelebb kerülünk a technológia és a társadalom interdependenciájának mutualista szemléletű értelmezéséhez. Az utóbbi megfogalmazást, a társadalom technológiai függőségét talán az alábbi, a Castells trilógia harmadik kötetének, 2. fejezetéből vett, idézet világítja meg a legjobban:

„Az áramlások terének (I. kötet, 6. fejezet) új, uralkodó logikáját követve azokat a területeket, amelyek az információs kapitalizmus szemszögéből nem értékesek, s az éppen regnáló hatalom szemében politikailag nem érdekesek, kikerülik a gazdagság és az információ áramlásai, s végső soron meg vannak fosztva attól az alapvető technológiai infrastruktúrától, amely a mai világban lehetővé teszi, hogy kommunikáljunk, újításokat vezessünk be, termeljünk, fogyasszunk vagy akár csak éljünk.” (Castells 2007, p. 89.)

A cél természetesen nem lehet az, hogy a kölcsönös egymásrautaltság jó vagy rossz oldala felett pálcát törjünk, helyette ebben a fejezetben elökészítjük egy régi-új földrajzi irányzat, a konnektivizmus földrajzának tárgyalását, amelyhez a kognitív architektúrák és a hálózatok rejtett dimenzióin át vezet majd az út. Az előkészítő munka egy diskurzusszint lényegében, amely annak a miliőnek a leírását kívánja megadni, amelyben a szemlélők és az aktorok (különböző szakemberek, geográfusok, döntéshozók) megfogalmazhatják az aktuális paradigmához való viszonyukat. 


\section{Az antropocentrikus földrajz újjáéledése}

Az információs társadalom diskurzusának bevezetéséhez szükséges kitérőben elsőként a behavioristákat érintjük (Koffka ${ }^{79}$, Tolman ${ }^{80}$, Downs és Stea 2005abc) de csak mint említettem addig, amíg Wiener csoportszintjei értelmet kapnak a társadalom-evolúciós elméletekben. Mindez együtt: a környezet észlelése - az információkészlet csoportszintjei és a társadalmak tudásszintjén definiálható világkép hármas kontextusa, véleményem szerint eddig, ilyen összefüggésben még nem tárgyalt, egyéni összefüggésben próbálja megragadni az információs társadalom legbensőbb földrajzi folyamatait.

A kvantitatív szemlélethez képest a behavioristák emberközpontú földrajza új magyarázatokkal szolgált, melynek továbbélését, sőt erősödését később is tapasztalhatjuk. ${ }^{81}$ Az újabban megjelenő munkákban is találhatunk direkt utalásokat az emberközpontúságra (Buttimer 1990), az érzékelés és az észlelés technológiai kötődéseiről (Inkinen 2003, 2006, Kellerman 2006). Természetesen mindent nem lehet az észlelés, az érzékelés felöl megközelíteni és megmagyarázni, ez csupán egy új megközelítési mód volt a geográfia számára, és amelyhez az említett források is igen érzékenyen közelednek. Az informatikának köszönhetően azonban nem a múlt, nem is egy érdekes próbálkozás, hanem ma is élő vizsgálati terület maradt napjainkra. Annak ellenére történt/történik mindez, hogy eldobja a kvantitatív geográfia szilárd és megbízható keretét, ${ }^{82} \mathrm{~s}$ egy olykor alig tapintható közeg vizsgálatába kezd, a környezeti észlelés transzmisszióján keresztül próbál a geográfia számára is hasznosítható tudományos, és nem utolsó sorban, a gyakorlatban hasznosítható megállapításokat kreálni. Az észlelését követően az információkat egyéni sémák szerint dolgozzuk fel, aminek az eredményeképpen a környezetünkröl alkotott kép jóval szubjektívabb, lényegében egy kognitív térkép lesz. (vö. Tolman 1948, Lynch 1960, Kitchin és Freundschuh 2002, Downs és Stea 1970, 2005a, 2005b) A kognitív térképezés szakaszait Downs és Stea szerint a következő sorrendben határozhatjuk meg: észlelés (környezeti információk összegyüjtése) - tájékozódás - szimbolizáció - identifikáció, vagyis egy rekonstrukciós folyamat, amely minden egyes pillanatban zajlik. ${ }^{83}$ (Downs and Stea 1970, in. Cséfalvay 1990, p. 66.) A környezetészlelés modellje így egy - lényegében végtelenített körfolyamat lesz, amint azt az alábbi ábra mutatja. 


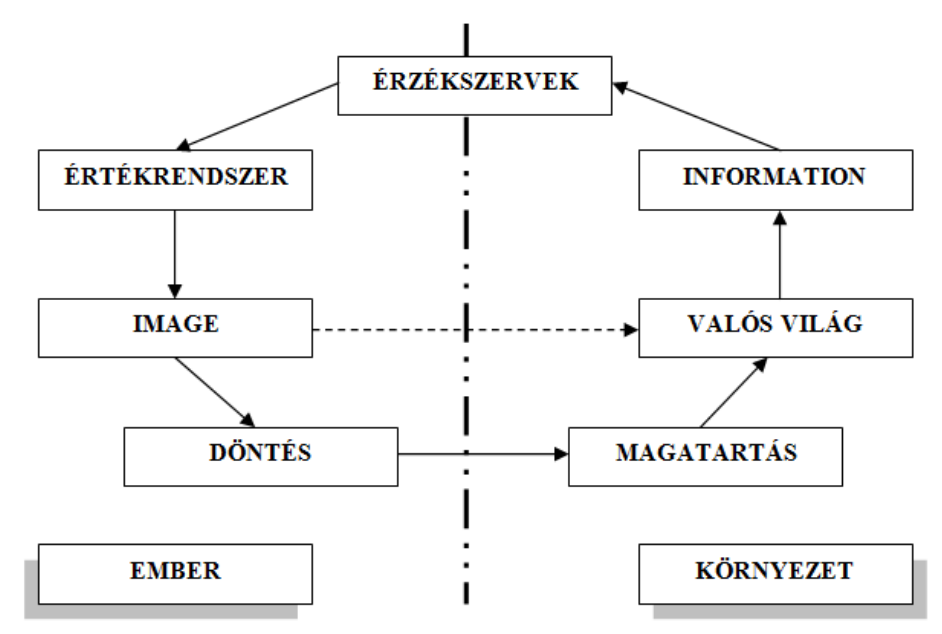

5. ábra. A környezetészlelés modellje a „,behaviorista forradalom” szerint (Downs nyomán innen:

Cséfalvay 1990, p. 51.)

Az igazsághoz hozzátartozik, hogy valójában nem zárt körfolyamatról, inkább egy algoritmikus ciklusról beszélünk, amely rendelkezik a futtatáshoz szükséges környezettel, elágazásokkal és visszacsatolással (cirkuláris kauzalitás); a zárt kör-ciklus, még ha körként is ábrázoljuk, lineáris, egyirányú folyamat, és nem magyarázhatná meg a közbenső hatásellenhatás és visszacsatolás lehetőségét (lineáris kauzalitás). Környezetünk észlelése, a földrajzi információk összegyüjtése valójában egyike a születésünk pillanatában kezdödő folyamatoknak, amely soha nem áll meg. ${ }^{84}$ Az észlelés folyamatát úgy kell elképzelnünk, amely során az érzékszerveink által felfogott a világ saját szubjektív szürőnkön halad át. A környezetünkből összegyüjtött információkból sajátos képet alkotunk a körülöttünk lévő világról, és bennünk kialakult világkép aztán meghatározza a döntéseinket, vagyis a térbeli magatartásunkat és tevékenységünket, végső soron pedig a tevékenységünk által pedig megváltoztatjuk a bennünket körülvevő környezetünket is. ${ }^{85} \mathrm{~A}$ folyamat tehát nem más, mint egy önmagában soha nem záródó ciklus. Nem körfolyamat, mert akkor nem tudnánk megmagyarázni a változásokat, a visszacsatolást. Naiv dolog lenne azt feltételezni, hogy a pszichológia beszivárgása a geográfiába csak a geográfusoknak okozott fejtörést, az ellenkező oldalon is akadt megoldandó kérdés a pszichológia és a viselkedés térbeli környezetének definiálása körül. Dows és Stea könyvében, a pszichológiai elmélkedők közül Koffka (1935) gondolatát idézik (melyet részben Tolman hatására alkotott), annak érdekében, hogy a pszichológusok különbséget tegyenek a földrajzi tér (mint abszolút tér) és a viselkedési környezet (mint szubjektív tér) között (Dows és Stea 2005c, p. 5.):

„A viselkedés egy, az azt szabályozó magatartási környezetben zajlik. A magatartási környezet két feltételhalmaztól függ, az egyik a földrajzi környezetben, a másik pedig az élő szervezetben rejlik. Azt is mondhatjuk, azonban, hogy a viselkedés egy földrajzi környezetben zajlik ... (1) Mivel a viselkedési 
környezet függ a földrajzitól, állításunk a viselkedést egy közvetett, mintsem egy közvetlen okra vezeti vissza ... (2) az állati viselkedés eredményei nemcsak annak viselkedési, hanem földrajzi környezetétől is függnek. ... A földrajzi - és nem csak a viselkedési - környezetet minden viselkedés megváltoztatja.” (Koffka 1935, p. 31, in.: Dows és Stea 2005c, p. 5.) - fordítás tőlem. ${ }^{86}$

A földrajzi környezet érzékelése tehát meglehetösen összetett folyamat abban az értelemben, hogy nem csupán mi érzékeljük a környezetünket, de viselkedésünk visszahat és megváltoztatja a körülöttünk lévő környezetet, ahogy erről már esett szó. Nem mindegy azonban, hogy ebben a kölcsönhatásban mennyien is vesznek ténylegesen részt. A földrajzi környezetünkről kialakitott képet éppen ezért nem csak az érzékelés maga határozza meg, hanem az is, hogy hányan érzékelik, értelmezik az adott teret és arról milyen világkép alakul ki a közösség számára. Éppen ezért nem az egyéni, hanem a csoport észlelése válik dominánssá. A környezetről alkotott kép egy közösség terméke lesz. Az egyének által összegyüjtött és értékelt információk pedig a közösség egyes csoportjai által összeadódnak, a társadalom egésze egyetlen nagy információközösséget alkot. ${ }^{87}$ Ez a kollektív tudat ${ }^{88}$ legprimitívebb formája, amely aztán az etatizmus fokától függően fejlettebb formákat is elérhet, illetve önmagát az irányító hatalom szolgálatába állítva (vagyis az egyéni információkészlet megosztása által) dönthet az elosztás formájáról, mennyiségi paramétereiről. Az első fejezetben még csak részlegesen említett idézetben Wiener egyértelmüen összefoglalja az egyén, mint entitás útján felhalmozott információkészlet és a csoport nagysága közötti koherenciát:

\footnotetext{
„Jelen könyv egyik tanulsága az, hogy bármely szervezetet ebben a tevékenységében az információ megszerzésére, felhasználására, tárolására és továbbítására szolgáló eszközök birtoklása tart össze. Olyan társadalomban, amely túl nagy ahhoz, hogy tagjai közvetlenül érintkezhessenek egymással, ezek az eszközök a sajtó — mind a könyvkiadás, mind az újságkiadás —, a rádió, a telefonrendszer, a távíró, a posta, a színház, a mozi, az iskolák és az egyház.” (Wiener 1974, p. 165.)
}

\section{A közösség addig terjed, ameddig az információ terjed}

Az infokommunikációs eszközök földrajzi gondolkodásunkra gyakorolt hatásának vizsgálatában először általánosan, a társadalmak információkészletének felhalmozásával foglalkozunk, annak érdekében, hogy a koherens közösségek létszáma (mint az információközösség tudati hordozói, a társadalmi hálózat elemeinek csoportja) és az aktuális világkép (mint a környezetértelmezés társadalmi paradigmája) kapcsolatában milyen összefüggés fedezhető fel. Ennek a fejlődési vonalnak a bemutatásával a társadalom oldaláról egyszerübben jutunk el az információs társadalom megértéséhez, hogy aztán ebbe a „dobozban”, mint az információs kor miliőjében keressük az aktuális paradigma definícióját. 
Ez a „doboz”, mint látni fogjuk a legkevésbé sem lesz tisztán geometriai térfogalmak szerint értelmezhető miliő, de amit a behavioristák szemléletéből tanulhattunk, kiváló alapot ad majd a továbblépéshez. A címben közölt állítás szerint a közösségek méretét, kiterjedését, morfológiai jellemzőit az információ terjedésének határai határozzák meg. Lényegében ameddig képesek a közösség tagjai az információkészletük átadására, addig a közösség létezhet. Az ember fizikai és értelmi evolúciója során mind nagyobb és nagyobb területeket foglalt el, s ezeken a területeken egyre nagyobb közösségeket alkotott, vagyis a népességszám növekedésével növekedett a földrajzi térből elfoglalt terület mérete is. Z. Karvalics László könyvének egyik, Út az információ-központú világképig című alfejezetében arról beszél, hogy a történelem egyes korszakaihoz „sajátos világkép-princípiumok (alapelvek)” rendelhetők. (Z. Karvalics 2002, pp. 95-96.) Az ennek megfelelő négy társadalomtörténeti szakaszról közölt táblázata megfeleltethető az egyes társadalmak (információközösségek) által ismert, felhasznált és birtokba vett „térszeleteknek”. A létrejött világképeket az alábbi 2. táblázat igyekszik összefoglalni, melyből kitünik, hogy az egyes korok által megismerhető földrajzi környezet nagysága, kiterjedése szorosan összefügg az adott társadalmat alkotó, a társadalmi térben szerveződő közösség tagjainak számával. Ez azt is jelenti, hogy az abszolút térben szerveződő populáció-csoportok és azok eloszlása (az őket körülölelő földrajzi környezetben) meghatározza, milyen világképpel rendelkezik az adott csoport, ami egyértelmű természeti földrajzi determinizmus. ${ }^{89} \mathrm{Ez}$ akár fordítva is igaz lehet. Egy fejlettebb társadalomban szerveződő kisebb közösség világképe jelentősen eltérhet az átlagtól, attól függetlenül, milyen intenzitással hat vissza környezetére, s ez az eltérés jellemzően térbeli elszigeteltség is párosulhat. $^{90}$

\begin{tabular}{|l|l|l|}
\hline Társadalmi forma & Világkép & $\begin{array}{l}\text { Közösségi képlet } \\
\text { (tagok száma tól-ig) }\end{array}$ \\
\hline $\begin{array}{l}\text { Halász - vadász - gyüjtögető } \\
\text { társadalom }\end{array}$ & Statikus világkép & $\begin{array}{l}\text { Horda (25-50) } \\
\text { Nagycsaládok csoportja (50-150) }\end{array}$ \\
\hline Földművelö társadalom & Dinamikus világkép & $\begin{array}{l}\text { Falusi közösségek (150-8000) } \\
\text { Város/városszövetségi (4000-4 millió) }\end{array}$ \\
\hline Ipari társadalom & Energia-centrikus világkép & $\begin{array}{l}\text { Nemzeti (-60 millió) } \\
\text { Nemzeti/regionális (8 millió - 2 milliárd) }\end{array}$ \\
\hline Információs társadalom & $\begin{array}{l}\text { Információ-centrikus } \\
\text { világkép }\end{array}$ & $\begin{array}{l}\text { Nemzeti/multiregionális } \\
\text { (800 millió - 4 milliárd) }\end{array}$ \\
\hline Tudástársadalom* globális (???)
\end{tabular}

2. táblázat. Korok, társadalmak, világképek - (Z. Karvalics 2002, p. 96., *kiegészítés tőlem) 
A populáció-csoportok (állandó vagy ad hoc) abszolút térbeli alakzatait fizikai oldalról az információs hálózatok fizikai és virtuális adottságai ${ }^{92}$ határozzák meg, ami technológiai determinizmus is egyben. Wiener egyik, részben már idézett gondolata illik ide (Wiener 1974, p. 165.):

„... a kicsi, szorosan összetartozó közösségek homeosztázisának a mértéke igen jelentős: és ez így van, akár civilizált országban magas műveltségű közösségekről, akár primitív vadak falvairól van szó. Bármily különösnek, sőt visszataszítónak találunk sok barbár szokást, ezeknek általában megvan a nagyon határozott homeosztatikus értéke; az antropológusok részben ezeknek a magyarázatával foglalkoznak.” (p. 165.)

Megjegyzem, a közösségen belül később meghatározó lesz az, hogy a populáción belül hányan rendelkeznek megfelelő interfésszel (human interface vs. human interface gap) annak érdekében, hogy a csoport belső információstruktúráját képesek legyenek maguk számára, véreredményben pedig kölcsönösen kihasználni. ${ }^{93}$ Erre utal Z. Karvalics Wiener munkáját elemző dolgozatából idézett részlet is:

„A közösségméret megnövekedése nyomán szükségessé vált információs kapcsolatokat biztosító rendszerek a közösség egészének szintjén anti-homeosztatikus hatást válthatnak ki, ám amennyiben a kisebb közösségi alakzatoknak módjukban áll az új eszközt, eljárást, intézményt saját határaikon belül működtetni, alacsonyabb szinten homeosztatikus müködésmódokat tudnak generálni a változatlan közösséglétszám mellett megnövelt műveleti gyorsasággal vagy hatékonysággal.” (Z. Karvalics 1999, p. 51.)

Wiener elméletének elvitathatatlan erénye, hogy ő „az első, aki megkísérli feltérképezni a közösségek puszta méretnagyság-növekedéséből levezetett információs változásainak méretnagyságát.” (Z. Karvalics 1999, p. 50.) Lényegében arról van szó, hogy a csoportnövekedése (jelentékeny populációnövekedésről beszélünk ez esetben) miatt az egyénnek önállóan, vagy (kisebb vagy elemi) csoport szinten rendelkeznie kell olyan technikákkal, metódusokkal, amelyekkel képes a megváltozott műveleti eljárásokhoz alkalmazkodni. ${ }^{94} \mathrm{~A}$ csoportok növekedésével együtt növekvö homeosztázis és az azt fenntartó, paradox módon ellene ható, anti-homeosztázist generáló eszközrendszer kapcsolata miatt van jelentősége említésének. A humán interfész megléte vagy nem léte ugyanis a csoport kohézióját, közvetve az egész közösség egységét veszélyezteti. ${ }^{95}$ A társadalmakat, közösséget összetartó homeosztázis lényegében az információközösség tudatán alapul, amely gyakorta területi, térbeli egységként is manifesztálódik. A gondolatmenet elvihet bennünket a nemzetállamok lehatárolásának kérdésköréhez, kapcsolódva olyan geográfiai kutatásokhoz, amelyek a nemzet és az állam területi egységét, a határok igazgatási, természeti földrajzi, antropológiai, gazdasági vagy egyéb szempontú értelmezését célozzák meg. A korán sem teljes 
felsoroláshoz további adalékkal szolgálhatna a társadalmi (és nemzeti identitásbeli) vagy kisebb, például régiók, kistérségek információközösségen alapuló homeosztázisának geográfiai célú elemzése. Az elemzések épülhetnének a korábbi információs társadalom kutatások eredményeire, illetve számos kommunikáció földrajzi kutatásba beilleszthetők lehetnek az itt megfogalmazott tézisek és eredmények. Az IKT geográfiai aspektusú kutatására egyre nagyobb lenne az igény, melyet Wiener kijelentése is indokol, ugyanis így folytatja:

„Csak a nagy közösségben, ahol a mihaszna grófokat megvédi vagyonuk az éhségtől, visszavonultságuk és névtelenségük a közvéleménytöl, a sajtótörvény és a hírközlő eszközök birtoklása a személyes kritikától, csak ott érheti el a gátlástalanság legmagasabb fokát. A társadalomban megtalálható antihomeosztatikus tényezők közül a hírközlő eszközök ellenőrzése a legeredményesebb és a legfontosabb.” (p. 165.)

A hírközlő eszközök fontosságának kiemelése lényeges mondat, mert már Wiener is a társadalom infokommunikációs (írott és elektronikus sajtó, távközlési) hálózatait állítja a középpontba, mint a homeosztázis megőrzéséért leginkább felelős, másrészről pedig, paradox módon annak szétzúzásáért is okolható eszközrendszert. Annak ellenére jelenti ki ezt, hogy a legkisebb közösségtől a legnagyobbig az információkezelés metodikáját (vö. digitális írástudás), annak kapcsolati rendszerét (hálózatosodás), és az elosztó rendszereket (konnektivista paradigma centrumok: könyvtárak, oktatási intézmények), mint a homeosztázis létrejöttének és tartós meglétének alapvető szükségletét definiálja:

„... bármely szervezetet ebben a tevékenységében az információ megszerzésére, felhasználására, tárolására és továbbítására szolgáló eszközök birtoklása tart össze. Olyan társadalomban, amely túl nagy ahhoz, hogy tagjai közvetlenül érintkezhessenek egymással, ezek az eszközök a sajtó - mind a könyvkiadás, mind az újságkiadás — - a rádió, a telefonrendszer, a távíró, a posta, a színház, a mozi. az iskolák és az egyház.” (p. 165.)

Wiener alaptétele szerint „,a közösség csak addig terjed, ameddig az információ átvitel terjed”, ami a globális információs vagy tudástársadalmakban nem jelent feltétlen és kizárólagosan face to face (f2f) kapcsolatot, hanem az IKT eszközöknek köszönhetően addig terjed ameddig a társadalmi tér terjed. Wiener alaptételével egyetértve úgy vélem, a földrajzi gondolkodás fejlettségét alapvetően meghatározza, hogy mekkora az adott populáció-csoport (tagjainak száma), a csoport által elfoglalt (abszolút és relatív) tér mérete, valamint, hogy milyen a csoporton belüli és a csoportok közötti információkezelési technika formájametódusa. A fentebb közölt táblázat utolsó sorában eredetileg csak az információs társadalom és annak információcentrikus világképe volt. Miután elolvastam Z. Karvalics László, Az 
információs társadalom keresése c. könyvét, szinte azonnal kiegészítettem a tudástársadalom, és annak tudáscentrikus világképének rubrikáival, analóg módon meghatározva a közösségi képlet infoplanetáris léptékét. Az ok egyszerü volt: 2003 novemberében elfogadták a Magyar Információs Társadalom Stratégiát (MITS 2003), amely nem csak számomra, de az ország valamennyi információs társadalommal foglalkozó kutatói, döntéshozói és területfejlesztési actorai számára egyaránt alapdokumentummá vált. Bár politikai dokumentum volt, és az operatív elemek csak érintőlegesen (esetenként ad hoc) kerültek kidolgozásra, a hozzá kapcsolódó gazdaság- és társadalomfejlesztési programok nemzetközi szinten is érdeklődést váltottak ki. (Sinka 2005, 2006) Annak ellenére, hogy lendületét vesztette, majd lassan eltünt a politikai süllyesztőben, máig érezhető hatása miatt sokan nosztalgiával gondolnak rá. „Mi lett volna, ha még ma is tart?” Ezt valószínüleg nem tudjuk meg, annyi azonban biztos, hogy a központi stratégiához kapcsolható előkészítő és arra épülő tanulmányok, kutatások szinte egyöntetűen máris az információs társadalmat követő tudástársadalmaktól voltak hangosak. ${ }^{96}$

Visszatérve az előző gondolathoz: az információs társadalom, mint társadalmi forma, és mint térbeli alakzat azonban addig elé (a MITS színre lépése előtt) nem volt a geográfiai kutatások központi témája, így térbeliségét, a benne zajló társadalmi folyamatokat megragadni, dinamikájukat leírni csak a témával foglalkozó társdiszciplínák és néhány külföldi geográfus munkáján keresztül volt lehetséges. ${ }^{97}$ Úgy tünik azonban, hogy „a mechanikus, majd energiaközpontú világképet felváltó információközpontú világkép valóban alkalmas arra, hogy maga köré rendezze a keresztkapcsolataikkal amúgyis mind alaktalanabbá váló tudományokat (Andréka - Németi 1988).” (in. Z. Karvalics 1995)

A geográfusoknak tehát ismét illik bünbe esni, hogy a vizsgált terület térbeli elrendeződését, a benne zajló jelenségek és folyamatok dinamikáját megismerhessék. Egy új kutatási terület persze még nem jelent feltétlenül paradigmaváltást, de a meglévő fogalomrendszer és tipológia kibővítését akkor is megköveteli. A földrajzi paradigmák fejlödéséről már esett szó az előző fejezetekben, s bár a geográfia is kialakította fejlödése során a maga fogalomrendszerét, most új kihívással kell szembenéznie: az információs társadalom földrajzi kutatásának megalapozásával. Az eredmény pedig, úgy tünik, hogy egy új paradigma születése lesz.

\section{A geográfiai diskurzus-alapozás, újabb tipológiai bevezető}

Peter Jackson ${ }^{98}$ egyik tanulmányának segítségével szeretném az információs társadalom geográfiai szemléletű diskurzusát felvezetni. A felvezetés az információs társadalom tipológiája felé tesz egy újabb lépést. Jackson Thinking Geographically (Geographical Association, Manchester 2006) című előadása alapján készült cikk a földrajzi gondolkodás 
ereje mellett érvel, „hangsúlyozva a diszciplína nyelvtanát (annak fogalmait és elméletét), valamint szókincsét (egy virtuálisan végtelen hosszú hely-név listát)." ${ }^{99}$ A legfontosabb geográfiai kulcs fogalmak, illetve fogalom párok Jackson szerint: a tér és hely, skála és kapcsolat, a közelség és távolság, és a relációs gondolkodás (Jackson 2006). ${ }^{100}$

A tér és hely természetének a kérdése régi vitája a geográfusoknak. A két kifejezés közötti jelentés meghatározása mindig is figyelmet igénylő tevékenység volt a szakmában. Egyes kutatók szerint „a hely egy humanizált tér”, egy absztrakt világ, amely az emberi lakóhelyek által jön létre, lényegében érzelmi kötődéssel és jelentéstartalommal felruházott valóság. ${ }^{101}$ Ezek a felruházott jelentéstartalmak kiválóan kifejeződnek a lokális, kistérségi, regionális vagy akár a nemzeti identitástudatban, amely régóta kedvelt területe a geográfiának. ${ }^{102}$ Az identifikáció kiemelt kérdéskör az információs társadalomban, bármely típusát is vesszük górcső alá: térbeli, hálózati, lokális, globális, web, személyes, virtuális, hogy csak a legszembetünőbbeket említsem. Mások ezzel szemben úgy vélik, hogy a fenti szemlélet idejemúlt, és a tér nem kevésbé konkrét, megalapozott és reális képződmény, mint a hely. ${ }^{103}$ Néhányan kutató e helyett egy jóval határozottabb utat kínál a kérdéskör megközelítéséhez, és az „idö-tér kompresszió” fogalmával írják le azt a folyamatot, amely egy újabb megközelítést kínál tér és hely értelmezésében, és amely eredményeként a világunk egyre kisebbé válik. A fogalom magyarázatát az egyre inkább begyürüző tőkebefektetések jelenthetik, amik technológiai, szociális, politikai és végül kulturális változásokat eredményeznek a világ szinte minden pontján. ${ }^{104}$ Egyes szociológusok odáig mennek, hogy ez az idő-tér kompresszió a hely sajátosságait, specifikációit gyökerestül megsemmisíti, végeredményképp egy hely-nélküli (placeless) planétát hozva létre. ${ }^{105}$ Megint mások vitatkoznak ezzel a borúlátó jövendöléssel a helyi megkülönböztető jegyek eróziójáról ${ }^{106}$ Ide Jackson beleérti Massey határozott véleményét a progresszív vagy globális térérzetröl, amelyeket porózus határok, belső összekapcsolódások jellemeznek fix identitások és áthatolhatatlan határok helyett. Masseynek és néhány kutatónak a hely sajátosságait azok az út(vonal)ak adják, amelyek összekapcsolják őket más helyekkel és idővel, nem pedig az emberek kijelentései egy időtlen és felbonthatatlan meggyökeresedésről egy sajátos lokalitáson belül. Ez Castells (2005) számára a hely végső paradoxonját jelenti: miszerint valamennyi hely kivételes és kapcsolódik más helyekhez.

A földrajzban a skálák (és a köztük fennálló kapcsolatok) igen fontos szerepet töltenek be. A geográfusok frekventáltan érdeklődnek a skála hierarchiák iránt, egészen a testközeli skáláktól a világméretűekig. Dolgoznak ezen kívül közbenső skálákkal is a várostól a régiókig, a nemzetitől a nemzetköziig. A geográfusok rendelkeznek a skálák közötti mozgás képességével, és mivel tudják értelmezni az egyes skálák léptékét és a köztük lévő kapcsolatokat, átjárhatóvá válnak számukra a legeltérőbb léptékủ térbeli folyamatok is. Ez a 
képesség segíti a geográfiát azokban a vizsgálatokban, amikor globális vállalatok döntéseinek hatását kell értelmezniük a különböző lokális szinteken.

Szomszédság és távolság kérdéskörénél ne feledkezzünk meg arról, hogy nem csak az jelent érzékelhető távolságot, amely fizikailag létezik, kilométerben mérhető, hanem a szociális és a képzelt távolságok is. Mára közhellyé vált, hogy a teret kitágítja a televízió, az internet, és a közelünkben érezzük a világot. ${ }^{107}$ A geográfusok az ilyen „távoliság” fogalmát azonban nem pusztán a távolság elkerülhetetlen következményeként, inkább társadalmilag megalkotott fogalomként értelmezik. A társadalmi és térbeli egyenlőtlenségeket jól demonstrálja az a tapasztalat, hogy sokszor jobban törődünk a „távoli idegenekkel”, mintsem, hogy azokkal az egyenlőtelenségekkel foglalkozzunk, amelyek szó szerint a küszöbünk előtt történnek. A városainkban zajló társadalmi egyenlőtlenségek terjedése (mérhetjük akár a gyermekszegénység, oktatási egyenlötlenség, élelmiszer bizonytalanság, vagy sok más egyéb mutató segítségével) szomorúan mutatja, mennyire nem törődünk az otthonunkhoz közeli eseményekkel.

A relációs gondolkodás, vagy kauzalitás, az ok okozati összefüggések feltárásának gondolatmenete Jackson szerint eltér a többitől. Ez utal arra a szempontra, amellyel mi gondolunk a különbözőségekre és az azonosságokra (megfogalmazódik ez a nemek, fajok és osztályok terminusában) szembeállítva a földrajzi énnel és másokkal. (Az egyik klasszikus szöveg a nagy földrajzi hovatartozásról Said Orientalismus c. tanulmánya.) Az egyes nézőpontok által publikált anyagok többet mondanak el a publikálóról magáról, mint a publikáció tárgyáról, tényéről (lásd narratív-diszkurzív publikációs metódusok). A geográfiának ezt a torz szemléletet kerülnie kell, nyomait is igyekezni kell eltüntetni. A legkedveltebb kutatási irány a központok vizsgálata, a centrum-periféria vizsgálatok, amikor a centrumok a perifériák költségén nőnek, híznak, mint ahogy észak jóléte dél kizsákmányolásán múlik. Ez az egyik klasszikus térbeli relációs kapcsolat, amit a geográfusok használnak, s ehhez hasonló ok-okozati térbeli összefüggések sorozata adja a térbeli folyamatok értelmezésének szerkezeti vázát.

\section{Bevezetés az információs társadalom földrajzi diskurzusába}

Z. Karvalics László (2007) egyik dolgozatának az Információs társadalom - mi az? Egy kifejezés jelentése, története és fogalomkörnyezete címet adta. A kérdés nem hiábavaló, mert a társadalom információs jelzővel való ellátása egyáltalán nem egyértelmű. Az információ minden történelmi szakaszban a társadalom aktuális világképének megformálásának kulcsfontosságú eszköze volt. Eszköz, de mert „az információ nem anyag és nem energia” (Wiener 1974, p. 129.), inkább rendszerépítő elemként, szervező metódusként értelmezhető, 
ezért „az információ az, ami a szervezett rendszerek kialakulását/kialakítását lehetővé teszi, és az információk segítségével lehet fenntartani, illetve növelni a szervezettségben megnyilvánuló rendet.” (Komenczi 2002) A megközelítés így szemantikai (tágabb értelemben társadalomtudományi) és nem annyira matematikai. A társadalomtudományi értelmezés érdekesebb is most, mert előre vetíti az információ tudásszervező és rendszerező képességét. „A tudást összefüggéseiben tekintett információként határozhatjuk meg, amiként a bölcsesség sem más, mint az életegész összefüggésébe illesztett tudás.”108 Az információs előtag tehát önmagában nem jelent magyarázatot a használatra, a társadalmak minden korban megkaphatták volna ezt a prepozíciót. A megoldást máshol kell keresni, mégpedig a hatvanas évek japán társadalomtudományi irodalmában. A kifejezés itt kapott életre, közelebbről nézve Kisho Kurokawa (építész) és Tadao Umesao (történész - antropológus) beszélgetései, illetve az azt követő, évtizedes publikációs dömpingben, amelyet a szigetország kutatói indítottak el. ${ }^{109}$ A kifejezés használatára megvan tehát a tudománytörténeti magyarázat, már csak a jelentéstartalmat kell röviden tisztázni. Ha az eddigi gondolatmenetet követjük, akkor a legegyszerübb magyarázatot a már tárgyalt társadalom-evolúciós vonal és az annak mentén fejlődő világképek adhatják meg. Az ipari társadalmakat követő ún. posztindusztriális társadalmi formaként megjelenő információs társadalom egy információközpontú világképet testesít meg. ${ }^{110}$ A fogalmak jelentéstartalma így keleten és nyugaton összecseng, a Japánban információs társadalomként aposztrofált új társadalmi-gazdasági miliőt az angolszász irodalom „posztindusztriális” illetve „fehérgalléros” forradalomként deklarálja. A posztindusztriális kifejezés egyébként zavaró is lehet, és további állandó magyarázatokat igényelne, hiszen ennél technokratább társadalmi alakzat egyetlen történelmi korban sem volt, mint a mai. A világkép szerinti megközelítésre utaló jelző magyarázata mindenképp egyszerübb, már csak azért is, mert a neomarxista kritikai iskola (Webster 2002) is azzal érvel, hogy az információs - tudás - hálózat - posztindusztriális vagy éppen a posztmodern elötagok félrevezetőek, és diszkontinuitást sugallnak. Egyetértek a neomarxisták gondolatmenetével, hogy az információs társadalom még mindig a tőkefelhalmozásra épülő kapitalista rendszer, éppen ezért a hangsúlyt máshová helyezem a vizsgálódásom során. Követve azt, a kortárs szociológiában elfogadott gondolatmenetet, amely szerint az információs társadalom elmélete elsődlegesen az információ és a közvetitö infokommunikációs technológiák társadalmi szerepével foglalkozik, a dolgozatomban kifejtett tézisek megvitatását is ennek szellemében követem.

Az iménti rövid fogalmi felvezetés nem helyettesítheti azt a társadalomtudományi, mélyrétegeket megmozgató, igen tekintélyes hazai és nemzetközi szakirodalmi hátteret, amely ezt a témakört részleteiben tárgyalja. A cél inkább, a történeti háttér felvillantása mellett, a fogalmi értelmezés nehézségeinek fellazítása volt. A szociológusok, történészek, filozófusok, 
építészek, közgazdászok, mérnökök, matematikusok és számos más szakmacsoport képviselői által „elökészített” terep egy felfedezésre váró területe volt a geográfusoknak. A nemzetközi közösség, ahol az információs társadalom hatása is gyorsabban jelentkezett, viszonylag hamarabb reagált, míg geográfusaink a hazai technológiai áttöréssel szinkronban, néhány éves csúszással jelentek meg első tanulmányaikkal. ${ }^{111}$

\section{Diskurzus szintek, problémafelvetés}

Napjaink tér- és társadalomdinamikájának vizsgálatakor a földrajztudomány interdiszciplinaritására talán nagyobb szükség van, mint valaha. Az információs társadalom földrajzi szemléletủ vizsgálata jelenleg Magyarországon, ha nem is negligált, de legalábbis egy szükebb szakmai kör érdeklődési területét tükrözi. A szakmai diskurzus azonban elindult, igaz ezt követően néhány év múlva kissé lendületét is vesztette. A leggyakrabban szociológiai, filozófiai és technológiai aspektusú megközelítések mellett az információs társadalom földrajza, új típusú metodikája, fogalomrendszere, tipológiája is megjelent a hazai szakirodalomban. A hazai geográfusok is igyekeztek definiálni a fizikai és a virtuális térben zajló folyamatokat, jelenségeket, megfogalmazni a geográfia viszonyát az információs társadalomhoz, mint kutatási területhez. Ahogy Mészáros idézi könyvében:

\footnotetext{
„Újfajta geográfia van kialakulóban... Már teljesen elért bennünket, és egy generáció múlva olyan drámai módon változtatja meg a földrajztudományról alkotott elképzelésünket, mint ahogyan Klaudiosz Ptolemaiosz kartográfiája óta semmi sem.” (Batty és Barr 1994, in. Mészáros 2003, p. 19.)
}

A térbeliség és a tipológia vizsgálata előtt érdemes az információs társadalom földrajzának fogalmi megközelítésére is koncentrálni. Több lehetőség is kínálkozik a csoportosítására. Frank Webster (Webster 2002, pp. 8-29.), fentebb már idézett müvében öt diszkurzus szintet jelölt meg: technológiai, közgazdasági, foglalkozási, térbeli és kulturális. ${ }^{112}$ Ezzel kapcsolatban Pintér Róbert szociológus doktori értekezésében megjegyzi, hogy talán nem ez a legrészletesebb felosztás, de „érdemes lehet már létező hagyományként felhasználni a további vizsgálódások kiindulópontjai gyanánt.” (Pintér 2004, p. 25.) A társadalomelméleti fogalomértelmezések közül most a Mészáros Rezső által megjelölt, a kibertérrel kapcsolatos társadalomelméleti csoportokat tekintjük át röviden (Mészáros 2003, pp. 52-55.), miközben a modernek és a posztmodernek nézőpontjai közé, ahol lehetséges beillesztem Webster diskurzus szintjeit is:

(1) Az utópista megközelítések empirikus alapokon, a technikai innovációk mindenhatóságát hangsúlyozzák. Ahogy a szerző is hangsúlyozza, nem elméleti, inkább érzelmi alapon szerveződő elméletekről beszélhetünk. Amiért mégsem szabad mellőzni 
ezeket a munkákat az leginkább az, hogy ,jövőbelátó” képességük olyan struktúrák létrejöttét sugallták, amelyeket a technológiai fejlődés idővel számos esetben igazolt. Mindamellett ezeket az utópista irányzatokat is csoportosíthatjuk: vannak, amelyek a technológia mindenek felettiségét (az egyéni képviseleti demokráciától a kibernetikus organizmusokig), míg mások épp annak az ellenkezőjét, a technológia emberiséget is elpusztító hatását emelik ki.

(2) A technikai determinizmus hívei az előzőekből táplálkoznak. Épp úgy, mint a természeti földrajzi determinizmus esetében, a szélsőséget képviselik. Az élet minden mozzanatát átszövő technika valóban markáns jelensége társadalmunknak, így nehéz kritikai diskurzust folytatni azzal a felfogással, amely szerint „a technika önálló, aktív, meghatározó, a kultúra és az ember énje pedig alárendelt, passzív és csak reagálni képes.” (p. 53.) Egyszerü kauzalitással állunk szemben, amikor a technokraták olyan társadalmi frakcióról beszélnek, amelyeket már/majd a kibertér alkot a magánélettől az üzleti és politikai rendszerekig. Webster vizsgálati hangsúlyeltolódásával (a technológiai attitüd jellegének változásával) egyetértve, ráadásul napjainkban mindezt testközelből is érzékelhetjük a hírekből és a webes közösségépítő és kollaborációs terek tömeges elterjedésén keresztül a technikai eszközök minden percünk részévé váltak.

(3) A társadalmi konstrukció elméletek azonban szembe mennek a technológiai szemlélettel, és inkább szociális determinizmusról beszélnek: a technika társadalmi konstrukció, így az a feletti uralom is a társadalom kezében van. Ez a gondolat nem csak egy egyszerü gordiuszi megoldás, hanem határozott társadalomelméleti iskola, amellyel egyetértve már idéztem Castells társadalomfejlődési (spirális) ciklusról írt gondolatát. Ebben a technológia még oly meghatározó szerepe ellenére is csak a lánc egyetlen szeme, de nem kivételezettebb, mint a többi. Ennek megfelelően a technológia közvetítésért is a társadalom, a kultúra és az oktatás tehető felelőssé, a kontroll és a felelősség társadalmi kézben marad. ${ }^{113}$

(4) A politikai gazdaságtani szemléletmód oldani kívánja a kapcsolatot a társadalom és a technika között, a hangsúlyt inkább a tőkemozgások, tőkeallokációk és a kibertér közötti összefüggésekre helyezi. Webster gazdasági és foglalkozásszerkezeti változásokat tárgyaló csoportjai is inkább kvalitatív kérdéseket feszegetnek: vajon az új típusú munkahelyek megjelenése, a régiek eltünése megváltoztatta-e a kapitalizmus logikáját vagy más mechanizmusok müködnek a háttérben. A hangsúlyeltolódás itt is érthető, ha arra a pénzügyi - gazdasági válságra gondolunk, amelyet a világ pénzügyi központjai és azok virtuális pénzügyi tranzakciói okoztak az elmúlt években. A globális pénzügyi rendszer hálózata elérte azt, amire sokan sokáig nem is gondolhattak, úgy képes véghezvinni lokális tőkefelhalmozást, befektetéseket, hogy az adott helyen valójában nem is jelenik meg, a tőke a virtualizált bankés tőzsderendszer keretein belül marad. ${ }^{114}$ Mindehhez a globális infokommunikációs hálózatot használja fel. 
(5) A posztmodernek zárják Mészáros Rezső társadalomkritikai felosztását. A fontosságuk elméleti szempontból ott van, hogy nem erodálnak egyetlen kritikai irányzatot sem a képletes sémák szintjére, hangoztatják - és nem csak a kibertér esetében - az értelmezések szabadságát, egyéni olvasatokat kínálnak és inkább hálózati kauzalitást feltételeznek a magyarázatok mögött. (vö. Castells 2005) A posztmodernek felfogása újrafogalmazza és újragondolja a világ megértését, érzékelését, s a tapasztalatszerzés alternatív formáit keresi. A modernitás oppozíciójaként megjelenő posztmodernek mellett ott találjuk a feministákat is. ${ }^{115} \mathrm{Az}$ említésük elsőre talán meglepőnek tűnik, de ha azokat a kutatási eredményeket is figyelembe vesszük, amelyek szerint a kibertérben, és tulajdonképp az egész társadalomban a nők alulprezentáltak, akkor érthető, hogy ez több mint érdekesség, ez nagyon is aktuális társadalmi probléma. Egyetlen példa az Amszterdami Digitális Város (1994) projekt kapcsán két évvel később készült felmérés, amelyben a város harmincötezer regisztrált lakosának csupán $15 \%$-a volt nő. ${ }^{116} \mathrm{~A}$ proaktív mozgalmat képviselö ${ }^{117}$ feministák célja éppen ezért a patriarchális társadalmi berendelkezéssel szemben, vagy azon belül a női szerepek újradefiniálása, egy nemileg kiegyensúlyozottabb világ érdekében. Amint azonban az említett felmérés is igazolta, a kibertérben sem történik más és jellemzően a valós társadalmi kép tükröződik. Ha az torz, akkor a másik is az.

Érdemes a posztmoderneket követően Webster kultúra és tér diskurzus szintjeiről még külön is beszélni. Az információs társadalom kultúrájának diskurzusa talán az egyik legszembetünőbb, de egyben az egyik legkevésbé mérhető dolog is. Azt látjuk, érezzük, tapasztaljuk, hogy a gazdasági globalizáció - sok más mellett - nem hagyja érintetlenül a klasszikus értelemben vett nemzeti kultúra értékeit sem. Erősödő interdependencia alakul ki a gazdaság és a média által közvetített kultúra között, melynek párája az információs korszak társadalmának meghatározó folyamataként csapódik le. (Webster 2002, p. 20-21., Sinka 2004, p. 194.) A média kulturális beágyazottsága egyre globálisabb képet mutat a kommunikációs technológiák miatt. Ahogy, követve Webster felvetését Pintér kifejti dolgozatában:

\footnotetext{
„Kérdés azonban, hogy hogyan, és mitől-miért változott meg a média kulturális beágyazottsága? Az információs társadalom kultúrájával foglalkozó elméletek olyan új globális kultúra megjelenését írják le, amit egyetemleges referencia-keretként használhat a média, mint kontextust. A legfontosabb, hogy az információs korszakban a kultúra kiemelt szerepbe kerül, a társadalmi viszonyok egyik meghatározójává válik. Ami benne van a médiában az a valóság, ami kívül reked, az pedig partvonalra szorul. [...] Az információs korszak hívószava a virtuális valóság, amely sokszor fontosabbá válik, mint maga a valóság, amiből építkezik.” (Pintér 2004, pp. 27-28.)
}

A térszerkezet átalakulásához kapcsolódó diskurzus - úgy vélem - a geográfusok számára a legizgalmasabb kutatási területet. Webster, aki szociológusként nem bocsátkozik az 
információs társadalom térszerkezetének elemzésébe, csupán azt emeli ki, hogy ez a diskurzus megkülönböztető figyelmet érdemel, a hangsúly pedig az információs hálózatok vizsgálatára helyezi. A hálózatok kapcsolatát felismerve a tér- és időbeli folyamatokra gyakorolt hatását hangsúlyozza. Különösen népszerü mutatóként említi az információs hálózatok hatására a társadalmi alakzatok tekintetében jelentkező tagoltságot. A tér és idő kapcsolatrendszerének tekintetében is Castells logikájára hivatkozik:

„Egy elterjedt elképzelés szerint az elektronikus szupesztrádák új irányt szabnak az információáramlásban (Castells, 1996), ami az idő/tér viszonyok gyökeres megváltozásához vezet. Egy 'hálózati társadalomban' az idő és a távolság okozta korlátok jelentősen enyhültek, hiszen a vállalatok és az egyének képesek világviszonylatban is hatékonyan intézni ügyeiket.” (Webster 2002, p. 17.) - fordítás tőlem. ${ }^{118}$

Amint látható, a társadalomtudományi irányzatok az információs társadalom vagy a kibertér tekintetében igen óvatosan közelítenek a térbeli fogalmakhoz. Tiszteletreméltó ez az óvatosság, s a szakmai körökben elfogadott releváns szociológiai tanulmányok nem is lépnek ezen túl. Diskurzusra hívják azonban a geográfusokat, kérdéseket provokálnak annak érdekében, hogy a tapintható társadalmi folyamatok térbeli dinamikájához magyarázatokat, értelmezési keretet kapjanak. Pintér a következő kérdéseket fogalmazza meg dolgozatában Webster szociológiai aspektusú tér diszkussziójához kapcsolódóan:

\footnotetext{
„Az elméleti megközelítés fő kérdései, hogy hogyan változik meg az emberek térbeli kötődése? Hálózati logikát követ-e a világ működése; létezik-e, kialakul-e globális társadalom? Mi ennek a hálózatnak a belső logikája: ki az, aki benne van és miért? Milyen társadalmi-gazdasági tőke kell a hálózatba való belépéshez és a bennmaradáshoz? Milyen a belső kapcsolatrendszer és mi a szerepe ebben az új információs kommunikációs technológiáknak?” (Pintér 2004, p. 27.).
}

A fejezet további részében az információs társadalom társadalomtudományi diskurzusát felváltja egy geográfiai szemléletű elemzés azzal a céllal, hogy tipológiai keretet biztosítsunk a térbeli gondolkodásunkat napjainkban meghatározó társadalmi környezetünknek, a miliőnek. A vizsgálódás során ki kell derülnie, milyen viszonyban van a kibertér az információs társadalom terével, miért lehetet a társadalomtudományi értelmezésekben a két fogalom szinonim, és az is, hogy milyen további térdimenziók állnak rendelkezésünkre, ha az euklidészi - newtoni 'kockában' és milyen, ha egy 'kvázi-plasztikus tér-felhőben' akarunk mozogni, és eljutni A-ból, B-be. 


\section{AZ INFORMÁCIÓS TÁRSADALOM FÖLDRAJZI DISKURZUSA - GEOGRÁFIAI DISKURZUSSZINT}

\section{Geográfiai elméletek diskurzus szintjei}

A társadalomtudományi diskurzusok analógiáját követve, a geográfiai értelmezések között is megtalálhatjuk a megfelelő megközelítési módokat, amelyek által újabb diskurzus szinteket kapcsolhatunk a korábbiakhoz. A földrajzi tér vizsgálata egyébként is mindig összefüggéseikben és a benne zajló jelenségek tükrében kerül elemezésre, ami lényegében eltérő diskurzus szintek szintézisét eredményezi. Az információs társadalom földrajzának tere is egy összetett folyamat-konstrukció terméke, egyes elemei stabilak, mások instabil jelleget mutatnak, időnként eltünnek, máskor vagy máshol pedig előbukkannak, azonban relatív térkonstrukciókként ritkán hordoznak az azt megelőzővel azonos (például morfológiai) jegyeket. Ez a dinamikus változás az egyik alapvető jellegzetességük, ami markánsan megkülönbözteti a többi térbeli alakzattól és koncepciótól. Ahhoz, hogy ezt megértsük, nézzük meg milyen értelmezési rétegekkel rendelkezik, azok miként viszonyulnak egymáshoz, létezik-e függőség az elrendeződésben, és milyen attribútumok alapján különülnek el a tipológiai rendszeren belül. A dolgozat eredeti célkitüzését nem szem elől tévesztve, a tér tipológiája és értelmezési kerete csupán az aktuális paradigma értelmezési keretének, a miliőnek a határvonalait kívánja kijelölni.

Az értelmezési keret miliőjének történeti meghatározottságát, fejlődési irányát kiválóan szemlélteti a Kellerman ${ }^{119}$ által készített ábra az információs társadalom előbukkanásának egyes fázisairól, az ún. inkubációs fázistól (a hatvanas-hetvenes évek információ-gazdag társadalmától) egészen az információ-domináns társadalomig, amely dominanciáját a Castells által definiált „kulturális meghatározottság” is szimbolizálja. ${ }^{120}$ Kellerman szerint az információs társadalom történetének harmadik nagy fázisa a 90-es évek végétől az ezredforduló elejéig tartó időszak, amelyet információ-domináns társadalomnak nevez.

\footnotetext{
„Az információ létrehozása, átadása és felhasználása egy, vagy inkább $a$ vezető gazdasági és társadalmi tevékenységgé vált, akár önmagában egy termékként, akár egy, az anyagi termékek létrehozásához vagy felhasználásához vezető szolgáltatásként. Mint ilyen, három további jellemzővel bővült az információs társadalom: a fő termékké váló információ, a lassan egymásbaolvadó információ média, valamint a kultúrává váló információ. Az információ saját jogán egyre inkább áruvá vált.” (Kellerman 2002b, p. 14.) - fordítás tőlem. ${ }^{121}$
} 


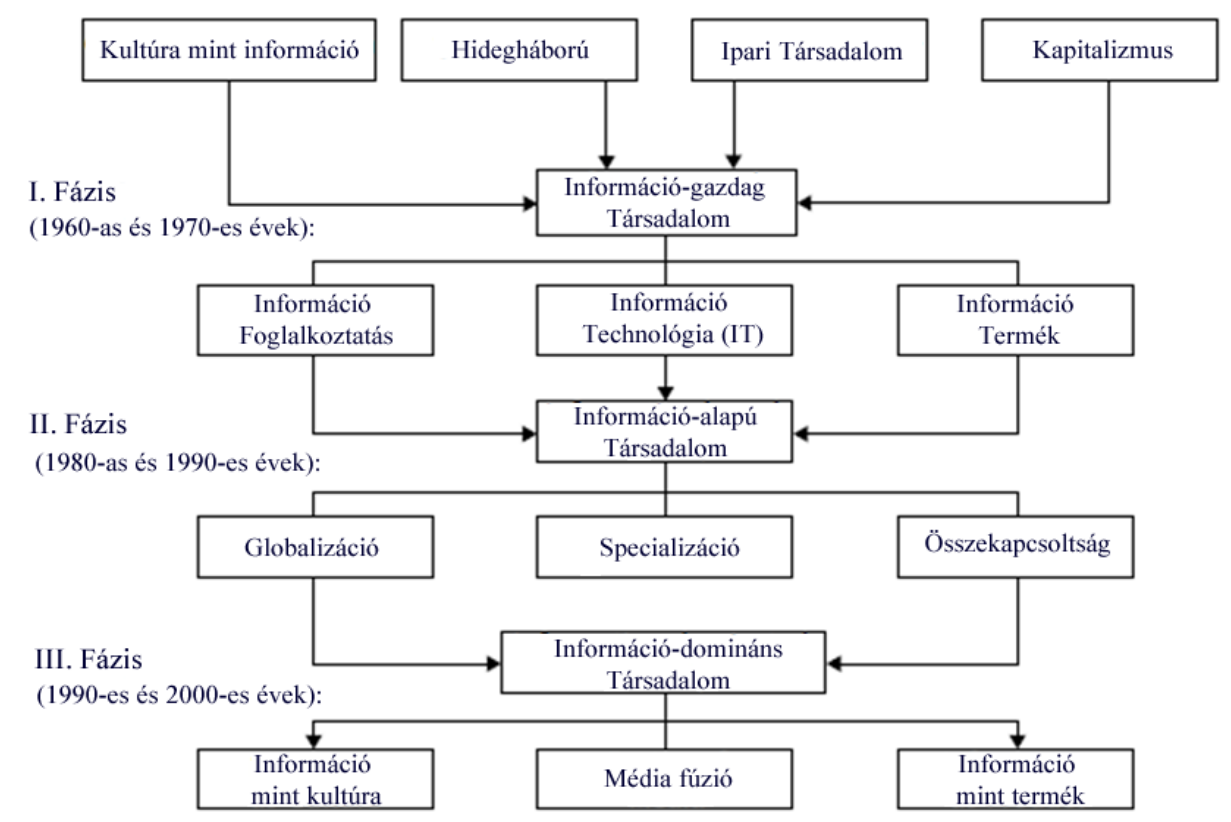

6. ábra. Az információs társadalom felbukkanásának fázisai (Kellerman 2002b, p. 11.)

Az árucikké vált információból származó árbevételek a 90-es évek végén egyre inkább az anyagi termékek és szolgáltatások kereskedelméből származtak, s ekkorra fokozatosan az USA vált a világ egyik vezető, elektronikus információt (termékeket) elosztó és eladó központjává. Európában ez csak az ezredfordulót követően tapasztalható. A jelenség a szakirodalomban is visszatükröződik azzal, hogy az addig információs és kommunikációs technológiát egyre többen infokommunikációs technológiaként említik munkáikban.

„A háztartások információs szolgáltatásokkal történő ellátásában tapasztalt liberalizációs tendencia a technológiai fejlődésekkel együtt az információátadás és felhasználás különböző formáinak lehetséges összeolvadását vetítik előre. Ezáltal lehetségessé vált, például, hogy egy számítógépet telefonként, faxként és televízióként is használhassunk, illetve az is, hogy ezen szolgáltatások többségét egyetlen szolgáltatótól szerezzük be. Lehetséges, hogy ez az összeolvadás végül egyetlen információt létrehozó és felhasználó készüléket, továbbá egy úgynevezett közösségi adat- és szoftverhálózatokat eredményez (Halal 1993, Kellerman 1997).” (Kellerman 2002b, pp. 14-15.) - fordítás tőlem. ${ }^{122}$

Az információs társadalom fejlődését ebben a harmadik szakaszban az információ kultúrája határozza meg. Kellerman szerint sokan felismerték, hogy az információnak kulturális értéke van, az információ elősegíti, promócionálja a nemzetileg és egyénileg létrehozott kulturális értékeket, azon túlmenően, hogy esztétikai értéke van, nem csak átadható, eladható és fogyasztható, de Castells szerint az egyike a legnagyobb hatalomnak az információ korában: 
„A kulturális harcok az Információ Korának hatalmi harcai. Elsősorban a médiában és a média által vívják meg öket, a hatalom birtokosa viszont nem a média. A hatalom, a viselkedés előírásának képességeként, az információcsere és szimbólumkezelés hálózatainak kezében van, melyek társadalmi szereplőket, intézményeket és kulturális mozgalmakat kapcsolnak össze ikonok, szóvivők és intellektuális erősítők segítségével. A kultúra a hatalom forrásaként, és a hatalom a tőke forrásaként megalapozza az Információ Korának új társadalmi hierarchiáját.” (Castells 1998, p. 348, in. Kellerman 2002b, p. 15.). fordítás tőlem. $^{123}$

A kultúra ilyen mértékü hatalma globális tudati sztenderdeket hoz létre, és a lokális információkészletet összemossa a kollektívvel, aminek a veszélye, hogy csökkenti a kulturális diverzifikációt, az előnye pedig (a hálózatirányítási logika szerint) az egységes protokol szerinti müködés biztosítása. A kettő ugyan ellentmond egymásnak, vegyük észre, hogy a kisebb csoportok (már Wienernél tárgyalt) homeosztázisát is egyfajta sztenderdizáció, az adott csoport információkészletének homogenizációja hozza létre. Ahogy a szociális hálózatok keletkezésénél a gyenge kapcsolatok füzik fel az információáramlást (BarabásiAlbert 2003, p. 61.), biztosítják a kapcsolati protokollt az entitás és a csoportok között, úgy a globális infokommunikációs hálózatok „erős kapcsolatai között” megbúvó „gyenge kapcsolatok” is hasonló funkciókat látnak el. ${ }^{124}$ Az információ áramlása és készlete így térben és időben sem lesz kiegyenlített. A lokális homeosztázis biztosított marad, a globális hatások abszorbeálása azonban a nemzeti, kulturális és vallási identitások falába ütközik. A hálózati struktúra terjedésével globális egyidejüjég jelenik meg, ami jelentős sebességnövekedést és hatékonyságot jelenthet a munkában. A tér és idő egyidejüsége a nemzeti keretek elmosódását, a területiség hagyományos érzelmi és geometriai felfogásának torzulását eredményezi. A kulturális imperializmus a nemzetközi tőkeáramlás mellényzsebében érkezik és nem mint valami veszélyforrást érdemes vizsgálni, hanem mint az információs társadalom hálózati infrastruktúráját kiegészítő, a társadalmi-gazdasági tér természetes folyamatait támogató olyan információkészlet, amely szimbólumrendszerén keresztül a szükséges metodológiát is hordozza magával. Ez az információs társadalom terének kulturális dimenzió szerinti megközelítése.

Kellerman rövid történeti vázlatával azt szerettem volna demonstrálni, hogy a geográfiai diskurzusszintek sokkal összetettebbek, multi-dimenzionálisabbak, mint azt a klasszikus térelméletek értelmezési kerete biztosítani tudná. A fenti ábrán is jelzett négy különböző dimenzión túl még számos „búvópatakot” is megkülönböztethetünk, amely az információs társadalom térbeli folyamatait befolyásolják, s ezek között csupán az egyik Castells kulturális meghatározottsága.

Az információs társadalom térelmélete szorosan illeszkedik a jelenleg is ismert, elfogadott geográfiai elméletekhez, amely kapcsolódás (elméleti beágyazódás) egyben 
alapfeltétele és módszertani alapja is a dolgozat célkitüzésének. Az egyik elfogadott értelmezés csoport a fizikai térelméletek csoportja, amelyek jellemzően a fizikusok által meghatározott, leírt térgeometriákon alapulnak, gyökereit pedig megtaláljuk az eukleidészi newtoni térgeometriában. (Coulesis 1995, p. 218.) ${ }^{125}$ Erre alapozhatjuk a fizikailag lehatárolható helyek (physically bounded space) leírását is, ezek az objektív vagy abszolút terek. Ezekben a terekben zajló földrajzi folyamatokat leíró matematikai modellek mindmáig meghatározóak az elméleti interpretációk sorában, ahol a „térbeli formák nyelve” egyértelmüen a geometria. ${ }^{126}$

Az objektív vagy abszolút tér alapjain találjuk a társadalomföldrajzi kutatások társadalmi-gazdasági terét is. A földrajzi környezet sokáig - a Föld egyes térségeiben még mindig - determinisztikusan határozta meg a gazdaság térbeli elrendeződését, míg napjainkban a térbeli gazdasági hálózatok, a globális vállalatok tevékenysége köthető ahhoz az interdependenciához, amely a térbeli és gazdasági tényezők között kimutatható. ${ }^{127}$ (Mészáros 2003, p. 33.) Ha változás is történt, mármint a gazdasági és társadalmi terek elrendeződésében, az ember gazdasági tevékenységének és kapcsolatainak relatív elhelyezkedése, akár társadalmi, akár ökonómiai oldalról nézzük, alapvető kérdés maradt.

$\mathrm{Az}$ abszolút értelemben vett tér objektivitása mellett ott találjuk azokat az eltérö térértelmezéseket is, amelyeket a behavioristák révén ismerhetünk: a mentális terek elméletét. A mentális terek, és ahhoz kapcsolódó mentális térképezést folytató behaviorista mozgalom már a társadalomföldrajzi fogalomrendszerhez képest eltérő tér-tipológiával manipulál. A behaviorista elméletalkotók abszolút (földrajzi) és szubjektív (viselkedési) tereket tipizálnak. Bár ezek kritikája, a szubjektivitásuk miatt, gyakran a „,puha értelmezés” jelzővel illeti a vizsgálati eredményeket, az elmúlt évtizedek munkái igazolták, hogy a „kemény értelmezési” kerettel bíró kvantitatív irányzatokkal szemben is tud érdemi eredményeket felmutatni. A geográfia új térfelfogását hozó behavioristák bebizonyították, hogy a tér „társadalmi elfogadottsága” legalább annyira pontosan és megbízhatóan feltárja a differenciált térhasználattal kapcsolatos összefüggéseket, a térformálás szociális aspektusait, mint a kvantitatív módszerek, sőt egyes esetekben attól pontosabb, finomabb összefüggéseket is képes a felszínre hozni. A lokalitáshoz, a hely és tér érzékeléshez (location, locality and sens of space) kapcsolódó behavioristák a térértelmezések egy újabb rétegét adták.

Az eddig vázolt elméletek mindannyian a természet- vagy társadalomtudományi iskolák valamelyikéhez tartoznak. Az elméleti eredményeik kifinomult matematikai és statisztikai alkalmazásokon nyugszanak, annak a racionális megfontolásnak az érdekében, hogy a természeti és társadalmi világot tudományos igényességgel megérthessük. De éppen a behaviorista térfelfogás az, amely végül is fontolóra vette: a szubjektív teret objektív 
mérésekkel vizsgálja meg, és ez által beilleszthetővé válik Sack (1980) szofisztikált tér fragmentációjának kategóriáiba. (Coulesis 1995, pp. 228-229.)

Bármely geográfus iskola tér értelmezést is nézzük, az ember, mint önálló entitás ott áll önmagában, abban a földrajzi környezetben, amelyet saját érzékszervein keresztül fog fel, és amelyet saját információkészletében raktároz el, entitását sajátos szürőkön, kommunikációs csatornákon keresztül ruházza fel környezeti attribútumokkal. A hely ahol áll, az entitás tapasztalati tere (empirical space). A tapasztalati tér felöleli mind az intuitív, analizálatlan, elemzés nélküli, mind a térbeli értelmezés kifejezéstelen formáit, de még a tudatosult szakrális és misztikus tereket is ide sorolhatjuk. Sack későbbi térkoncepcióiban szofisztikálatlan fúziónak (unsophisticated-fused) nevezte a tapasztalati tereket, mert úgy tünik, ebben a kontextusban nem releváns és összeomlik az objektív és szubjektív, tér és anyag koncepciója. ${ }^{128}$ Coulesis szerint ezek azonban csak a tudományos és analitikus nézőpontból tünnek szofisztikálatlannak. ${ }^{129}$ Ezek ugyanis a legkevésbé nevezhetők egyszerü térbeli folyamatoknak, ha például egyetlen intuitív tér-felismerési (szenzomotoros) folyamat tökéletesítése is lényegében állandó, mindennapi alapvető követelmény egy olyan hétköznapi feladat megoldása esetében is, mint például egy csésze megragadása, a szánkhoz emelése és a kávé elfogyasztása anélkül, hogy kiöntenénk. Napjainkban még ez az egyszerünek tűnő feladat is komoly nehézségekbe ütközik a legszofisztikáltabb robotnak is. ${ }^{130}$ (p. 229.)

Mészáros szerint a tapasztalati vagy empirikus térnek „ezt az abszolutista vagy esszencialista felfogását már egyre kevesebben fogadják el”, mert ahelyett, hogy a tér fizikai kutatásainak eredményeit használná, a „teret relációsnak nevezi.” (Mészáros 2003, p. 36.) Massey értelmezése kiválóan példázza ezt a relációs elképzelést, mivel a matematikailag leírt teret annak megfelelően tagolja, ahogy az emberi felhasználás szempontjából értelmet nyer. (Massey 1994, in. Mészáros 2003, p. 36.) A tér társadalmi konstrukciós elmélete természetesen nem újdonság a geográfiai elméletek között, és az emberföldrajz - társadalom tér vizsgálati háromszögben mindenképp ezek a társadalmi tér konstrukciók összefüggéseinek vizsgálatai érdemelnek prioritást. ${ }^{131}$ Ennek fontosságát azért emelném ki, mert hipotézisem szerint az információs társadalom térbeliségének létezik egy ilyen, ebből az aspektusból is értelmezhető vetülete. Mielőtt rátérnénk az információs társadalom terének részletesebb ismertetésére, foglaljuk össze Coulesis segítségével az egyes térfelfogásokat és terminológiájukat. 


\begin{tabular}{|c|c|c|c|}
\hline Matematikai & Szocio-ökonómiai & Magatartási & Tapasztalati \\
\hline Pont & Elhelyezkedés & Tájékozódási pont & Hely \\
\hline Vonal & Útpálya & Útvonal & Út \\
\hline Terület & Régió & Környék & Terület \\
\hline Sík & Síkság & Környezet & Birtokolt (föld)terület \\
\hline Konfiguráció & Megoszlás & Térbeli elrendezés & Világ \\
\hline
\end{tabular}

3. táblázat. A négy tér és terminológiájuk Coulesis szerint (Coulesis 1995, p. 231.) - fordítás tőlem.

A táblázat összefoglalja a négy elméleti diskurzus legfontosabb terminológiai jegyeit. Mindezt Coulesis egy egymásba ágyazott „fészek modell” segítségével is igyekezett összefüggéseiben bemutatni (Coulesis 1995, p. 232.):

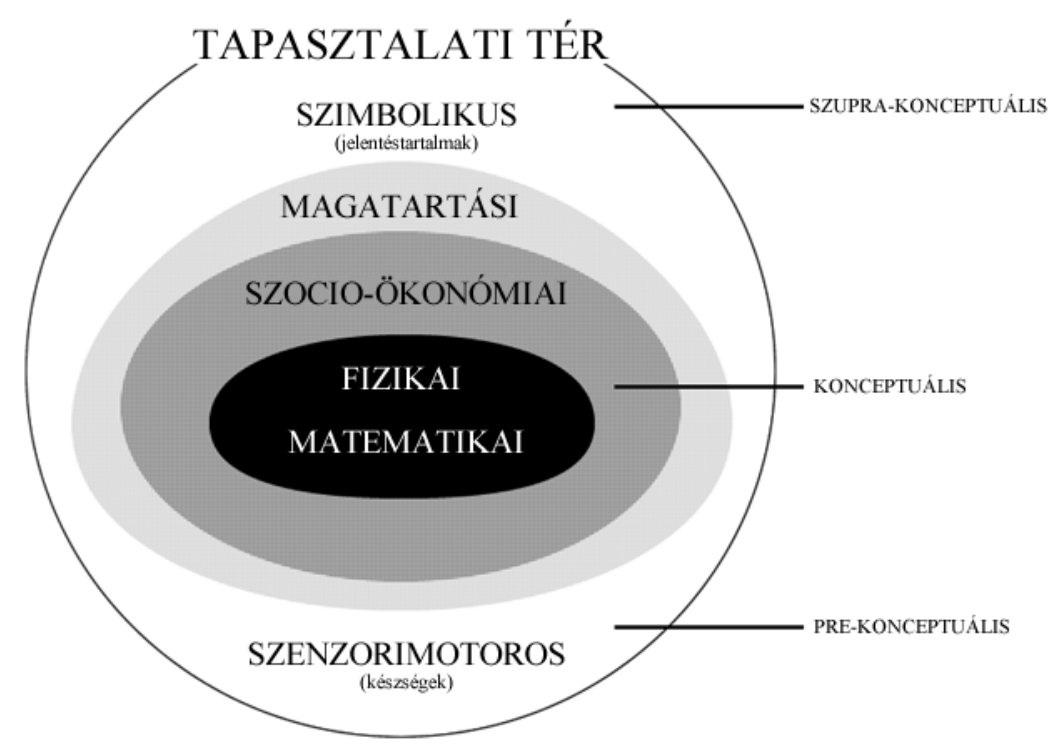

7. ábra. Fészek model - a matematikai, fizikai, szocio-ökonómiai, magatartási és tapasztalati tér egymásba ágyazott hierarchiája Coulesis szerint. (Coulesis 1995, p. 232.) - Az eredeti ábra alapján általam készített reprodukció.

\section{Egy dualista térkonstrukció születése}

A szakirodalom ugyan nem teljesen egységes a valós és virtuális terek együttes fogalmának tekintetében, a legelterjedtebb meghatározás a hibrid tér (hybrid space) kifejezés, 
amit én többnyire dualista térnek fogok nevezni. ${ }^{132}$ A döntés oka az, hogy a 'dualista' jelző véleményem szerint jobban kifejezi a két tér kettősségét, míg a hibrid tér egy állandósult, kevert térformára utal. Ezt támasztja alá számos társadalomföldrajzi, szociológiai kutatás is, amely a „digitális szakadék” fogalmával éppen ezt a kettősséget hangsúlyozza.

Visszatérve a Coulesis által megkezdett terminológiához, Kellerman (2006) a tér különféle interpretációinak rétegeivel operál, amelyek közül fentebb már a legalsó két réteget igyekeztem megfeleltetni Coulesis elméleti diskurzus szintjeinek. A további szintek megfeleltetése már problémát okozna, hiszen Kellerman már Coulesis-el szemben nem követi Sack tér koncepciójának a logikáját, helyette Harvey értelmezésével ért egyet, aki szerint a tér szemantikailag „az egyike a leginkább sokszorosan rétegzett és sokszoros szándékkal/funkcionalitással jellemezhető szavaknak a nyelvünkben."133 A narratív nézőpontot követve ennél is továbblép és Castells térdefinícióját is beveti annak érdekében, hogy az információs társadalom több rétegzettségű identitását és tér interpretációit együttesen tudja értelmezni:

„a tér anyagi produktum, és összefügg más anyagi tényezőkkel, köztük az emberekkel, akik [történelmileg] meghatározott társadalmi kapcsolatokban állnak egymással, amelyek révén a teret formával, funkcióval és társadalmi jelentéssel ruházzák fel.” (Castells 2005, p. 532.) ${ }^{134}$

Castells egyébként itt nem áll meg a gondolatmenetben, és szintén Harvey egyik munkájára hivatkozva a következőt idézi tőle: ${ }^{135}$

„Materialista szemlélettel azt mondhatjuk, hogy az idő és a tér objektív fogalmai szükségképpen anyagi jelenségek, és olyan folyamatok révén jönnek létre, amelyek a társadalmi élet reprodukcióját szolgálják. [...] Vizsgálódásaim alapvető axiómája, hogy a tér és az idő nem érthető meg a társadalmi cselekvéstől függetlenül.” (Harvey 1990, in. Castells 2005, p. 532.)

Az idézet a társadalmi konstrukció elméletek társadalomföldrajzi beágyazottságát mutatja. A fizikai tér magyarázatok esetében egyértelműen a matematikailag leírható, az anyag dinamikájára koncentráló elmélettel kellene kísérleteznünk, társadalomföldrajzi aspektusból azonban a társadalom dinamikájára, gyakorlatára kell elmélkedésünket alapozni. Castells, Harvey és Kellerman tulajdonképpen egyetért abban, hogy a tér az aktuálisan létrejövő társadalmi formák produktuma. ${ }^{136}$ Castells pedig konkrétan meg is fogalmazza, hogy „a létrejövő társadalmi formák és az információs technológiai paradigma kombinált hatása alatt mind a tér, mind az idő átalakul." (Castells 2005, p. 494.) Mindemellett felhívja a figyelmet arra, hogy ez a formai átalakulás nem „a technológiai determinizmus racionális” kivetítődése következtében megy végbe, inkább egy innovatív miliö (milieu of innovation) előfeltétele. (Castells 2005, p. 507.) Az információtechnológiai paradigma miliője ennek 
megfelelően nem egy térbeli dimenzió lesz ${ }^{137}$, inkább azt az interakcióra alapuló gazdasági környezetet jelzi, ahogy a csúcstechnológia szereplöi, a puszta térbeli halmozódás (lásd telephely elméletek) helyett, elindulnak a mutual compatibility üzleti modelljén alapuló (hálózat alapú) együttmúködés irányába. Nem a telephelyek, gazdasági szervezetek egymásra halmozódása, valamiféle térbeli koncentrációja, hanem a köztük kialakult interakciók, gazdasági kapcsolatok és a poszt-modern trendeknek megfelelő, az aktuális technológiai fejlettségi szintnek megfelelő „információkészlet-gazdálkodáson” alapuló társadalmigazdasági holisztikus egység létrehozása eredményezi (nem dimenzionálisan) a tér, paradigma szerinti egyedi miliőjét.

A terek egyediségének kialakításában három elem komplementer hatása játszik szerepet: az elhelyezkedés, a hely és tér érzékelés. ${ }^{138}$ Kellermannal egyetértve a hely, amely minden esetben rendelkezik egy földrajzilag azonosítható címmel (lényegében egy geo kóddal) ${ }^{139}$, egyszerre hordozza magában a fizikai jellemzőit, és ezen felül számos kulturálistörténeti identitást is, s ez a két dimenzió együtt hozza létre a lakosok térbeli kötődésének evolúcióját (lokális identitás). Egy olyan világban, amelyben a kommunikáció (és a kommunikációs formák) szerepe egyre növekszik, a hely nem tekinthető csupán fizikai entitásokat halmazának ${ }^{140}$, mert annak hézagait megtöltik a kulturális/humán identitások, ráadásul azok, az eddigiekkel összhangban, egymással szoros kölcsönhatásban vannak. (Kellerman 2006, p. 129.) Ez a gondolatmenet már kapcsolatot teremt a hálózati entitás és a hálózati identitás fogalmaihoz is, melyek értelmezéskörében az információs társadalom tér elemeit, térformáit tovább tipizálhatjuk „a kommunikációt támogató fizikai és társadalmi struktúrák által”.

Paul Adams (1998, p. 94.) szerint a tér olyan mintha a „kommunikáció és cselekvés összefonódása” lenne, és hozzáteszi, hogy a múltban a terek a kommunikációs hálózatok előnyeit elsősorban fizikai entitásokon (térbeli korlátokon és testeken) keresztül élvezhették, míg napjainkban egy komputerizált kommunikációs hálózat által közvetített jelek és kódok áramlásából épül fel, és ez lényegesen bonyolultabb tér struktúrákat és identitásokat eredményez. ${ }^{141}$ Adams megállapítása kulcsfontosságú a dolgozat tárgyalása szempontjából, mert utal a megváltozott miliőre (az entitások kapcsolatának hálózati szerveződésére) és finoman utal a funkcionalitás módosulására is, amikor a „kommunikáció és cselekvés” együttes fogalmát kiemeli. Ez utóbbi az ergon és a logos újbóli együttes megjelenésére utal, ráadásul (ahogy azt az empirikus tapasztalatok igazolták) ${ }^{142}$ nem tisztán, ugyanis az ergon és a logos magához emeli a poesis és paidea funkcióit, publikációs metodikáit is. ${ }^{143}$

Mindemellett a kibertér növekvő térnyerése a társadalmi érintkezésekben és a kapcsolatépítések (hálózatosodás) területén arra utal, hogy a kommunikációra használt (abszolút térbeli) helyek jelentősége csökken, míg ezzel paralel a kommunikáló emberek 
száma növekszik. Térbeli átrendeződés történik, a fizikai térből a virtuális térbe, így a valós és virtuális terek szimbiotikus mutualizmusából létrejövő kommunikációs élettér lesz a társadalmi paradigma miliője. ${ }^{144}$ Számos kutató mindemellett hangsúlyozza, hogy a helyi társadalmi kapcsolatok, események továbbra is meghatározóak, még akkor is, ha a helyi dolgokról globális szinten születik döntés. A helyi események lokális és globális kapcsolatokkal (linkekkel) egyszerre rendelkeznek, s ebben a kibertér valós és virtuális kapcsolódási pontjai, eszközei játsszák a föszerepet. ${ }^{145}$ A Kellerman által említett források ugyan nem mondják ki, de valójában ezek lesznek azok az átjárók, amelyeket Æsahcettr kimetsz számunkra az információs társadalom fizikai (abszolút) tere és a kibertér (relatív) virtuális tere között, átjárást biztosítva a világok, a valóságos és virtuális valóság miliők között.

Kellerman szerint a tér interpretációk rétegeinek csúcsán a növekvő kibertér használat, mint a különböző aktivitások termékének a helyszíne található, karakterét tekintve pedig egy tér, hely és technológiai hálózatok fúziójából álló produktum. A hely interpretációk alján a fizikailag lehatárolható lokalitás, az értelmezési réteg csúcsán pedig az említett tér-fúziós réteg. Kellerman által megfogalmazott, és részben bemutatott hely interpretációs rétegeket az alábbi ábra szemlélteti:

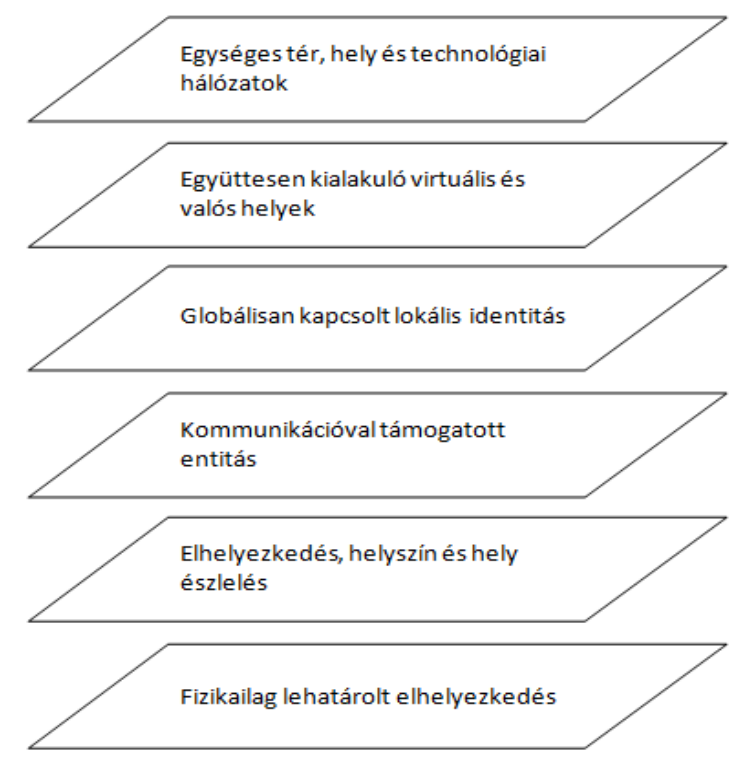

8. ábra. A hely interpretációk rétegei (Kellerman 2002b, p. 39, 2006, p. 130.) - forditás tỏlem.

Az egyes értelmezési rétegek ugyan hierarchikus elrendezkedést mutatnak, közöttük nem találunk direkt kauzálitást. A rétegek egyenként is biztosítják a hely fogalmának értelmezési keretét, azt azonban észre kell vennünk, hogy mi határozza meg az alá és felé rendeltséget. A hierarchikus rétegződésért a kommunikációs technológia és az általa közvetített információ mennyisége a felelős. Ez esetben a kommunikációs technológia alatt az 
emberi hangátvitelt éppúgy értjük, mint napjaink legkorszerübb optikai adatátviteli hálózatát. A két szélső példa egy földrajzi skálán a néhány métertől a kontinenseket átszelő hálózatig terjedhet. ${ }^{146}$ Az egyes interpretációkon belül is igen széles léptékkel dolgozhatunk, amelyet az értelmezési keret kommunikációs fejlettségi szintje, és az adott helyen végzett tevékenység dinamikája határozhat meg. A valós fizikai távolság és a szomszédság elve a rétegek halmozódásával egyre inkább veszít jelentőségéből, metaforikussá válik. ${ }^{147}$

A térben zajló tevékenységre, a tevékenységhez kötődő minimális térigény és a kommunikáció kapcsolatára más kutatók munkájában is találunk utalást. E. T. Hall proxemikai percepcióra ${ }^{148}$ vonatkozó kutatásai nem csak kultúrantropológiai szempontból érdekesek, hanem geográfiai szempontból is. Hall ugyanis igen izgalmas észrevételt tesz könyvében, a drasztikus és értelmetlen urbanizáció ellen szólal fel, vizionálva annak önpusztító jövőképét. ${ }^{149}$ A túlnépesedés miatt bekövetkező „szink” (behavioural sink ${ }^{150}$ ), az ún. „kiborulás”, az a pillanat, amikor az adott biotóp már nem képes több egyedet eltartani, illetve fennáll annak a veszélye, hogy az adott élettér önmagát is elpusztítja, ha nem lesz képes szabályozni a népsürüséget. Bár az idézett írás a túlzott városiasodás veszélyeiről szól, vegyünk észre néhány köztes üzenetet is. Az egyik ilyen, hogy Hall adott számú entitáshoz, adott méretü és minöségü teret rendelne. Nem szabad tehát a tér tipológiai elemzésénél figyelmen kívül hagyni annak méretét, minőségét és tartalmát. ${ }^{151}$ A másik észrevétel a biotópokra vonatkozik, amikor Hall kiemeli, hogy egy más típusú, összetételü (lényegében eltérő információkészlettel, és eltérő kulturális identitással rendelkező) csoport integrálása a megváltozott miliőböl fakadóan jelentös attitüdváltást is kikényszerit azoktól, akik az életterüket megváltoztatják. ${ }^{152}$ Az attitüdváltás kényszere, életmód béli asszimilációt követel meg az egyéntől, a csoport új tagjától. Ezt abban az esetben teheti meg, ha asszimilálja mindazt az információkészletből, amit az új közegben (a biotópban) a csoport birtokol, vagyis információt fogad el és részben/egészben információt közöl a közösség felé. Hall úgy foglalja össze a problémát, hogy kiemeli a szokatlan kommunikációs formák miatti veszélyeket, amelyekhez társul a megfelelő terek hiánya, melyeket az asszimilációra kényszerülő egyén/közösség addig birtokolt, s ezek együttesen tragikus következményekkel járhatnak az egyénekre/közösségekre nézve. ${ }^{153}$

Az idézet, a térelméletek egy másik, antropológiai szemléletű megközelítésére kívánta felhívni a figyelmet, jelezve azt, hogy a továbbiakban a hagyományos geográfiai értelmezések mellett további „bünbeesések” várhatók a téma kifejtése érdekében, és természetesen a geográfia interdiszplinaritása jegyében. ${ }^{154}$ 


\section{A kváziplasztikus földrajzi térkategória tipológiai olvasatai}

A geográfusok számára nem ismeretlen a kváziplasztikus kifejezés. Jellemzően geológiai aspektusban fordul elő, és az asztenoszféra anyagának jellemzésére használatos, amely lassú erőhatásra folyadékként viselkedik (elnyelve például az alábukó kőzetlemezeket), míg hirtelen erőhatásra szilárd anyagként viselkedik. A kváziplasztikus jelző éppen ezt a kettősséget kívánja szimbolizálni, amikor az információs társadalom terének tipologizálására kísérletet teszünk. Az információs társadalom tere, véleményem szerint, mint a társadalmi konstrukció terméke egy fizikai és egy virtuális vetülettel bíró konstrukció. Belső dinamikáját tekintve: a fizikai vetületet képező (hálózati pont/lineáris) infrastruktúra ${ }^{155}$ és a virtuálist képező kibertér mindenkori együttes hatásáról beszélhetünk, amely során lokálisan csak egyetlen pontban találkozik a két térdimenzió, az észlelés pontjában. Ebben a pontban a megfelelő specifikumokkal rendelkező interfész ${ }^{156}$ átjárót képez az objektív és szubjektív létezés között. ${ }^{157}$ Fontos kiemelni, hogy együttes hatásról, együttes jelenlétről van szó, mely esetben ezek a terek semmilyen formában nem értelmezhetők önmagukban. Természetesen vizsgálhatók egyes alakzatai mind kvantitatív, mind kvalitatív módszerekkel önállóan is, de értelmezési kerete minden esetben csakis együttesen képzelhető el. Az a földrajzi entitás ${ }^{158}$, amely valamilyen földrajzi attribútumot hordoz, vesz át például közvetítés céljából, illetve befogad, az részt vesz az észlelés és információ átadás folyamatában. Ennek a relációnak csak abban az esetben van értelme az információs társadalom esetében, ha a két „világ” között létező és dialektikus interakció van, ellenkező esetben az adott entitás úm. csak statisztikailag létezik. ${ }^{159} \mathrm{Az}$ információs társadalom terét tehát elsősorban a folyamatok határozzák meg, hozzák létre, és az emberi tevékenységhez szükséges fizikai és virtuális biotópok is folyamatok (process) által generálódnak. Adams megfogalmazásában:

„Amennyiben, a strukturalisták nézetei szerint, a hely folyamat (Pred 1984b), akkor a folyamat is lehet hely; ezen folyamat-beli hasonlóságból adódik, hogy a hely egy olyan folyamatot jelöl, amely az anyagi struktúrától és elhelyezkedéstől szétválasztható.” (Adams 1998, p. 94.) - fordítás tőlem. ${ }^{160}$

$\mathrm{Az}$ abszolút (fizikai) térben kötött szabályrendszerben épülhetnek fel az információs hálózatok, de míg a fizikai felépítmény mintázata változatosságot mutat, a logikai felépítés egy adott hálózati fácies esetében ritkán tér el jelentősen egymástól. Ennek magyarázata a következő: míg a fizikai hálózatot (mint vonalas infrastruktúrát) gyakran a természeti földrajzi determinizmus határozza meg, addig a logikai architektúra adott időszakra, technológiai fejlettségre adoptálható mintákat követ. Lényegében arról van szó, hogy az egyes hálózati eszközök egy adott technológiai fejlettségi szinten (a mutual compatibility elve szerint) közel azonos logikai interfésszel rendelkeznek annak érdekében, hogy kapcsolódni tudjanak 
egymáshoz, ami egyben a hálózati arculat (fácies) időbélyege. Ha ismert az eszköz, tudjuk mikor és hol használhatták. Épp olyan lenyomata van, mint egy fosszíliának, csak éppen ez egy technológiatörténeti fosszília. ${ }^{161}$ A hálózat fizikai mintázatának említett változatossága pedig jellemzően abból a természeti földrajzi determinizmusból adódik, miszerint az egyes hálózatok telepítése minden esetben az épített és természeti környezet figyelembevételével történik. ${ }^{162}$ A társadalmi elvárások viszont itt ritkán kapnak szerepet. ${ }^{163}$

Az információs társadalom tere (ISS - Information Society Space) rendkívül összetett, vizsgálati módszereit tekintve sokáig kiforratlan, lényegében csak probléma, illetve szakmacentrikus megközelítést tett lehetővé. Az információs társadalom földrajzi terének (GISS Geography of Information Society Space) kutatása ennek megfelelően egy szintetizáló, erős interdiszciplinaritást követelő munka. Ez a tér nem egységes, de az egyes térelemek belső struktúráját tekintve sem nevezhetők homogénnek. Számos, önállóan is vizsgálat alá vonható egységekre bontható eleme ${ }^{164}$ mind egy-egy építőkockája a globális földrajzi információs társadalmi térnek, melyben képesek vagyunk társadalmi-gazdasági tevékenységet végezni, egyáltalán élni, létezni. (Sinka 2004, p. 195.)

Metaforákon, hasonlatokon és esetenként megszemélyesítéseken keresztül vagyunk képesek csak földrajzi fogalmainkat úgy alakítani, hogy az információs társadalom terének a kibertérre eső szegmensét is le tudjuk írni. A virtuális földrajz tipológiájának rövid összefoglalását adja Kibertér c. könyvében Mészáros Rezső (2003, pp. 23-25), aki ekkor még, értelemszerủen, nem olvashatta Aharon Kellerman cikkét, a Cyberspace Classification and Cognition: Information and Communications Cyberspaces-t. (Kellerman 2007, pp. 5-32.) Mindez azért érdekes, mert bár mindketten geográfusok, mindketten közel azonos referenciaforrásokat mozgatnak munkájukban mind primer, mind szekunder oldalon, Kellerman tipológiája már kevésbé vívódó, tisztább és határozottabb. Mindez nem rangsor, hanem idő kérdése. Elegendő volt csupán négy év, és a geográfusok számára is sokkal letisztultabb és kiforrottabb megközelítési módok születtek. ${ }^{165}$ Az insider mellet ismét feltünik az outsider nézőpontja, a formálódó paradigma közkinccsé válik, elfogadják. ${ }^{166} \mathrm{~A}$ továbblépés érdekében azonban az egyes diszciplínák térértelmezéseinek a megismerése, fogalmi rendszereik befogadása, szükség szerint asszimilációja a geográfiai szak- és közgondolkodásba elengedhetetlenné válik.

E. T. Hall antropológus könyvében számos tértípust elkülönít és tárgyal proxemikai kutatása kapcsán. A vizuális és auditív tér mellett olyan izgalmas megközelítések is megjelennek, mint a szaglási, termikus és tapintási tér. Ha ehhez, a fentebb már említett, McLuhan féle tipográfiai teret is ide vesszük akkor nem a káosz, hanem a tisztánlátás lehetőségét növeljük, mivel minderre szükségünk van, ha a földrajzi környezet észlelésére, az észlelés hatására a gondolkodásunkat befolyásoló folyamatok vizsgálatára vállalkozunk. Nem 
kell feldolgoznunk minden említett tértípust, de figyelembe kell venni vizsgálati aspektusként annak lehetőségét, hogy a hagyományos tipológia helyett lehet, hogy egy új megközelítés hozza meg a sikert és a hagyományosnak mondható térelméletek mellé absztrakt tipológiát is létre kell hozni. Természetesen illik a kettőt összevetni, mint ahogy Kellerman segítségével ezt később meg is próbálom. Ahogy Batty felfogására hivatkozva Mészáros fogalmaz: „a földrajztudomány hagyományosan elválasztja az absztrakt geográfiai teret a konkrét helyek eredeti területétől" ugyan, e felfogás ellenére Mészárossal egyetértve kijelenthetjük, hogy ontológiai státusát tekintve a tudományos értelemben vett tér/hely dichotómia nem különbözik a kibertér/hely dichotómiától, inkább kiegészíti azt. (Mészáros 2003, p. 24-25.) Később Kellerman tipológiai megközelítése is ezt az egymásba ágyazottságot és függőséget fogja hangsúlyozni. A virtuális földrajz tipológiája, mint minden új terület, ma még talán túl összetett és bonyolult, és jobban hasonlít a földrajzi felfedezések korára, mint kitaposott ösvényre. Ahogy a dán Troels Degn Johansson fogalmaz egyik kutatása bevezetőjében: ${ }^{167}$

\footnotetext{
„Az elgondolás alapján, miszerint egy ennyire összetett adathalmazt egy adott, a földrajzi világ jellemzésére irányuló hipotézis és nem pedig a hagyományos felfogás szerint kell kezelni, rendezni és elemezni, Goodchild meghatározza “a földrajzi kutatás második korszakát”; egy olyan kutatást, amely nyilvánvalóan különbözik a „terra incognito” klasszikus kartográfiai feltárásától és feltérképezésétől.” (Troels Degn Johanson 2000, p. 5.) - fordítás tölem. ${ }^{168}$
}

Johansson a „földrajzi felfedezések másodkorának” nevezi Goodchild után a kibertér feltérképezését, s annak ellenére, hogy Batty felosztását követi, dolgozatában igyekszik vizsgálódásával azonosítani néhány újabb ontológiai és episztemológiai dimenziót a kibernetikus geográfiából és a modern kartográfia vizualizációjához kapcsolódóan. (Johansson 2000, pp. 21-22.) Igyekezete azért érdemel figyelmet, mert több „felhasználóközpontú" nézőpontot (aspektust) is elkülönít a kibergeográfiában, amellyel nem csak az insider nézőpont ezredforduló utáni továbbélését, de ismeretelméleti felvetései az outsider-ek új nemzedékének is utat enged, ráadásul a földrajzkutatás új területeként a kibernetikai paradigmát ontológiai alapvetésként kezeli, vélhetően persze Batty (1997) hatására. A kibertér technológiai fejlődéssel elmélyülő fogalmi rendszere Michael Batty már idézett Virtual geography c. munkájában bukkan fel talán a leginkább összefogottan:

„Az 1990-es években ezt a hálózati paradigmát nagybetűkkel írják, '...ez lesz a tudomány szimbóluma a következő évszázadban...' Kelly ${ }^{169}$ meggyőző érvelése szerint. Számítástechnika létrejöhet bármely két terület között, a szoftver és az adatok is hasonlóan távol lehetnek egymástól, illetve az adatfeldolgozás is történhet bárhol és bármikor. Ezen jelenség legjobb példája a világháló (World Wide Web) kialakulása, a késő 20. századi számítástechnikai nézetek összessége, amely sok szempontból az internet, az e-mail, a szoftverek és adatok letöltésének és felhasználásának; hirdetőtábláknak és hírcsoportoknak, valamint 
minden olyan egyéb információforrásnak vizuális érintkezési felülete, melyeket ma az internet zürzavaros szerkezete kapcsol össze. Az ebben a kibertérben kialakuló földrajz a legtisztább formájában valamely közös céllal összekapcsolt helyi közösségeket vagy érdekcsoportokat tükröz, virtuális közösségekként, virtuális önsegélyző csoportokként, az interneten keresztül egymással informálisan, hasznosan kommunikáló és tevékenykedő internetes tevékenységben megtestesült csoportokként; melyek éppoly mulandóak, mint az IRC ('internet relay chat', internetes csevegőprogram) a hivatalos kutatócsoportok számára, mint például a végpontok közti szakmai kommunikáción alapuló csoportok gyakran ismétlődő kérdésekkel, cikkek vázlataival, vagy a találkozók bejelentésével kapcsolatban akár a kibertérben, akár egy valós helyszínen. Népszerü dolog ezekről a földrajzokról beszélgetni, vizsgálódni, grafikonokat készíteni ${ }^{170}$ a földrajz azonban egyszerü, a terek pedig a mai napig csak felületesen és informálisan meghatározottak.” (Batty 1997, p. 344.) - fordítás tőlem. ${ }^{171}$

Batty észrevételei a kibertérrel kapcsolatban mára valóságos kordokumentumnak számítanak, mivel az információtechnológia fejlődésének és a kapcsolódó kutatásoknak köszönhetően mára egyes negatív megállapításait sikerült pozitív irányba állítani. A 90-es évek elején még magam is azt állítottam, hogy az információs társadalom a geográfusok negligált kutatási területe (Sinka 1994), de ezt az állításom, szerencsére, csak rövid ideig volt tartható. Az idézett rész azonban nem csak emiatt érdekes. A dolgozatom alap hipotézisének egyik kulcsfontosságú gondolatára található benne utalás, mert Batty szerint a 90-es években megjelenik a hálózati paradigma, melyet a késő 20. században a komputáció (computing) paradigmája vált fel. Batty természetesen még nem ismerhette sem Barabási-Albert László (2003), sem George Siemens (2006) és mások munkáit, hogy kijelenthesse, a 20. század végén előkészített, a posztindusztriális társadalmi formát meghaladó társadalmi alakulata egy olyan információs (információ-dominanciára épülő) társadalom, melynek társadalmigazdasági terét átszövő új paradigma a kibernetika lesz. ${ }^{172}$

A paradigmát formáló események természetes folytatása, hogy Kellerman (2007, pp. 532.) cikkében már alapvetően két, a kognitív információ kiberterét (cognitive information cyberspace, CIC) és a kognitív kommunikációs kiberteret (cognitive communications cyberspace, CCC) megkülönböztető osztályozást javasol, amely az ezzel egyenértékű kibertér klasszifikáción alapul, vagyis az információs kibertér és kommunikációs kibertér osztályain. Kellerman alapvető fontosságot tulajdonít a két kibertér típus megkülönböztetésének, míg Batty osztályozása egy évtizeddel előtte még meglehetősen elnagyoltnak tủnik, és csupán négy térkategóriával manipulál rendszerében. ${ }^{173}$ Kellerman osztályozása két okból is lényeges: az egyik, mert jóval szofisztikáltabb irányt kínál a geográfusok számára a kibertér vizsgálatához, ráadásul a kognitív jelzővel, a pszihológiai/filozófiai aspektus mellett, azt sugallja, hogy tapasztalati úton is szerezhetünk információkat a kibertérben, a megismerés lehetősége csupán formailag, módszertanilag tér el a hagyományostól. A másik fontos 
szempont, amit észre kell vennünk, az információ és a kommunikáció szerepének külön-külön történő kiemelése, amely egyértelműen a rendszerelvű megközelítésmód jellemzője, és az analízise már céltudatosan a megismerési algoritmusok, rekurzív interakciók sémáinak felderítésére irányul, de természetesen továbbra is a geográfus szemszögéből.

A két fó osztálytípusra tett javaslat már lehetőséget biztosít arra, hogy a monolitikus kibertér fogalmat finomabban tagolt részletekre bonthassuk. Az első lépés ennek érdekében, lehetőleg földrajzi perspektívából, hogy azonosítani kell azokat a folyamatokat, amelyek a térérzékelés során, a kognitív képességeken és folyamatokon keresztül elvezetnek a keletkező szubjektív produktumhoz és belső kognitív térképekhez. A szubjektív tartalom lényegében a földrajzi környezetről összegyüjtött információkészlet lesz, míg a kognitív térképünk annak belső, egyéni (agyi komputációs folyamatok által létrejött) reprezentációja. (1) A földrajzi információk elsődleges forrása a környezetünk közvetlen érzékelése és az érzékelhető információk abszorbeálása, vagyis a befogadással együtt történő rögzítése. A folyamat eredményeképpen képesek vagyunk rögzíteni és tanulni a környezetünkről felfogható információkat. (2) További ilyen befogadási folyamat az ún. másodlagos földrajzi információkat hordozó elemek, úgymint a térképek, a képek, a különféle szövegek vagy a kommunikáció útján megszerzett információk. (3) A harmadik forrás lényegében az előző kettő reprodukciója, újra feldolgozása és lényegében saját térbeli kognitív „előéletünkön” alapul, vagyis attól függ, milyen hatékonysággal voltunk képesek korábban feldolgozni az addig megismerhető földrajzi információkat. A múltbéli, újraszervezett és újrastrukturált térbeli információk specifikálják azt a tudást, amellyel környezetünkről rendelkezünk. Személyes és társadalmi térismeretünk és viselkedésünket meghatározó térbeli kogníciós folyamatok és kognitív térképek összefoglalása Kellerman (2007, p. 8.) szerint:

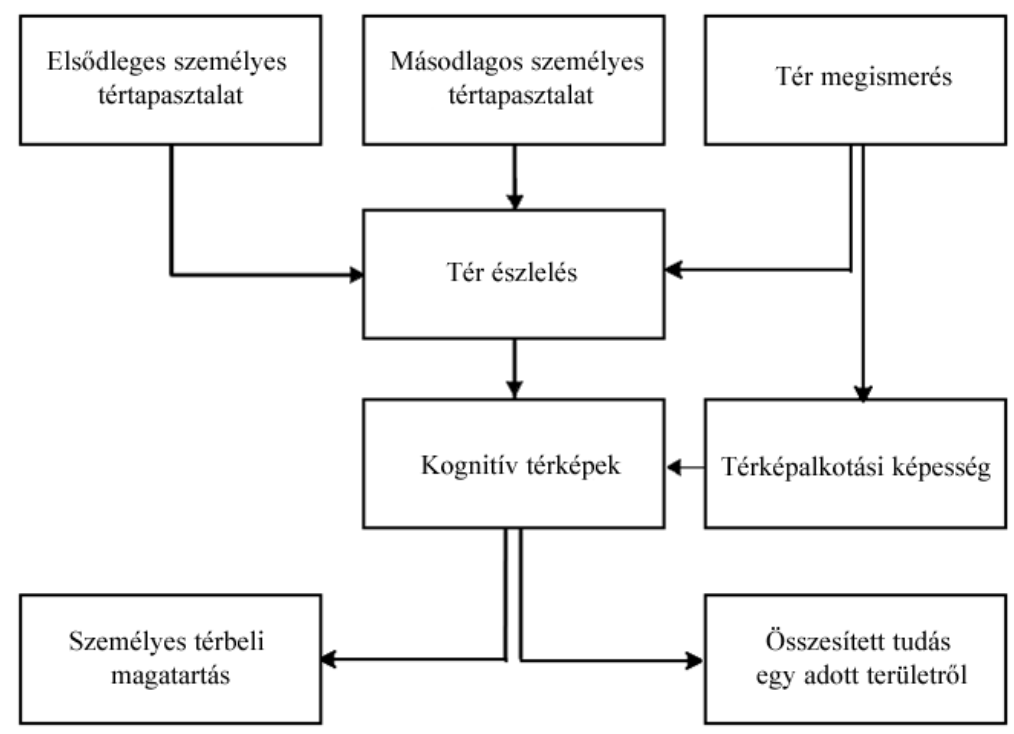

9. ábra. Térbeli kogníció és kognitív térképek (Kellerman 2007, p. 8.) -forditás tőlem. 
A 90-es évektől a figyelem középpontjába került kifejezés, a kibertér (cyberspace) mint köztudott William Gibson ${ }^{174}$ által alkotott fogalom, a sci-fi irodalom mára klasszikussá vált kifejezése. Kellerman erre vonatkozóan három definíciót mutat be a 90-es évektől az ezredfordulóig:

\begin{abstract}
„Mesterséges Valóság: “A kibertér egy globális hálózattal rendelkező, számítógéppel támogatott, számítógéppel elérhető és számítógéppel generált többdimenziós mesterséges, vagy “virtuális valóság." (Benedikt 1991, Kitchin 1998) ${ }^{175}$ - fordítás tőlem ${ }^{176}$

„Interaktivitási Tér: “A távoli felhasználók közti interaktivitás kiberteret határoz meg ... a kibertér nem feltétlenül képzelt tér - annyiban valós, hogy ezt a teret azok határozzák meg, akik távoli számítógépeket kommunikációra használnak.” (Batty 1997, pp. 334-344.) ${ }^{177}$ - fordítás tőlem ${ }^{178}$

„Konceptuális/Fogalmi Tér: “Az IKT-n (információs és kommunikációs technológiákon) belüli konceptuális tér, nem pedig a technológia maga.” (Dodge és Kitchnin 2001) - fordítás tőlem ${ }^{179}$
\end{abstract}

A kiemelt idézetek azt jelzik, hogy az információ technológia fejlődésével egyre szélesedett, egyre tágabb értelmet kapott a kibertér fogalma. A kezdeti térfelfogások jórészt még metaforákkal igyekeztek leírni a számítógépek és az információs rendszerek által létrehozott új virtuális entitásokat: megtestesült tér ${ }^{180}$, virtuális valóság és virtuális anyag ${ }^{181}$, helynélküli tér ${ }^{182}$ stb., miközben valós fizikai, materiális entitások természetszerüleg nem jöhettek létre. Mindazonáltal a kutatók többsége rövid időn belül egyetértett abban, hogy a kommunikációs hálózatokra épülő web nem csak a földrajzi, hanem a szociális kapcsolatok tere is. Sőt, valójában ez a társadalmi-gazdasági tér típus volt kezdettől fogva a leginkább zavarba ejtő virtuális alakzat, mégpedig azért, mert müködött. Müködött és müködik benne szinte valamennyi szociális interakció, és a társadalmi folyamatok szervezeti keretét is képes biztosítani. A legszembetűnőbb példa erre az e-közigazgatás, az e-learning, az e-business és újabban a web 2.0-ás technológiákra épülő tartalommegosztó alkalmazások virágzása vagy az egyre népszerübb online szerepjátékok. ${ }^{183}$

Kellerman a valós és virtuális terek jellegzetességeinek összehasonlítását, három dimenzió csoport mentén tárgyalja: a szerveződés (organization), a mozgás (movement) és a felhasználók (users) dimenziójában. Mindemellett megemlíti, hogy a virtuális térnek is van fizikai tere (térbeli leképeződése), ami történetesen a müveletekhez szükséges hardver, bár ez önmagában nem bír térbeli jelentőséggel. Az általam korábban hangsúlyozott kettősség nála is feltünik, miszerint a valós és virtuális tér csak együtt biztosítja az információs társadalom értelmezési keretét. Rövid összefoglalását is adja ennek a The Internet on earth: a geography of information c. könyvében, arról a szoros összefüggésről beszélve, amely a valós és a virtuális tér között jellemzően megfogalmazható. (Kellerman 2002b, p. 37.): (1) nagyon erős 
interdependencia a két tér funkcionalitásában; (2) a két tér együttes evolúciója; (3) a helyek és aktivitások együttes keletkezése és eltünése mindkét térben.

A kibertér nemcsak azt biztosítja, hogy az entitás szimultán több helyen is jelen legyen, de arra is módot ad, hogy egyszerre legyen jelen a valós és a virtuális térben, míg a valós tér csak egy lokációs pontot tesz lehetővé. Az erős interdependencia miatt azonban a funkcionalitás és az aktivitás szorosan összekapcsolódik. Mindkét térben zajlik aktivitás, és konstruálódnak terek, melyek együttesen jönnek létre vagy szünnek meg. Egy másik igen fontos észrevétel, hogy a kibertér manipulációján és a navigáción keresztül az internethasználat magában foglal egy metaforikus tér tapasztalatot, amely a földrajzi nyelv használatát, földrajzi jelentéstartalommal bíró szimbólumok és eszközök kiterjesztését, tükrözését jelenti. ${ }^{184}$ Kellerman a fizikai tér virtuális extenziójára utal a nyelvhasználat és a szimbólumrendszer kapcsán, míg Edward T. Hall (1966) ehhez nagyon hasonlóan fogalmaz (vö. Donald G. Janelle 1973) ${ }^{185}$, amikor az ember testi extenzióját fogalmazza meg könyvében. ${ }^{186}$ A testi extenzió egyedivé teszi az embert az állatvilágban, a virtualizált világ megteremtésével pedig olyan manipulációs dimenziókat hozott létre, amelyek az arra nem érdemesek számára rejtve maradnak. ${ }^{187} \mathrm{Az}$ érdemlegesség természetesen nem a jó és rossz fogalma körül, inkább egy materiális (IKT eszköz oldal) és immateriális (humán interfész) kompetencia portfólió köré rendeződik. Ahogy azt kicsit később látni fogjuk, a felhasználók dimenziójában jóval szabadabb és kötetlenebb, mégis nagyon is leszabályozott funkcionalitást határozhatunk meg, főként a szervezeti dimenzió szabályozott, a vezérelt elvekre és logikára épülő (kibernetikai) kapcsolatrendszert követelő felépítettsége miatt. ${ }^{188}$

A többrétegü hely interpretációk már bemutatott keretét később ki kell majd egészítenünk a többrétegü identitás fogalmával is. ${ }^{189}$ A jelentősége abban rejlik, hogy nem csak a lokalitásunk lehet multi-dimenzionális, multi-rétegzettségü, de az egyéni térbeli aktivitásunkhoz köthető identitásunk is. Bár fizikailag egy időpontban egy lokalitással rendelkezünk, a fizikai térben is váltogatjuk identitásunkat, még ha az térben és időben linearitást is mutat, függetlenül a szekvenciától. A virtuális térben azonban egy időben több lokalitást is be tudunk tölteni, s a többszörözött aktivitás (multiprocesszálás) többrétegű lokalitást és ezzel együtt többrétegü identitást is eredményez, amely már egyáltalán nem mutat sem időben, sem (virtuális) térben szekvenciális elrendezettséget. ${ }^{190}$ Tér és idő síkok itt egymásba csúszhatnak, fedésbe kerülhetnek, párhuzamos folyamatok futhatnak (paralel processzálás). Az emberek, mint pont-entitások ${ }^{191}$ virtuális időföldrajzi elemzése során a paralel folyamatok dimenzionálása a legnehezebb feladat. ${ }^{192}$ (Yu 2006, Yu és Shaw 2006, 2008.) Az infokommunikációs technológia által generált virtuális terek és kapcsolatok nem biztosítanak rögzíthető lokalitást, így a „fizikai aktivitás csak a fizikai közelség esetében valósul meg, míg a virtuális térben az IKT által engedélyezett lokációk mindegyikében 
végezhetünk aktivitást, éppen ezért két (úm. dualista) aktivitási térről beszélhetünk.” (Yu 2006, pp. 4-6) A dolgozat szempontjából mindez azért fontos, mert a paradigma miliője nem tiszta szekvenciális folyamatok által szervezett térkonstrukciókból fog állni, amelyet a tér-idő egymásutánisága határoz meg, hanem egy olyan vezérlés orientált logika építi fel, amely inkább eredeztethető a hálózatszervezödés logikájából, a párhuzamosan megosztott információ feldolgozó metódusokból (PDP - Parallel Distributed Processing), mint például az agymüködés vagy a legfejlettebb MI megoldásokra épülő komputációs technológiák.

\section{Az információs társadalom fizikai miliőjének határai}

A fejezetben szándékosan nem adtam mély és részletes tipológiai elemzést a területröl, ez nem ennek a dolgozatnak a felelőssége, inkább olvasatokat kínálok, amelyek a későbbiekben elvezethetnek a téma további kifejtéséhez. Ebben a traktusban a kibertér szociális térbe ágyazottságának, a két tér esszenciális kapcsolódási pontjainak felderítése volt a cél, melyet abban a duális térkonstrukcióban, amit információs társadalom terének nevezünk, zajló megismerési folyamatok klasszikus és új jelenségként aposztrofálható formáinak megismerésével egészít ki A kognitív geográfia c. következő fejezet.

A hangsúly itt a két tértípus mutualizmusának, interdependencián alapuló létezésüknek, paralel processzálással keletkező párhuzamos biotópjainak, és a metaforikus lokalitást biztosító hálózati komponensek felismerésén van. A kibernetika atyjának, Norbert Wienernek korábban idézett gondolata illik ide: „a közösség csak addig terjed, ameddig az információ átvitel terjed”. Az információs társadalom duális konstrukciós terére együttesen érvényes megfogalmazás egyértelmüen az entitások, csoportok, közösségek összekapcsolását, egy karakteres hálózati logikára épülő társadalmi konstrukciót és annak fizikai/virtuális rétegeit együttesen feltételezi. A térbeli alakzatokat, az aktivitási zónákat azok a folyamatok rajzolják ki, ahol az egyes entitások aktivitásukat kifejthetik, és ahol rendelkezésre áll a manipulációhoz szükséges tér, legyenek azok akár közvetlen fizikai szomszédsággal bíró helyek, akár IKT eszközökkel kiterjesztett virtuális lokációk, melyekben a szomszédság és a közelség metaforikus fogalmán keresztül a humán manipulációs tér és a benne zajló aktivitás értelmet nyer. A humán test és aktivitás infokommunikációs eszközökön keresztüli extenzionálása, ahogy azt Kellermannál láthattuk, az összegyűjthető földrajzi információk mennyiségét, minőségét és a feldolgozásuk folyamatát, szakaszait is befolyásolhatja.

Az ember által manipulálható tér szakaszosan, ha úgy tetszik a Kondratyev-ciklusok mentén ${ }^{193}$, minden esetre rohamtempóban bővül, és infoplanetáris méreteket ölt. A technológiai innovációk ${ }^{194}$ hatására (forradalomról forradalomra) kezdetben a Föld, majd a 
virtuális világ is globalizálódott, s lassan a naprendszer következik. ${ }^{195}$ A hely, a tér és az idő viszonyrendszere, súlypontja, irányultsága, észlelési és történésbeli folyamata drámai változásokon mennek keresztül. Az emberi térmanipuláció mára kinőtte bolygónkat és a naprendszer kereteit feszegeti. Úgy vélem a fentiek tükrében, hogy az információs társadalom földrajzi tere az ember valós és virtuális térmanipulációs képességének határáig terjed és kirajzolja az információs társadalom kváziplasztikus terét. ${ }^{196}$

A behaviorista forradalomnak és az emberközpontú földrajz elöretörésének köszönhetően az információs társadalom világképe, szemlélete egyfajta visszatérés a geocentrikus világkép modellhez, amely azonban nem jelent visszalépést is. Inkább megerősíti azt a gondolatmenetet, ami szerint a heliocentrikus világkép csak fizikai-csillagászati értelemben, az eukleidészi - newtoni háromdimenziós „kockában” jut jelentőséghez és egyre kevésbé jelent természeti determinizmust. Az ember élettere ma elméletileg korlátlan a bolygónkon. Híradásokból tudjuk, hogy rövidesen a Holdon és a Marson is megjelenhet az emberi életforma. Globalizált, kváziplasztikus térformák jönnek létre a Földön és a világürben attól függően, hol fordul elő az ember és/vagy az általa létrehozott információs technológia. A globális gazdaság átlép a nemzeti döntéshozók gazdaságpolitikai tervein, felborítja a hagyományos telephely elméleteket, és rendszerint nem érdekli a munkaerő képzettségi szintje sem. Vajon mit gondolna, erről Johann Heinrich von Thünen úr, a telephely elmélet atyja? Bár a gazdasági válságok és az azt kísérő energiaár emelések kordában tartják némileg azt a nemzeti-regionális kontextusban zajló gazdaságliberalizációs folyamatot, amely a tőke globális mozgását biztosítja, s megpróbálják a telephelyeket a képzett vagy a nagyszámú munkaerő körül tartani, elsősorban az emelkedő szállítási költségek és egyes ágazati érdekek miatt. A technológia fejlődése ezekben a központokban egyre több innovációval töltött miliőt, ún. technopole-t (Castells 2005, p. 507-508.) hoz létre, növelve az adott társadalom homeosztázisát biztosító kritikus tömeget gazdasági, kulturális és oktatási szempontból. A kritikus tömeget olyan információközösséget alkotó társadalmi csoportok jelentik, amelyek hordozzák a kollektív információkészletet, társadalmi folyamataik részeként megteremtik az aktivitási terüket, müködtetik a funkciókat és szervezeteket a csoportok közötti belső és köztes adatáramlást. A müködéshez pedig elengedhetetlen a kompetens humánerőforrás. ${ }^{197}$

\section{Emberi erőforrás fejlesztés - egy 'emberi diskurzus' szint}

Az emberi erőforrás fejlesztése a technopole-okhoz kapcsolódóan már elökerült, mint humánerőforrás. Az emberi erőforrás, humán erőforrásként, vagyis egyedi információkészlettel rendelkező szubjektív entitásként való értelmezése ${ }^{198}$ A konnektivizmus földrajza c. fejezet feladata lesz annak ellenére, hogy a két közel azonos írásmóddal 
rendelkező fogalom szorosan összekapcsolódik, sőt egyes szakirodalmakban nem is kerül szétválasztásra. Azonban nem csupán az Európai Unió ide vonatkozó szaknyelvi direktívái miatt tartom fontosnak ennek szétbontását, hanem a dolgozat célkitüzése miatt is. Egy meghatározott és lehatárolható keretbe tartozik a humánerőforrás, mint munkaerő, mint nyersanyag, mint tőke allokációs eszköz. Egy másik definíciós keretbe pedig a humán erőforrás, mint a humánerőforrás kompetencia portfólióját is megtestesítő szubjektív információkészlettel rendelkező entitás, és aki fontos szerepköröket tölt be a duális térkonstrukciókban: szervező, elem, csomópont, hordozó, közvetítő, és nem utolsó sorban interfész.

Az emberi erőforrás diskurzusa a vázolt kutatási irányokat kiegészítő problémakör, amely igen fontos szerepet tölt be véleményem szerint az információs társadalom adaptációs szintjének területi kiegyenlítődése/különbségei tekintetében. Területi leképeződései Magyarországon, és bárhol a világon, a humán erőforrásbázis térbeli differenciáltságára vezethető vissza. Bár kevés az ilyen jellegű kutatás, mivel a terület metodikája kidolgozatlan, illetve az egyes eltérő országstatisztikák miatt nehezen összevethető és számos úm. megfoghatatlan vagy nehezen definiálható/mérhető elemet is tartalmaz. Annak ellenére van ez így, hogy Z. Karvalics (2002), Kanalas (2003a, 2003b), Pintér (2004), Sinka (2005, 2006) és más kutatók munkáiban számos kísérletet találunk a tématerület feldolgozására. A konnektivizmus földrajza keretében a kompetencia alapú társadalom születését, a tudás társadalom, mint az információs kor paradigmájának érett miliőjét, és az azt meghatározó humán erőforrás entitások tér-idő funkcionalitását már a kognitív megismerés és a hálózati logika recens kontextusában érdemes megvizsgálni. A kortárs megközelítést azonban a geográfia, a pedagógia, a pszichológia és a hálózatok tudománya együtt fogja biztosítani, füszerezve az érintett pontokon az oktatási és tudáshálózatok történetiségével, és az új alexandriaiak színre lépésével. ${ }^{199}$

A geográfiai diskurzusszint természetesen itt nem ér véget. A fejezet célja az volt, hogy feltérképezze és tipológiai olvasatokat definiálva megpróbálja leírni azt a miliőt, amelyben az információs társadalom térbeli folyamatai zajlanak. A következő fejezetben, a kognitív geográfia keretében áttekintjük a térbeli megismerési folyamatokat és technikákat a kortárs (hálózati, MI, kibernetikai, kognitív tudományi) elméleti felfogások alapján, majd a klasszikus szimbólumfeldolgozó felfogás inherens bírálata mentén megpróbálunk eljutni az információs társadalom hibrid téralakzataiban zajló észlelés-paradigma megértéséhez. Mindez közelebb vihet az aktuális, információ technológiai meghatározottságot mutató földrajzi paradigma megértéséhez.

Részben összefoglalva: míg az információs társadalom társadalomtudományi és geográfiai diskurzusa a paradigma értelmezési terét, a környezeti miliőt, a kognitív geográfia 
az eszközkészletet, a hálózatok új tudományának vizsgálata pedig a szükséges protokollt biztosítja annak a fejlődési folyamatnak a részeként, amelyben a konnektivista pedagógia metodológiája mentén szerveződik a társadalmi koherenciát és homeosztázist biztosító információkészlet. A kognitív geográfia a következő lépés ezen az úton.

\section{A KOGNITÍV GEOGRÁFIA}

\section{A kognitív architektúrák, mint a megismerés építőkövei}

A kognitív geográfia nem új irányzat a geográfián belül. ${ }^{200}$ A behavioristák által a felszínre hozott szemléleti irány nem volt már akkor sem újdonság a földrajzban, csak egyszerüen a helyére került a már régóta tapasztalt jelenség, amely a valós és generalizált térábrázolások és a mentális konstrukciók között volt. A dolgok lényegében csupán a helyükre kerültek. Az ezredfordulót követően, s a geográfus irodalomban is szinte azonnal nyomot hagyó jelenség, a kibertér egyre realisztikusabb megjelenése és ezzel együtt a földrajzi kognitív folyamatokra gyakorolt nyilvánvaló hatása volt. A mentális térképekhez hasonlóan volt valami, ami részben a fizikai hálózathoz, részben az agyi folyamatokhoz, és részben valamihez köthető volt, de ez a valami csak lassan bukkant elö és mutatta meg magát. A valamire, a kognitív pszichológia és a hálózatok modern kutatásai derítettek fényt, $\mathrm{s}$ ha elsőre nem is közvetlen módon, de egyre magabiztosabban a szabályozással, a vezérléssel kapcsolatos kibernetika felé terelődött a figyelem. A kibertér egyszerre a társadalom és egyszerre az észlelő valamiféle extenziója. A társadalom szociális és gazdasági tér-extenziója a leggyakoribb, az entitások pedig e szociális-gazdasági tér-extenziók mentális felhasználói, az ott zajló aktivitásuk pedig különféle szociális és gazdasági céllal történik.

Ahogy Mei-Po Kwan ${ }^{201}$ fogalmaz, a két térhasználat között nem szabad lényeges különbséget tenni, mert ,a fizikai térben történő humán útkeresésből származó tudás alkalmazható konstrukció lehet a kibertérben is. Ami azt sugallja, hogy a magatartási modellek elméleti alapot nyújtanak a kibergeográfiához, különösen az egyéni kibertér hozzáférések esetében.”202 (Kwan 2001, p. 34.) Az általa rajzolt modell, mint látni fogjuk, egyébként kiegészíthető a másik oldalról is, amely a fizikai tér észlelésére vonatkozó kognitív - magatartási dimenziót ábrázolná. Erre irányul Kellerman szociális tér modelljének kísérlete is, aki szintén a kibertér kognitív folyamatainak egyedi vonásait, tipológiáját veszi számba. ${ }^{203}$ A cél természetesen az, hogy a környezeti objektumok (entitások) és a humán entitások közötti kognitív interakciót megértsük, a lokációkhoz rendelt jelentéstartalmakat és az ebből 
származó aktivitás valós/virtuális folyamatait definiálni tudjuk. (vö. Cséfalvay 1990, p. 90.) A pszichológia eredményeinek bevonására az a hipotetikus feltevés ad késztetést, hogy az infokommunikációs technológia földrajzi gondolkodásunkra gyakorolt hatásának jelenségére adható magyarázatok egy része a kognitív pszichológia bugyraiban rejlik, s úgy tünik, egyes elméleteivel azok megmagyarázhatóak. Az észlelés során környezetünkről kialakított képünk (mentális térképünk) az identitásunk alapja, amelynek markáns térbeli vetülete is létezik, kirajzolva valós és virtuális térbeli aktivitásunk keretét. ${ }^{204}$

A kognitív architektúrák közül kettő különösen érdekes a dolgozatom szempontjából, az egyik az úgynevezett szemantikailag áttetsző rendszer (SZÁR), a másik a párhuzamos elosztott feldolgozású folyamatok (PDP) rendszere. Andy Clark: A megismerés építökövei c. könyvében Paul Smolensky és Martin Davies hatására hivatkozva fogalmazza meg az áttetszö rendszerek (egyik) definícióját:

„Egy rendszert akkor nevezünk szemantikailag áttetszőnek, ha tiszta leképezés írható le a rendszer
viselkedésének szimbolikus (fogalmi szintű) szemantikai leírása, valamint formális számítási
tevékenységén belül reprezentált tárgyainak valamilyen kivetíthető szemantikai értelmezése között.”
(Clark 1996, p. 33.)

A PDP-rendszerek jellemzően szemantikailag nem áttetszőek. ${ }^{205}$ A szimbolikus megfeleltetés helyett az adatokat (az entitás információkészletének elemeit) igen hatékonyan és alacsony ráfordítással kezeli. A tartalmakat címkézi, nagy stressz és hibatürő képességgel bír, és csupán alapértelmezéseket rendel a dolgokhoz, ami által igen tág általánosításra képes. Jellemző még rá, hogy alapvetően emergens sémákat alkalmaz, amelyek hajlékonyságot biztosítanak PDP-rendszernek, mivel nem igényelnek komplex kész reprezentációs sémákat. $^{206}$

A két kiemelt kognitív architektúra szerepe igen fontos a környezeti észlelés szempontjából, hiszen ezek döntik el az abszorbeálható környezeti információ mennyiségét és minőségét. Az első, klasszikus felfogás sokáig uralkodó volt, s ahogy Clark fogalmazott, jellemzően arra vonatkozott, hogy „mit gondol az elme az elméröl”, míg a kognitív tudományok kortárs nézőpontja (Smolensky 1987²07, Clark 1996) szerint egyre sikeresebbek vagyunk az agymüködés megértésében és leképezésében, amit leginkább az információs technológia fejlődésével lehet igazolni. ${ }^{208}$ Igaz, hogy a kezdeti MI (mesterséges intelligencia) rendszerek a klasszikus szimbólum feldolgozásra épültek, de ezek jórészét átvette a PDP, és alapvetően konnekcionista felfogást követve a modern hálózatok elméleti alapja lett. ${ }^{209}$ 


\section{Kognitív geográfia, kognitív térképek?}

Ha valaki kognitív geográfiáról beszél, joggal felmerül a lehetőség, hogy azonosságot keressen a behavioristák mentális térképeivel. Megfogalmazhatunk ehhez hasonló analógiát, azonban tudnunk kell, hogy míg a mentális térképeknek létezik fizikai vetülete, addig a kibertér mentális térképezése kizárólag metaforikus reprezentációkon keresztül valósul meg. ${ }^{210}$ Igaz, ezeknek a metaforáknak viszont szükségük van tapasztalati észlelésre, különben a dolog nem müködik. A metafora, a két különböző világbeli entitás kapcsolata. A kognitív folyamatra koncentrálva az entitások, standard szimbolikus atomokként vesznek részt az észlelés folyamatában. ${ }^{211}$ Szemantikailag ezek egyszerü, szimbolikus mintaillesztést $\left(\mathrm{SZÁR}^{212}\right.$ ) követő folyamatok, $\mathrm{s}$ a bonyolultabb műveletekhez már más (pl. PDP ${ }^{213}$ ) architektúra szerinti operációra lesz szükség. Léteznek olyan azonosságon alapuló kategóriák/architektúrák, amelyek szemantikailag azonos kognitív térképezési metódust biztosítanak, lehetőséget biztosítva a valós/virtuális entitások paralelitását: az eseményekkel összhangban álló aktivitás, a fizikai objektumok hierarchiája az anyaguk szerint, a minőségi attribútumok, és a felhasználók szándékos akciói az aktivitás érdekében. ${ }^{214}$

Részletesebben kifejtve: a fizikai tapasztalati térből gyüjthető környezeti információk virtuális leképezésekor, és ha ezzel paralel a felhasználó szubjektuma is rendelkezik a szükséges attribútumokkal, lehetséges az információs tér kognitív térképezése. Ebben a térben is lehetségessé válhat, hogy a benne zajló események összhangban lesznek az aktivitással, az egyes objektumok anyagi hierarchiája fizikai természetük (pl. sürüség, tömeg, méret) szerint rendeződnek, és mindemellett rendelkeznek és hordozzák a kvalitatív (pl. színük, formájuk) jellegzetességüket. Nem utolsó sorban, ha a virtuális közegben zajló tevékenység tényleges aktivitásként jelentkezik, a döntéshozó és irányító a felhasználó lesz. ${ }^{215}$ A legszemléletesebb ilyen virtuális környezet az internet, illetve a webes alkalmazások, mint például az e-learning, amely akár virtuális osztálytermek leképezésére is alkalmas, vagy a már említett virtuális világ közösségi szájtok, és a webes térképek. ${ }^{216}$ Az egyre kifinomultabbá váló webes technológiának köszönhetően a szövegek keresése és a térbeli manipuláció is egyre szélesebb körüvé válik és egyre több lehetőséget biztosít a felhasználók számára aktivitási terük kiterjesztésére. A kibertér kognitív térképezésének elemei, a virtuális tájképek, a virtuális térképek, és navigációs entitások, valójában a valós tér belső és külső kognitív térképei. Ahogy Golledge-re hivatkozva Mei-Po Kwan is írja cikkében:

\footnotetext{
“A konfigurációs térismeret kialakulásához szükséges helyzet, távolság és irány ismerete, valamint az útvonal alapú térismeret kialakításában nélkülözhetetlen szokásos mozgásminta nélkül a kibertér egy megérthető kognitív térképe nem hozható létre (Golledge, 1995; 1999).” (Kwan 2001, p. 26.) ${ }^{217}$ - fordítás tőlem ${ }^{218}$
} 
A „virtuális világok” kognitív észlelésénél a folyamatos interaktivitás és hálózati kapcsolat mellett léteznie kell egy fizikai realitást szimuláló környezetnek is. Erre utalt a korábbi osztályozás és az idézet is. Akkor jöhet létre a tér észlelése, ha az minél inkább realisztikus, az alapvető földrajzi térkategóriák és irányok szerint bejárható, és a bejárási útvonalak tájékozódást segítő entitásokhoz, objektumokhoz köthetőek, és stabilitást mutatnak, vagyis megismételhetők. Valójában az észlelés során ebben a térben is földrajzi élményre, a környezet aktív birtokbavételére számítunk, akkor is, ha a virtuális dimenzió gyakran nagyon hasonló egy digitális térképre. ${ }^{219}$

Kwan (p.27.) egyébként Conklin és Kahn munkáira hivatkozva több alapvető problémát is kiemel a kognitív „kiber-környezetek” karaktere szempontjából, amelyek összhangban vannak az én kutatási és oktatási tapasztalataimmal is. ${ }^{220}$ Az egyik a disz-orientáció, a másik a kognitív túltöltődés. ${ }^{221} \mathrm{~A}$ disz-orientáció, vagyis a téri tudatosság zavara egy jellemző tünete a kibertér észlelésében keletkező rendellenességnek, amikor az első fázisban nem a fizikai térreprezentáció mentális eleme hiányzik, hanem az a szükséges tudati interfész, amely egyrészről virtuális reprezentációs tapasztalatokat tárol, másrészről adja a metódust, az előismeretet azok asszociatív használatához. Ezek hiányában könnyen bekövetkezik a mentális túltöltés. A túltöltődést, a túlcsordulást azonban elöidézheti a túlzott információgazdagság is, ahol a szelekció lehetősége csak a szofisztikált technikákkal rendelkezők számára adott, a többiek egyszerüen elvesznek a kibertérben (,getting lost in cyberspace”). A kettő együtt, a disz-orientáció és a rendezetlen információtömeg komoly mentális erőfeszítéseket követel az észlelőtől. ${ }^{222}$ Kwan kiválóan modellezte az individuális észlelő (humán entitás) és a kibertérben bejárható „környezet-halmazok” („the opportunity environment in cyberspace”) közötti kapcsolatot, és már ő is hangsúlyozza a kapcsolathoz szükséges interfészt.

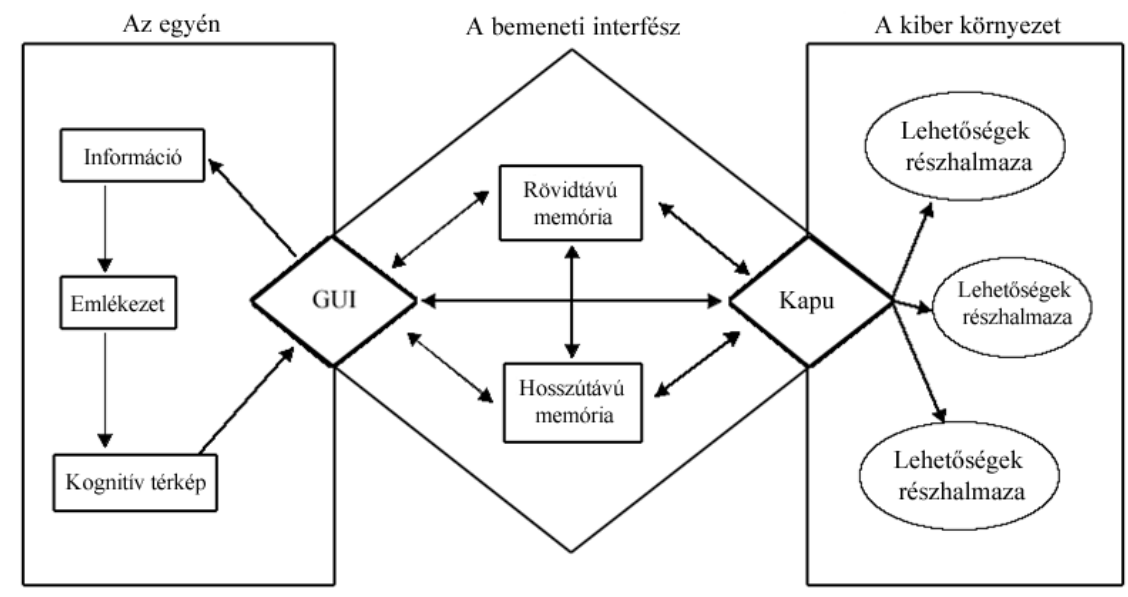

10. ábra. Az egyéni hozzáférés konceptuális modellje a kibertérben (megjegyzés: a GUI, graphical user interface - grafikus felhasználói interfész) (Kwan 2001, p. 28.) - forditás tölem 
Kwan említett munkájában a modell multi-dimenzionalitása mellett több kognitív magatartási dimenzióra is ráirányítja a figyelmet, amely a később bekapcsolódók hozzáférésével kapcsolatos, és egyáltalán nem az információ technológia függvénye, ellenben hangsúlyozza:

„... hogy az információforrások elérhetősége a kibertérben nem csak az összekötő eszközök és szolgáltatások hozzáférhetőségétől, hanem a személy navigációs és keresési segédeszközökre vonatkozó ismereteitől és képességeitől is függ. [...] elismeri a személyes tényezőknek vagy körülményeknek a kibertérbeli források egyéni hozzáférhetőségének befolyásolásában rejlő jelentőségét. Ezek közé tartozik a nem, faj, életkor, jövedelem, az összekötő eszközökre vonatkozó előzetes képzés vagy ismeret, valamint az offline információforrások elérhetősége és felhasználása (mint például nyomtatott anyagok vagy munkatársaktól származó információk).” (Kwan 2001, p. 28-29.) - fordítás tőlem²23

\section{Kognitív geográfia, az ismételt bünbeesés}

A földrajzi információk összegyüjtése, megértése és elsajátítása egyre inkább attól függ, hogy az egyén milyen alapvető információkezelési technikákat ismer. A kognitív geográfia a pszichológia aktuális, a kibernetika paradigmájával releváns eredmények szintézisével tesz kísérletet arra, hogy a behavioristák eredményeire építve a technológia által létrehozott virtuális terek észlelését, mint virtuális környezetészlelést leírja. Az abszolút földrajzi környezetben megismerhető térbeli objektumokhoz képest (ahol valamennyi érzékszervünk egyszerre fogadja be és dolgozza fel az információkat) itt elsősorban az agyi müködés által stimulált percepciók müködnek. A belső reprezentációkban történő tárolás, feldolgozás, adaptáció során kialakult sémák tükröződnek vissza az egyéni reprezentációkban, és azok feldolgozott publikációiban. ${ }^{224}$ Az információs technológiák arra késztetnek bennünket, hogy standard és egyéni humán interfészeket fejlesszünk ki annak érdekében, hogy az információs társadalom aktív és ne szenvedő polgárai lehessünk. A kognitív geográfia arra tesz kísérletet, hogy felderítse ennek a földrajzi megismerésre és a térbeli magatartásra (tájékozódás, napi aktivitás) vonatkozó összefüggéseit.

Az előző fejezetben tárgyalt paradigma miliő, az információs társadalom valós és virtuális tér értelmezései és néhány, a miliő megragadása szempontjából lényeges tipológiai megközelítés után most azt kell górcső alá vennünk, hogy a térbeli kognitív tevékenységünk miként illeszkedik az információs társadalom duális térkonstrukciójának a keretébe. Lesznek különbségek, amelyeket fel kell fedeznünk a hagyományos és az infokommunikációs technológia által befolyásolt kognitív folyamatok között, melyekből eltérő információkészletek generálódnak, és az egyes entitások között jelentékeny funkcionális és aktivitási különbség lehet. A tér észlelése mint információ felvétel (Cséfalvay 1990, p. 71.) 
egyáltalán nem egyszerü feladat, és ezen a helyzeten az elektronikus adat és információ áradatot közvetítő információ technológia egyáltalán nem segített rajtunk, sőt egyeseket már a kétségbeesés felé sodor, képtelenek lévén feldolgozni a körülöttük lévő információkat. A környezeti információk észlelése, ebbe beleértve a teljes észlelési, feldolgozási és reprodukciós folyamatot, azért fontos kérdés, mert, ahogy már láthattuk, az általa összegyüjtött információkészlet számos egyéni és csoportszintü funkciót ${ }^{225}$ meghatároz, végső soron hatással van térbeli aktivitásunkra is. Az infokommunikációs technológia által kreált (mobil és rögzített ${ }^{226}$ ) terek nehezebbé tették az észlelés folyamatát, mert a „zajszürés” nem mindenkinél müködik tökéletesen, és azoknak sem lett könnyebb a dolguk, akik információt szeretnének közölni, továbbítani, mert nekik olyan metódusokat kell kifejleszteni, amelyekkel célirányosan képesek az információt oda juttatni, ahol az hasznosul, ahol abból profitálhat küldő és a címzett is. ${ }^{227}$ A tér észlelési folyamatáról mint információ felvételi mechanizmusról már esett szó a kiberterek osztályozása kapcsán. Kellerman (2007) hármas felosztásával szemben Cséfalvay (1990, p. 71.), részben mint behaviorista kritikát, Harvey $(1981)^{228}$ két alapvető forrására hívja fel a figyelmet. Az egyik a közvetlen információszerzésből származtatott „signal sign-process”, melyet a közvetlen észleléssel szerezzük be, míg a másik az ún. „symbol sign-process”, amely közvetett információkat hordoz magában. A két osztályozást az alábbi táblázat foglalja össze:

\begin{tabular}{|c|c|c|c|}
\hline Kognitív osztály & Kulcs elemek (1) (2) (3) & Kellerman $^{229}$ & Harvey $^{230}$ \\
\hline Elsődleges & $\begin{array}{l}\text { feldolgozás sebessége (vizuális, } \\
\text { tipográfiai, földrajzi, társadalmi, jogi } \\
\text { stb.), adoptáció/abszorbeálás képesség, a } \\
\text { feldolgozás metódusa (SZÁR, PDP, } \\
\text { lineáris) }\end{array}$ & $\begin{array}{l}\text { Elsődleges személyes } \\
\text { tértapasztalat }^{231}\end{array}$ & Jelzés jel-folyamat $^{232}$ \\
\hline Másodlagos & $\begin{array}{l}\text { generalizáció, beolvasási sebesség, } \\
\text { szürési technika }\end{array}$ & $\begin{array}{l}\text { Másodlagos személyes } \\
\text { tértapasztalat }^{233}\end{array}$ & $\begin{array}{l}\text { Szimbólum jel- } \\
\text { folyamat }^{234}\end{array}$ \\
\hline Harmadlagos & $\begin{array}{l}\text { sémaképzés, reprocesszálás, előhívás } \\
\text { sebessége, feldolgozási metódusok } \\
\text { kombinatív képessége, tér-kompetencia }\end{array}$ & $\begin{array}{l}\text { Térbeli megismerés (egy } \\
\text { adott területről származó } \\
\text { ismeretek együttese) }\end{array}$ & - \\
\hline
\end{tabular}

4. táblázat. Észlelési osztályok összevetése Kellerman és Harvey esetében (a szerzöösszeállitása, kiegészítése a kognitív folyamatot közvetlenül befolyásoló kulcs elemekkel)-fordítás tôlem

Két alapvető észlelési osztály megfeleltethető Kellerman első két észlelési csoportjának, azonban Harvey, és lényegében Cséfalvay sem említi a harmadlagos, szubjektív reprodukción alapuló osztályt, amelyet Harvey analógiáját követve „interior sign-process”-nek 
nevezhetnénk. Bárhogy is nevezzük, a harmadik, az első kettő rövidebb-hosszabb időtávban szubjektíven újraértékelt információkészlete rendkívül fontos, mert az észlelési ciklus kezdőpontját határozza meg. Erről a kezdőpontról, vagyis az előzetes ismeretekről, létező belső környezeti reprezentációkból állítjuk elő azokat az új sémákat, amelyek a további észlelési ciklusokban felhasználhatóak. Lehetetlenség minden nap, minden helyzetben a körülöttünk lévő információhalmazt újra befogadni és feldolgozni. Az információ technológia virtuális képi és tipográfiai tere ezért nyújt rendkívüli kihívást az agyunknak, és vélhetően ezért használnak az internetezők többsége rendszeresen csupán a honlapok egy szük körét. ${ }^{236}$ Geográfiai szempontból is ezért a tér észlelése egy szelekciós mechanizmus (Cséfalvay 1990, p. 74.), amely során megpróbáljuk szétválogatni a számunkra hasznos és haszontalan információkat.

Személyes és tudományos tapasztalatok azt mutatják, hogy az elsődleges (1) észlelés lesz az, amely a legtöbb releváns információt fogja hordozni. Relevánsat, de a legtöbbet is. A táblázatban szereplő kulcs elemek éppen ezért véleményem szerint a következők lesznek: a feldolgozás sebessége (vizuális, tipográfiai, földrajzi, társadalmi, jogi stb.), az adoptáció/abszorbeálás képesség, a feldolgozás metódusa (SZÁR, PDP, LDP). ${ }^{237}$ A feldolgozás sebessége a felhasznált eszköz/érzékszerv típusától és az észlelni kívánt környezeti objektum típusától/jellegétől fog függni. ${ }^{238}$

A feldolgozása tehát nem kevés agyi komputációt fog igényelni, éppen ezért fontos a generalizálás folyamata, amelyet a földrajzosok jól ismernek például a térképek, a GIS és társadalomföldrajzi folyamatok grafikai modellezése esetében is. A második (2) osztálytípusba tartozó kulcselemek éppen ezért jellemzően: a generalizáció, a beolvasási sebesség, és a szürési technika lesznek. Bármilyen másodlagos észlelési folyamat legyen is, nem jöhet létre aktív ciklus, ha az észlelő nem ismeri a generalizált jeleket, szimbólumokat. ${ }^{239}$

Az észlelés első és másodlagos formáit akkor vagyunk képesek hatékonyan kihasználni, ha egy harmadlagos (3) osztályt is bevezetünk, amely az elöző kettő speciális keveréke, és egyben az első kettő müködését alapjaiban befolyásoló tényezö. Jellegzetes kulcselemei szerintem: a sémaképzés, a reprocesszálás, az előhívás sebessége, a feldolgozási metódusok kombinatív képessége, és egy egyedi, az entitásra jellemző attribútum, a tér-kompetencia. Az egyedi tér-kompetencia nagyon leegyszerüsítve egy tér-olvasási kompetencia portfólió. Mindenképpen több képesség együttesére vonatkozik, és arra szeretném felhívni a figyelmet az általam kreált fogalommal, hogy az egyébként is összetett észlelési folyamatot, bármilyen térben is zajlik, tovább nehezíti a kibertér megjelenése, ahol a többidejüség, a multiprocesszálás és (a térbeli) multi-dimenzionálás az amúgy is paralel feldolgozási folyamatokat (PDP) újabb rétegekkel egészíti ki. Ezt, stabil tér-olvasási képesség nélkül igen nehéz kezelni. A kompetencia portfóliójába beletartozik számos térforma szimbólumrendszere és azok 
paralel feldolgozási képessége. ${ }^{240}$ Kiváló kutatási terület erre, az egyre terjedő e-learning keretrendszerek, és a hagyományos könyvtári tevékenységhez kapcsolódó elektronikus szolgáltatások vizsgálata, használatuk elfogadottságát, sikeres adaptációját és nehézségeit áttekintő kutatások. ${ }^{241}$ Az új jelenség önmagában nem lesz új, mert gyökerei mélyen nyúlnak az indusztriális társadalmak modernizációs harcába, inherens logikája következtében azonban olyan, a térdualizmusnak megfelelő adatgyüjtési mechanizmust ír alapvetően át, hogy az már a humán evolúció természetes határait feszegeti. A társadalmi-gazdasági evolúció az új jelenség előbukkanásáig igyekezett szinkronban maradni a humán evolúcióval. A jelenlegi fázisban egy kitörni vágyó technológiai forradalom az alkotói akaratlan fogyatékosságának köszönhetően a „fontolva haladók” útját kényszerül választani.

A sokáig parciálisan aposztrofált technológia inherens logikája a testi extenzió volt, amely alapvetően nem változott meg, a cél továbbra is ugyanaz: a humán manipulációs tér dimenzionális kiterjesztése. ${ }^{242}$ A technológia szerepe már nem részleges, a metódus azonban megváltozott, ez az a tapintható jelenség, ami dolgozatom szempontjából meghatározó. A manufakturális linearitást felváltja a paralel folyamatok modellje, egyszerre jelezve, hogy az információ-gazdag társadalom modelljét az információ-domináns modell váltja fel, és azt, hogy az információáramlás sebességének, mennyiségének (szimplán a technikai fejlettségnek köszönhetően) növekedésén túl annak feldolgozási módszerei is markáns változáson mentek keresztül. Igaz, hogy jelentős kauzalitás fedezhető fel itt is, azonban véleményem szerint az ezredfordulót követő társadalmi újrastrukturálásban, az agyi müködés manipulációjában eddigelé egyetlen technikai irányzat sem érvényesítette hatását ilyen markánsan, miközben képes egyesek előtt láthatatlanná is válni. Ez utóbbi képessége aztán végzetes kétségbeesést és tanácstalanságot okoz a használó és nem használók közötti kommunikációban. (Sinka 2005, 2006a, 2006c, 2007a, 2009b) A test gépi extenziójának hatását, és az ebből következő agyi „devalvációt” már Wiener is felismerte és igen neheztelő hangnemben írt erről:

\footnotetext{
„Talán jobban meg tudom világítani a jelenlegi helyzet történelmi hátterét, ha azt mondom, hogy az első ipari forradalom, a „sötét sátáni malmok" forradalma azt jelentette, hogy az ember karjai a gépekkel való versengésben elértéktelenedtek. Nincs olyan bérszínvonal az Egyesült Államok ásóval, kapával dolgozó munkásai részére, amely elég alacsony volna ahhoz, hogy fel tudná venni a versenyt olyan gőzásóval, mint egy exkavátor. A modem ipari forradalom hasonló módon devalválja az emberi agyvelőt, legalábbis az egyszerübb és inkább rutinszerü döntések területén. Természetesen, mint ahogy a szakképzett szabó bizonyos mértékben túlélte az első ipari forradalmat, ugyanígy a szakképzett tudós vagy a szakképzett adminisztrátor talán túl fogja élni a másodikat. Ha azonban elfogadjuk a második forradalmat, mint ami már jelen van, a közepes vagy éppen annál kisebb képességủ átlagembernek semmije sincs, amit eladjon, és amit bárki másnak érdemes volna pénzért megvenni.” (Wiener 1974, p. 74.)
} 
Itt nem csak a gépek, a technológia fejlődése következtében eltünő munkahelyekről van szó, hanem arról a folyamatról is, amellyel az ember igyekszik minél hatékonyabban saját elképzelései szerint alakítania a környezetét, és akarva akaratlanul formálja társadalmát is. A történészek ezt nevezik: fejlődésnek. A társadalmi fejlődés azonban új utakra tévedt, rejtett dimenziók bukkantak fel, és a wieneri analógia szerint a modern infokommunikációs technológia is a jelentős agyi devalváció lehetőségét kínálja. ${ }^{243}$ Mindez persze azt sugallja, hogy a technológiai fejlődés nem viszi előrébb az embert, és az etológusok kijelentésével alliterál, miszerint semmilyen technológiai vívmány nem tette okosabbá az embert. Bár elsőre ez ellentétesnek tünhet a dolgozatom célkitüzésével, nem az. Az elméleti kutatásom célja nem az, hogy a technológia mindenhatóságát, vagy annak az emberi gondolkodásra gyakorolt kivételes és pozitív hatását hangsúlyozzam. A tézisem, miszerint napjaink modern infokommunikációs technológiája hatással van a társadalmi-gazdasági térben aktivitásukat végző emberekre, azok gondolkodásmódjára, aktivitási folyamataik tér-időbeli lefolyására. A technológia által keletkezett jelenség, a duális társadalmi-gazdasági tér, pedig speciális kognitív képességek kialakítását igényel: úm. a multi-dimenzionálás és a multi-processzálás képességét.

A társadalmi tér vizsgálati dimenzióinak egyik kiváló összefoglalását adja Kellerman The Internet on earth: a geography of information c. munkájában, melyet az alábbi tőle átvett ábra szemléltet. (Kellerman 2002b, p. 32.) A szociális tér összetett konstrukciója számos értelmezési olvasatot kínál, amelyek mentén a kibertér többrétegű dimenzionalitása, és benne annak társadalmi tere is kifejthető. A fizikai és a virtuális tér közötti kapcsolatot részben a technika, részben a társadalom biztosítja, melyek által a két tér külön-külön vagy együttes észleléséből, tapasztalati megismeréséből, környezeti információinak összegyüjtéséből egy entitás specifikus tudás aggregátum keletkezik.

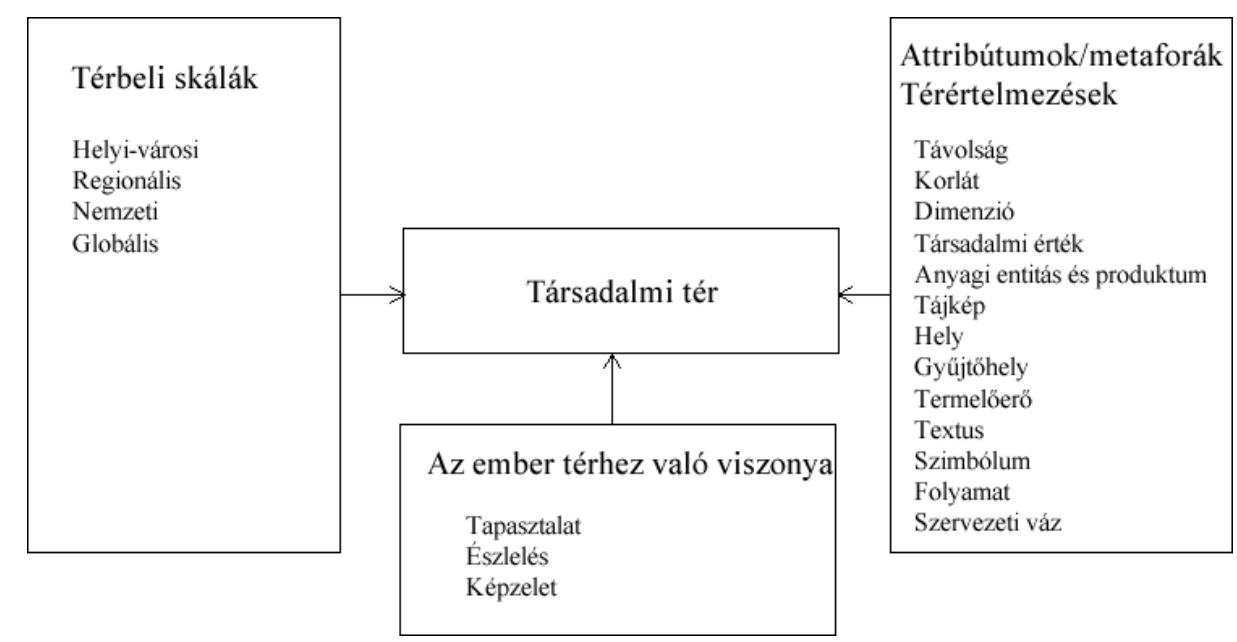

11. ábra. A szociális tér dimenziói (Kellerman 2002b, p. 32.)-forditás tölem 
A két tér összevetésének általam is elfogadott, a szoros interdependencia miatti egymásba ágyazottságot tükrözö kapcsolatrendszerét Kellerman könyvének egy másik ábráján szeretném szemléltetni. (2002b, p. 38.). Az információs társadalom dualista (hibrid) térkonstrukciójában zajló észlelési folyamatok tudati kapcsolatrendszerét bemutató ábra a két térkonstrukció eltérő, mégis egységes logikai rendszert alkotó észlelési mechanizmusát mutatja be. Az abszolút térből alkotott tapasztalati tér a fizikai térből származó információk újraformálásából származik. A meghatározott és hozzárendelhető belső folyamatok (processzek): az áramlások, transzferek és interakciók lesznek, és az észlelő különféle processzálás eredményeképpen tapasztalati tér-reprezentációs sémákat alakít ki. A térreprezentációknak itt van materializált vetülete. A kibertér, a virtuális kódok és különféle egyéb (fizikai reprezentációs tapasztalatokra épülő) ismeretek alakjában ölt testet, s ennek megfelelő észlelési mechanizmusokon megy keresztül. Immateriális jellege miatt tisztán konstrukciós-tereknek is nevezhetjük őket, mivel kizárólag az információs technológia által stimulált térkompozícióról van szó, a reprezentációknak itt immateriális vetülete van. ${ }^{244}$ Rendkívül fontos szerepet kapnak az itt zajló belső folyamatok: a kódokból és előzetes ismeretekből konstruálódó, reflektálódó tér-reprezentációk, illetve az egyes reprezentációkból származtatható terek alkotják a kapcsolatot a fizikai térrel. Nélkülük nem lehetnénk képesek az absztrakt tér megfogalmazására, nem léteznének erre alkalmas metaforáink. ${ }^{245}$ A szociális tér keretében kibontakozó valós és virtuális tér belső kapcsolatrendszere Kellerman szerint:

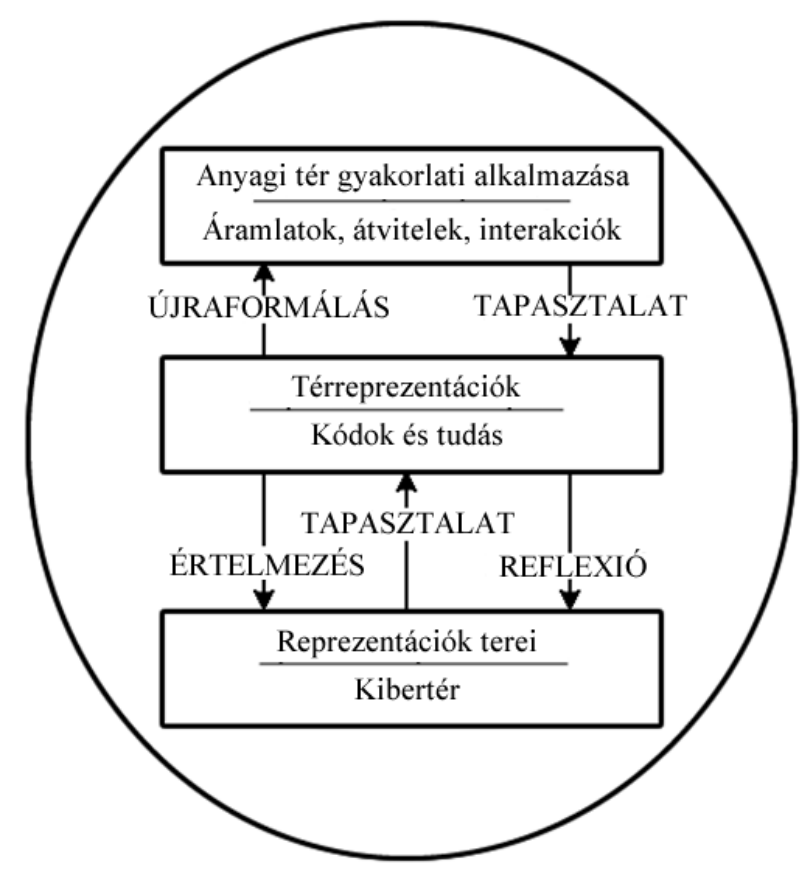

12. ábra. Kapcsolatok a valós és virtuális terek között (Kellerman 2002b, p. 38.) - forditás tölem. 
A két tér együttesen alkotja az információs társadalom terét, egymással szoros együttmüködésben létezhetnek csak, a végeredményül kapott kép (belső reprezentáció) azonban egyénenként különböző lesz. Az ok, az egyes terek eltérő észlelési folyamata és az entitások specifikus tudás aggregátumának különbözősége. Ráadásul ez a tudás a hálózatok specifikációját is figyelembe véve „a kapcsolatok mintázatát képviseli. Minden tudásunkat a világról csakis a kapcsolatok reprezentálják, semmi egyéb „tudás” nincsen.”246 (Pléh 1997, p. 38.) Mindez együtt igen sokszínű információs társadalom képét vetíti elénk, s ha ehhez hozzávesszük a földrajzi információk keresését, megjelenítését támogató webes alkalmazások exponenciális növekedését, akkor könnyen megérthetjük, hogy ugyanarról a dologról mennyire eltérően nyilatkozhat két ember/csoport. Nem politikai, vallási, etnikai véleménykülönbségekre, hanem közvetlenül a földrajzi környezet észlelése során begyüjthető információk alapján módosuló információkészletre gondolok. Klasszikus szakmabeli hasonlattal élt a behaviorista forradalom kapcsán Cséfalvay:

\footnotetext{
„A térbeli környezet egészen másként fest a párnázott hivatali ajtók mögül vagy a tervezőasztalról nézve, mint a templomtorony tövéből szemlélve. A nézőpontok azonban nem csak az észlelés eltérő perspektíváit mutatják, hanem a különböző szintủ problémaérzékenységre is utalnak. Az ilyen szélsőséges nézőpontok és probléma-észlelések, köztudottan nehezen egyeztethetők. Ha van társadalmi küldetése a „behaviorista-földrajznak”, akkor az éppen az, hogy e téren hathatósan segítse a társadalmi konszenzus kialakulását.” (Cséfalvay 1990, pp. 148-149.)
}

Azok között, akik látják és használják a kibertér dimenzióját, és aki nem, mindig markáns különbség, szociológiai tanulmányok szerint, digitális szakadék lesz. Az infokommunikációs technológia felgyorsította az információk összegyűjtését, újrafeldolgozását és publikálását. A domináns, az eddigiek tükrében az információkezelés technikája lesz, a metódus, ami a paradigma miliőjének belső folyamatait meghatározza. Végső soron az lesz a meghatározó, hogy az egyes dimenziókban ki milyen észlelési kompetenciával rendelkezik, milyen metodológia mentén végzi el a környeztében lévő információk adaptációját: evolúciós, technikai és/vagy tudás-kompetencia alapján.

Az evolúciós észlelési kompetencia egy makroszkopikus jelentéstartalmú vizsgálódás esetében nem bír jelentőséggel, éppen ezért a későbbiekben, még a hálózati logika áttekintése előtt, csupán a feldolgozási folyamatok szempontjából esik szó róla. Azt fogom Andy Clark filozófus segítségével a kognitív pszichológia területéről a vizsgálódásaim körébe vonni, ami kellően megtámogatja a hálózattal kapcsolatos feltevéseimet, és a térbeli gondolkodásunk evolúciós alapjait, fejlődésének lehetőségeit és korlátait is feltárja. Hipotézisem szerint ugyanis az információs társadalomhoz kapcsolódó, áthidalhatatlannak tünő negatív fogalomrendszerek, mint például a digitális szakadék, a digitális írástudás kompetencia 
hiánya, vagy az általam aposztrofált humán interfész-nélküliség gyökere kognitív fejlődésünkben rejlik, természetes gátat szabva a féktelen technokratizmusnak, és stabil medret kínálva egy magabiztos térbeli aktivitáshoz.

A technikai kompetencia elvben mindenkinek adott, ami a gyakorlatban nem igaz, mert jelentősen függ a társadalmi státusztól. Alaphipotézisként elfogadott, hogy az alacsonyabb jövedelmű rétegek nem engedhetik meg a drága eszközök megvásárlását, a szélessávú internet hozzáférés kiépítését. Mindez azonban csak általában igaz. Az empirikus kutatások arra a megdöbbentő eredményre jutottak, hogy az IKT eszközök beszerzése nem jövedelem, iskolázottság, hanem érdeklődés és felhasználói kompetencia kérdése. Ahogy Rigler András fogalmaz: „Az információs társadalom kialakulása érdeklódés hiányában elmarad.” ${ }^{247} \mathrm{Mi} \mathrm{ez}$, ha nem kompetencia hiány? Nem a technológia lesz ugyanis kizárólagos oka annak, hogy egyesek érzékelik, mások nem az információs társadalmat. Egyesek képesek lesznek a fától az erdőt is meglátni, vagyis a technokrata információs társadalom analógia helyett, egy belső működés és szerveződés szerinti komplexebb látásmódot elfogadni. Tény, hogy a jelenség oka, miszerint egyesek számára ez a társadalmi forma/átalakulás láthatatlan, abból ered, hogy szervezetében, mozgási dinamikájában és a felhasználók dimenziójában markáns különbségeket hordoz magában (lásd alább Kellerman tipológiáját). Ezt egy lépésből a kognitív evolúciónk nem képes áthidalni, idő kell neki. Az időt pedig a kompetencia fejlesztése, vagyis a tanulás és nem valamiféle természetes vagy mesterséges maturáció jelenti, ezért van jelentősége a tudás kompetenciájának, sőt hipotézisem szerint ez az elsődleges dominancia, míg az első kettő standardizálható, és makroszkopikus léptékben közel állandónak is tekinthető. Mielőtt azonban a tudás felértékelődéséről értekeznénk, tekintsük át Kellerman kiváló összefoglalása alapján a virtuális és valós tér közötti hasonlóságokat és különbségeket az alábbi táblázat alapján. ${ }^{248}$

Valós és virtuális terek

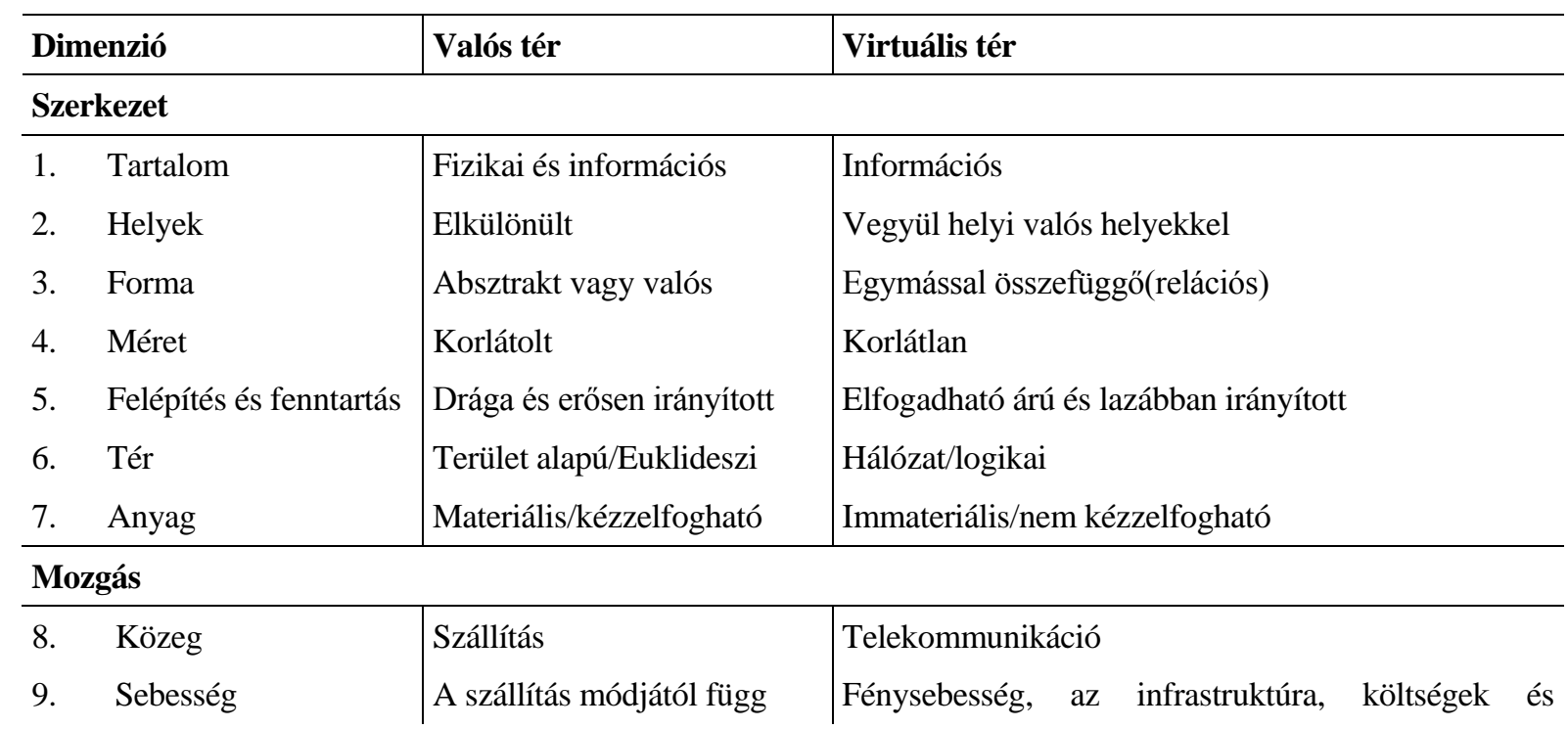




\begin{tabular}{ll|l|l} 
& & & szabályozások korlátozzák \\
10. & Távolság & A legfőbb korlát & Általában nem számít \\
11. & Idő & Számít & Számít, de az események felfüggeszthetők az időben \\
12. & Irány (orientáció) & Számít & Nem számít \\
\hline
\end{tabular}

Felhasználók

\begin{tabular}{ll|l|l}
\hline 13. & Személyazonosság & Meghatározott & A valós térbeli személyazonosságtól független \\
14. & Élmény & Testi & Képzelt és metaforikus \\
15. & Interakció & Testi & Nem testi \\
16. & Magatartás/attitüd & Hosszú távú elkötelezettség & Nem elkötelezett \\
17. & Nyelv & Nemzeti-belföldi & Többnyire angol-nemzetközi
\end{tabular}

5. táblázat. Valós és virtuális terek összehasonlítása (Kellerman 2007, p. 12.) - forditás tölem. ${ }^{249}$

A tudásbéli kompetencia rendkívül összetett, mint a többi dimenzió természetesen, de a szubjektum miatt, talán még ingoványosabb terület, mint az előző kettő. Úgy vélem, hasonló a helyzet, mint mikor a geográfia a szociológiát, majd a pszichológiát hívta segítségül, hogy önmagát jobban megérthesse. Csak ehhez a „bünbeeséshez” már nem csak a modern pszichológia eredményei, de az informatika és a pedagógia aktuális szintézise is szükségeltetik. Éppen ezért ha megnézzük Kellerman tipologizált dimenzióit a valós és virtuális terek összevetésében, akkor az identitás, a közvetlen tapasztalat, az interakció, az aktuális attitüd és a nyelv dimenziói a leghangsúlyosabbak a felhasználók aspektusában.

Egyetértve Kellerman tipológiai felosztásával, és hangsúlyozva, hogy ezek inkább olvasatok, mint kibontott tipológiai rendszerek, a kognitív földrajz keretében azokra a dimenzionális összetevőkre szeretném ráirányítani a figyelmet, amelyek a tudáskompetencia szempontjából a kognitív disszonancia hatását kelthetik. ${ }^{250}$

Az ilyen hatások első helyén áll a fizikai identitástól független virtuális identitás, amely lényegében a meglévő virtuális sokszorozása. ${ }^{251}$ A közvetlen (fizikai) tapasztalat nélküli, testetlen térben nem jöhetnek létre azok az észlelési tapasztalatok és belölük a reprezentációk, amelyek addig nem jöttek létre a fizikai térben. Ahogy korábban Kwan (2001) is utalt rá, szükség van tehát előzetes tudásra, hogy tisztán vizuális, tipográfiai (a textushoz köthetö) vagy egy szimplán auditív térben, vagy ezek bármely kombinációjában, a tapintási, szaglási, gravitációs, háromdimenziós tér nélkül, bármiféle mentális reprezentációra, térhez köthető fogalmi asszociációra képesek legyünk. A kognitív disszonanciát valójában az észlelt környezeti információ intenziója és extenziója közötti interfész nélküliség adja. ${ }^{252}$ Szándékosan használom itt az interfész-nélküliséget, mert a virtuális környezet észleléséhez szemantikailag áttetsző szimbólumrendszerek sorozatán keresztül jutunk el, első lépésben. Ha hiányzik a tapasztalati terünkből, vagy nem sajátítottuk el kellöképpen a saját nyelvi 
kontextusunkban a fizikai tér földrajzi fogalomrendszerét, akkor azt képtelenek leszünk leképezni, transzformálni a virtuális oldalon. ${ }^{253}$

\section{A KONNEKTIVIZMUS FÖLDRAJZA}

A konnektivizmus földrajza egy régi-új földrajzi irány, nem is akar más lenni, csak a helyét keresi abban a történetben, amelyet a geográfusok írnak a közlekedés földrajzától az infrastruktúra földrajzán keresztül a kommunikáció földrajzáig. ${ }^{254}$ Ha szorosabban megnézzük, akkor az infrastrukturális rendszerek között találjuk a hírközlést vagy a távközlést, mint a termelést közvetlenül támogató vonalas rendszert, és ami a legközelebb áll a hálózati társadalom alapinfrastruktúrájához. ${ }^{255}$ A termelői infrastruktúrákhoz sorolt távközlő eszközök és hálózatok, azonban az egyszerű pont-pont összeköttetésű, és alapvetően hangátvitelre kialakított hálózati modellel az ezredfordulóra okafogyottá és elavulttá váltak. ${ }^{256}$ A modern infokommunikációs technológiára épülő skálafüggetlen topológiájú hálózatok viszont már mind a termelöi, mind a szociális infrastruktúra aktív részesei, gyakorlatilag a kettő metszéspontjába kerültek. A gazdasági térben elfoglalt szerepük szolgáltatási és termelő oldalon is egyaránt jelentős, és kiemelt részesedésük van az innováció-technológiákból és a hozzá kapcsolódó innováció-centrumok (milieu of innovation) létrehozásában, müködtetésében is. ${ }^{257} \mathrm{~A}$ szociális vetületben pedig nem csak a technológia által hálózaton kínált szolgáltatások vehetők ide, hanem azok a társadalmi közösségi színterek is, amelyek jellemzően a már tárgyalt kiberterek specifikuma, tartalmi jellegzetessége. ${ }^{258}$ Ezt erősíti meg Abonyiné (2003, p. 25.), amikor a korábbi infrastruktúrális rendszereket ábrázoló modelljénél már mind a termelői, müszaki, technikai alrendszerben, mind pedig a szociális, lakossági, humán, települési alrendszerben megtaláljuk az utalást az infokommunikációs hálózatokra.

A konnektivizmus földrajza, a vonalas infrastruktúra hálózatok egyik speciális, modernkori emergens irányzata, amely több, addig alágazati szerepkört betöltő rendszert emel önálló vizsgálati területté. Úgy vélem, nem szükséges önálló szakági tudományterületként aposztrofálni, vagy sarkos paradigmaváltásra készülni, de érdemes észrevenni, hogy már a magyar geográfiában is igen hamar megjelennek a terület fontosságát kiemelő munkák. Példa erre Abonyiné 1995-ös és 2003-as forrásának összevetése vagy például Erdősi Ferenc (2005) így ír a Magyarország közlekedési és távközlési földrajza c. könyvének bevezetőjében: ${ }^{259}$

»[...] Akarva-akaratlanul ma szinte valamennyi cselekedetünk a tágabb (földrajzi) értelemben vett kommunikációról szól, mivel úgyszólván minden lépésünknek van valamilyen mértékü és természetü közlekedési/távközlési/infokommunikációs vonzata. [...] Az egyoldalú gazdaságföldrajzi szemlélet a 
kommunikációt a gazdasági élet „szolgálóleányává" degradálta. Azonban maga a közlekedés sem csupán „mozgásba hozott gazdaság", nem csak segítő eszköz az anyagi természetü helyváltoztatási igények szolgálatában, hanem az innovációk terjedésének, a civilizációs-kulturális vívmányok használata térbeni terjedésének az eszköze is, amely (egyre inkább a távközléssel, infokommunikációval együtt) már jó ideje a szellemi értékek közvetítője is. [...] A közlekedés és távközlés ma már nem csupán a többi ágazat kiszolgálója, hanem egyre inkább a gazdasági/társadalmi folyamatok vezérlő művének (,irányítópultjának") szerepét is betöltve olyan önálló ágazattá nőtte ki magát, amely a gazdasági növekedésben nagyra értékelt húzóágazatként a „kommunikációs behálózottsággal" Magyarországon is lehetővé teszi a mobil, illetve az információs társadalom kialakulását.”

Erdősi nem csak céloz rá, de meg is fogalmazza, hogy a kommunikációs hálózatok újraszervezik a gazdasági kapcsolatokat, önálló szervezőerővel rendelkeznek, s lényegében a kibernetika, mint „irányítópult” és vezérlőegység a társadalmi kapcsolatrendszert is átformálja, kialakítva a számára legmegfelelőbb konstrukciót: az információs társadalmat. A társadalmi konstrukcióelméletekhez kapcsolódó szemlélete később is érezhető:

» [...] a kommunikáció nem csupán a térségek közötti gazdasági feszültségek mérséklésére képes, hanem minden korban befolyást gyakorolt az etnikumi, vallási, kulturális struktúrák, valamint a politikaiigazgatási téralakzatok kialakulására és fejlődésére. [...] a gazdasági/társadalmi teret egyelőre még nehezen kiismerhető módon strukturáló, egészen sajátos tértextúrája szemünk előtt bontakozik ki, [...].” (Erdősi 2005)

Itt még áttételesen jelenik meg az infokommunikációs hálózatok térformáló hatására történő utalás, a szerző elsősorban az úthálózat, és kiemelten a vasút történelmi hatását fejtegeti a bevezetőjében. Markáns különbséget azonban nem tesz, sőt az információáramlással a közösségek közötti információkészlet átadásának fontosságát erősíti meg, összhangban azzal, amelyet korábban a társadalom evolúciós modellek, az információkészlet és a manipulációs tér kapcsán fejtegettem. Véleményem szerint a közlekedési és távközlési földrajz elnevezés mára már nem elég szofisztikált, s talán a konnektivista földrajz plasztikusabban és a tartalmára is közvetlenebbül utaló módon jelölne egy modernebb irányzatot, visszatükrözve a hálózati társadalom képét. Mindenesetre vitathatatlan, hogy a hálózatok tértextúrára gyakorolt hatását Erdösi is elismeri, és hangsúlyozza a kommunikáció szerepét az egyéni, csoportos és társadalmi szintü információcserénél is, illetve ezek közvetett hatására utal a közösségi téralakzatokra, a „sajátos tértextúrájára” vonatkozóan.

Erdösi Ferenc idézett szavait azért tartottam fontosnak a konnektivizmus földrajza bevezetőjében tárgyalni, mert a benne leírtak véleményem szerint tökéletesen korrelálnak a geográfusok eddig megkezdett munkáival, és illeszthetők a dolgozat által vállalt diskurzusba csatlakozás egyik lényegi elemeként. A konnektivizmus földrajza annak az útnak a modern 
kori szakasza, amelyet az említett geográfiai irányzatok a hálózatokkal kapcsolatban megkezdtek. A legelemibb közlekedési úthálózatoktól napjaink infokommunikációs szupersztrádájáig az összekötő gondolat: a konnekció. Ez a konnekció jelenik meg a modern kognitív pszichológiai eredményekben (Smolensky 1987, Clark 1996, Pléh 1997, 2002), a hálózatok kutatásának aktuális publikációiban (Barabási-Albert 2003) és nem utolsó sorban az információs társadalmat kutató geográfusok munkáiban is (Nagy és Kanalas 2003, 2009, Sinka 2005, 2007b, 2008, 2009, 2011a).

\section{Konnektivizmus, útban a szintézis felé}

Az információs társadalom maturációs szakaszában a konnektivizmus lesz a szintézise és az egyik legfontosabb részparadigmája a kibernetika által szervezett társadalmi alakulatnak. Manuel Castells alapműve, az Információ kora, mintegy dokumentálta azt a tényt, hogy az információs társadalmakat megalapozó technológiai hálózatok megváltoztatják a globális világ gazdasági és politikai tereit. Az áramlások tere (space of flows) már egyszerre utópisztikus és realisztikus. ${ }^{260}$ Castells munkájában amellett érvel, hogy az áramlások tere nem öleli fel az ember teljes tapasztalati terét, mert az emberek jellemzően lokalitásfüggők, laknak valahol, éppen ezért a saját lokalitását mindenki helyhez kötöttnek, rögzítettnek érzi. (Castells 2005, p. 546.) Az utópia ott jelentkezik, hogy mindez képes megváltoztatni az egyén lokális identitását, csupán azzal, hogy hálózatba kerül és hálózati logika szerint épül fel körülötte a társadalom. Ennek ellent mond az egyén lokális identitása, amelyet már korábban tárgyaltunk Kellermannál, ${ }^{261}$ és vitatja maga Castells is, mikor az egyén lokalitásfüggőségéről beszél. Az ellentmondás azonban nem paradoxon, inkább realitás, mert a konnektivizmus (a globális rendszerek „beszivárgása által”) éppen ezeket a helyeket kapcsolja össze. Castells utópiája csak számunkra volt utópia az ezredfordulón, napjainkban nekünk is valóság.

\section{Konnektivizmus: földrajzi vagy oktatási paradigma?}

A tradicionális struktúrák újragondolását részben maga a technológia, részben a technológiákra épülő eszköztár kényszeríti ki. A hálózati társadalom új oktatásparadigmájának, a konnektivizmusnak a földrajzi aspektusú vizsgálati módszereit áttekintve egy lehetséges megközelítési módot kaphatunk a téma tárgyalására. Természetesen maradhatnánk a klasszikus infrastrukturális megközelítésnél, vagy felfedezhetünk a szakirodalomban új (neogeography ${ }^{262}$ ) irányzatokat is, de ahogyan az előző fejezetekben már láthattuk, nem a technológia dominanciája lesz a meghatározó, hanem a tudásszervezésé. 
A globális infokommunikációs hálózatok eszköztárára épülő konnektivista tanuláselmélet geográfiai szemléletű kutatása a tudástársadalom szerveződésének technológiai, tanulás-módszertani, valamint térszervezési folyamataira együttesen összpontosít. A technológiai aspektus őrzi a klasszikus infrastruktúrális vonalat, a tér dinamikájának vizsgálata sem idegen test a geográfiában, ami fejtörést okozhat: a tanulásmódszertanhoz kapcsolódó ismeretek beemelése. Miért is van erre szüksége a geográfiának? Nos azért, mert a hálózatra épülő gazdasági és társadalmi környezetben nem egyszerüen a szerkezet és a benne zajló folyamatok változnak meg, a változást elsődlegesen a már korábban is emlegetett módszer okozza. ${ }^{263}$ Persze nem tévedünk nagyon el, ha ezt megpróbáljuk a kulturális földrajz vizsgálati területéről megközelíteni, de annak csak egy szűk területe esik ide. ${ }^{264}$ A megfelelő metódus megértése, elfogadása és elsajátítása határozza meg a csoportnak és az egyénnek (mint a csoport tagjának) a hálózati társadalomban betöltött szerepét. ${ }^{265} \mathrm{Az}$ egyén mint szubjektum és mint entitás, igen fontos eleme a hálózati társadalmaknak, ő az, aki hordozza a tudást, ő az aki összekapcsolja a tudáselemeket akár erős, akár gyenge kapcsolatok formájában. Mint már tudjuk, az utóbbi sikeresebb. Ennek az elemnek a további sajátosságai közé tartozik, hogy sokféle formában van jelen, szerepe van a csomópontok összekapcsolásában, és magában hordozhatja a human interfészt, és az egyedi információt (self attribute), amely része a kollektív tudásnak, hatással van a csoport morfológiájára, így meghatározza a logikai-fizikai elhelyezkedést, lényegében felépíti a hálózati topológiát.

Mindehhez a technológia is jeletékeny segítséget biztosít, mert a külső (outsider) megközelítésben ${ }^{266}$ lassulni látszik és egyre erősebbé válik a funkcionalitás szerepe. A probléma azonban ott jelentkezik, hogy az információs társadalom értelmezési módjai közül a technológiai determinizmus nehezen enged teret olyan, számára megfoghatatlan területeken, mint a pedagógia, vagy a magatartástudományok. A statisztikailag nehezen számszerűsíthető, esetenként kizárólag a hatásmechanizmusukban, folyamataikban megragadható térindikátorok ${ }^{267}$ alkalmazása nem tartozik a geográfiai kutatások legkedveltebb módszertani megoldásai közé. Igaz, az említett mérési problémák lassan megoldódnak, hiszen egyre több matematikai formula születik a hálózatok, a kognitív tudományok kutatásával kapcsolatban. Bonyolultságuk azonban egyelőre nem teszi lehetővé, hogy valamennyit adoptáljuk a geográfia számára. A földrajz „bünbeesése” már önmagában is rontott ezen a helyzeten, lényegében inkább csak bonyolultabbá tette. Igaz, egyúttal újra rávilágított arra a tényre, hogy a geográfia egy speciális szintetizáló tudomány, amely éppen azokat az eszköztárakat ragadja meg a társtudományokból, amely a legjobban segíti a komplex folyamatok megértését, ráadásul ezzel az integrált szerepkörrel egyedi vizsgálati kontextusokat alakít ki. A hálózati társadalom új oktatás-paradigmájának, a konnektivizmusnak földrajzi aspektusú elemzéséhez 
ismételt bünbeesés szükséges ${ }^{268}$, és a lehetséges vizsgálati módszerek áttekintése egy újabb speciális eszköztárat igyekszik magába integrálni: a pedagógiai elemzés eszköztárát. ${ }^{269}$ A globális infokommunikációs hálózatok eszköztárára épülö tanuláselmélet beemelésével nem tünik el tehát a szintézis, csak új, a kor folyamatait jobban magyarázó elemekkel bővül. Annál is inkább így van, hiszen Wiener (1977) szavaira hivatkozva írja James $R$. Beniger Az irányítás forradalma c. könyvében, hogy a technológia általában újabb technológiát szül, majd így folytatja:

„[...] létrejövő újítások további újításokra teremtenek szükségletet az információfeldolgozási és kommunikációs technológiákban. A technológiai újítás egyre inkább kollektív erőfeszítéseket kíván, amelyeknek az eredményeit ismertetni és terjeszteni kell, ezért egyúttal növekvő igényt teremt a müszaki oktatásban és a kommunikációs rendszerekben az információtárolás és -visszakeresés új technikai eszközeinek a kidolgozására is, teljesen függetlenül az irányítással szemben megnyilvánuló sajátos igényektöl.” (Beniger 2004, p. 37.)

Miért van erre szükség? Az idézet alapján jól látható, hogy az oktatás, célzottan fogalmazva: a társadalmi homeosztázis érdekében elosztott információkészlet lesz a felelős. Az ok így abban keresendő, hogy a hálózatra épülő gazdasági és társadalmi környezetben nem egyszerüen a szerkezet, a strukturális felépítmény és a benne zajló folyamatok változnak meg, a változást főként a módszer hozza, az információátadás módszere. A hierarchikus elemek javarészt öröklődnek, sőt számos olyat is találhatunk, mint például az oktatási rendszer vertikális és horizontális struktúrája, amely a változások ellenére évszázados gyökerekkel rendelkeznek. A talapzat egyértelmüen földrajzi, lokalitáshoz rendelt, ahonnan, mint innovációs központból határozza meg konnekcióit és manipulatív terét. Ez a manipulatív tér áttételes, nem minden szakaszában kényszeríti ki a térbeli aktivitást. Ilyen például egy egyetem vonzáskörzete, beiskolázási tere, de ide kapcsolódhatnak a könyvtárakhoz is. (Sinka 2006d) A megfelelő metódus megértése, elfogadása és elsajátítása határozza meg a csoportnak és az egyénnek (mint a csoport tagjának) a hálózati társadalomban betöltött szerepét.

Az egyén mint szubjektum és mint entitás ${ }^{270}$, igen fontos eleme a hálózati társadalomnak. Ennek az elemnek a sajátosságai közé tartozik, hogy sokféle formában van jelen, szerepe van a csomópontok összekapcsolásában (technológiai és human interfész), egyedi információt hordoz (self attribute), amely része a kollektív tudásnak, hatással van a csoport morfológiájára, így meghatározza a logikai-fizikai elhelyezkedést, lényegében a hálózati topológiát. A hálózat, földrajzi értelemben, és lényegében technológiai értelemben is, akkor válik hálózattá, ha rendelkezik topológiával és az helyes. A helyes topológiának legszembetűnőb elemei: a folytonosság, a szomszédság, a csomópontiság, a hierarchia 
megléte, a számíthatóság és mérhetőség (kerület, terület, hossz), és a területi súlypont léte (topológia központ). A konnektivista topológia abban válik különlegessé, hogy a hagyományosan felépíthető földrajzi topológiákhoz képest ez állandó mozgásban van. A jelenség ábrázolására az időföldrajzi elemzések, illetve a GIS technológiára épülő szoftverek nyújtanak kiváló megoldásokat. ${ }^{271}$ Anélkül, hogy ezeket az elemzési módszereket részletesebben tárgyalnánk, érdemes röviden kitérni arra, hogy ez a mozgás alkalmanként, és ciklusonként új topológiákat épít fel. ${ }^{272}$ A ciklusok a másodperctől akár a több éves szakaszú időtartamig értelmezhetők maradnak és jellemzően önálló topológiai réteget képeznek a meglévő hálózati struktúrában. A ciklus időfüggőségét két aspektusból vizsgálhatjuk: valós idejű függőség és technológiai időfüggőség. A valós idejü függőség (VIF) konzisztens az entitás hálózati szerepkörével. Például egy diák adott iskolatípusban eltöltött idejével. Ez az időszak egy relatíve zárt függőséget hoz létre, és például életkorra, lakóhelyre vonatkoztatva térben többé-kevésbé kötött struktúrát eredményez, vagyis ez egy tér-idő kerettől függő rendszer. Plaszticitása részleges, inkább merev. A technológiai időfüggöség (TIF) az entitás térbeli pozíciója és a hálózati topológia szerint felépülö kapcsolati háló esetlegességéből származik. Például az említett diák napi, heti, vagy alkalmi mobilitásából és az iskola rögzített lokalizációjából fakad. A technológiai időfüggőség lényegében a valós idejű részhalmaza.

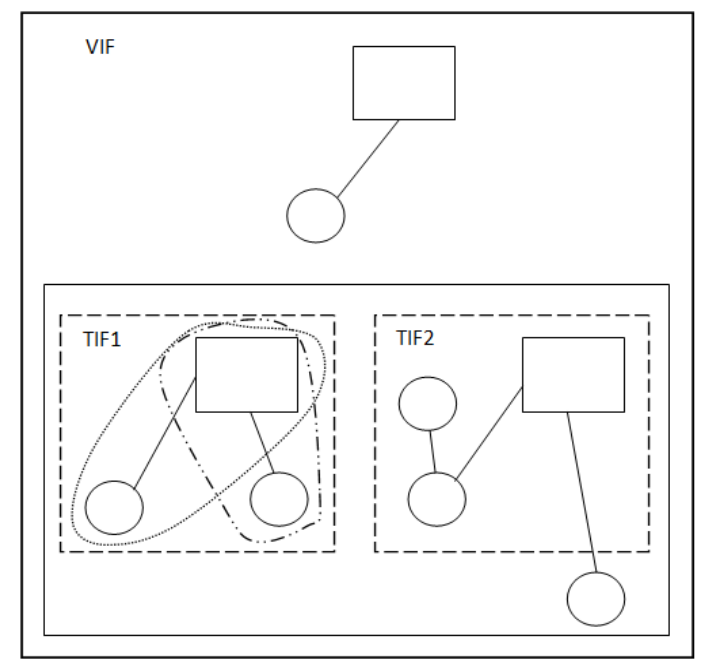

13. ábra. Az idófüggő és technológiafüggő hálózati topológia kapcsolata

A két technológiai függőség közötti különbséget a hálózati architektúra határozza meg: lehet szabályrendszerében kötött, de térben dinamikus, mint a TIF1, és lehet szabályrendszerében és térbeli elrendezésében is kötött (TIF2). Utóbbi estében jelöltem annak lehetőségét is, hogy a kötődés új (például felvételiző) vagy régi (alumni diák) is lehet, és akkor kívülről érkezik az első kapcsolatfelvétel, vagy már csak kifelé irányul. 


\section{A konnektivista földrajz kutatási területei}

Érdemes ennél a pontnál röviden összefoglalni a konnektivizmus geográfiát érintő területeit, s a további szintézis felé vezető úton egy pillanatra megállni. Ha meg kellene fogalmazni, mi is kerüljön a konnektivista földrajz kutatási területei közé, akkor az alábbi csoportosítások képzelhetők el.

\section{Technológia és térbeliség konnektivizmusa - a miliő diskurzusszintje}

A technológiai konnekció az infrastruktúra diskurzusszintje, mivel a konnektivizmus földrajzának technológiai hátterét az IKT eszközök adják, mint a kiberterek valós terét a fizikai hálózatok. Ahogy ezt már láthattuk Kellerman tipológiai olvasatainak tárgyalásakor is, ez nem alkot önálló téregységet, szerepe azonban meghatározó közvetve a társadalmi és közvetlenül a gazdasági folyamatokban. Ha ennek mentén kutakodnánk, az jelentősen leegyszerüsítené a problémakört, mint ahogy azt a technokrata információs társadalom megközelítések teszik. Ahogy azonban az információs társadalom diskurzus szintjeinél is felbukkannak más értelmezések, úgy a konnektivizmus tisztán technológiai szempontú elemzése sem lehetséges. A technológiai vetület elsősorban a módszertani támogatást nyújtó eszközpark kontextusában emelkedik ki, és hálózati logikát követ ${ }^{273}$, miközben a súlypont, ahogy azt az empirikus tanulmányok is igazolják ${ }^{274}$, itt és most is a módszertan marad, így a technológiai diskurzus átvezet a humán diskurzusra.

A térbeliség konnektivista megközelítése a dolgozat szempontjából egyértelműen az információs társadalom miliője lehet csak. A dolgozat előző fejezeteiben számos helyen részleteztem ennek a térbeli aspektusait, így itt csak annak közvetlenül a humán diskurzusszintre átkötő, és az oktatási paradigmát meghatározó aspektusára térnék ki.

Belátható, hogy az infokommunikációs technológiák elterjesztése, a gyártók támogatásával még nem old meg mindent. A kritikus tömeg-evolúcióhoz ${ }^{275}$ szükség van a (technikai mellett) a humán adaptációs készség lehető legmagasabb szintre történő emelésére, vagyis a premissza nem a technológia, hanem a tudás. ${ }^{276}$ Ahogy Castells fogalmaz: „Az Információs Korszakba való belépés sikere azon múlik, hogy az egész társadalom iskolázottá tehető-e, valamint, hogy képesek-e befogadni és kezelni a komplex információkat. [...] És mindez természetesen erősen kötődik a kulturális fejlődés teljes folyamatához, beleértve a funkcionális analfabétizmus szintjét, a média tartalmát és az információ szétosztását a nemzeten, mint egészen belül.” (Castells 1998). Ennek alapján megfogalmazható az a gondolat, hogy az információs társadalom stratégiák - mint pl. a Magyar Információs 
Társadalom Stratégia (MITS 2003) - elsőszámú kihívása egy adaptációs-rés leküzdése, illetve minimálisra csökkentése.

A probléma az adaptáció képességének hiányára, egyfajta humán-interfész nélküliségre vezethető vissza. Nem a tudás és/vagy információ központi szerepéről van már szó, hanem ahogy Castells fogalmaz: „a tudás és információ alkalmazása tudásgerjesztő és információfeldolgozó/kommunikációs eszközökre”. (Z. Karvalics 2002) Ebből adódódik, hogy „...az elmaradottság terjedéshiányos és befogadásképtelen állapotként azonosítható, s így megszüntetése egyszersmind a térbeli terjedés feltételeinek módosításával is összekapcsolható (e gondolatkörköz tartozó regionális politikai koncepció az ún. innovációorientált területfejlesztés).” (Mészáros 2000, p. 26.). Mindez az oktatási rendszer felértékelődéséhez vezet, így ,azok az országok lehetnek a folyamatok nyertesei, amelyek a legtöbbet invesztálják kutatás-fejlesztésbe, oktatásba és információs infrastruktúrába.” (Z. Karvalics, 2002, p. 74.) Véleményem szerint az adaptációs-rés (ISAG - Information Society Adaptation Gap) kifejezhető úgy is, mint az információs társadalom kritikus tömegpontja ${ }^{277}$ (ISCM) és az információs társadalom fejlettségi fokát mutató index (ISI) különbsége. Ha meg tudjuk, vagy inkább meg tudnánk ragadni az információs társadalom kialakulásához szükséges kritikus tömeg-evolúciónak azt a 'pillanatát', amikortól a társadalom úm. információssá válik, akkor képesek lennénk az adaptációs rés mennyiségi és minőségi meghatározására is. (Sinka 2004) Erre kísérletet is teszek a következő diskurzusszinten, a humán diskurzusszint tárgyalásánál.

\section{Konnektivizmus, mint a humán erőforrás diskurzusszintje}

$\mathrm{Az}$ adaptációs rést később humán interfész-résként (HIG - human interface gap ${ }^{278}$ ) definiáltam, és attól kezdve ezt a fogalmat használom rá. (Sinka 2006) Az ok egyszerü: az adaptációs rés inkább passzív befogadásképtelenségre utal, míg az interfész hiánya sejteti az illesztés lehetőségét, az információ átadása és abszorbeálása nem áthidalhatatlan rés, hanem csak egy eszköz hiánya. Ez az eszköz pedig az értekezés kontextusában nem más, mint: egy tudás-kompetencia portfólió. Ez a portfólió pedig tartalmazza mindazokat az illesztő programokat, amelyek a „szoftver” oldalon szükségesek: ${ }^{279}$ a hálózati tanulás ismeretei, az információkezelés alaptechnikái, a szelektív gyorsolvasás képessége, a stabil fizikai térreprezentációk virtuális leképezésének képessége, az alapvető földrajzi térfogalmak magabiztos használata, anyanyelvi és rendszerszintű (gépi) szemantikai megfeleltetés képessége, a stressztűrő multi-dimenzionalitás és multi-identitás menedzselésének technikája stb.. Bár a szükséges kompetenciák igen tekintélyes halmazával állunk szemben, a többségét egyetlen fogalom köti össze: a digitális írástudás. Ennek egyik legjobb megközelítését ma is a 
könyvtárosok adják, az American Library Association (ALA) ${ }^{280}$ készített erről korábban egy kiváló összefoglalást, melyet az amerikai felsőoktatási intézmények számára ajánlották. Napjainkban az Association of College and Research Libraries (ACRL) szervezete alatt folytatják a munkát. $^{281}$

A humán konnekció számos formájával foglalkoztam már az értekezés során. Az információs társadalom földrajzának tipológiai olvasataihoz kapcsolódóan már volt szó a humán erőforrásról, mint emberi diskurzusszintről. ${ }^{282}$ A konnektivista szemlélet igazán itt van elemében. Most anélkül, hogy nagyobb kitérőt tennék a digitális írástudás kompetencia részletes elemzésére, egy igen reprezentatív elemét azért szemügyre kell venni, mert a konnekcionista felfogás problémáját több szempontból is jól megvilágítja: ez a humán interfész hiánya. Kezdjük a diszkussziót egy ábrával, melyhez az adatokat a World Internet Projekt kutatási jelentései szolgáltatták. ${ }^{283}$ Az ábra valójában két adatsor összevonásából, pontosabban egyetlen grafikonban történő ábrázolásából született. Az egyik adatsor az internet használókat iskolai végzettségük szerint, a másik korcsoportuk szerint jeleníti meg. Egyetlen tengelyük közös, az életkor. Az életkor tengelyének korcsoport szerinti beosztása többé-kevésbé megfeleltethető az egyes iskolatípusokba járó tanulók korcsoportjával, ezért ha nem is tökéletes a fedés, az összevetésnek van alapja. (14. ábra)

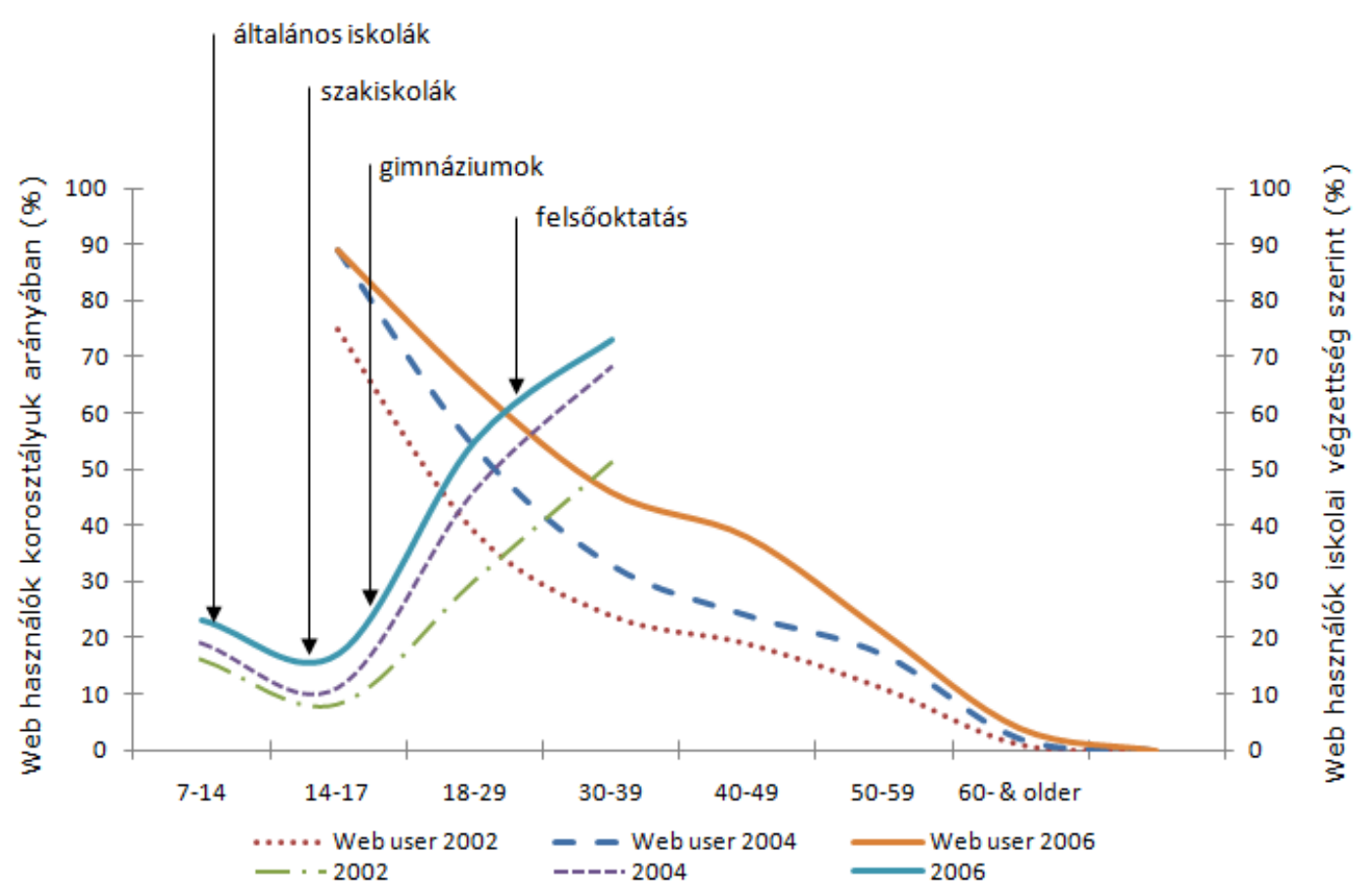

14. ábra. Az internet használók korosztályuk arányában és iskolai végzettség szerint 2002 és 2006 között (Sinka 2005, 2006)

A grafikon analízise alapján a következő megállapításokat tehetjük: (1) Az általános iskolai korosztály 2006-os 23\%-os korosztályon belüli web használata alig marad el az aktív 
korúak 2002-es 30\% körüli értékétől. (2) Az aktív korosztály négy év alatt megduplázta a web használók táborát (73\%), ami egyértelmüen az ezredfordulót követő, és a vállalati szféra mellett megjelenő, egyre olcsóbbá váló előfizetések eredménye is. Mindezt az aktuális MITS politikai programja is jelentősen támogatta. (3) Mindkét grafikoncsoport határozott növekedést mutat, és évről-évre megközelítőleg azonos trend mentén emelkedtek, és pozitívumként értékelhetően főként a munkképes aktív korcsoportok használata erősödött. (4) Négy év alatt a duplájára emelkedett a középiskolai korcsoport használata is (8-ról 17\%-ra). Ami viszont negatívumként írható a számlára, az elsősorban a szakiskolai tanulók felhasználásának igen alacsony szintje. A kutatási jelentések elemzéseiből kiderül, hogy ennek elsősorban két oka van: az érdektelenség, és a szakmák alacsony informatizáltsági foka. Nincs azonban összefüggésben a számítástechnikai eszközök és az internet elöfizetések árával. (5) A szakiskolák mellett, paralel kellene megjeleníteni a gimnáziumokat, mégis azokat magasabb értékekhez rendeltem. Ennek az az oka, hogy a WIP kutatási jelentései és az ITTK szociológusainak interjúiból tisztán kiderül, hogy a gimnáziumok tanulói, vélhetően a felsőoktatási követelmények és az egyébként is magasabb szociális háttér miatt, nyitottabbak a felhasználásra. Ebben saját kutatásaim is megerősítettek, amikor az e-learning használattal kapcsolatban interjúkat készítettem a Moodle-t használó középiskolai tanárokkal. Az ő lelkesedésüket egyedül az iskolavezetés negatív hozzáállása volt képes letörni. (6) A felsőoktatásban tanulók zöme (60\%) használ internetet, illetve azok, akik értelmiségiként munkájukhoz is szükségét érzik az infokommunikációs eszközök alkalmazásának, vagy a munkakörük olyan, azoknál ez meghadhatja a 73\%-ot. (7) Az idősornak köszönhetően nem csak emelkedő tendenciákról árulkodik a grafikon, de egyre ellaposodó korosztályos vonala $a$ használat évröl-évre későbbre tolódását is kirajzolja: a 30-50 évesek közötti átlag 40-50\%-os felhasználás egyszerre köszönhető a gazdaság informatizálódásának és az attitűdváltásnak is.

A görbe további laposodása várható a jelentések szerint, bár ezzel teljesen ellentmond a politika teljes kivonulása az információs társadalomfejlesztés területéről. Az aktuális válság miatt a visszatérés nem is várható túl gyorsan, aminek eredményeképpen kizárólag a megkezdett lendület, valamint a gazdasági-igazgatási kényszer, az oktatási rendszerek, és a belső igény tarthatja életben a növekedést.

Az információs társadalom dualista (hibrid) tere tehát egyre több embernek válik természetes közegévé, ráadásul mindebben az oktatási rendszerek játszák a főszerepet. Nem véletlenül éppen a Közháló Program 2004-es indulása adott lendületet kezdetben egy technokrata programvezérlésnek, majd fokozatosan a humán erőforrás oldal is, legalábbis stratégiák szintjén, dedikált teret kapott. ${ }^{284}$ Szükség is lenne rá, hiszen az információs társadalom hibrid terében a fizikai, mentális interfész-nélküliség mellett további „láthatatlan 
falak” is húzódnak, amelyek nem egy egyszerü digitális szakadékról árulkodnak, annál mélyebb társadalmi problémát is visszatükrönek:

„Az internetezők és a nem internetezők között egy néhol vékonyabb, néhol vastagabb láthatatlan fal húzódik, melynek az egyik oldalán nagyobb valószínűséggel találkozunk autonóm, pro-kapitalista, a magánbűnök megítélésében poszt-konvencionalista, evilági, azonosulási köreit tágra vonó, toleráns és jóhiszemű emberekkel, mint a másik oldalán, ahol többen vannak olyanok, akik az egyenlősítő államban hisznek, azonosulási körük szükebb, intoleránsabbak, és a tekintélyekben jobban megbíznak, míg egymásban kevésbé.” (Csepeli és Prazsák 2010, p. 178.) ${ }^{285}$

Az oktatási intézmények kulcsszerepét Csepeli és Prazsák könyvében közölt statisztika is megerősíti, kapcsolódva Z. Karvalics által idézett, Castells-től átvett gondolatához, amely szerint az információs társadalom kihívásainak a nyertesei kizárólag azok, akik a legtöbbet invesztálják az oktatásba és a kutatásokba, ami modern intézményi rendszert, korszerü felépítményeket és recens módszertant igényel. A hálózati társadalom konnekcionista oktatási paradigmája így nem csak egy újabb pedagógiai irányzat, hanem szerves része annak a társadalom-evolúciós folyamatnak, melyet a bevezetőben vázoltam. ${ }^{286}$

A konnetivizmus paradigmája a kibernetika paradigmájának egy igen fontos részparadigmája lesz, melynek belső szerkezeti meghatározottságát, horizontális és vertikális architektúráját, logikai müködési modelljét, fizikai és virtuális térbeli megjelenését is a társadalom aktuális paradigmája vezérli. Ha szeretnénk megragadni ennek geográfiai aspektusait, akkor az eddig megszokott kutatási irányok, iskolák határait fel kell lazítanunk. A hagyományosnak tekinthető megközelítéseket érdemes kiegészíteni:

Konnektivista geográfia kutatási rétegei és azok fontosabb tartalmi váza
Néhány klasszikus, illeszthető geográfiai terület

\section{Technológiai réteg}

infokommunikációs hálózatok kvantitatív és kvalitatív elemzése

hálózati kutatások, a hálózatok fizikai és logikai rendje, elméletek ${ }^{287}$

kooperatív terek, kollaborációs terek eszközrendszere (R/VR technológiák)

\section{Tanulási paradigma réteg}

konnektivista paradigma, oktatáspolitika, oktatásrendszer fejlődése, oktatási hálózatok, hálózati rétegek története, fejlődése

internet-kultúra földrajza (kultúrantropológia)
Gazdaságföldrajz

Infrastruktúra földrajza

Kommunikáció földrajz

Kulturális földrajz

Szociálgeográfia

Időföldrajz 
paradigma kutatás (konnektivizmus, kibernetika, kognitív tudományok)

a konnektivista nézőpontok: insider, outsider, narratív diszkurzivitások

e-learning terek, oktatási tér

\section{Konnektivista miliő rétege}

konnektivista földrajz tipológiája, a fizikai és virtuális hálózat modellezése

a konnektivista tér társadalom-morfológiája (cyber social network mapping) $)^{288}$

a konnektivista miliő (valós és kibertér alakzatok)

kooperatív terek, kollaborációs terek (R/VR osztályterem, könyvtár)
Természetiföldrajz

Gazdaságföldrajz

Társadalomföldrajz

Behaviorista földrajz

Időföldrajz

Kommunikáció földrajz

6. táblázat. A hagyományos geográfiai kutatási területek konnektivista megfeleltetése

A fenti táblázat a hagyományosnak nevezhető földrajzi irányzatokat próbálja megfeleltetni a konnektivista értelmezés szerint. Az összeállítás ugyan nem teljes, de érzékeltetni próbálja az attitűdváltás szükségességét, amelyet a kibernetika paradigmája kényszerít ki a szemlélődő laikusból (insider) és a vizsgálódó szakemberből (outsider) egyaránt. Visszatérve a humán interfész hiányára (HIG) az alábbi ábra mutatja szemléletesen azt a hiányzó területet, amelyet a fogalommal kapcsolatban statisztikailag megjeleníteni lehet. A humán interfész hiányának egyik lehetséges ábrázolásmódját az internethasználók iskolai végzettség és korcsoport szerinti összehasonlítása adja. (15. ábra) A korábban elemzésre kerülő grafikon két logaritmikus trendvonalának megrajzolásával kirajzolódik az a terület, amely a HIG értékének értelmezési területe.

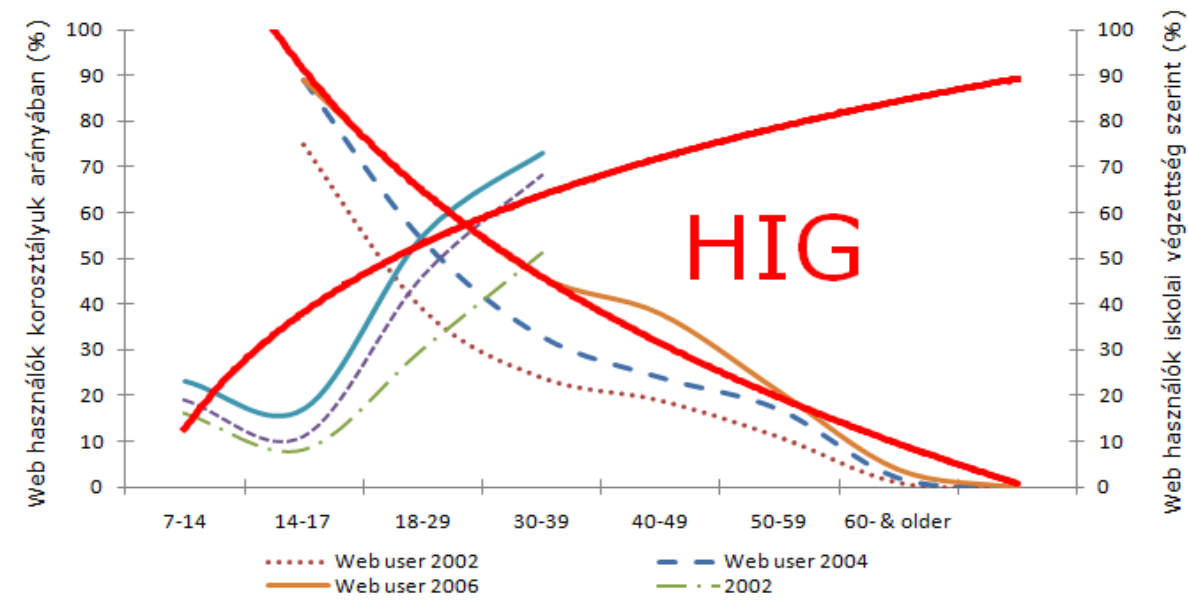

15. ábra. A humán interfész rés (HIG) és az internet használat összefüggése. (Sinka 2005, 2006) 
Minél kisebb a közrefogott terület, annál kisebb ez a rés, annál több az információs társadalom hibrid tereinek felhasználója, annál magasabb az infokommunikációs technológiák oktatásban használt aránya, annál egyértelmübb a szakképzés és a munka világában az információ technológiák folyamatmenedzsmentben betöltött szerepe, és végeredményben a kibernetika, a vezérlés tudománya ekkor érheti el a legnagyobb befolyását a társadalmi folymatokba is. Benigerrel egyetértve (2004, p. 685.):

„[...] az irányítás forradalma: azoknak a gyors változásoknak az összessége, amelyek a müszaki és gazdasági életben az információ gyüjtésével, raktározásával, feldolgozásával és közvetítésével foglalkozó szektorokban zajlanak le, és amelyeken keresztül elöírás jellegü vagy programszerü döntések befolyásolhatják a társadalom irányítását. Az irányítás forradalma a XIX. század második felére tehető kezdeteitől rendületlenül folytatódik mind a mai napig, és az utóbbi időben - a mikroprocesszoros technológia fejlődésével - ténylegesen fel is gyorsult. A XX. század történetében az irányítás forradalma - nagyságrendjét és a társadalomra gyakorolt hatásának mindent átható természetét tekintve, intellektuális és kulturális értelemben nem kevésbé, mint anyagi vonatkozásban - ugyanolyan fontosnak látszik, mint amilyen az ipari forradalom volt az előző évszázadban.” (Beniger 2004, p. 685.)

\section{Tudástársadalom és konnektivizmus - új Alexandria}

Ahogy Európa gazdasági-kereskedelmi és kommunikációs kapuja Amszterdam ${ }^{289}$, és ahogy az egykori Új Amszterdam New York lett ${ }^{290}$, úgy válnak vélhetően az oktatási intézmények a tudástársadalom közontjaivá. Míg azonban az oktatási rendszer belső architechtúrája változhat, a vertikális és horizontális térbeli hálózata hosszú ideig, akár évszázadokig létező, élő konnekciókon alapul. Történelmi akadályokat lehet rövidebbhosszabb ideig elébe gördíteni, de idővel ezek a csomópontok újraélednek és valódi magjuk, a tudást hordozó, őrző, és a közösség számára elosztó egységei körül újraszerveződnek. Ezek a magok, a csomópontok a könyvtárak, a társadalmak homeosztázisát biztosító tudás felkent szolgái és hordozói. ${ }^{291}$ Vitathatatlan az innovációs központok gazdasági szerepe, vonzáskörzetük régiókon, országhatárokon átnyúló hatása, a tudás allokációban betöltött szerepe azonban térben és időben sokkal koncentráltabb, mint a tudásközpontoké. ${ }^{292}$ Ezek a csomópontok zsugorítják össze a világot. (Barabási 2003, p. 90.) A tudástársadalom fogalma valójában akkor bekerült a köztudatba, amikor még az információs társadalom fogalomrendszere sem volt kidolgozott. A MITS 2003-as elfogadásának időszaka ez. ${ }^{293} \mathrm{Az}$ internet megjelenése, a személyi számítógépek elöretörése hamar nyilvánvalóvá tette a modern technológia forradalmát, és sejteni lehetett, hogy az ipari forradalmak által kiváltott változásokhoz hasonlóan a mostani is hasonlóan átütő erejü lesz. A tudástársadalom kialakításában, formálásában a tudás-centrikus világkép válik a vezérlő fonallá, amely mentén 
a tudástársadalom ideája megvalósulhat. A szükséges tér mérete, a társadalom úm. térszükséglete pedig planetáris méreteket ölt. Geográfiai szempontból a skálák igen változatosak lesznek. Az abszolút fizikai tér geometriája is csak közvetlen mérésekkel tudja tartani magát, mert a technológiai fejlődésnek köszönhetően a távolságok lerövidülnek, a manipulatív terünk már a közlekedési eszközök fejlödésével szélesebbre tárult. ${ }^{294}$ (Adams 1995, p. 273., Kellerman 2009b, pp. 50-52.)

Persze nehéz lenne segítség nélkül a globális méreteket átfogóan megragadni. Olyan alapegységeket kell keresni, amely általánosságban megragadhatóvá teszi a folyamatot. Olyat, amely nem az új technológia dinamikájából született, inkább éppen annak hatására dinamizálódik, változik, megőrzi régi funkcióit, miközben a változás minden lehetséges jegyét magán hordozza. Ezek lehetnek a könyvtárak. Egyetértek Tóth Mátéval, aki „az információs társadalom alapintézménye”-ként aposztrofálja a könyvtárakat (Tóth M. 2009). ${ }^{295}$ Intézményük és intézmény-rendszerük/hálózatuk, történelmileg a tudásanyag koncentrációjában vállalt szerepük révén mindig is csomópontok, hálózati központok voltak. A könyvtárak hagyományos feladatai (a gyüjtés - leírás - rendszerezés - feldolgozás megőrzés) voltaképp a mai napig, az alexandriai könyvtár óta nem változott. Ami a változást leginkább transzparensé és kutathatóvá teszi, az nem más mint az információkezelési technikák (technológia és metódus) rendkívül gyors megjelenése és elterjedése a könyvtárakban. ${ }^{296}$

A könyvtárak azért jelentenek izgalmas megközelítést a konnektivizmus földrajzában, mert térben megfogható, strukturálisan kirajzolódó rendszerben működnek. A könyvtárak hálózata és a vele paralel iskolarendszer egy természetes konnektivista mutualizmus. A modern könyvtár, a hagyományosan meglévő fizikai hálózatát virtuális rétegek sokaságával egészítette ki: e-szolgáltatások (kölcsönzés, katalógusok), jogtisztán hozzáférhető és nagy sebességgel kereshető e-könyvek, de ide tartoznak a legújabb trendek is, mint az e-learning és az e-portfólió. ${ }^{297}$ A tudás egyirányú kiáramoltatása lényegében megszünt, helyét a kétirányú kommunikáció vette át, egyre nagyobb helyet (elsősorban virtuális teret) biztosítva a nonformális tudásátadásnak. Ez a „nyitottság” egyes esetekben természetes folyamat és attitűd, más esetekben a kényszer szülte realitás. ${ }^{298}$ A könyvtárak ilyen intenzív elöretörése leginkább ott mutatkozik meg, ahol teret kapnak a tudás átadásban, a képzésben. A szakma maga is megdöbbenéssel veszi tudomásul, hogy új munkakörök születnek, erősödik a könyvtárpedagógia, a könyvtár-mentor (az egykor IT mentor program új, támogatás nélküli, önként felvállalt programja), megjelenik a tudományos kutató, az adatbáziskezelő és persze tovább bővül a közszolgálati feldatkör.

Amikor George Siemens ${ }^{299}$ 2005-ben publikálja az Egy tanuláselmélet a digitális korszak számára c. cikkét, illetve 2006-ban a Knowing knowledge c. könyvét, Manuel 
Castells $^{300}$ már majd egy évtizede megjelentette az Információ korát és Siemens ekkor márvalószínüleg Barabási Albert-László ${ }^{301}$ Behálózva c. könyvét is olvasta ${ }^{302}$. Siemens egyik korábbi cikkének összefoglalójában pedig ezt írja a konnektivizmusról:

„A konnektivizmus olyan tanulási modellt mutat be, amely elismeri a társadalom szerkezeti eltolódásait, ahol a tanulás már nem egy belső egyéni tevékenység. Új eszközök használatával megváltozik az emberek munkája és müködése. Az oktatás csak lassan ismerte fel az újszerü tanulási eszközök valamint a környezeti változások tanulásra gyakorolt hatását. A konnektivizmus bepillantást enged azon tanulási készségekbe és feladatokba, melyek egy digitális korban a tanulók látványos fejlődéséhez szükségesek.” (Siemens 2004) - fordítás tőlem. ${ }^{303}$

Ebben a virágzó digitális érában a tanulás ismét felértékelődik, csak épp a helye, az eszközrendszere és didaktikai környezete változik meg, méghozzá radikálisan. ${ }^{304} \mathrm{~A}$ tanulás, a digitális kor, a hálózatok elválaszthatatlanok egymástól, s ehhez a klasszikus kulturális földrajz szempontrendszerét, ahogy arról a fejezetben is szó esett, érdemes újragondolni. A tanulási terek, a tudásátadás közvetlen szegmensei épp úgy dualista térkonstrukciókká válnak, mint ahogy azt a valós és virtuális tereknél láthattuk. Amennyiben azonban tovább bontanánk a virtuális tanulási tereket, ahogy Kellerman tette a kiberték osztályainál, hamar szembesülnénk azzal, hogy a tanulási terek kibernetikai alakzatai nem csak a földrajzi metafórák szerint megjelenített kibertér, hanem az auditív és vituális terek mellett uralják a tipográfiai tereket is. (McLuhan 2001, p. 50-64.) Ezek a terek nem egyszerüen HTML kódok, hanem textusok, intratextusok, intertextusok, és természetesen hipertextusok. ${ }^{305}$ A tipográfiai tér, „tipográfiai embert” is követel. (McLuhan 2001, p. 268-271.) Aki nem lesz képes ebben a környezetben feltalálnia magát az menthetetlenül elveszik, „mert a vizuális érzék elkülönítése, továbbá az érzékek közötti kölcsönhatások és a lét hálóján áthatoló fény érzékelése oda vezetett, hogy „az emberi gondolkodás többé nem érzi magát a dolgok részének”.” (McLuhan 2001, p. 269.) 


\section{ÖSSZEGZÉS}

A dolgozat elméleti értekezés az információs technológia földrajzi gondolkodásra gyakorolt hatásáról, annak az ezredfordulót követően egyre intenzívebben kibontakozó jelenségéről. A forrásmunkák áttekintése, elemzése és a kortárs geográfiai irodalom ide vonatkozó részének egységes kánonkénti értelmezése elméleti keretet biztosíthat a további geográfiai aspektusú vizsgálatokhoz. A társadalmi-gazdasági jelenségeket mindig összefüggéseiben és a térbeli dinamizmusuk szerint vizsgáló geográfusok modern kori célterületévé válhat ez a téma. A megtalálható források összevetése, olvasatai egy nemzetközi geográfiai iskola felé nyithatnak kaput a honi geográfia képviselőinek, amint arra példát is hoz a fentebb már említett módon a dolgozat. Ennek jelentősége az, hogy a hazai kutatások még összevethetöbbek lehetnek a nemzetközi írásokkal, nem csupán statisztikailag, de gondolatilag is elősegítve a hazai és a nemzetközi szakmai diskurzus kiszélesítését.

$\mathrm{Az}$ információs társadalom kutatások hazai és a nemzetközi szakirodalomban alkalmazott vizsgálati módszerei, kevés kivételtől eltekintve, nehezen vethetők össze. Észrevehető azonban a konvergencia néhány cikkben (Kanalas és Nagy 2009, Sinka 2007, 2009). A kutatás során sikerült a magyarországi kutatók munkáit nemzetközi közösség elé vinni. A NETCOM 2009-ben megjelent különszámának elkészítésében vendégszerkesztőként működhettem közre (NETCOM, Vol. 23., 2009, No 1-2.). A tematikus szám a magyarországi információs társadalom kutatóknak, és persze a magyar információs társadalomnak adott lehetőséget a nemzetközi bemutatkozásra egy tanulmánykötet keretében.

Az első tézis azt fogalmazta meg, hogy a modern infokommunikációs technológia hatással van a földrajzi gondolkodásra. A 20. század végére, a posztindusztriális társadalmi formát meghaladó társadalmi alakulat egy olyan információ-dominanciára épülő társadalom, melynek társadalmi-gazdasági terét átszövö új paradigma a kibernetika lesz.

Az új jelenség az ezredfordulót követő évtizedben bukkant fel, elsősorban a távközlő hálózatokon terjedő internet szolgáltatások elterjedésének és a számítógépek penetrációs szint növekedésének eredményeként. Geográfiai szempontból a jelentősége abban mérhető, hogy a nemzetközi vizsgálatokkal összhangban, a hazai publikációkban is egyre inkább felfedezhető ennek a jelenségnek (kezdetben döntően infrastrukturális aspektusú) vizsgálata. Ezek az elméleti és empirikus vizsgálatok az infokommunikációs technológiát, mint a térbeli alakzatok új szervezőjét jelenítik meg. A dolgozat eredménye, hogy egyrészt azonosította ezeket a kutatási kereteket, másrészről kijelölte a továbblépés paradigmatikus irányait. 
A második tézis szerint az információs társadalom tere minden esetben a valós tér elemeire épül, attól elválaszthatatlan, azzal azonos vagy ahhoz hasonló metaforikus fogalomés szimbólumrendszerrel leírható. Ez a tér egyszerre van jelen a fizikai és a virtuális közegben, és speciális hibrid térkonstrukciót alkot.

A dolgozatban sikerült meghatározni az információs társadalom elméleti és fizikai környezetének (miliőjének) határait. Az információs társadalom földrajzi tere az ember valós és virtuális térmanipulációs képességének határáig terjed. Ez a térkonstrukció az információs társadalom kvázi-plasztikus tere, amely középpontjában minden esetben az ember áll, és a tér morfológiája, léptéke az emberi aktivitás (manipulációs képesség) intenzitásától függ. Az egyes eszközök technológiai fejlettségétől, a használat időtartamától függően az emberi aktivitás terét kirajzoló manipulációs tér alakja folyton változó, plasztikus alakzat lesz.

Az elemzés igazolta, hogy a morfológia plasztikusságát számos (gazdasági, társadalmi, technológiai, humán) tényező gátolhatja vagy elősegítheti, ezért az információs társadalom hibrid terét egy kvázi-plasztikus (a földrajzi tér egy adott pontján adott időpillanatban rendelkezésre álló feltételek szerinti) topológia jellemezheti a legpontosabban. Az infokommunikációs technológia által generált virtuális terek és kapcsolatok ugyanis nem biztosítanak rögzíthető lokalitást, ezért míg a fizikai aktivitás csak a fizikai közelség esetében valósul meg, addig a virtuális térben az infokommunikációs technológia által engedélyezett lokációk, többszörös dimenzionalitást és egyidejüleg megsokszorozható identitást biztosítanak. Miközben a dualista (hibrid) térkonstrukció mindegyikében végezhetünk aktivitást, a paradigma miliője mégsem tisztán egymást követő folyamatok által szervezett térkonstrukcióból fog állni, amelyet a tér-idő egymásutánisága határoz meg, hanem egy olyan vezérlés orientált logika építi fel, amely a hálózatszerveződés (és a kibernetika) logikájára épül, ez lesz a PDP. A párhuzamosan megosztott információ feldolgozó metódus (Parallel Distributed Processing) hasonlít az agymüködés és a legfejlettebb mesterséges intelligencia (MI) megoldásokra épülő komputációs technológiák környezetészlelési technikáira. A metódus elsajátításának hiánya esetében az információs társadalom tere mind vizuális, mind aktivitási térként láthatatlan térforma marad.

A harmadik tézis azt emeli ki, hogy a földrajzi információk összegyüjtése, megértése és elsajátítása egyre inkább attól függ, hogy az egyén milyen alapvetö információkezelési technikákat ismer.

Igazolódott az, hogy a technikai kompetencia (a fizikai eszközkészlet aspektusában) elvben mindenkinek adott, megléte azonban jelentősen függ a társadalmi státusztól. Az empirikus kutatások arra az eredményre jutottak, hogy az IKT eszközök beszerzése nem jövedelem, iskolázottság, hanem érdeklődés és felhasználói kompetencia kérdése. Nem a 
technológia a kizárólagos oka annak, hogy egyesek érzékelik, mások nem az információs társadalmat. Az információs társadalom szerkezete, mozgási dinamikája és a felhasználók dimenziója markáns különbségeket hordoz magában a fizikai térhez képest. Ezt egyetlen lépésből a kognitív evolúció nem képes áthidalni, idő kell neki. Az időt pedig a kompetencia fejlesztése, vagyis a tanulás és nem valamiféle természetes vagy mesterséges maturáció jelenti, ezért van jelentősége a tudás kompetenciájának. A kutatás a földrajzi észlelés kognitív folyamata, az információs társadalom térbeli szerkezete, alakzatai, a térkonstrukciókban végezhető manipuláció és az általa generált társadalmi-gazdasági aktivitási tér között vont párhuzamot, és a dinamikáért az információkezelés technikáinak meglétét vagy hiányát tette felelőssé.

A negyedik tézis azt hangsúlyozza, hogy az információkezelési technikák csak közvetve függnek a technológiai fejlettségtöl. Az eszközök önmagukban nem javitanak az egyén térbeli megismerési technikáin, de a tanulási folyamatok során a (valós és virtuális) földrajzi környezetböl származó információk befogadását elösegitö kompetenciákat alakítanak ki. Ez egy asszimilációs folyamat, amely során egyénileg különböző kompetencia-készletek jönnek létre, attól függően, hogy az entitás milyen kompetenciák adaptálására képes. A végeredmény egy a földrajzi környezetröl aggregált tudás lesz.

A kutatás eredményeként igazolást nyert, hogy az információkezelési technika nem függ alapvetően a technológiai fejlettségtől, mert valójában minden társadalmi kornak, az adott társadalmi homeosztázis (nevezhetjük belső egyensúlynak) fenntartása érdekében működtetett információátadási technikája megköveteli a szükséges kompetenciákat. Ezek a kompetenciák a társadalom információtechnológiára épülő „architektúrájában” olyan tapasztalati kompetenciákat igényelnek, amelyek már a mentális kognitív folyamatokban is zavart képesek okozni. A kognitív disszonancia oka pedig elsősorban a duális térkonstrukció, a valós és virtuális terek közötti váltás miatti probléma, a túldimenzionálás, az adaptációs képesség elvesztése, melyek visszavezethetőek a virtuális tapasztalati tér hiányára, valamint a virtuális tér azon tulajdonságára, amely lehetővé teszi a multi-dimenzionalitást, vagyis az identitások és lokalitások sokszorozását. Az entitás ekkor, a földrajzi térről rendelkezésére álló hiányos ismeretei miatt, túldimenzionálja magát, vagyis megsokszorozza saját entitását. A túldimenzionálás lényegében „túlvállalása” lesz annak a térnek, amelyet az adott entitás képes bejárni, a róla begyüjthető földrajzi információkat befogadni és adaptálni.

A technológia és társadalom interdependenciájának erősödésével pedig az abszolút fizikai tér tapasztalati reprezentációi egyre erősebben jelennek meg, tovább erősítve a térbeli, identitásbeli és aktivitásbeli függőséget. A folyamat egyre hangsúlyozottabban jelenik meg napjainkban, és hatását számos területen, mint például a munka, az online játékok vagy a 
virtuális világok vizsgálatánál is kimutatták. A virtuális terek használatának bővülése egyértelmủen a modern technika napi használata által elsajátított kompetenciák eredménye, amely egy hibrid földrajzi környezetről alkotott térhasználat és a róla szerzett ismeretek együttesének köszönhetö.

A tézisek összefoglalásaként, illetve az elsö tézisben kiemelt célkitüzés alapján kijelenthetö, hogy a kutatás sikeresen definiálta és leírta a földrajzi gondolkodás új paradigma keretének értelmezési határait: a társadalmi miliöt, a szerepköröket, a funkcionalitást és magát a meghatározó paradigmát.

A kutatási eredményt összefoglaló ábra egy tér - idő - paradigma skála mentén kirajzolódó, a megelőző tudományos diskurzusokhoz kapcsolódó új paradigmát, az „információkezelés forradalmát” mutatja be. A geográfiai szemlélet fejlődéstörténetének elmúlt ötven évében lassan egymásra találhatnak a laikusok és a szakemberek. A közföldrajz újjáéledését is kikényszerítő mechanizmus már a behavioristáknál elindult, az információáramlás gyorsulásával pedig hálózatba szerveződött. A kutatás által vizsgált összefüggések közé sorolható a geográfiában az antropocentrikus perspektívák újraéledése, s ennek csak egy szegmense a közföldrajzi elemek sokasodása (médiában, publikációkban, webes alkalmazásokban), amelyekhez egyre határozottabb leíró, a témát okozati összefüggéseiben is kifejtő közlési mód (narratív diszkurzivitás) is társul. A kibernetika által biztosított valós és virtuális miliő pedig speciális szerepköröket, illetve szereppárokat (ergon \& poesis, logos \& paidea) követel meg. A hazai és nemzetközi tipológiát alapul véve az egyes szerepeket a dolgozat részletesen tárgyalta. Az ergon és a poesis a gyakorlati alkalmazást, míg a logos és a paidea inkább az elbeszélő (narratív), formai jegyeket hangsúlyozó irányzatot képviseli a geográfus szakma számára.

A dolgozatban megfogalmazott tézisek erre az új kibontakozó jelenségre, mint problémakörre irányult. Az információs társadalom a társadalmi-evolúció fejlődési szakaszának jelenleg meghatározó, de egyáltalán nem végleges stádiuma. Az információs kor társadalmi formátumának a szerepe, jelentősége abban mutatkozik meg, hogy kijelöli a posztindusztriális társadalmak gondolati fejlődésének mintázatát, meghatározva azok technológiai aspektusú interdependenciáját. Ebből születik az a fajta technológiai-társadalmi mutualizmus, vagyis a társadalom és a technológia számára egyaránt elönyös egymásrautaltság, amely rámutat az infokommunikációs technológia és az emberi gondolkodás genetikai párhuzamaira, a kognitív észlelés és a hálózatok szerveződésének logikájára, melyben módszertanként ölt testet a konnektivizmus oktatási paradigmája.

$\mathrm{Az}$ információkezelés forradalmát kijelölő és biztosító keretet, az információs társadalom terének miliője, a tudás és cselekvés párokra épülő szerepkör, valamint a 
kibernetika paradigmája adja, a laikus (insider) és a szakmaiságot képviselő (outsider) nézőpontok mentén, ahogy azt az alábbi ábra is szemlélteti.

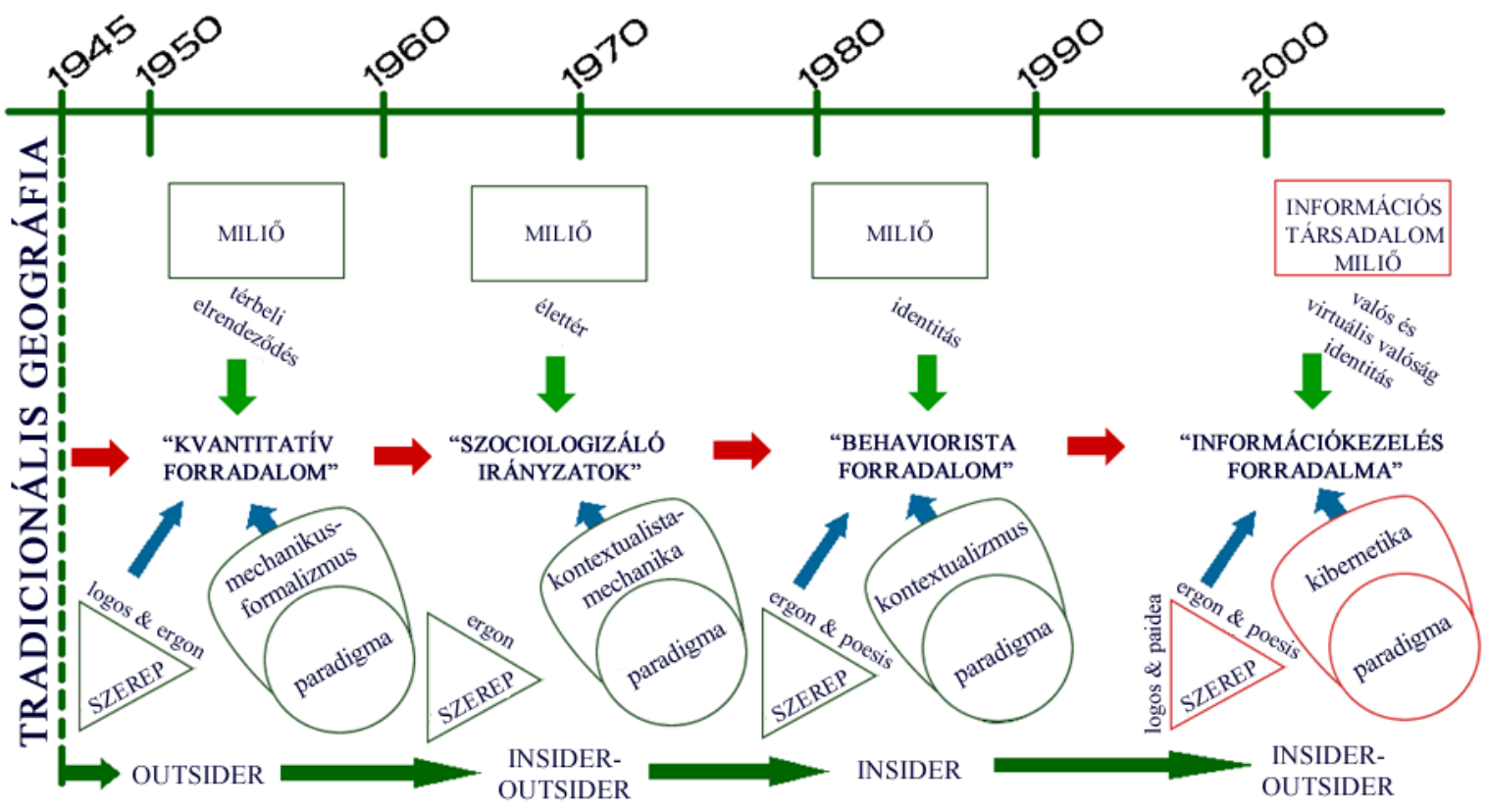

16. ábra. Forradalomról forradalomra, a földrajzi gondolkodás paradigmái 1945-töl napjainkig.

(Cséfalvay 1990, Sinka 2008, 2009 - aktualizálva a szerzö által)

A földrajz több mint 2000 éves tudomány. Kutatási területei és módszerei a kezdetektől fogva szorosan kötődnek az adott társadalmak fejlettségi szintjéhez. Az elmúlt néhány évben az IKT tudásalapú társadalom építésére gyakorolt hatása, különösen az IKT földrajzi aspektusa a tudományos kutatás egyik fő célpontjává vált. A technológiai fejlődés hatásai, az IKT technikák alkalmazásának előnyei kihatnak földrajzi ismereteinkre és gondolkodásunkra egyaránt.

A dolgozat terjedelme nem adhatott lehetőséget arra, hogy részletesen kifejtse az egyes IKT eszközök által a földrajzi gondolkodásra gyakorolt változásokat. Inkább azokra a kérdésekre kereste a választ, hogy felvázolható-e összefüggés az emberi tér észlelésének, a tér megismerésének a folyamata, és az alapvető információátadási technikák/sémák között? Vane szerepe az emberi társadalmak fejlődésének abban, ahogy ma látjuk a világot? Léteznek-e olyan mérföldkövek, amelyekhez a földrajzi gondolkodás fejlödési szakaszait köthetjük? Történik-e paradigmaváltás a földrajzi gondolkodásban vagy csupán egy régi paradigma újjászületésének vagyunk tanúi?

A történeti áttekintés segíthet megérteni azt az utat, amelyet a tradicionális földrajzi felfogástól napjainkig a földrajzi gondolkodás bejárt. A „forradalomról forradalomra” kiteljesedő változások a hagyományos földrajzi környezetben még viszonylag könnyen elhelyezhetőek voltak. Az infokommunikációs technológiák által előidézett változások 
azonban új, eddig ismeretlen térkategóriákat hoztak létre, melyekhez a megfelelő térfogalmakat is meg kell alkotnia a kutatóknak. ${ }^{\mathrm{i}}$ Ahogy Bakis (2001) fogalmaz: „A földrajz tudománya messze áll még a kifulladástól, és nem pusztán fizikai jelenségekkel foglalkozik: hanem elkezdte felfedezni a 21. század földrajzi terét: mint például a 'geokiberteret'.”ii

A hagyományos értelemben vett környezetünket egy, a modern technológiák alkotta kiberteret is magában foglaló új térbeli forma, az információs társadalom tere (ITT) veszi át.iii Az ITT-ben létrejövő mesterséges térformák, térkreációk és a bennük létrejövő társadalmi csoportok minden esetben valós térbeli alapokon épülnek fel (Bakis és Roche 1997). Leírásukhoz a fizikai földrajzban is használatos földrajzi metaforákat és térkategóriákat alkalmazunk (Mészáros 2000). A modern eszközök által teremtett virtuális világban a meg szokott földrajzi fogalmaink segítenek tájékozódni, miközben észrevétlenül új, virtuális identitásunkat is ki kell alakítanunk. A korábbinál komplexebb térben azonban csak azok képesek a meglévő (fizikai) identitásukat a virtuális térben implementálni -lényegében létezni-, akik a társadalmi homeosztázis fenntartása érdekében létrehozott információs céleszközöket és eljárásokat ismerik és használják (Wiener 1974). Ehhez lényegében ismerniük kell a modern információkezelés technikáját.

Az információk, köztük a földrajzi információk is, döntő többsége ma már az IKT eszközökön keresztül jut el hozzánk, és nagyon gyakran megelőzik a fizikai észlelést. Bakis találóan mutat rá, hogy a különféle médiumok és telekommunikációs eszközök használatával egyre inkább az idő játssza a központi szerepet a társadalmi kapcsolatok ritmusában és a kapcsolatokban, és nem a távolság. (Bakis és Roche 1997)

\footnotetext{
${ }^{i}$ Bakis és Roche 1997, Bakis 1995a, 2001, Bakis és Dupuy 1995b, Mészáros 2000, Sinka 2004 és mások.

ii „The science of geography is far from exhausted and is not concerned only with physical phenomena: it has begun to explore to geographycal space of the XXIst Century: i.e. the 'geocyberspace' (Bakis 2001).”

iii Bakis 'geocyberspace' fogalmához hasonló, közel azonos megközelítésről van szó.
} 


\section{SUMMARY}

The dissertation is a theoretical paper about the effect of information technology on geographical thinking, about its more and more intensely unfolding phenomenon following the turn of the millennium. The review and analysis of source-books, and the uniform interpretation of the related pieces of contemporary literature on geography might provide a theoretical framework for further geographically oriented studies. Present subject might become one of the major modern era target areas of geographers studying social-economic phenomena always considering their interconnections and spatial dynamism. The comparison and readings of the discoverable sources might open up a door for the Hungarian representatives of geography towards an international geographic school, which is also exemplified in this dissertation in the way already outlined above. The significance of this is that Hungarian studies could be even more comparable to international papers, thus contributing to the extension of both Hungarian and international professional discourse not only statistically, but mentally as well.

The research methods applied in the Hungarian and in the international literature of researching the information society, apart from a few exceptions, are difficult to compare. In some papers, however, convergence can be traced (Kanalas and Nagy 2009, Sinka 2007, 2009). In the course of the research, we managed to present the work of the Hungarian researchers in front of an international community. I had a chance to contribute to the preparation of the special edition of NETCOM published in 2009 as a guest editor (NETCOM, Vol. 23, 2009, No 1-2.). The thematic edition provided an opportunity for the Hungarian researchers of the information society and naturally for the Hungarian information society to introduce themselves at international level in the form of a study volume.

The first thesis stated that modern infocommunication technology influences geographical thinking. By the end of the $20^{\text {th }}$ century, the social formation surpassing the postindustrial social form is a society based on information-dominance with cybernetics as the new paradigm interlacing its social-economic space.

The new phenomenon emerged in the decade after the turn of the millennium, primarily as a result of the spread of the internet services via telecommunication networks and of the increased penetration level of computers. From geographic aspect this is significant in as much as, in accordance with international studies, the study of the phenomenon (at the beginning dominantly from infrastructural aspect) more and more frequently appears in the Hungarian publications. These theoretical and empirical studies present infocommunication technology as a new organizer of spatial constructions. The achievement of the dissertation is 
that it has identified the framework of the research on the one hand, and has determined the paradigmatic directions to keep to on the other.

According to the second thesis, the information society space is always built on and is inseparable from the elements of the real space, and it is describable by a metaphorical system of concepts and symbols identical with or similar to it. This space is simultaneously present in the physical and virtual medium, it creates a special hybrid construction of space.

In the dissertation I managed to define the limits of the theoretical and physical environment (milieu) of the information society. The geographic space of the information society reaches as far as the limit of one's real and virtual space manipulating skills. This construction of space is the quasi-plastic space of the information society, which is in each case centred around man, and the morphology, scale of the space depend on the intensity of human activity (manipulation skills). Depending on the technological advancement and on the application period of certain devices, the shape of the manipulation space defining the human activity space is a constantly changing, plastic configuration.

The analysis confirmed that the plastic nature of morphology can be hindered or facilitated by a number of (economic, social, technological, human) factors, therefore the hybrid space of the information society can most precisely be characterized by a quasi-plastic topology (under conditions given at a certain place and at a certain point of time in the geographical space). Namely, virtual spaces and connections generated by the infocommunication technology do not provide fixable locality, therefore, while physical activity takes place only in the case of physical proximity, localities granted by the infocommunication technology in the virtual space provide multi-dimensionality and multipliable identity. While activity can be performed in each dualist (hybrid) construction of space, the milieu of the paradigm is still not composed of constructions of space organized by clearly sequential processes, which is determined by the consecutive nature of space-time, but it is organized along a control-oriented logic that is based on the logic of network organization (and cybernetics), this is PDP. The parallel distributed information processing method (Parallel Distributed Processing) is similar to the environment perception techniques of computational technologies based on cerebration and the most advanced artificial intelligence (AI) solutions. When the acquisition of the method fails, the space of the information society remains an invisible space form both as a visual and as an activity space.

The third thesis emphasises that the collection, understanding and acquisition of geographical information increasingly depend on what kind of basic information handling techniques one is familiar with.

It has been justified that technical competence is in principle available for everybody (from the aspect of the physical set of means), its existence, however, strongly depends on 
one's social status. Empirical research findings show that the acquisition of ICT devices is not a question of income or qualifications but of interest and user competence. The fact that some people can perceive the information society, while others cannot does not exclusively depend on technology. The organization, motion dynamics of the information society and the users dimension are radically different from the physical space. Cognitive evolution is incapable of overcoming this with one step taken, it needs plenty of time for that. Time is measured by competence improvement, namely learning and not by some natural or artificial maturation, this is what makes knowledge competence significant. Research is the cognitive process of geographical perception, it drew a parallel between the spatial structure, the figures of the information society, the manipulation that can be performed in the space constructions and the social-economic activity space generated by it, furthermore, for dynamics it put the blame on the existence or the lack of information handling techniques.

The fourth thesis emphasises that information handling techniques depend on technological development only indirectly. Devices in themselves do not improve the perception techniques of an individual, but, in the course of learning processes, they create competencies facilitating the receipt of information from the (real and virtual) geographical environment. This is an assimilation process, during which individually varied competencesets are created depending on that kind of competencies an entity is able to adapt. The final result is knowledge aggregated from the geographical environment.

Research findings have verified that information handling techniques do not essentially depend on technological advancement, because the information conveying technique of every social era operated in order to maintain the given social homeostasis (may call it internal balance), requires the necessary competencies. In the "architecture" of modern society based on information technology, these competencies require empirical competencies which can cause disorder even in the mental cognitive processes. The reason for cognitive dissonance is primarily the dual construction of space, the problem due to alternating between the real and virtual spaces, over-dimensioning, the loss of the adaptation ability, which can be traced back to the lack of a virtual empirical space, as well as to the characteristic feature of the virtual space that makes multi-dimensioning, i.e. the multiplication of identities and localities possible. An entity then, due to its imperfect information about the geographical space, overdimensions itself, namely it multiplies its own identity. Over-dimensioning is essentially "over-venturing" the space that the given entity is able to cover, the available pieces of geographical information about which it is able to receive and adapt.

As technological and social interdependency become stronger, the empirical representations of the absolute physical space appear stronger and stronger, enhancing dependence with respect to space, identity and activity. The process appears to be more and 
more emphatic today, its effects have been detected in several areas such as the study of work, online games or virtual worlds. The increasing use of virtual spaces is definitely the result of competencies acquired during the daily use of modern technology, which is due to the application of space formed copying a hybrid geographical environment and to the collection of information about it.

As a summary of the theses, and on the basis of the objective emphasised in the first thesis, it can be stated that the research successfully defined and described the interpretation framework of the new paradigm frame of geographical thinking: social milieu, cues, functionality and the determining paradigm itself.

The figure summing the research findings presents a new paradigm along a space - time - paradigm scale, related to the previous scientific discourse, i.e. "the revolution of information handling”. For the last fifty years of the history of development of geographic approach, laymen and professionals can gradually find one another. The mechanism triggering also the revival of public geography had already begun with the behaviourists, and it was organized into a network as the flow of information became faster.

The revival of anthropocentric perspectives can be categorized together with the relations studied by the research, and the multiplication of public geographical elements (in the media, publications, web applications) is only one segment of this, which are accompanied by a more and more definite means of communication (narrative discourse), treating also the causal relations of a theme. The real and virtual milieu provided by cybernetics requires special roles and role pairs (ergon \& poesis, logos \& paidea). Based on Hungarian and international typology, each role is discussed on the dissertation in detail. Ergon and poesis represent practical application, while logos and paidea represent a trend highlighting narrative, formal features for professional geographers.

Each thesis presented in the dissertation is centred round this new emergent phenomenon, as a set of problems. At present, the information society is a determining, but not at all final stage of the developmental phase of social evolution. The role and significance of the social format of the information era is indicated by designating the pattern of mental development of post-industrial societies, defining their interdependency from a technological aspect. From this the kind of technological-social mutuality, in other words interdependence beneficial for both society and technology, is born that emphasises the genetic parallels between infocommunication technologies and human thinking, the logic of cognitive perception and network organization, in which the educational paradigm of connectivity is embodied in the form of methodology.

The framework designating the information handling revolution is built up from the milieu of the information society space, from the functionality based on the knowledge and 
action pairs, as well as from a cybernetics paradigm, along the points of view of a layman (insider) and a person representing professionalism (outsider), as indicated in the figure below.

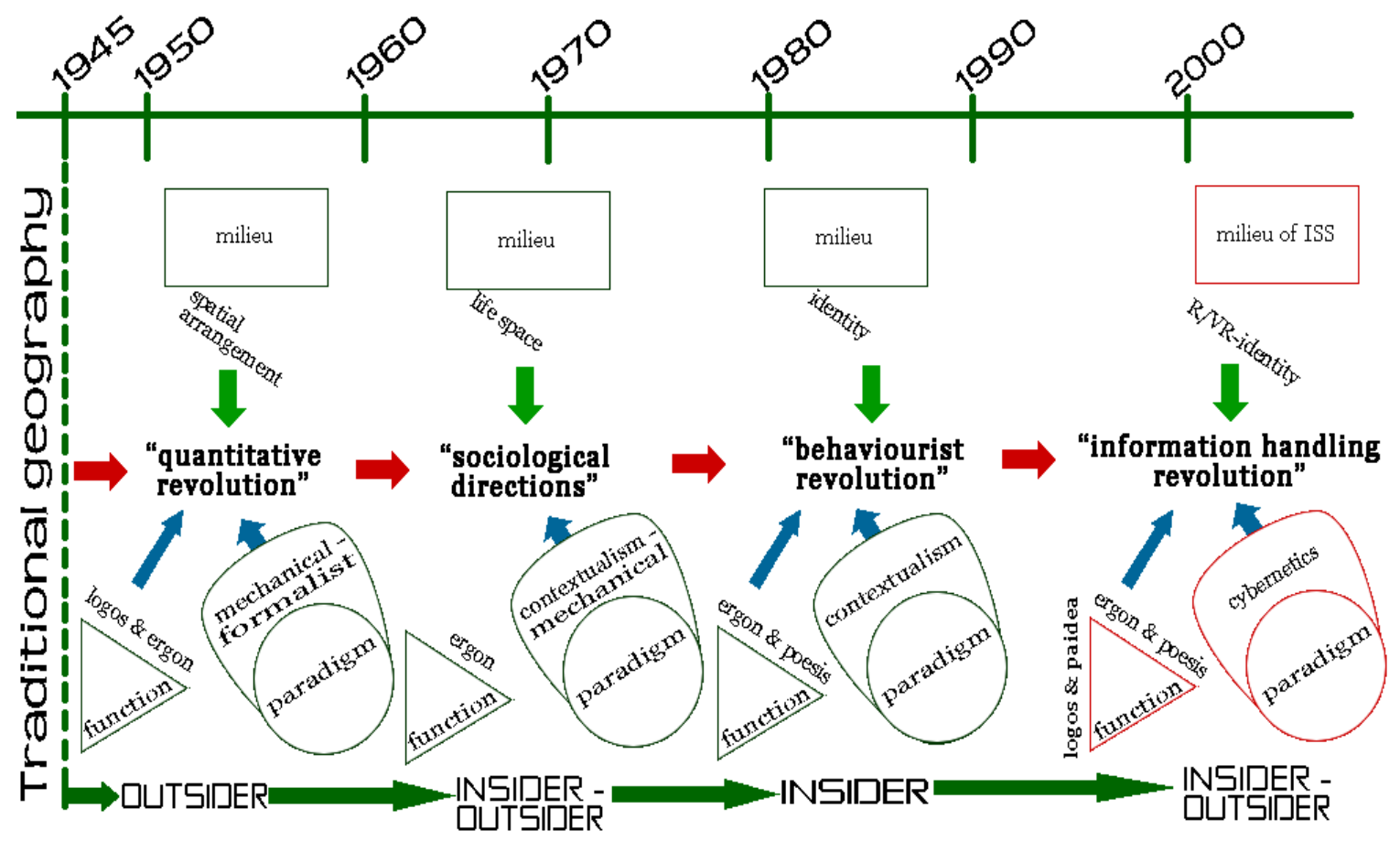

17. From revolution to revolution, the paradigms of geographical thinking from 1945 up to today (Cséfalvay 1990, Sinka 2008, 2009 - actualized by the author)

Geography was founded more than 2000 years ago. Undoubtedly, its research fields and methods have been closely connected to the development level of the given societies. In the last few years the effects of ICT in building knowledge based society, especially, the geographical aspect of ICT became one of the major focuses of the academic research. The effects of technological developments, the benefits of applying ICT techniques have influenced our geographical knowledge and thinking as well.

The length of the paper did not allow a detailed discussion of the influence of certain ICT devices on geographical thinking. It rather searched for an answer to the question whether the process of perceiving, experiencing human space is in any connection with the basic techniques/schemes of conveying information. Does the development of human societies affect the way we see the world today? Are there milestones that the developmental stages of geographical thinking can be connected to? Is there a change of paradigm in geographical thinking or are we merely witnessing the rebirth of an old paradigm?

The historical overview might help us understand the stages of the development of geographical thinking from the traditional geographical approach up to the present. The changes during the progress "from revolution to revolution" could relatively easily be placed 
in the traditional geographical setting. The changes brought about by infocommunication technologies, however, created new categories of space unknown so far, to which the researchers also had to form the appropriate concepts of space. ${ }^{\text {iv }}$ As Bakis (2001) phrases it: "The science of geography is far from being exhausted and is concerned not only with physical phenomena: it has begun to explore to the geographical space of the $21^{\text {st }}$ century, i.e. the 'geocyberspace'."

Our traditional environment is being taken over by a new spatial form, the Information Society Space (ISS), also including the cyberspace created by the modern technologies ${ }^{\mathrm{v}}$. The artificial space forms, space creations and the social groups emerging in the ISS are in each case built on real spatial bases (Bakis \& Roche, 1997). They are described with geographical metaphors and space categories also used in physical geography (Mészáros, 2000). Our common geographical concepts help us find our way in the virtual world of modern devices, meanwhile our new, virtual identity must also be created unnoticed. However, it is only those who know and apply the information devices and procedures created in order to maintain the social homeostasis that are capable of implementing their existing (physical) identity in the virtual space - i.e. capable of existing in a space more complex than the earlier one (Wiener, 1974). This basically requires the knowledge of the techniques of modern information handling.

Today, the vast majority of information, also including geographical information, is conveyed via ICT devices, and they very often precede physical perception. Bakis appropriately says that by using various media and telecommunication devices, the central role in establishing the rhythm and relations in society is growingly played by time rather than by distance. (Bakis and Roche, 1997)

\footnotetext{
iv Bakis and Roche 1997, Bakis 1995a, 2001, Bakis and Dupuy 1995b, Mészáros 2000, Sinka 2004 et al.

v An approach similar to, and almost identical with Bakis's concept of geocyberspace.
} 


\section{KÖSZÖNETNYILVÁNÍTÁS}

Szeretnék köszönetet mondani tanáraimnak és professzoraimnak, akik nem csak tanítottak, de neveltek és irányítottak is a tanulmányim során. Elsőként Csatári Bálintnak, tanáromnak, professzoromnak szeretném megköszönni, hogy témavezetőként oly sokszor terelt a helyes útra. Szigorú kérdései a szakmai gondolkodás legelhivatottabb medreibe vitték gondolataimat, és következetesen figyelemmel kísérte minden szárnypróbálgatásomat. Köszönöm továbbá Mészáros Rezső professzor úrnak, akinek köszönhetően el mertem indulni a geográfia még ismeretlen területeire, és akinek közvetett bátorítása nélkül nem kerestem volna fel külföldi szakmai közösségeket, hogy téziseimet megméressem, s a honi geográfia szolgálatára lehessek az IGU Globális Információs Társadalom Földrajza Bizottság tagjaként. Tanáraim közül szeretném még Mezősi Gábor professzor úr nevét megemlíteni, akinek múlhatatlan érdeme van abban, hogy az infokommunikációs technológiával egyetemi éveim kezdetén gyors és szoros barátságot kössek. Nélküle nem vettem volna meg első számítógépemet és nem kezdtem volna el a digitális írástudás alapkompetenciáinak elsajátítását éppen akkor, amikor hazánkban az internet még a távközlő szolgáltatások egyik érdekessége volt csupán.

Nem utolsó sorban szeretnék köszönetet mondani az ITTK kutatóinak, akik geográfus kutatóként befogadtak az információs társadalom rejtelmei iránt érdeklődő közösségükbe, kitárva újabb és újabb kapukat a téma mérhetetlen megismerésének termeiben. Z. Karvalics László, Pintér Róbert, Székely Levente, Rab Árpád megismerése, és rajtuk keresztül Csepeli Györggyel történő beszélgetések olyan „think tank”-ek voltak a számomra, amelyek ismeretelméleti alapozóul szolgálnak a mai napig.

És végül szeretnék köszönetet mondani az IGU Globális Információs Társadalom Földrajza Bizottság tagjainak és a NETCOM szerkesztő bizottság tagjainak. Az ő közreműködésük és folyamatos biztató, baráti támogatásuk nélkül nem lehettem volna a magyar információs társadalom elmúlt évtizedét bemutató tematikus szám szerkesztője. Különösen köszönöm Henry Bakis és Philippe Vidal ösztönző szakmai támogatását és nem utolsó sorban barátságukat, valamint Aharon Kellerman, Maria Paradiso, Peter Graf, Tommi Inkinen és Mark Wilson geográfusok szüntelen érdeklődését munkám iránt, valamint azért, mert a kutatásaikkal példát mutattak és biztattak az értekezés megírására. 


\section{IRODALOM}

ADAMS, PAUL CHANNING (1995): A Reconsideration of Personal Boundaries in Space-Time, Annals of the Association of American Geographers, Volume 85, Issue 2, June, 1995), pp. 267-285.

ADAMS, PAUL CHANNING (1998): Network Topologies and Virtual Place, Annals of the Association of American Geographers, Vol. 88, No. 1, March 1998, pp. 88 -106.

AHLQVIST, TONI - INKINEN, TOMMI (2007): Technology foresight in scalar innovation systems: a spatiotemporal process perspective, Fennia 185: 1, pp. 3-14. Helsinki. ISSN 0015-0010

AITKEN, STUART C. - VALENTINE, GILL (2006): Approaches to human geography, SAGE 2006, In. Contested geographies: culture wars, personal clashes and joining debate, p. 332.

ARMANI, JACOPO - ROCCI, ANDREA (2003): Conceptual Maps in e-learning, How map based interfaces help the contextualization of information and the structuring of knowledge, Information Design Journal \& Document Design; 2002/2003, Vol. 11, Number 3, 2003, pp. 171-184 (14), forrás: http://www.api.adm.br/GRS/referencias/mapaXE-learning.pdf, utolsó elérés: 2010.07.15.

BAKIS, HENRY - DUPUY, GABRIEL ed. (1995b): "Réseaux de communication", Annales de géographie n spécial 585-586, 1995, pp. 451-621

BAKIS, HENRY - ROCHE, EDWARD MOZLEY (1997): Cyberspace - The Emerging Nervous System of Global Society and its Spatial Functions, Cybergeo: European Journal of Geography [En ligne], Systèmes, Modélisation, Géostatistiques, document 59, mis en ligne le 28 mai 1998. URL : http://cybergeo.revues.org/index5342.html

BAKIS, HENRY (2001): Understanding the geocyberspace: a major task for geographers and planners in the next decade, In. Networks and Communication Studies, NETCOM, vol. 15, n 1-2, 2001, p. 9-16

BAKIS, HENRY et al. ed. (1995a): "Expériences et perspectives de la téléactivité", NETCOM, vol. IX, n² (1995), 305-505

BAKOS FERENC (1989): Idegen szavak és kifejezések szótára, Akadémiai Kiadó 1989.

BARABÁSI-ALBERT LÁSZLÓ (2003): Behálózva, A hálózatok új tudománya, Hogyan kapcsolódik minden egymáshoz, és mit jelent ez a tudományban, az üzleti és a mindennapi életben, Magyar Könyvklub 2003.

BATTERSBY, SARAH E. - MONTELLO, DANIEL R. (2009): Area Estimation of World Regions and the Projection of the Global-Scale Cognitive Map, Annals of the Association of American Geographers, 99 (2) 2009, pp. 273-291

BATTY, MICHAEL (1997): Virtual geography, Futures, Vol. 29, 1997, No. 4/5, pp. 337-352.

BATTY, MICHAEL et al. (1998): Modelling Virtual Urban Environments, CASA Working Paper 01, forrás: http://www.casa.ucl.ac.uk/publications/workingPaperDetail.asp?ID=1; utolsó elérés: 2010.08.20.

BENIGER, JAMES R. (2004): Az irányítás forradalma, Az információs társadalom technológiai és gazdasági forrásai, Gondolat - Infónia Kiadó 2004.

BESSENYEI ISTVÁN - TÓTH ZSOLT (2008): A konstruktivista oktatás környezete és a Moodle, NETIS kurzuskönyv, p. 1-17.

BESSENYEI ISTVÁN (2007): Tanulás és tanítás az információs társadalomban, Az eLearning 2.0 és a konnektivizmus, In. Információs társadalom, tankönyv, szerkesztette Pintér Róbert, Gondolat - Új Mandátum Kiadó 2007., pp. 201-211.

BONETT, ALASTAIR (2008): What is geography?, SAGE, London 2008, p. 158.

BUILDING THE KNOWLEDGE SOCIETY: SOCIAL AND HUMAN CAPITAL INTERACTIONS (2003), Commission of the European Communities, Commission staff working paper, Brüsszel 2003.05.28., forrás: http://www.uni-mannheim.de/edz/pdf/sek/2003/sek-2003-0652-en.pdf; utolsó elérés: 2010.09.13.

BUTTIMER, ANNE (1969): Social Space in Interdisciplinary Perspective, American Geographical Society, Geographical Review, Vol. 59, No. 3, July 1969, pp. 417-426. (http://www.jstor.org/pss/213485)

BUTTIMER, ANNE (1976): Grasping the dynamisim of the lifeworld, Annals of the Association of American Geographers, June 1, 1976, pp. 277-292. 
BUTTIMER, ANNE (1980): "Home, Reach and Sense of Place", in The Human Experience of Space and Place, Buttimer, A. and D. Seamon (eds). London: Croom-Helm, 1980.

BUTTIMER, ANNE (1990): Geography, Humanism, and Global Concern, Annals of the Association of American Geographers; March 1990, Vol. 80 Issue 1, p1-33.

BUTTIMER, ANNE (1999): Humanism and Relevance in Geography, Scottish Geographical Journal, June 1, 1999., pp. 103-116.

CAIRNCROSS, FRANCES (1997): The death of distance: how the communications revolution will change our lives, Harvard Business School Press 1997.

CASTELLS, MANUEL (1999): Information Technology, Globalization and Social Development, UNRISD Discussion Paper No. 114, September 1999.

CASTELLS, MANUEL (2005): A hálózati társadalom kialakulása, Az információ kora: Gazdaság, Társadalom és Kultúra. I. kötet, Gondolat - Infónia Kiadó, 2005.

CASTELLS, MANUEL (2006): A tudás világa Manuel Castells, Manuel Castells és Martin Ince beszélgetése, Napvilág Kiadó 2006.

CASTELLS, MANUEL (2007): Az évezred vége, Az információ kora, Gazdaság, társadalom, kultúra III. kötet, Gondolat-Infonia Kiadó 2007.

CLARK, ANDY (1996): A megismerés építőkövei, Osiris Könyvtár, Budapest 1996.

COREY, KENNETH E. - WILSON, MARK I. (2006): Urban and regional technology planning: planning practice in the global knowledge economy, Routledge, 2006

COULESIS, HELEN (1995): Location, place, region and space, In. Geography's inner worlds: pervasive themes in contemporary American geography, szerkesztők: Ronald Abler, Melvin Gerald Marcus, Judy M. Olson, Association of American Geography, Rutgers, The State University 1995, pp. 215-234.

CSÉFALVAY ZOLTÁN (1990): Térképek a fejünkben, Akadémiai Kiadó, Budapest 1990.

CSEPELI GYÖRGY - PRAZSÁK GERGÖ (2010): Örök visszatérés?, Társadalom az információs korban, Jószöveg Mühely 2010

CSERMELY PÉTER (2005): A rejtett hálózatok ereje, Mi segíti a világ stabilitását?, Vince Kiadó 2005.

CSOTÓ, MIHÁLY - SZÉKELY, LEVENTE (2009): Indicators of Internet usage: does the Internet reflect regional inequalities within Hungary?, NETCOM Vol. 23 (2009), No 1-2., pp. 49-62.

DE BONO, EDWARD (2009): Gondolkozz! ... mielőtt túl késő, HVG Kiadó 2009., p. 121.

DOBERS, PETER - HALLIN, ANETTE (2006): Slipping into Darkness: A Study of the Role of ICTs in the Making of Stockholm's Image, Journal of Urban Technology, Volume 13, Number 3, December 2006, pages 119-127.

DODGE, MARTIN - KITCHIN, ROB (2001a): Atlas of Cyberspace, forrás: http://www.kitchin.org/atlas/contents.html, utolsó elérés: 2010.07.15.

DODGE, MARTIN - KITCHIN, ROB (2001b): Mapping cyberspace, Routledge, New York 2001

DOWNS, ROGER M. - STEA, DAVID (2005a): Cognitive Maps and Spatial Behavior: Process and Products, pp. 8-26., In. Roger M. Downs,David Stea, Image \& environment: cognitive mapping and spatial behavior, 2005.

DOWNS, ROGER M. - STEA, DAVID (2005b): Térképek az elmében - Gondolatok a mentális térképezésről (Részlet), In. Letenyei László (szerk.), Településkutatás II., p. 593-614, Szöveggyüjtemény, forrás: http://www.mentalmap.org/files/DownsSteaReszlet.pdf, utolsó elérés: 2010.07.15.

DOWNS, ROGER M. - STEA, DAVID ed. (2005c): Image \& environment: cognitive mapping and spatial behavior, Aldine Transaction 2005, p. 5.

DOWNS, ROGER M. (1970): Geographic space perception: past approaches and future prospects. In C. Board et al., eds., Progress in geography, no. 2, pp.65-108. Arnold, London., In. Cséfalvay 1990.

FARKAS JÁNOS (2002): Információs- vagy tudástársadalom?, Infonia-Aula 2002.

FODOR, JERRY A. - PYLYSHYN, ZENON W. (1988): Connectionism and cognitive architecture: A critical analysis, Cognition, 28/1988, pp. 3-71.

FOREMAN, NIGEL - GILETT, RAPHAEL (1998): A handbook of spatial research paradigms and methodologies, Psychology Press 1998. 
GEOGRÁFUS HÍRLEVÉL (2010): Megalakult az Alkotó Alkalmazott Geográfusok Egyesülete, forrás: Geográfus Hírlevél 18., Szeged, 2010. június 30., forrás: http://geography.hu/hirlevel/geografushirlevel-18_20100630.pdf; utolsó elérés: 2010.07.23., pp. 4-6.

GOLLEDGE, REGINALD G. ed. (1999): Wayfinding behavior: cognitive mapping and other spatial processes, The Johns Hopkins University Press, Baltimora, Maryland 1999

GRAHAM, STEPHEN (2002): FlowCity: Networked Mobilities and the Contemporary Metropolis, Journal of Urban Technology, Volume 9, Number 1, April 2002, pages 1-20.

GRANOVETTER, MARK S. (1973): The Strength of Weak Ties, American Journal of Sociology, Volume 78, Issue 6, May 1973, 1360-1380

HALL, EDWARD TWITCHELL (1996): Rejtett dimenziók, 4. kiadás, Háttér Kiadó 1996

HARVEY, DAVID W. (1990): The condition of postmodernity: an enquiry into the origins of cultural change, Blackwell, Oxford 1990.

HOLT-JENSEN, ARILD (2004): Geography, history and concepts: a student's guide, SAGE Publication Ltd., London 1999, 2000, 2001, 2003, 2004.

HRONSZKY IMRE (2002): Kockázat és innováció, A technika fejlődése társadalmi kontextusban, Arisztotelész, 2002., forrás: http://vmek.oszk.hu/html/vgi/vkereses/vborito2.phtml?id=1548; utolsó elérés: 2010.07.21.

HUDSON-SMITH, ANDREW - BATTY, MICHAEL - CROOKS, ANDREW (2009): Richard MiltonMapping for the Masses Accessing Web 2.0 Through Crowdsourcing, Social Science Computer Review, Volume 27 Issue 4, November 2009 pp. 524-538.

INFORMATION LITERACY COMPETENCY STANDARDS FOR HIGHER EDUCATION (2004), forrás: http://www.ala.org/ala/mgrps/divs/acrl/standards/standards.pdf, utolsó elérés: 2010.07.15.

INKINEN, TOMMI (2003): Information society, citizens and everyday life: does the Internet make a difference in spatial practices?, Fennia 181: 1, pp. 25-33, Helsinki, ISSN 0015-0010

INKINEN, TOMMI (2005): European Coherence and Regional Policy? A Finnish Perspective on the Observed and Reported Territorial Impacts of EU Research and Development Policies, Research briefing, European Planning Studies Vol. 13, No. 7, October 2005 - ISSN 0965-4313 print=ISSN 1469-5944 online $=05=071113-09$, DOI: 10.1080=09654310500242139, 2005 Taylor \& Francis

INKINEN, TOMMI (2006): The Social Construction of the Urban Use of Information Technology: The Case of Tampere, Finland, Journal of Urban Technology, Volume 13, Number 3, December 2006, pages 49-75.

JACKSON, PETER (2006): Thinking Geographically, GEOGRAPHY, Volume 91/3, pp. 199-204.

JAKOBI ÁKOS (2007): Az információs társadalom térbelisége, Regionális Tudományi Tanulmányok, 13. ELTE Regionális Tudományi Tanszék 2007.

JANELLE, DONALD G. (1973): Measuring Human Extensibility in a shrinking world, The Journal of Geography, 1973. május, Vol. 72/5., pp. 8-15.

JOHANSSON, TROELS DEGN (2000): Visualization in Cyber-Geography - Reconsidering cartography's concept of visualization in current usercentric cybergeographic cosmologies, CASA Working Paper 17, forrás: http://www.casa.ucl.ac.uk/publications/workingPaperDetail.asp?ID=17; utolsó elérés: 2010.08.20.

JOHNSTONE, R. J. (2003): Paradigms and revolution or evolution?, In. Agnew, John A. - Livingstone, David N. - Rogers, Alisdair ed. (2003): Human geography: an essential anthology, Blackwell 2003, pp. 37-51.

JOVANOVICS, BOYAN - ROUSSEAU, PETER L. (2005): General Purpose Technologies, NBER Working Paper No. 11093, 2005 január, JEL No. O3, N2, forrás: http://www.nber.org/papers/w11093.pdf, utolsó elérés: 2010.08.26.

KANALAS IMRE (2003a): Az információs fejlettség területi különbségei Magyarországon (eVilág 2003/10)

KANALAS IMRE (2003b): A megyék versenyképessége az információs társadalomban (in: Régiók az Információs társadalomban, szerk. Nagy Gábor és Kanalas Imre, MTA RKK ATI, Kecskemét 2003.)

KEHL DÁNIEL - SIPOS BÉLA (2007): Évszázados trendek és hosszú ciklusok az Amerikai Egyesült Államokban, Kínában és a világgazdaságban, Hitelintézeti szemle, 2007. VI. évf., 3. szám, pp. 248-282.

KELLERMAN, AHARON (1987): Structuration theory and attempts at integration in human geography, Professional Geographer, Volume 39, Nr. 3, August 1987. pp. 267-274. 
KELLERMAN, AHARON (1989): Time, Space, and Society: Geographyical Societal Perspectives, Kluwer Academic Publisher 1989.

KELLERMAN, AHARON (2002a): New York and Los Angeles: Global Leaders of Information Production, Journal of Urban Technology, Volume 9, Number 1, April 2002, pages 21-35.

KELLERMAN, AHARON (2002b): The Internet on earth: a geography of information, Wiley Ltd, England

KELLERMAN, AHARON (2006): Personal mobilities, Routledge 2006.

KELLERMAN, AHARON (2007): Cyberspace Classification and Cognition: Information and Communications Cyberspaces, Journal of Urban Technology, Volume 14, Number 3, December 2007, pp 5-32.

KELLERMAN, AHARON (2009a): Mobile Telephony: Effects On People And Place, Geodate, Volume 22, Number 4, August 2009, pp 6-10.

KELLERMAN, AHARON (2009b): The End of Spatial Reorganization? Urban Landscapes of Personal Mobilities in the Information Age, Journal of Urban Technology, Volume 16, Number 1, April 2009, pp 47-61.

KITCHIN, ROB - FREUNDSCHUH, SCOTT (2002): Cognitive mapping: past, present, and future, Routledge 2002.

KOMENCZI BERTALAN (2002): Információ és társadalom, EKF Líceum Kiadó, Eger 2002.

KUHN, THOMAS S. (2000): A tudományos forradalmak szerkezete, Gondolat Kiadó 2000.

KULCSÁR ZSOLT (2009): Hálózati tanulás, In. Oktatás-Informatika 2009/1., pp. 4-13.

KWAN, MEI-PO (2001): Cyberspatial cognition and individual access to information: the behavioral foundation of cybergeography, Environment and Planning B: Planning and Design 2001, Vol. 28, pp. 21-37.

LETENYEI LÁSZLÓ (2005): Mentális térképek szerkesztése, In. Letenyei László (szerk), Településkutatás I., Szöveggyüjtemény, pp. 147-185., forrás: http://www.mentalmap.org/files/6mentmap.pdf, utolsó elérés: 2010.07.15.

LUKÁCS GÁBOR (2003): A külföldi tőke és az állami szuverenitás kapcsolata a globalizálódó világgazdaságban - elmélet és empíria, PhD értekezés, Budapesti Közgazdaságtudományi és Államigazgatási Egyetem, Nemzetközi kapcsolatok és Világgazdaságtan Tanszék 2003, forrás: http://www.lib.uni-corvinus.hu/phd/lukacs_gabor.pdf; utolsó elérés: 2007.07.30.

LYNCH, KEVIN (1960): The image of the city, MIT and the President and Fellows of Harvard College 1960.

MADDRELL, AVRIL (2009): An interview with Anne Buttimer: an autobiographical window on geographical thought and practice 1965-2005', Gender, Place \& Culture, Vol. 16, No. 6, December 2009, pp. 741 765.

MARK, DAVID M. et al. (1999): Cognitive models of geographical space, International Journal of Geographical Information Science; December 1999, Vol. 13 Issue 8, p747, 28p (szerzők: Mark, David M., Freksa, Christian, Hirtle, Stephen C., Lloyd, Robert, Tversky, Barbara)

MARKÓ LEHEL (1994): A felelősségről, Polis 1994/1, pp. 21-31.

MASSEY, DOREEN (1994): Splace, Place, and Gender, University of Minnesota Press, Minneapolis 2001forrás: http://www.scribd.com/doc/28008745/Massey-D-Space-Place-and-Gender-1994; utolsó elérés: 2010.08.02.

MAYER, HEIKE (2007): What Is the Role of the University in Creating a High-Technology Region?, Journal of Urban Technology, Volume 14, Number 3, December 2007, pp 33-58.

McLUHAN, MARSHALL (2001): A Guttenberg-galaxis, A tipográfiai ember létrejötte, Trezor Kiadó 2001 eredeti cím: Herbert Marshall McLuhan: The Guttenberg Galaxy. The Making of Typographic Man. University of Toronto Press, 1962.

MEASURING THE INFORMATION SOCIETY, THE ICT DEVELOPMENT INDEX (2009), International Telecommunication Union 2009, forrás: http://www.itu.int/net/pressoffice/backgrounders/general/pdf/5.pdf, utolsó elérés: 2010.07.14.

MÉSZÁROS REZSÖ (2000): A társadalomföldrajz gondolatvilága, Szeged 2000

MÉSZÁROS REZSŐ (2003): Kibertér (Hispánia Kiadó, Szeged, 2003)

MITS (2003): Magyar Információs Társadalom Stratégia, Informatikai és Hírközlési Minisztérium, 2003. november 
MONTELLO, DANIEL R. - SUTTON, PAUL C. (2006): An introduction to scientific research methods in geography, SAGE 2006, pp. 17-33.

MONTELLO, DANIEL R. (ed.) (2001): Spatial information theory: foundation of geographic information science; international conference; proceedings / COSIT 2001, Morro Bay, CA, USA. September 1923,2001. Daniel R. Montello (ed.). Springer-Verlag 2001.

MUHAMMAD, SAIM (2006): New Meanings and Measures of accessibility in the Age of Information Technologies, Networks and Communication Studies, NETCOM, Vol. 20, No. 1-2, 2006, pp. 69-90.

NAGY GÁBOR - KANALAS IMRE ed. (2003): Régiók az információs társadalomban. MTA RKK ATI, Kecskemét.

NAGY GÁBOR (2001): Az információs társadalom és az Alföld. Adaptációs esélyek. Alföldi Tanulmányok XVIII. 2000-2001, pp. 90-108. Nagyalföld Alapítvány, Békéscsaba.

NAGY GÁBOR (2002): Területi különbségek az információs korszak küszöbén (Mit mérünk, és hogyan?) Területi Statisztika V/42./(1):3-25.

NAGY GÁBOR (2004): Az Információs Társadalom Magyarországon, Területi különbségek. eVilág III.(2):1015.

NAGY, GÁBOR - KANALAS, IMRE (2009): Development and regional characteristics of the Hungarian information and communication sector (ICT), NETCOM Vol. 23 (2009), No 1-2., pp. 21-48.

NUNES, MARK (2006): Cyberspaces of everyday life, University of Minnesota Press, Minnesota 2006

PARADISO, MARIA (2003): Geography of the information society: A new culture of hybrid space?, Proceedings of the Conference THE CULTURAL TURN IN GEOGRAPHY, 18-20th of September 2003 - Gorizia Campus, Part III: Cultural Geography, Information Systems, forrás: http://www.openstarts.units.it/dspace/bitstream/10077/847/1/c1paradi.pdf, utolsó elérés: 2010.07.15.

PARADISO, MARIA (2006): Information Geography: A Bridge between Engineering and the Social Sciences, Journal of Urban Technology, Volume 13, Number 3, December 2006, pages 77-92.

PEPPER, STEPHEN (1942): World Hypotheses: A Study in Evidence. University of California Press, Berkely 1942.

PINTÉR RÓBERT (2003): Magyarország - a rejtőzködő információs társadalom tézise (eVilág, 2003/10)

PINTÉR RÓBERT (2004): A magyar információs társadalom fejlődése és fejlettsége a fejlesztők szempontjából, Szociológia doktori (Ph.D.) értekezés, Eötvös Loránd Tudományegyetem - Társadalomtudományi Kar 2004, forrás: http://mek.niif.hu/02300/02336/02336.pdf; utolsó elérés: 2010.07.30.

PLÉH CSABA (2002): A transzparencia: a gondolkodás köznapjaitól a kognitív tudományig, In.: Gábor Forrai,Tihamér Margitay (szerk.): Tudomány és történet, Typotex Kft.

PLÉH CSABA ed. (1997): A megismeréskutatás egy új útja: A párhuzamos feldolgozás, TYPOTEX Kiadó, Budapest 1997.

RAB ÁRPÁD (2007): Digitális kultúra, A digitalizált és digitális platformon létrejött kultúra, In. Információs társadalom, tankönyv, szerkesztette Pintér Róbert, Gondolat - Új Mandátum Kiadó 2007., pp. 182-200.

RECHNITZER JÁNOS (2003): Az információs társadalom térformáló szerepe, eVilág, 2003/2

RHEINGOLD, HOWARD (2000): The virtual community: homesteading on the electronic frontier, MIT Press 2000.

SACK, ROBERT DAVID (2001a): The geographic problematic: empirical issues, Norsk geogr. Tidsskr., Oslo. ISSN 0029-1951, September 2001, Vol. 55, pp. 107-116.

SACK, ROBERT DAVID (2001b): The geographic problematic: moral issues, Norsk geogr. Tidsskr., Oslo. ISSN 0029-1951, September 2001, Vol. 55, 117-125.

SHEPPARD, ERIC et al. (1999): Geographies of the information society, International Journal of Geographical Information Science; December 1999, Vol. 13 Issue 8, pp. 797-823, 27p., ed: Sheppard, Eric; Couclelis, Helen; Graham, Stephen; Harrington, J. W.; Onsrud, Harlan.

SIEMENS, GEORGE (2006): Knowing knowledge, forrás: http://www.elearnspace.org/KnowingKnowledge_LowRes.pdf, utolsó elérés: 2010. 07. 14.

SINKA RÓBERT (1999): Intelligens települések a Jászságban - JT-GIS pilot projekt, In. Jászsági évkönyv 1999, pp. 122-131. 
SINKA RÓBERT (2004): Gondolatok az információs társadalom földrajzi diskurzusához. In. Abonyiné Palotás J. - Komarek L. (szerk.) 40 éves a Szegedi Tudományegyetem Gazdaság- és Társadalomföldrajz Tanszék, Szeged, pp. 193-198.

SINKA RÓBERT (2005) Tanítók az információs társadalomban, Informatika a felsőoktatásban Konferencia, Debrecen, 2005. augusztus 24-26. Konferencia kiadvány, ISBN 963472909 6, online forrás: http://agrinf.agr.unideb.hu/if2005/dokumentumok/IF2005-Absztrakt-kotet.pdf; ｕtolsó elérés: 2010.07.25.

SINKA RÓBERT (2006a): Az információs társadalom adaptációjának földrajzi aspektusai a tanítóképzésben, III. Magyar Földrajzi Konferencia, Budapest, 2006. szeptember 6-7. - forrás: http://geography.hu/mfk2006/Absztraktkotet.pdf; utolsó elérés: 2010.09.10.

SINKA, ROBERT (2006b): Accessibility and exclusion in the society of urban and rural areas: the geographical perspective of participation in digital communities in a Hungarian micro region (Jászság), In. NETCOM The role of place in the information age: it use and knowledge creation - Maria Paradiso and Mark Wilson (ed.), Volume XX. 2006, N 1-2; pp. 57-67. - forrás: http://recherche.univmontp3.fr/netcom_labs/volumes/NET201.html; utolsó elérés: 2010.07.25.

SINKA RÓBERT (2006c): A Moodle, mint a digitális írástudás fejlesztésének eszköze a felsőoktatásban, MoodleMoot Konferencia 2006, Debrecen

SINKA RÓBERT (2006d): Mit oktassunk: Moodle-t vagy informatikát?, MoodleMoot Konferencia 2006, Debrecen

SINKA RÓBERT (2007a): Valós és virtuális földrajzi térkategóriák szerepe a földrajz oktatásában, MoodleMoot Konferencia 2007, Debrecen

SINKA, ROBERT (2008a): The influence of the ICT on the geographical thinking, 31th International Geographical Congress, Tunis2008 August 12th - 15th, konferencia elöadás az IGU Commission on Geography of Information Society szekcióban.

SINKA RÓBERT (2008b): A tudatos e-learning fejlesztés recens határai, MoodleMoot Konferencia 2008, Debrecen

SINKA RÓBERT (2009a): E-learning stratégia a gyakorlatban, MoodleMoot Konferencia 2009, Debrecen, forrás: http://www.slideshare.net/moodlekonf/sinka-rbert-elearning-stratgia-a-gyakorlatban; utolsó elérés: 2010.08.26.

SINKA, ROBERT (2009b): The appearance of a new phenomenon in geographic thinking: the influence of ICT, NETCOM Vol. 23 (2009), No 1-2., pp. 111-124.

SINKA, ROBERT (2009c): The formation of the Hungarian Information Society in the last ten years, NETCOM Vol. 23 (2009), No 1-2., pp. 7-20.

SINKA RÓBERT (2010): E-szolgáltatások integrációja intézményi szinten, MoodleMoot Konferencia 2010, Gödöllő

SINKA, ROBERT - PAPP, GYULA - VÁGVÖLGYI, CSABA (2007c): 'Open source information society from beginners to advanced' in the Hungarian education, The possible roles of Moodle in the Hungarian teacher training, Author manuscript, published in "Conference ICL2007, September 26 -28, 2007. Villach, source: http://halshs.archives-ouvertes.fr/docs/00/25/71/54/PDF/271_Final_Paper.pdf; utolsó elérés: 2010.07.23.

SINKA, ROBERT (2005): Accessibility and exclusion in the society of urban and rural areas: the geographical perspective of participation in digital communities in a Hungarian micro region (Jászság), Digital Communities Conference 2005, Benevento - Naples, June 5-10 2005

SINKA, ROBERT (2006e): Primary School Teachers in the Information Society, Journal of Universal Computer Science, vol. 12, no. 9 (2006), 1358-1372, submitted: 31/12/05, accepted: 12/5/06, appeared: 28/9/06, J.UCS; online forrás: http://www.jucs.org/jucs_12_9/primary_school_teachers_in ; utolsó elérés: 2010.07.25.

SINKA, ROBERT (2007b): 'Open source information society’ in the Hungarian higher education, Conference paper - Digital Communities 2007, 08-12, July 2007. Tallinn, Estonia - Helsinki, Finland

SINKA RÓBERT (2011a): A konnektivizmus földrajza, Információs Társadalom folyóirat 2011/3. szám (11. évfolyam) - közlésre elfogadott.

SINKA RÓBERT (2011b): Hozzáférés és kirekesztés a városi és vidéki terekben - a jászsági kistérség lehetőségei az információs társadalomban, Földrajzi Közlemények 2011/3. szám - közlésre elfogadott. 
STEIGER KORNÉL (2009): Polisz, egyén, erény, A Nikomakhoszi Ethika gondolatmenete és szerkezete, Világosság 2009 tavasz, pp. 5-16.; forrás: http://www.vilagossag.hu/pdf/20091214200520.pdf; utolsó elérés: 2010.07.22.

STUDIES IN THE CONTEXT OF THE E-LEARNING INITIATIVE: VIRTUAL MODELS OF EUROPEAN UNIVERSITIES (Lot 1), Draft Final Report to the EU Commission, DG Education \& Culture, Februar 2004

SZAKÁCSNÉ NAGY SZILVIA - KUTOR LÁSZLÓ (2005): Informatika szerepe az információs akadálymentesítés során a látássérültek körében, Informatika a felsőoktatásban Konferencia, Debrecen, 2005. augusztus 24-26. Konferencia kiadvány, ISBN 963472909 6, online forrás: http://agrinf.agr.unideb.hu/if2005/dokumentumok/IF2005-Absztrakt-kotet.pdf; utolsó elérés: 2010.07.25.

SZALAVETZ ANDREA (2006): Új Kondratyev-ciklus a láthatáron, A nanotechnológia gazdasági hatásai, Technológiai fejlődés és új tudományos eredmények, NKTH MECENATÚRA PÁLYÁZAT, Ismeretterjesztő cikksorozat, 2006 július, forrás: http://www.vki.hu/technologia/mec5_nano.pdf, utolsó elérés: 2010.08.26.

TAPSCOTT, DON - WILLIAMS, ANTHONY D. (2007): Wikinómia, Hogyan változtat meg mindent a tömeges együttmüködés, HVG Kiadó 2007.

TOLMAN, EDWARD C. (1948): Cognitive Map sin Rats and Men, American Psychological Association, Psychological Review, 55, 1948, pp. 189-208., In. Roger M. Downs, David Stea: Image \& environment: cognitive mapping and spatial behavior.

TÓTH, MÁTÉ (2009): Pushing the boundaries of accessibility - Governmental efforts on ensuring equal access to information to rural library users (1997-2007), NETCOM Vol. 23 (2009), No 1-2., pp. 85-110.

VARGA CSABA (2003): A fenntartható társadalom esélye, INCO internetes folyóirat, 13. szám, HU ISSN 1588-0729, forrás: http://inco.hu/inco13/global/cikk1h.htm; utolsó elérés: 2010.07.27.

VÉGH ATTILA (2010): A mítosz alkonya, Nagyítás hetilap, Esszé rovat, 2010/25. szám, 2010.06.23.,forrás: http://www.nagyitas.hu/common/main.php?pgid=cikk\&cikk_id=1893\&tema_id=26; utolsó elérés: 2010.07.22.

WARF, BARNEY (2001): Segueways into cyberspace: multiple geographies of the digital divide, Environment and Planning B: Planning and Design 2001, volume 28, pp. 3-19.

WEBSTER, FRANK (2002): Theories of the information society, Routledge 2002

WIENER, NORBERT (1974): Válogatott tanulmányok, Gondolat Kiadó 1974.

YU, HONGBO - SHAW, SHIH-LUNG (2006): Exploring Potential Human Activities in Physical and Virtual Spaces_A Spatio-temporal GIS Approach, forrás: http://www2.geog.okstate.edu/users/HongboYu/NSFProject-Website/publications/Yu_Shaw_2006.pdf, utolsó elérés: 2010.08.26.

YU, HONGBO - SHAW, SHIH-LUNG (2008): A Space-Time GIS Approach to Exploring Large Individualbased Spatiotemporal Datasets, Transactions in GIS, 2008, 12(4): 425-441.

YU, HONGBO (2006): Spatio-temporal GIS Design for Exploring Interactions of Human Activities, Cartography and Geographic Information Science, Vol. 33, No. 1, 2006, pp. 3-19.

Z. KARVALICS LÁSZLÓ (1995): Az általános iskolai informatikaoktatás helyzetének és fejlesztésének általános kérdései. Javaslat egy korszerű informatikai műveltséganyag összetevőire, Kutatási zárótanulmány 1995., Kézirat, forrás: http://ebooks.gutenberg.us/Wordtheque/hu/AAACZH.TXT; utolsó elérés: 2010.07.27.

Z. KARVALICS LÁSZLÓ (1999): A világtársadalom mint információközösség, Norbert Wiener, az információ társadalomelméletének plebejus teoretikusa, In. Neumann Jánostól az Internetig - akik nyomot hagytak a 20. századon 4., Napvilág Kiadó. Budapest 1999., pp. 29-71.

Z. KARVALICS LÁSZLÓ (2002): Az információs társadalom keresése, Infonia-Aula Kiadó, Budapest 2002.

Z. KARVALICS LÁSZLÓ (2007): Információs társadalom - mi az? Egy kifejezés jelentése, története és fogalomkörnyezete, In. Az információs társadalom, tankönyv, szerk. Pintér Róbert, Gondolat - Új Mandátum Kiadó 2007. 


\title{
MELLÉKLET
}

\section{JEGYZETEK}

\begin{abstract}
${ }^{1}$ Egy viszonylag korai munka ebböl az időböl Cairncross (1997): The death of distance: how the communications revolution will change our lives c. könyve. Ma már talán néhol utópisztikus megállapításai, megközelítései az üzleti szférának mutatott „egykoron” utat.

2 Turing-gép 1930-as évek (Alan Mathison Turing), Neumann-elvek 1946 (Neumann János) megjelenését tekintem a kezdeteknek.

3 ,cultural and educational development conditions technological development, which conditions economic development, which conditions social development, and this stimulates cultural and educational development once more. This can be a virtuous circle of development or a downward spiral of underdevelopment. And the direction of the process will not be decided by technology but by society, through its conflictive dynamics.”Manuel Castells: Information Technology, Globalization and Social Development, UNRISD Discussion Paper No. 114, September 1999, p. 13., In.:
\end{abstract}

http://citeseerx.ist.psu.edu/viewdoc/download?doi=10.1.1.130.5730\&rep=rep1\&type=pdf; utolsó elérés: 2010.07.08.; eredeti forrás: http://www.unrisd.org/;

${ }^{4}$ A „hordozó eszközön” itt a technikai megvalósítás tárgyi manifesztációját (legyen az papirusz, könyv, DVD stb.) és a tartalmat együttesen értem. Például a könyvnyomtatás elött is léteztek könyvek, létezett a könyvek sokszorosításának a technikája is. A nyomtatás feltalálása mégis forradalmasította ezt a tudásátadó eszközt. Ebben az értelmezésben nem elsődlegesen a tartalom, hanem az a technológiai megoldás kapta a központi szerepet, amely hatására a „tudást-hordozó” eszköz a térben gyorsabban, nagyobb számossággal, intenzitással és dinamikával terjedhetett. - Később, az elektronikus (konnekcionista) kultúra különböző térformáinak (auditív, tapintási, verbális, vizuális, tipográfiai tér) vizsgálatakor, a fogalom további értelmezési formáira is szükség lesz.

${ }^{5}$ Edward de Bono (2009): Gondolkozz! ... mielőtt túl késő, HVG Kiadó 2009., p. 121.

${ }^{6}$ Honlap: https://www.msu.edu/user/wilsonmm/igu.html

${ }^{7}$ KSH portál: http://portal.ksh.hu/portal/page?_pageid=37,447530\&_dad=portal\&_schema=PORTAL

${ }^{8}$ Információs Társadalom- és Trendkutató Központ (ITTK): http://ittk.hu/web/kiadvanyok.html

${ }^{9}$ World Internet Projekt (ITTK WIP): http://www.ittk.hu/web/wip.html

${ }^{10}$ Eurostat adatbázis: http://portal.ksh.hu/pls/ksh/docs/hun/eurostat_tablak/index.html

${ }^{11}$ Arild Holt-Jensen (2004): Geography, history and concepts: a student's guide c. munkájának harmadik fejezete a Paradigmák és forradalmak címet viseli, melyben - bár főleg az amerikai geográfusok munkáira hivatkozva - hasonló utat jár be, mint Cséfalvay Zoltán. Érdekessége, hogy a fejezet végén megfogalmazza a forradalom vagy evolúció (revolution or evolution) problémakörét, és hangsúlyozza Widberg négy, a tudományos gondolkodás története szempontjából alapvető, de eltérő nézőpontját (pp. 97-98). Ezek között akad olyan, amelyik a forradalmi és akad, amelyik az evolúciós szemlélet mellet tör lándzsát.

${ }^{12}$ R. J. Johnston is hasonló problémákat jár körül a Paradigms and Revolution or Evolution? címü írásában, különösen a The Environments of Change és az azt követö alfejezetben (pp. 45-48). (In. Human geography: an essential anthology (2003), (pp. 37-53).

13 2003-ban ismerkedtem meg az ITTK ITOK hálózatának tagjaival, és 2004-től már a jászberényi tanítóképző főiskolán megalapítottam a helyi ITOK központot, amely 2008-ig müködött. Ez vezetett oda, hogy 2005-ben az addigi kutatásaimat nemzetközi területen is megmutassam.

14 2008-tól Globális Információs Társadalom Földrajza Bizottság az elnevezés, előtte nem volt a nevében a 'globális’ kifejezés. A döntést már a szakbizottság tagjaként kísérhettem figyelemmel a tuniszi 31. Nemzetközi Földrajzi Konferencián, a bizottság tisztújító közgyülésén. A döntés oka, célja szakmai és politikai is volt. A szakmai okok mögött elsősorban az állt, hogy az IGU ezen szakbizottságának a kutatói munkája egyre kevésbé volt országhatárok és regionális keretek között megfogalmazható. Az információs társadalom globális kiterjedésű változás, amelyet az ezzel foglalkozó szakmai közösségeknek nevükben is képviselni kell. A politikai jellegü döntést pedig azzal lehetett indokolni, hogy a globális változások nem csak hogy átszövik a társadalmigazdasági folyamatokat, de a hétköznapi élet legapróbb mozzanatait is átformálják, alakítják. A névváltozás egyben nyitást is jelentett más IGU bizottságok és kutatóműhelyek munkái felé, megcélozva a jövőben közös, integráltabb kutatási projektek létrejöttét. A megfogalmazott irányok között említhetők közös kutatási programok, konferenciák, workshopok szervezése egymás munkáinak jobb megismerését szolgálva. A kapocs 
minden esetben: az információs társadalom kutatása, felismerve a tényt, hogy a földrajzi szemléletű társbizottságok és a geográfia társtudományai is egyre több, értékes eredménnyel álltak elő az elmúlt években. Ezek megismerése a földrajzi kutatások tudományos megújulásának egyik lehetősége lehet.

${ }^{15}$ Metakogníció: a saját tudásunkról rendelkezésre álló tudás, amelyet a hosszú távú emlékezetben tárolunk; a saját tudásunk müködtetésének ellenőrzése.

${ }^{16}$ Az információ természetéhez tartozik, hogy hosszan nem tárolható, elavul, értékét jelentősen elveszítheti, ezért tovább kell adni, ami dinamikát kölcsönöz neki.

${ }^{17}$ A felületesség ott kap eredeti jelentésében szerepet, amikor túlzott tudományos megfogalmazásai miatt az érdeklődés passzivitásba menekül.

${ }^{18}$ Az idézett szöveg elhangzott az Alkotó Alkalmazott Geográfusok Egyesülete alakuló ülésén, Budapesten, az MTA Kutatóházában, 2010. március 30-án., forrás: http://geography.hu/hirlevel/geografus-hirlevel18_20100630.pdf; utolsó elérés: 2010.07.18.

${ }^{19}$ Ebben az esetben merjük feltételezni a technológiai változások által generált környezeti szemléletváltás lehetőségét, merjük megfogalmazni azt a tézist, hogy az információfeldolgozást és közvetítést forradalmasító újítások igenis forradalmi hatással voltak (lehetnek) a társadalmi gondolkodás fejlődésére. Az írásbeliség megjelenésétől a könyvnyomtatáson át az információs társadalom eszközrendszeréig találhatunk ilyen eszközöket.

${ }^{20}$ Az áttekintéshez Cséfalvay Zoltán, Térkép a fejünkben c. munkáját használtam mankóként.

${ }^{21}$ Napjainkban is él az a felfogás a magyar közoktatásban (tanulók, szülök és nem szakos tanárok körében) és közgondolkodásban, hogy a földrajz nem tudomány, hanem csupán az érdekes tájak és emberek bemutatására szolgáló kellemes időtöltés egyik formája.

${ }^{22}$ Nem véletlen, hogy a geográfiai ismeretek bővülése, új irányzatok megjelenése gyakran éppen a hódító államok geográfusaihoz kötödött.

23 „Even in the information economy, geography matters!” - Goddard 1990, p. xvii, In. A. Kellerman, The Internet on earth: a geography of information, 2002, p. 1.

${ }^{24}$ A Maslow-i szükséglet-piramis legalsó fokát jelentik. A környezet megismerése, feltérképezése a létfenntartást szolgálta. Csak a piramis legfelső szintjein jelenhet meg az igény arra, hogy megválaszoljuk a miérteket is.

${ }^{25}$ Norbert Wiener (1896-1964), Németországból az USA-ba emigrált matematikus, a kibernetika atyja.

${ }^{26}$ Norbert Wiener: Kibernetika és pszichopatológia, In. Norbert Wiener: Válogatott tanulmányok, Gondolat Kiadó 1974., pp. 144-170. (Eredeti kiadás és cím: Cybernetics, II. kiadás, The MIT Press and John Wiley and Sons, Inc., New York - London, 1961.)

${ }^{27}$ Az információfeldolgozás csoportszintjeiről A tér és hely, tipológiai kísérletek c. fejezetben lesz részletesebben szó.

${ }^{28}$ Ez a Maslow-i szükséglet-piramis két alsó szintje: a fizikai és a biztonsági szükséglet igénye. Ez a két szint több-kevésbé megfeleltethető Wiener információközösségen alapuló csoportszintjeinek első két szintjével. Mindez szoros kapcsolatot feltételez az alapvető emberi szükségletek, az emberi csoportok tagjainak száma és az általuk birtokolt információkészlet között. Az információkészlet egyéni és csoportszintje pedig arányos a birtokolt terület nagyságától is, lényegében a térszeletekről rendelkezésre álló földrajzi információkkal.

${ }^{29}$ A csoportelméletek gyakorta ezt mikro szintnek nevezik, és a két-három főre is redukálhatónak tartják. Kéttagú, pont-pont kapcsolatot talán még túlzás lenne hálózatnak tekinteni, de az egyik legfontosabb hálózati elem már itt létrejöhet: a pont-pont kapcsolat, vagyis akár két ember információközössége.

${ }^{30}$ Elkerülhetetlen, hogy ne tegyünk említést az információkezelés alaptechnikáiról: összegyüjteni, rendszerezni, feldolgozni, újrahasznosítani és megosztani. Fontos eleme lesz a dolgozat szintézisében.

${ }^{31}$ Lásd a fejezet elején tett kitérőt, Csatári Bálint földrajzi tudásfelhalmozásra tett megjegyzését.

${ }^{32}$ Mindenesetre elgondolkodtató, hogy bár az egyén tudásszintje, információkészlete magas is lehet, ezt a közösség ritkán képes kihasználni. „Az állam butább, mint legtöbb polgára”, ami annak az anti-homeosztatikus ténynek köszönhető, hogy a csoport valamennyi tagja nem rendelkezhet minden információval, lévén nem jut hozzá a közvetítő eszközökhöz sem. Elvben az állam az, amely a legtöbb információhoz hozzájuthat, birtokolhatná az tudást. A megoldáshoz azonban el kell érnie a megosztást, azt, hogy az egyének és a csoportok megosszák információkészletüket, ami a jelenleg általánosan jellemző birtoklási szisztémát válthatná fel. Az IKT eszközök ebben játszhatnak igen fontos szerepet, mint ahogy a web 2-es eszközök és a hálózati tanulás egyre inkább ebbe az irányba is mutatnak. Lásd még a konnektivizmussal és a hálózattal kapcsolatos fejezeteket. 
${ }^{33}$ Hoyer, Svennik (1931), professor emeritus az Oslói Egyetem Média és Kommunikáció Tanszékén.

Fontosabb angol nyelvű müvei: Towards a Civil Society. The Baltic Media's Long Road to Freedom (Tartu: Nota Baltica, 1993); The Politics and Economics of the Press. A Developmental Perspective (Beverly Hills: Sage, 1975).

${ }^{34}$ Herbert Marshall McLuhan, (1911 - 1980) kanadai pedagógus, filozófus, tudós, az angol irodalom professzora, irodalomkritikus, szónok, a modern kommunikáció teoretikusa.

${ }^{35}$ S. Hoyer (2001): Media on the Eve of the Third Millenium. Comparing Revolutions in Communication. In: Zassoursky, Yassen N. \& Vartanova, Elena (eds.) Changing Media and Communications. Moscow: Faculty of Journalism/Publisher ICAR, 1998. - In. Média a harmadik évezred küszöbén, 2001 tél, pp. 1-8., forrás: http://www.mediakutato.hu/cikk/2001_04_tel/02_media_a_harmadik_evezred_kuszoben/01.html; utolsó elérés: 2010.07.20.

36 Thornstein Veblen (1857-1929) norvég-amerikai szociológus-közgazdász, gazdaságtörténeti gondolkodó használja elsőként a „technológiai determinizmus” kifejezést. A fogalom lelkes hívei közül Mashall McLuhan (Understanding Media 1964), míg az ellentáborból Norbert Wiener (1974) nevét érdemes említeni, aki a „technológiai semlegesség” híveként a technikai eszközök önmagukban való semlegességét hangsúlyozta.

${ }^{37}$ Manuel Castells: Information Technology, Globalization and Social Development, UNRISD Discussion Paper No. 114, September 1999, p. 13.

${ }^{38}$ Természetesen Wiener is rájött, hogy a megosztás nem univerzális, és egy-egy csoportmintázatra, adott csoport alakzatra érvényes csupán. Ehhez kapcsolódóan a konnektivista földrajz tárgyalásában szót kell ejtenünk a brain-drain (agyrablás), a brain-gain (agy visszanyerés) és a brain sharing (agy megosztás) problémaköréről, példakánt említve például a mutual compatibility (kölcsönös megfeleltetés) globális problémáját, amely a hálózati társadalom fejlődésének, a hálózati gondolkodás létrejöttének, és így egyértelmüen a konnektivista paradigma melegágyának tekinthető.

${ }^{39}$ Nílus vidéke: Szóthisz a Nílus áradásának megindítója, Hapi a Nílus istene, Anuket a nílusi zuhatagok védelmezője; Mezopotámia: Enki az édesvíz és a csatornák istene; Maja kultúra: Csak (jelentése: balta) az eső és a villámlás istene; Azték kultúra: Sipe-Totek (Chipe-Totec) (jelentése: megnyúzott urunk) a tavasszal újjászülető növények istene, stb.

${ }^{40}$ A görög gyarmatosítás (i.e. 8-6. század, a Földközi-tenger medencéjében) is a földrajz tudomány előtérbe kerülését, virágzását hozta. Érdemes megemlíteni, hogy az ábécé is ekkor, ie. 700 körül jelenik meg Görögországban. (Castells 2005, p. 433.)

${ }^{41}$ Főként a filozófia és a történelem keretein belül müködött. Tovább nehezítette a tudomány fejlődését az, hogy számos önálló tudományága született belőle, amelyek mind megválaszolták a maguk kérdéseit. A földrajznak megmaradt a leíró jellege. (Cséfalvay 1990, p. 30.) A földrajz negligálására napjainkban is találunk számos törekvést a magyar oktatási rendszerben.

${ }^{42}$ A kezdeti lökést Fred K. Schaefer: Exceptionalism in geography: A Methodological Examination (1953) címü tanulmánya adja meg.

${ }^{43}$ Norbert Wiener és Ludwig von Bertalanffy hatására.

${ }^{44}$ Kevin Lynch: The image of the city (Lynch 1960), Edward T. Hall: The hidden dimension (T. Hall 1966)

${ }^{45}$ Sokan felteszik a kérdést: ez már pszichológia vagy még földrajz? Valójában mindkettő. Olyan új irányzat, amely számos eddig megválaszolatlan úm. térbeli rejtélyt igyekszik megmagyarázni.

${ }^{46}$ Aharon Kellerman munkái (1987, 1989, 2002ab, 2009a).

${ }^{47}$ Lásd még itt Daniel R. Montello (ed.) (2001): Spatial information theory: foundation of geographic information science; international conference; proceedings / COSIT 2001, Morro Bay, CA, USA. September 1923,2001. Daniel R. Montello (ed.). Springer-Verlag 2001., és Kevin Lynch (1960): The image of the city, MIT and the President and Fellows of Harvard College 1960. c. munkáit.

${ }^{48}$ Ebben részben ismét régi-új házasságokat köt a földrajz: a szociológia (Manuel Castells), a matematikakibernetika (Norbert Wiener), és az antropológia (Edward T. Hall) eredményeit is felhasználva.

${ }^{49}$ A szociologizáló irányzatok sokat segítettek abban, hogy a térbeli folyamatokat az ember térbeli magatartásának és a környezetének viszonyrendszerében vizsgálhassuk. (Cséfalvay 1990, p. 50.)

${ }^{50}$ Martin G. Plattcl: Social Philosophy (Pittsburgh, 1965); A. C. de Waehlens: L'existentialisme de MerleauPonty (Brussels, 1963), In. Buttimer 1969.

${ }^{53}$ Edward T. Hall: The Silent Language (Premier Books; New York, 1965). See also idem: The Hidden Dimension (Garden City, N. Y., 1966), In. Buttimer 1969. 
52 Paul Claval: Géographie et psychologic des peuples, Rev. de Psychologie des Peuples, Vol. 21, 1966, pp. 386-401; idem: Essai sur l'évolution de la géographie humaine (Paris, 1964). See also R. W. Kates and J. F. Wohlwill, edits.: Man's Response to the Physical Environment, Journ. of Social Issues, Vol. 22, No. 4, 1966., In. Buttimer 1969.

53 „Dramatic and exciting challenges confront geographers today. Revolutionary changes in empirical social patterns have spelled obsolescence for many traditional analytical procedures; radical transformations in the scholastic world have raised questions concerning the philosophical basis of social-science procedures.

Behaviorists and existentialists pose the fundamental question: can science continue to serve a useful function by measuring and explaining the objective face and underlying mechanics of social reality, or must it also penetrate and incorporate its subjective dimensions? ${ }^{53}$ As Edward T. Hall ${ }^{53}$ so convincingly poses it: does time talk, does space speak? How does the silent language of time and space influence mankind's cultural variations? Geographers ask themselves: should we be satisfied with drafting an opaque, objective map of social patterns in

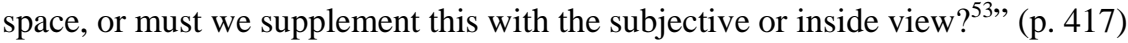

${ }^{54}$ Stephen C. Pepper (1942): World Hypotheses: A Study in Evidence. University of California Press, Berkely 1942.

${ }^{55}$ Nem beszél az ötödik elméletről, amelyet Pepper későbbi munkáiban vezet be, és udvariasan csak „szelektivizmusnak” (selectivism) nevez. Forrás: https://people.sunyit.edu/ harrell/Pepper/Index.htm; utolsó elérés: 2010.07.23.

${ }^{56}$ A formalista metodológiát az információs társadalom diszkussziójánál sem nélkülözhetjük, különösen amióta a fizikai térben realizálható elemeket a virtuális vetületükben is láthatóvá tehetjük. Talán megmosolyogtató, de kijelenthetjük, hogy sokat segített magán a kutatás tárgya (az információs társadalom) éppen azzal, hogy fejlődése során lényegében kutathatóvá tette önmagát (egyre tökéletesebb grafikai és virtualizációs megjelenítő eszközök által). De erről részletesebben a következő fejezetben lesz szó.

${ }^{57}$ A kontextualizmust egyes helyeken pragmatizmusnak nevezi S. C. Pepper. A pragmatizmus pedig eredendően amerikai irányzatnak számít, melynek gondolkodói úgy vélték, az emberiség nagy eszméinek és gondolatainak igazságát és helyességét a gyakorlat, a mindennapi élet, a cselekvések és az eredmények tesztelik.

${ }^{58}$ A korábban uralkodó paradigma leváltását, majd egy zürzavaros, átmeneti periódus után újjal való felváltását nevezi Kuhn "tudományos forradalom"-nak. (Kuhn 2000, p. 86.). Hasonlóképpen érvel Kuhn paradigma koncepciójáról Johnstone is (2003, pp. 48-50.): Paradigms and revolution or evolution? c. cikkében.

59 „Buttimer developed the three interpretive themes of meaning, metaphor and milieu: meaning refers to vocational choice, work or professional activity; metaphor to cognitive style/world view; and milieu to both the environmental features of an author's own childhood and formative years and the public interests served by one’s research activities (Buttimer 1983a, 2001a, 34).” - In. Maddrell 2009, p. 6.

${ }^{60}$ Anne Buttimer (1990): Geography, Humanism, and Global Concern, Annals of the Association of American Geographers; March 1990, Vol. 80 Issue 1, p1-33.

${ }^{61}$ Homérosz eposzaiban az eredendő mondás az eredendő tettet szólítja, és a borzalmasan ingatag emberi létezés így nyeri el pillanatnyi szilárdságának ragyogását. - írja Végh Attila: A mítosz alkonya c. cikkében. Forrás: Nagyítás, Esszé rovat, 2010/25. szám, 2010.06.23., forrás:

http://www.nagyitas.hu/common/main.php?pgid=cikk\&cikk_id=1893\&tema_id=26; utolsó elérés: 2010.07.22. Végh 2010.

${ }^{62}$ Platón ezt már elveti, és nem az ergon, hanem a logosz lesz a müthosz ellentéte. - Végh 2010.

${ }^{63}$ Steiger Kornél: Polisz, egyén, erény, A Nikomakhoszi Ethika gondolatmenete és szerkezete, Világosság 2009 tavasz, pp. 5-16.; forrás: http://www.vilagossag.hu/pdf/20091214200520.pdf; utolsó elérés: 2010.07.22.

${ }^{64}$ Bakos Ferenc (1989): Idegen szavak és kifejezések szótára, Akadémiai Kiadó 1989., p. 617.

${ }^{65}$ Markó Lehel (1994): A felelősségről, Polis, 1994/1, pp. 21-31.

${ }^{66}$ Lásd Karl Ruppert müncheni iskoláját. Az iskola két alapgondolat köré szerveződött: (1) a társadalom nem homogén egész, hanem rétegzett; (2) az építészet funkciókészletének adaptációjával hét kialakított társadalmi alapfunkciók készletet hoztak létre, és e köré szervezték az ember hétköznapi tevékenységét, s ezt tüzte ki kutatási céljául.

${ }^{67}$ Ilyen irányzatok nem csak a müncheni iskola hatására: a szociálgeográfia, időföldrajz, szabadidő földrajz, feminista földrajz, nemek földrajza, városszerkezeti modellek, szociálökológiai irányzatok stb.

${ }^{68}$ A kapcsolódó és meghatározó alapművek között kell említenünk Edward T. Hall (1996) Rejtett dimenziók c. könyvét (eredeti kiadás 1966) és Kevin Lynch (1960) The image of the City c. tanulmányát.

${ }^{69}$ A Bevezetésben tett kitérő a közföldrajz gondolatáról, éppen ezt az „érettséget”, időszerüséget jelenti. 
${ }^{70}$ Nincs tévedés! A földrajzi gondolkodás fejlődésének nem csak geográfiai vetülete létezik, hanem pedagógiai is. Kivételes történés viszont, hogy míg a behaviorista pedagógia megelözte a konstruktivista és újabban konnektivista pedagógiának nevezett irányzatokat (Bessenyei 2008 p. 7.), a geográfiai paradigmákkal párhuzamot mutatnak. Természetesen megtaláljuk a szociológia születésével együtt a szociálpedagógiai irányzatokat is, igaz, hogy jóval hamarabb, már a 20. század elején feltủnnek, míg a szociologizáló földrajzi irányzatok csak ötven évvel később öltenek testet. A sorrend azonban azonos! Érdemes észrevenni azt a castellsi gondolatot, melyet már idéztem a társadalmi - gazdasági - kulturális-oktatási folyamat körfolyamataként. (Castells 1999)

${ }^{71}$ Sinka (2008a): The influence of the ICT on the geographical thinking, 31th International Geographical Congress, Tunis2008 August 12th - 15th, konferencia előadás az IGU Commission on Geography of Information Society szekcióban.

${ }^{72}$ Hasonlóan meghatározó munkák voltak számomra Dodge és Kitchin (2001a, 2001b) kibertér térképei, amelyek láthatóvá tették amiről Gibson még csak álmodott, és Rechnitzer (2003) írásai is. Az egyre bővülő szakirodalom másik gyöngyszeme Mark Nunes (2006): Cyberspaces of everyday life c. munkája.

${ }^{73}$ Sinka (2006b): Accessibility and exclusion in the society of urban and rural areas: the geographical perspective of participation in digital communities in a Hungarian micro region (Jászság), In. NETCOM The role of place in the information age: it use and knowledge creation - Maria Paradiso and Mark Wilson (ed.), Volume XX. 2006, N 1-2;

${ }^{74}$ Itt fogalomhalmozásnak tünik az „átjáró, ablak, kapu” kifejezés. Valójában éppúgy van közöttük különbség, mint ahogy a fizikai térben használjuk ezeket a fogalmakat. Még inkább előtűnik ez, ha a két tér közözz szeretnénk kapcsolatot létesíteni.

${ }^{75}$ Humán Interfész Rés, saját fordításomban Human Interface Gap - HIG. Az általam alkotott fogalom értelmezéséről a későbbi fejezetekben részletesen esik szó.

${ }^{76} 2004$ óta üzemeltetek e-learnig keretrendszereket és 2008 óta e-portfólió rendszereket is. Az itt készülő, jobbára éves riportok adják a kutatás ide vonatkozó adatbázisát, empirikus alapját.

${ }^{77}$ Æsahættr: a titokzatos kés neve Philip Pullman Az Úr sötét anyagai c. trilógiájában.

${ }^{78}$ Ez a kissé filozofikus mondat számos olyan problémát is magában rejt: a hálózatok átjárhatósága, az adatok hozzáférésének joga, a digitális írástudás kompetencia kérdése, a web jogi szabályozása, az internethasználat napi rutinja, a web idő-földrajza, web használat kor - nem - iskolai végzettség szerint stb.

${ }^{79}$ Kurt Koffka (1886 - 1941) német pszichológus, aki később amerikában élt és dolgozott. Az ún. gestalt pszihológia (alaklélektan) megalkotója, leghíresebb művei közé sorolják a Perception: An Introduction to the Gestalt Theorie c. munkáját (Kurt Koffka (1922): Perception: An introduction to the Gestalt-Theorie"; forrás: http://psychclassics.yorku.ca/Koffka/Perception/intro.htm; utolsó elérés: 2010.07.26.)

${ }^{80}$ Edward Chace Tolman (1886 - 1959), az egyik leghíresebb amerikai behaviorista pszichológus. Egyik leghíresebb műve a Cognitive maps in rats and men (Tolman, E. C. (1948): Psychological Review, 55, 189-208., forrás: http://psychclassics.yorku.ca/Tolman/Maps/maps.htm; utolsó elérés: 2010.07.26.).

${ }^{81}$ A behaviorista paradigma és munkáik ebben a kontextusban az antropocentrikus megközelítés erősödése szempontjából lényegesek, a továbbgondolkodást segítik, és nem módszertanuk részletei a hangsúlyosak e pillanatban az összefüggések megértésében.

${ }^{82}$ „A geográfia a görög kezdetek óta az euklidészi - metrikus térfogalomra, később pedig a newtoni értelmezésre épült. E felfogás szerint a tér változatlan, abszolút képződmény, a dolgok háromdimenziós kerete." (Cséfalvay 1990, p. 47.)

${ }^{83}$ Erről részletesebben lásd még A kognitív architektúrák c. fejezetet.

${ }^{84}$ „A látás, mint tudjuk, komplex érzékelés, amely magába foglalja a két szem segítségével történő térérzékelést, a távolságbecslést, a részletek-, szín-, forma-, valamint a kontrasztérzékelésnek és a tárgyak megkülönböztetésének a képességét.” (Sz. Nagy és Kutor 2005) Hajlamosak lehetünk arra, hogy az észlelést, a környezetünkről gyüjtött információkat kizárólag a látáshoz kössük. Nos, vitathatatlan, hogy ezzel az érzékszervünkkel fogadjuk be a legtöbb információt környezetünkröl, azonban ez csak alapesetben igaz. Például egy látásában korlátozott ember esetében köztudott, hogy a többi érzékszerv erősödését, szenzorjainak érzékenyebbé válását tapasztalhatjuk. Ugyanez történik például mély alvás esetében is, amikor nem a látás, hanem a többi érzékszerv veszi át az észlelési föszerepet, érezve hideget, idegen hangokat, légnyomás változását stb.

${ }^{85}$ Vegyük észre az antropocentrikus szemléletmódot, figyelve a „,bennünk lévő világkép”, „,bennünket körülvevő környezet” kifejezésekre. Az ehhez kapcsolódó magyarázatoknak jelentősége lesz a további fejezetek tárgyalásánál is. 
${ }^{86}$ „Behavior takes place in a behavioral environment, by which it is regulated. The behavioral environment depends upon two sets of conditions, one inherent in the geographical environment, one in the organism. But it is also meaningful to say that behavior takes place in a geographical environment ... (1) Since the behavioral environment depends upon the geographical, our proposition connects behavior with a remote instead of an immediate cause ... (2) the results of the animal's behavior depends not only upon his behavioral but also on his geographical environment. ... The geographical environment, not only the behavioral, is changed through all behavior.” (Koffka 1935, p. 31, in.: Dows és Stea 2005c, p. 5.)

${ }^{87}$ Norbert Wiener információközösségen alapuló csoportszintjei négy szintre tagolódnak: az egyéni információkészlet az 1. szint, a minimum kétfös csoportoktól a nagyobb közösségekig létrejövő csoportok alkotják a 2. szintet, az egyes csoportok (csoport thesaurusok) metszetében létrejövő kisebb-nagyobb információközösségek a 3. szinten keletkeznek, az emberi faj közös információkészletét a 4. szint jeleníti meg. (Wiener 1974, in. Z. Karvalics 2002, p. 49.)

${ }^{88}$ Varga Csaba ún. új paradigma-hipotézisei közül érdemes néhányat megemlíteni itt a kollektív tudattal kapcsolatban: „(1.) [...] A szuverén személy léte éppen úgy hozzá kötött a társadalomhoz, mint a szintén szuverén természethez. (2.) A társadalom többek között nem csak a) épített, második környezet, b) közösségi szövet, szerkezet és hálózat, c) intézményes állam, s önkormányzat, hanem elsősorban a társadalom kollektív tudata. (3.) A társadalom nem csak az emberen kívül van, hanem belül is. A társadalom és kollektív tudata beépült az emberi testbe, az idegrendszerbe, az elmébe és az egyén tudatába is. Az emberben is a természet, társadalom és tudat: egy. (4.) Az ember és a társadalom egyaránt nem csak fizikai, hanem végtelenül összetett poszt-fizikai (szellemi, kulturális, tudati vagy például transzcendens) valóság is. Az elöbbi paradigmákból következik, hogy minden valóságréteg (tehát természet, ember, társadalom, szellem, stb.) sokrétegü anyagi/tudati valóságvektor.” - Varga Csaba: A fenntartható társadalom esélye, INCO internetes folyóirat, 13. szám, HU ISSN 1588-0729, forrás: http://inco.hu/inco13/global/cikk1h.htm; utolsó elérés: 2010.07.27.

${ }^{89}$ Lásd újra a fejezetben fentebb Koffka gondolatait. (Koffka 1935, p. 31, in.: Dows és Stea 2005c, p. 5.)

${ }^{90}$ A térbeli elszigeteltség megvalósulhat a valós és virtuális térben is. Az információs korhoz kapcsolódó elszigetelődés összefoglalható a digitális szakadék fogalmával is, jelezve hogy egy több dimenziós metaforáról van szó, amely fogalmi jelentéshordozóként időben és térben nem állandó, ezért sablonos alkalmazása felelőtlenség, szociológiai és geográfiai beágyazottság nélkül (az egyik leggyakoribb) gazdasági magyarázata is testetlen.

${ }^{91}$ Magyarázat: A világ népessége kb. 1975-ben lépte át a 4 milliárdos létszámot, míg 2002-ben meghaladta a 6,2 milliárd föt. A közölt táblázat Z. Karvalics László szerint az Andréka - Németi szerzőpáros egy 1988-as publikációjának figyelembevételével készült, ezért feltételezhető, hogy az akkoriban az 5 milliárdot még csak megközelítő lélekszám helyett is egy korábbi adatot vett figyelembe az említett forrás. A megjelölt forrás: Andréka Hajnal - Németi István (1988): A számítástudomány alapjai: alapkutatás, Filozófiai Figyelö /4 26-55.o.

${ }^{92}$ Az eszközfüggő hálózati topológia tipikus esete. Adott fejlettségi szinten, adott eszközökkel determináns hálózati topológia és virtualizáció valósítható meg. Ennek a problémának a kiegyenlítésére fogalmazódik meg a kilencvenes évek közepére a technológiában a mutual compatibility, és a hátteret biztosító tudásban a brain sharing üzleti elve, később modellje. (Z. Karvalics 1999, p. 52.)

${ }^{93}$ A human interface egy általam definiált olyan tudati képesség, amely segítségével az egyén (mint egyedi entitás) a társadalom tagjaként képes az információközösség bármely tagjával kapcsolatba kerülni, rendelkezik a szükséges információkezelési technikákkal (kommunikációs, nyelvi, müszaki technológia stb.), illetve képes új (belső és külső) információközösség(ek) létrehozására is.

${ }^{94}$ Ezzel összhangban áll E. T. Hall gondolata, miszerint: „Az ember esetében a csoport hatásszférájának méreteit erősen megnöveli a telefon, a tv és a hordozható rádió adóvevő, amelyek lehetővé teszik nagy távolságokban is a csoporttevékenység összehangolását. A csoport hatásszférájának gyors ütemű bővülése napjainkban radikálisan átalakítja társadalmi és politikai intézményeinket; [...]” (Hall 1996, p. 28.)

${ }^{95}$ Az információs társadalom területi kiegyenlítését szolgáló területfejlesztési programok egyik sarkalatos problémája volt az a felfogás, amelyet nálunk iparilag-technológiailag fejlettebb államoktól vettünk át, s amelyek jelentős része mára - éppen az említett anti-homeosztatikus hatás miatt - negligálódott. Klasszikus példa a Sulinet program elemei, a közigazgatás informatizálása, vagy épp napjainkban az ún. IKT kompetencia fejlesztésére kiírt pályázatok eszközbeszerzései.

${ }^{96}$ Lásd például a 2001-ben alapított Információs társadalom c. folyóirat 2001-2003 között, és azóta megjelent cikkeit, vagy az INCO internetes folyóirat és az eVilág ez időben megjelent publikációit.

${ }^{97}$ Ráadásul a nálunk oly sokszor jellemző megkésettség itt is éreztette hatását, bár ezt inkább előnyként publikálta a politika, amellyel „technológiai ugrást” is vihetünk véghez, megelőzve azokat, akik a hagyományos 
utat járják be. Amiért ez nem következett be, annak sajnos nem csak a döntéshozók az okai, s ennek néhány aspektusáról később esik még szó.

${ }^{98}$ Peter Jackson, az angliai Sheffield Egyetem geográfus professzora.

99 „... this article presents an argument for the power of thinking geographically, emphasising the discipline’s grammar (its concepts and theories) as well as its vocabulary (a virtually endless list of place-names).” (Jackson 2006, p. 199.)

${ }^{100}$ Az alapvető tudományos érveléseket lásd még Montello és Sutton (2006): An introduction to scientific research methods in geography c. könyvének ide vonatkozó részében. (pp. 17-33.)

101 Tuan, Yi-Fu (1977): Space and Place: The perspective of experience, Minneapolis, University of Minnesota Press 1977.

102 Példaként említhetem Bugovics Zoltán (2007): Társadalom, identitás és területfejlesztés: a területi identitás és a regionalitás kapcsolata c. munkáját.

${ }^{103}$ Massey, Doreen (2004): Geographies of responsibility, Geografiska Annaler Series B: Human Geography; 2004, Vol. 86, Issue 1, pp. 5-18.

${ }^{104}$ Harvey, David (1989): The Condition of Postmodernity. Oxford: Basil Blackwell, 1989.

${ }^{105}$ Castells éppen ezt fejtegeti A hálózati társadalom kialakulása c. könyvében. (Manuel Castells 2005)

106 Massey 1994, in. Jackson 2006

${ }^{107}$ Jackson az információs technológia távolságot legyürő erejének bemutatására a GA az ázsiai cunami katasztrófája utáni azonnali reakcióját mutatja be, ahogyan az 2005 karácsony másnapján reagált. Amikor januárban visszatértek a gyerekek az iskolákba, egy angliai tanárok által összeállított és összegyüjtött fantasztikus oktatási anyag várta őket arról, hogyan tudnak segíteni a csapást átélő embereknek, benne a környezeti katasztrófa fizikai okairól és rengeteg információval a katasztrófa emberi, társadalmi és politikai következményeiről. Mindez demonstrálhatja azt, hogy képesek vagyunk a technológiát és az interperszonális kapcsolatok hálózatát felhasználni, hogy akár nagy távolságokban zajló eseményekre is azonnal reagáljunk. A katasztrófát követő hetek egyértelmüen bebizonyították, hogy ezek a helyek a legelszántabb, segítőkész eröfeszítések ellenére is fizikailag megközelíthetetlenek maradnak.

${ }^{108}$ Magyar Virtuális Enciklopédia - http://www.enc.hu/1enciklopedia/fogalmi/filoz/informacio.htm

${ }^{109}$ A korszakalkotó évtized: Kisho Kurokawa, Tadao Umesao (1961), Jiro Kamishima (1964), Yujiro Hayashi (1969), Yoneji Masuda, Konichi Kohyma (1968), Yoneji Masuda (1971) - első angol nyelven megjelenő írás, majd az első információs társadalmat magyarázó szótár megjelenése 1971-ben. Lásd részletesen Z. Karvalics 2007., pp. 5-6.

${ }^{110}$ Érdemes azért tudni, hogy a „poszt-indusztriális társadalom” kifejezés jóval korábbi, és Ananda K. Coomaraswamy és Arthur J. Penty (1914), majd amerikai és francia társadalomtudományban (Daniel Bell, illetve Alain Touraine révén) éled újjá a 60-as évek végén. (Z. Karvalics 2007., p. 6.)

${ }^{111}$ Vö. Csatári (2003), Jakobi (2007), Kanalas (2003ab), Mészáros (2000, 2003), Nagy (2001, 2002, 2003, 2009), Sinka (2004, 2005, 2006a, 2008, 2009) és mások munkái.

${ }^{112}$ Megemlít egy hatodik csoportot is, a minőségi és mennyiségi diskurzus szintet is, amely talán segíthet pontosítani az első ötöt, de ezt most nem tárgyaljuk (pp. 21-28.). - (Theories of the Information Society, Routledge 1995, 2. kiadás 2002, 3. kiadás 2006)

${ }^{113}$ Egy az átlagtól harmónikusabb téma megközelítést olvashatunk Inkinen (2006): The Social Construction of the Urban Use of Information Technology c. tamperei esettanulmányában.

114 „A pénzpiaci forgalomnak már csak két-három százaléka szolgálja közvetlenül az ipar és a kereskedelem biztonságát, az összes többi a pénzpiaci spekuláció eszköze. A pénzpiacokon mozgó spekulációs tőke nem hoz létre új értéket (mint a termelőtőke), hanem a már meglévőt csoportosítja át.” (Lukács 2003, p. 41.)

${ }^{115}$ Gill Valentine and Stuart Aitken (2006, p. 332.): Contested geographies: culture wars, personal clashes and joining debate c. cikkében például hosszasan értekezik Mei-Po Kwan feminista geográfiájáról.

${ }^{116}$ Brants el al., 1996, in. Mészáros 2003, p. 121.

117 Jellemzően ide sorolják a zöldeket is a kutatók.

118 „A popular idea here is that the electronic highways result in a new emphasis on the flow of information (Castells, 1996), something which leads to a radical revision of time/space relations. In a 'network society' constraints of the clock and of distance have been radically relieved, the corporations and even the individual being capable of managing their affairs effectively on a global scale.” (Webster 2002, p. 17.) 
${ }^{119}$ Az információs társadalom terminusa a kora nyolcvanas évekre tehető, és körülbelül a hetvenes évek elejétől már használatos az információ kora kifejezés. A különféle kontextusból kiemelkedő, előbukkanó kísérletek próbálkoztak a megfelelő kifejezés megtalálásával, amely képes lehet visszaadni az ötvenes évektől érezhető társadalmi változásokat. Az információs társadalom fogalmának alapvetően két kiemelkedően fontos oldala a gazdasági és a kulturális. A gazdaságit elsősorban az információ árucikké válása (immaterializálódása) emeli ki, míg a kulturális jelleg ,,az anyagi fogyasztás csökkenése mellett megjelenő humán intellektuális kreativitás általános virágzása” jelenti (Masuda 1980, p. 3., in. Kellerman 2002b, p. 10.), ami egyben a társadalom kulturális identitásának keresésével párosul. Az információs társadalom két legfontosabb vezérlő folyamata a termelés és a fogyasztás. A termelés jellegzetessége lesz, hogy nem minden termék kerül „legyártásra” vagyis nem lesz anyagi vetülete, mint például a társadalomra jellemző infokommunikációs technológiai eszközök materializálhatók, a hozzájuk „gyártott” szoftverek, a rajtuk áramló adat és információ áru közvetlenül nem. A termelési folyamat legfontosabb termékei tehát: az IT hardver eszközök, a szoftverek, és nem utolsó sorban az információ maga, különösen az elektronikus, mint például az internet oldalak, televízió programok, filmek. Az eszközök széleskörü adoptációja három értelmezési keretet határozhat meg történetileg az információs társadalom fejlődése tekintetében: az első az információ-gazdag, a második az információ-alapú, és a harmadik az információ-domináns társadalmi keretét, ahogy azt Kellerman ábráján láthatjuk is. Az információs társadalom úm. inkubációs szakasza főként az USA területére esik, magában foglalva az ehhez szükséges legfontosabb társadalmi elemeket: az ipari társadalmat, a kapitalizmust, a hidegháborút, és a kultúrát mint információt. (Kellerman 2002b, p. 11.)

${ }^{120}$ Az információs társadalom kialakulásához (és az információ technológia elöretöréséhez) vezető folyamatok közül az egyik az információ (mint termék) folyamatos meghatározó erővé válása az amerikai társadalomban. Kellerman ennek vizsgálatakor négy fontos dimenziót különített el (2002b, pp. 9-15.): (1) az első dimenzió, amely meghatározta az információs társadalom és technológia előbukkanását a rohamtempóban fejlődésnek induló információ technológiai fejlesztések, amelyek egyre több szakképzett munkást (itt humánerőforrást értünk alatta) igényeltek. (2) A második az épp a születendő információ technológia lesz, amely közvetlen kapcsolatot biztosít (igaz egy zárt struktúrát generálva) a különböző típusú termelési folyamatok között, és egyes esetekben, az információ és a tudás felváltja a munkát, lehetőséget biztosítva arra, hogy az információ mint tôke, termelési tényezővé váljon. A kapitalizmus lesz tehát az egyik legfontosabb dimenzió, hiszen lényegébe „privatizálta az információt”. (Schiller 1981, Schement 1989, in. Kellerman 2002b, p. 12.). (3) A harmadik dimenzió egyértelműen a hidegháború volt. A hadiipari fejlesztések egyes elemei (például a Pentagon által megrendelt ARPANET, az első internet hálózat, e-mail, nagy hibatürő hálózatok stb.) fokozatosan átszivárogtak a közösségi szektorba, termékké váltak, míg a hidegháború másik oldalán álló („harcoló”) országoknál megmaradtak katonai alkalmazásnak, köszönhetően a diktatúrák logikájának. A (4) negyedik legfontosabb dimenzió a kulturális aktivitás fejlettsége a társadalmakban, ami igényel egy állandó és gazdag írásbeli és szóbeli közvetítést (publikációs aktivitás), amely régebben a mennyiség, a forma, idő és távolság kényszere alatt állt.

${ }^{121}$ „Information production, transmission and use has become a leading if not the leading economic and social activity, both as a product in itself and as a service leading to the production or consumption of material products. As such, three additional characteristics have been added to information society: information becoming a major product, information media beginning to fuse into each other, and information becoming a culture. Information has increasingly become a commodity in its own right.” (Kellerman 2002b, p. 14.)

${ }^{122}$ „Liberalization trends in the provision of information services to households, as well as technological advances, have brought about early signs of possible fusions among different forms of information, their transmission and use. Thus it has become possible, for example, to use the computer also as a telephone, fax and $\mathrm{TV}$, and receive several of these services from a single service provider. This fusion may possibly mature into a single appliance for information consumption and production, as well as so-called public networks of data and software (Halal 1993, Kellerman 1997).” (Kellerman 2002b, pp. 14-15.)

${ }^{123}$ „Cultural battles are the power battles of the Information Age. They are primarily fought in and by the media, but the media are not the power-holders. Power, as the capacity to impose behavior, lies in the networks of information exchange and symbol manipulation, which relate social actors, institutions, and cultural movements, through icons, spokespersons, and intellectual amplifiers. Culture as the source of power, and power as the source of capital, underlie the new social hierarchy of the Information Age." (Castells 1998, p. 348, in. Kellerman 2002b, p. 15.).

${ }^{124}$ Mark Granovetter szociológus (1973), sok viszontagságot megélt cikkét 1973-ban publikálta A gyenge kapcsolatok ereje címmel az American Journal of Sociology-ban. Granovetter az álláskeresők hálózatát vizsgálata Boston elővárosában, Newtonban. Lényegében ismertségi hálózatokat vizsgált és azt térképezte fel, milyen csoportok léteznek a területen és azok hogyan kapcsolódnak, ki-kit ismer. Kutatásában arra figyelt fel, hogy az álláskeresésnél nem a barát segített, hanem egy ismerös. Egy laza kapcsolat, egy ún. gyenge kapcsolat 
biztosított, ha formálisnak is tünt, olyan információs kapu, amelynek segítségével az álláskereső végül álláshoz jutott. Véleménye szerint a társadalom kapcsolatokban gazdag kis csoportokra tagolódik, csak néhány külső kapocs köti ezeket egybe. Vegyük is észre, mennyire rímel mindez Wiener kibernetikával kaocsolatos érvelésével! Granovetter érvelése szerint társadalmainkban sok teljes gráfot találunk, ahol a pici csoportokban mindenki mindenkivel össze van kötve, s a legkisebb eleme körülbelül a család szintje, s ezeket a kis csoportokat kötik össze laza kapcsok a többivel. Az elmélet lényege: a közeli barátok mindenkit ismernek, minket is, így ugyanazon ismeretanyagot használjuk fel a környezetünk észlelésekor (nem csak földrajzi információk esetében is) és ennek alapján hozunk döntéseket. Ahhoz, hogy sikert érjünk el, és a szükséges információkat be tudjuk szerezni, a laza kapcsolatokat kell mozgósítani, más csoportok információforrásait kell felhasználni, asszimilálni kell az észlelt információt. - Fontos, hogy egy véletlen hálózatban nem létezne baráti kör, mert mindenki mindenkihez véletlenül kapcsolódna, mint például az Erdős-Rényi-féle világ társadalmában (Az Erdős-Rényiféle modell egy véletlen világ modell, benne kis távolságokkal összekapcsolt hálózat, de baráti kör nélkül) a két barát ismertsége annyira esélyes, mint a világ másik pontján élő emberé. Ezen egy másik model, az erős kapcsolatok modellje sem segít, amely szabályos rácsmodellt képzel el, és mindenki mindenkivel kapcsolódhat. Granovetter gyenge kapcsolatokkal átszőtt társadalma, egy teljesen összeszőtt csoportok töredezett hálója, átmenet a véletlen és az erős kapcsolat között, és sikerre viszi a gyenge kapcsolatokon keresztül az információk átadását. - Lásd erről részletesebben Barabási 2003, pp. 61-77., illetve Csermely2005, pp. 103-120, pp. 237-245.

${ }^{125}$ Itt részletesen nem foglalkozok Robert David Sack kapcsolódó elméleteivel, bár később néhány munkájára hivatkozni fogok. (Sack 1980, in. Mészáros 2003, p. 31.)

${ }^{126}$ Léteznek további, matematikai modelleken alapuló tértípusok is, mint a diszkrét vagy fraktális terek modelljei. A fraktális terek folytonos, nem lineáris entitással leírható térbeli alakzatok, bonyolult és szabálytalan formák modellezésére használhatók, mint például a természetben található formák leírására. A diszkrét terek ezzel szemben lineáris entitással rendelkező folyamat modellezésében használatos. A diszkrét térmodellel ún. celluláris automatákat írnak le, amelyek dinamikus rendszerek, térben és időben diszkrétek, azonosan müködö szabályos rácsok, melyek karakterét lokális interakciók határozzák meg. (Coulesis 1995, pp. 218-219., Mészáros 2003, pp. 31-32.) Lásd még Michael Batty (1997): Cellular automata and urban form: A primer, Journal of the American Planning Association; Spring97, Vol. 63 Issue 2, pp. 266-275.

${ }^{127}$ Lásd még például a telephely elméleteket (Ricardo, von Thünen, Weber), a gazdasági körzetek elméletét (Krajkó) vagy a térbeli parciális egyensúly modelleket kutatókat (Lösh, Smith, Malthus, Christaller, Enyedi, Rechnitzer, Nemes-Nagy és sokan mások), akik a gazdaság vagy a népesedés szempontjából közelítettek a tér megragadható értelmezési formáihoz.

${ }^{128}$ Sack 1980, in. Coulesis 1995, p. 229., de lásd még Sack (2001a, 2001b) későbbi munkáit is.

${ }^{129}$ A szofisztikált kifejezés értelmezése a fenti gondolatmenet szempontjából: (pozitív jelentéstartalommal) kifinomult, igényes, müvelt, elegáns, bölcsességgel, tapasztalattal megalkotott, kidolgozott, profi, nem laikus; A negatív értelmezése, miszerint valami nem alkalmas hétköznapi, gyakorlatias használatra, ebben az összefüggésben nem releváns.

${ }^{130}$ Nem árt azonban számon tartani, hogy a kibernetika fejlődésével egyre sikeresebb kibernetikus organizmusok kifejlesztésén dolgoznak a tudósok. Ezek többsége még vagy egyszerü robottechnológia, vagy az orvoslás területén felhasznált, részben kibernetizált organikus egység, pl. idegpályákhoz kapcsolt müvégtag. - A kiborgok tökéletesedéséig, azonban még jobb esetben is az út elején vagyunk. Az első lépéseket azonban - mármár a sci-fi határát súrolva - önmagunk evolúciójában kell keresnünk. A humán evolúció, és a dolgozat konkrét témáját tekintve a földrajzi környezet észlelésének mechanizmusa is egy újabb evolúciós lépcsőre vár, vagy ha bátrabban akarunk fogalmazni, most készül egyik lábával fellépni arra a fokra, amely az említett kibernetikai forradalom eredményeképp várhatóan be fog következni. Az ember, mint humán entitás tapasztalati terének észlelése egyre erősebb függőséget mutat a technológia irányába, $\mathrm{s}$ aki nem rendelkezik a szükséges attribútumokkal (ezek egy csoportját például egyszerúen digitális írástudásként szokás aposztrofálni) annak $a z$ információs társadalom tere láthatatlan marad, s csak a fizikai teret, illetve a közvetlenül erre épülö térformációkat lesz képes észlelni. Lásd még ehhez A kognitív geográfia és A konnektivizmus földrajza c. fejezeteket.

${ }^{131}$ Jackson (2006) Thinking Geographically c. cikkében is találunk erre vonatkozó utalásokat.

${ }^{132}$ Saim Muhammad ezt a térkonstrukciót hibrid térnek nevezi (hybrid space). Lásd még Saim Muhammad (2006): New Meanings and Measures of accessibility in the Age of Information Technologies, Networks and Communication Studies, NETCOM, Vol. 20, No. 1-2, 2006, pp. 69-90. Lásd még itt Maria Paradiso (2003): Geography of the information society: A new culture of hybrid space? c. dolgozatát.

${ }^{133}$ Harvey 1993, p. 4., in. Kellerman 2006, p. 129.

${ }^{134}$ Kellerman eredeti forrása: Castells 2000, p. 453. 
${ }^{135}$ David Harvey (1990): A posztmodernitás állapota (The Condition of Postmodernity), Blackwell Oxford

${ }^{136}$ Castells addig megy, hogy a társadalmi folyamatok által eredményezett folyamatok térbeli hatásának lecsapódását, mint örökölt térbeli struktúrát jelöli meg, ami hatással van az épített környezetre, tovább örökítve azt. Mindez egy múltbéli térstruktúra társadalmi tovább örökítése, annyira, hogy a tér a megszilárdult idő. Castells ezen kijelentése Mcluhan Guttenberg-galaxisának egyik felvetésével is összecseng, amikor Mcluhan a tipográfiai térről beszél, megemlítve annak minden esetben múltban gyökerező eredetét. Arra utalva ugyanis, hogy a tipográfiai tér mindig egy - nyelvészek szerint legalább egy emberöltővel - korábbi időszak térfelfogását és tér narrációját tükrözi vissza. Amikor beszélünk, cselekszünk, észlelünk a hétköznapokban élünk, amikor írunk és szöveget fogalmazunk, a szüleink, nagyszüleink látásmódját használjuk az események narratívájához. A tipográfiai tér mindig archaikus.

${ }^{137}$ Ahogy Buttimer és Cséfalvay elméleti megközelítésénél már láthattuk a korábbi fejezetekben.

${ }^{138}$ Agnew és Duncan 1989, in. Kellerman 2006, p. 129.

${ }^{139}$ Lényegében ez az egyedi azonosítója, az identifikációjának egyedi leírása, az ún. geo kód.

${ }^{140}$ Adams, az időföldrajzi modellek elemzésénél, cikkében kifejti, hogy a tér szövetében az egyes emberek felcserélhetök, áthelyezhető elemként viselkednek, lényegében az embereket pont entitásokhoz hasonlíthatjuk. Mindemellett Torsten Hägerstradra hivatkozva megjegyzi, hogy az egyéni emberi létezés (individual human being) azt is jelenti, hogy az egyénnek speciális szükségletekkel és felelösségvállalással rendelkezik, és amely nem egyértelmủen egy hely lesz a térben, hanem kulturális és gazdasági hatás alatt formálódó egyéni magatartásforma. (Adams 1995, p. 270.)

${ }^{141}$ „Traditionally, place is an interweaving of communication and action. [...] Geographers have argued that place is defined by the communication acts that structure both personal activities and collective social processes (Tuan 1991; Pred 1990). Other scholars have shown that various modes of communication-in- place reinforce and reify the connection between place and social situation.” (Adams 1998, p. 94., vö. Kellerman 2006, p. 129130.)

${ }^{142}$ Lásd WIP felmérések kutatási jelentéseit, illetve vö. Sinka 2005, 2007.

${ }^{143}$ A „kommunikáció és cselekvés” fogalompár valós és virtuális teret összekötő legszemléletesebb példája ma az e-learning alkalmazások térnyerése. Részletesebben lásd még erről A konnektivizmus földrajza c. fejezetet.

${ }^{144}$ A szimbiotikus mutualizmus kifejezést azért használom erre a folyamatra, mert: (1) A szimbiózis egyfajta élettani, a létezéshez kötődő kölcsönös együttélést kíván kifejezni, egy életközösséget, amely ebben a kontextusban akár fizikai, akár virtuális is lehet. A biológiai utalás az életközösségek és társadalmak evolúciós folyamataira is vonatkozik, mert hipotézisem szerint nem csak a fizikai térben, de a virtuális terekben is zajlik egyfajta evolúció, amely részben technológiai, részben a benne „élő” egyéni entitások, csoportok és társadalmi rétegek között zajlik. Az evolúciós kihívás az, ki tud alkalmazkodni a technológia változásaihoz, illetve ki képes, nem csak létrehozni, de müködtetni/életben is tartani a virtuális identitását; (2) A mutualizmus, számomra ebben az összetételben azt a (kulturális és gazdasági alapú) szociális irányelvet próbálja megragadni, amely a kölcsönösség elvén egymás szükségleteinek kielégítését célozza meg. A kettő együtt a fizikai és virtuális térben történő létezésnek mára elválaszthatatlan értelmezési kerete.

${ }^{145}$ Léteznek modern várostervezéssel és területfejlesztéssel foglalkozó munkák is, amelyek az információs technológia által generált változások outsider megközelítését naprakészen tárgyalják. Ilyen munka például Corey és Wilson (2006): Urban and regional technology planning: planning practice in the global knowledge economy c. munkája, amely nem valamiféle manuálé akar lenni a várostervezés problémáihoz, csupán egy új metódust kínál a technológia és annak szociális hatásainak együttes kezelésére.

${ }^{146}$ Kultúrától (és persze a témától) függően két ember között, hangátvitel útján történő információcsere, vagyis például egy beszélgetés természetes távolsága hagyományos keretek között 1-8 méterig terjedhet, az előbbi az ázsiai, arab, míg utóbbi inkább az észak-európai népekre jellemző. E. T. Hall könyvében nem csak a kulturális különbözöségekre, de a nyelvi és térhasználati szokásokra vonatkozóan is több különbözö ún. távolságosztályt vezet be, illetve ezekhez kapcsolja a proxemikai percepció kölcsönhatásait is. (1996, pp. 151-166.) Négy távolságosztályából az alsók megfeleltethetők Wiener alsóbb csoportszintjeinek, illetve Kellerman alsó két értelmezési rétegének. Ezek fölött a megfeleltetés ugyan nem paralel, azonban minden esetben alapvetően a növekedési dinamikával, az igényelt tér nagyságával és a belső kommunikáció homeosztatikus szerepének hangsúlyozásával jellemezhető osztályozásokkal találkozhatunk minden esetben.

${ }^{147}$ A kibertér aspektusában készíthető tipológiai összefoglalás a távolságmérés, a szomszédság, a területiség (fedvények) tekintetében, de ezek jelen gondolatmenetben nem relevánsak.

${ }^{148}$ A proxemika a kommunikáció és a hétköznapi tevékenységek során a személyek között betartott távolság kutatásával foglalkozik. A térhasználat ilyen módú vizsgálatára Hall tett javaslatot még a hatvanas években. 
149 „Földünk lakossága napjainkban a városokba özönlik, amelyek zsúfoltsága lassanként a hidrogénbombánál is veszélyesebb, hiszen a mindent elpusztító „kiborulás” („,szink”) tüneteit fogja kiváltani. Az ember az ezek során kibontakozó láncreakciókról gyakorlatilag alig tud valamit, nem ismeri ezek kulturális atomjainak a szerkezetét. Tudjuk, mi történik, ha egy állatközösség túlnépesedik, illetve idegen biotópba kényszerül; ha az állatokon megfigyelt jelenség az emberre is érvényes, iszonyú következményekkel fog járni a városainkban máris érzékelhetö „,szink”. Az etológiai és összehasonlító proxemikai tanulmányokból kiolvashatjuk a figyelmeztetést: a vidéki lakosság városba özönlése veszélyes helyzetet teremt. Ezekről az emberekről nemcsak gazdasági vonatkozásban kell gondoskodni, hanem egész életmódjukat is újjá kell szervezni. További bonyodalmakat okoznak a szokatlan kommunikációs rendszerek, a megfelelö terek, valamint az aktív, egyre fokozódó „kiborulás” patológiás tünetei.” (E. T. Hall 1996, p. 207.)

${ }^{150}$ Az angol „szink” (sink) szó szennyvízlefolyót, szemétgödröt jelent. John Calhoun a szink-viselkedés kifejezést alkotta a rockwille-i patkányok többségénél fellépő viselkedésbeli eltorzulásokra, köznapi szóval a kiborulásra. A jelenség azért kapta ezt az erős jelzőt, mert a viselkedészavar további kóros elváltozásokat (daganatos betegségeket) okozott. (Hall 1996, p. 43.) A kísérletet lásd részletesebben Hall könyvének 39-51 oldalán, vagy itt: http://eprints.lse.ac.uk/22514/1/2308Ramadams.pdf; utolsó elérés: 2010.08.20.

${ }^{151}$ Az információs társadalomhoz kötődő kutatások gyakran foglalkoznak azzal a problémakörrel, amely a társadalmi kirekesztés miatti virtuális élettér és identitás alternatíváit vizsgálja. A valós társadalmi közegben önmagukat jelentéktelennek, elhanyagoltnak érző emberek gyakran olyan virtuális identitás kialakítására törekednek, amely által képesek kompenzálni mindazt, amit normál körülmények között nem képesek elérni. Ez esetben nem kizárólag az anyagi javakra gondolok, hanem azokra a vizuális (tér-) élményekre, amelyek környezetükben elérhetetlenek. Jellemzően erre épül a tömeg média által közvetített, luxus körülményeket ábrázoló dél-amerikai szappanoperák logikája is, azok ugyanis soha nem játszódnak a gettókban, arra senki nem kíváncsi.

${ }^{152}$ Hasonló attitűdváltásra kényszerül az is, akinek munka vagy tanulás miatt a fizikai biotóp mellett egy virtuális biotópban is otthon kell éreznie magát. Az e-learning használathoz kötődő vizsgálataim mutatják, hogy a fizikai és virtuális térben történő navigálás, a két eltérő természetủ tértípus sokaknak kihívást jelent, jóval nagyobbat, mint például magának a diplomához szükséges szakismeretnek az elsajátítása. (Sinka 2007a) A fizikai tér jellemzően motorikus (kognitív percepció) és a virtuális tér döntően elmebeli komputációs (mentális percepció) jellege a Hall által említett biotóp váltás tipikus esetét eredményezi. Akinél nem megy végbe az attitüdváltás, az hajlik a „szink” felé, önpusztító magatartást tanúsít, ellenáll és minden erejével szabadulni akar.

${ }^{153} \mathrm{Az}$ idézetben leírt folyamat, és az általa kiváltott stressz hatás jól szemlélteti azt a felelősséget, amellyel a geográfusoknak a térben zajló folyamatokat vizsgálnia, értelmeznie és publikálnia kell. A vizsgálatokat interdiszciplinaritásnak, az értelmezést relációs gondolkodásnak, a publikációt céltudatos (a célközönség értelmezési szintjén befogadható) információkészlettel rendelkező dialektikus narrációnak kell jellemeznie.

${ }^{154}$ Az idézet abból a szempontból is érdekes, mert Hall könyvének eredeti kiadása 1966-os, ami egyben azt is jelzi, hogy a klasszikus indusztriális társadalmi rend felbomló félben van, jön a posztindusztriális korszak. Míg az indusztriális rendszer mindent az ipari termelés alá rendelt, a posztindusztriális új munkamegosztási formákat keres magának, felborítja a társadalmi munkamegosztás hagyományos formáit és újra strukturálja a telephelyelméleteket ahol csak lehet. Egészen biztos, hogy Hall nem ezt látta, hanem a háború utáni élénkülő konjunktúrát, a rurális terek (beleértve a déli feketék északra vándorlását, vagy az európai bevándorlók) új exodus-át a nyugati városok irányába, aminek eredményeképpen kialakuló városi stressz kezelésére sem a városok vezetése, sem a településfejlesztés nem volt felkészülve. A háború utáni Magyarországon magunk is megélhettük az ipari tengely vonzása miatt „elnéptelenedő” vidéki térségek problémáját, amit az ipar technológiai megoldásokkal (korszerübb mezögazdasági gépek, tömegközlekedés fejlesztése) igyekezett kompenzálni. Amit azonban nem tudott: a teret visszaadni azoknak, akiktől elvette. A vidéki rurális térségekből a városokba kerülő értelmiségiekkel beszélgetve ma is tapasztalom, hogy a jobb életkörülmények ellenére a legtöbben a tér hiányára panaszkodnak. Ha közelebbröl érdeklődöm, hogy mit értenek ez alatt, akkor egyszerre jelenik meg a látótér (ami alatt lakóteret és mozgásteret együttesen értenek) és az idő hiányának érzete. A tér számukra egybeforr az idő fogalmával. „A faluban volt idő mindenre, a városban csak rohanunk.” - válaszolják. Egy svéd kutatópár (Peter Dobers és Anette Hallin) érintette ezt a problémát a svéd nagyvárosokba érkező vidéki lakossággal kapcsolatban. A dolgozatot eredetileg The Big Picture and the Small Talk címmel hallhattam az IGU Digital Communities 2005 konferencián Nápolyban, majd később némileg átdolgozva, Slipping into Darkness: A Study of the Role of ICTs in the Making of Stockholm's Image címmel jelent meg a Journal of Urban Technology 2006. decemberi számában. A dolgozat Stockholm 2004-ben publikált és 2034-ig érvényes fejlesztési tervének vízióját vetette össze a város lakóival történő interjúkkal. 
${ }^{155}$ Hangsúlyoznom kell, hogy ebben a részben a hálózat fogalma alatt jellemzően a lineáris infrastruktúra infokommunikációs hálózatát értem, s ahol szükséges, azt megkülönböztetem a szociális/közösségi vagy társadalmi, illetve egyéb hálózatoktól.

${ }^{156}$ Az összekapcsolódást és átjárhatóságot biztosító interfész specifikációi között két nagy csoportot különböztethetünk meg: (1) a technológiai, (2) a humán interfész. (1) A technológiai interfészek mindazok a szoftveres és hardveres eszközöknek az együttese, amely a hálózati infrastruktúrát logikai és fizikai értelemben felépítik. Természetesen a hagyományos hardver/szoftver elembontást is elvégezhetjük, és további részletesebb interfész típusokat is meghatározhatunk. (2) A humán interfész kérdése már kényesebb terület, de alapvetően olyan kognitív szenzoros képességet értek alatta, amely segítségével a humán entitás képes nem csak direkt hatásra, hanem benső attitüd által is létrehozni és életben tartani saját valós/virtuális identitáspárját. Fontos az életben tartartás, a kreáció önmagában nem elegendő, folyamatos interakció szükséges, mert ez az interakció hozza létre, konstruálja meg az entitás terét, a miliőt, amelyben (anyagi struktúrák nélküli) aktivitása zajlik.

${ }^{157}$ Felvetődhet ugyan a kérdés, hogy hol a határ és az érintkezési pont, valóság és virtuális világ között, mert a valós tér is folyton változik, a virtuális tér pedig hétköznapi értelemben abszolút immateriális fogalom. Itt azonban nem egy simulacrumról, egy másolatról, csalóka látszatról van szó. Nem a valós leképezését keressük, hanem az átjárót, a kaput térben, időben, dimenzionálisan, testben és elmében, melyet Æsahcettr metsz ki a számunkra.

${ }^{158}$ A dolgozat szempontjából a földrajzilag meghatározható entitások lényege a létük, a létezés (formától függetlenül) a tér bármely dimenziójában. Sokféle entitás csoport alakítható ki, gyakorlatilag végtelen csoportosítás áll a rendelkezésünkre a földfelszínen és a virtuális térben egyaránt. A témakör tárgyalása szempontjából egy egyszerü megközelítéssel entitások halmaza alakítható ki a térbeli információt hordozó, továbbító és befogadó entitásokból. Mindamellett ezek számos vegyes halmaza is képezhető az elemekből. A fizikai környezet észlelése például jellemzően a hordozó entitások által közvetített érzékelésen keresztül történik, amelybőll saját tapasztalati terünkröl alkotott mentális úm. tér-képünket (térről alkotott szubjektív leképezésünket) kialakíthatjuk.

${ }^{159}$ A legjobb esetben potenciális csomópontként (network node) aposztrofálható, rosszabb esetben (logikai és fizikai értelemben) inkompatibilis végpontokká válnak, amelyek a szükséges interfész nélkül nem illeszthetők ebbe a struktúrába. Ez a megállapítás mindkét hálózati alaptípusra érvényes: a fizikaira és a szociális hálózatokra egyaránt.

160 „If, as structurationists argue, place is process (Pred 1984b), then process can also be place; the implication of this processual similarity is that place indicates a process that might be divorced from material structure and location.” (Adams 1998, p. 94.)

${ }^{161}$ A gondolatmenet tovább is fejthető, és ahogy egy geológiai fáciest jellemez a benne lévő kőzetek, üledékrétegek és ősmaradványok térbeli (vertikális, horizontális) elrendezettsége, úgy a technológia adott szintjén, az időben lezajló folyamatokból „,megszilárdult térben” (lásd korábban Castells kapcsolódó idézetét) fellelhető eszközök az adott társadalom információközlő és kommunikációtechnikai lenyomatai. A technológiai fossziliák egy-egy csoportja, Wiener már említett gondolatához kapcsolódva, a társadalmi homeosztázist egykor fenntartó eszközöknek felelnek meg.

${ }^{162}$ Kiváló példa erre, amikor a relief, a talajmechanika, a sủrủ vegetáció vagy védett természeti értékek határozzák meg az IKT alkalmazások kiválasztását, és például a domborzat vagy a kemény kőzet miatt nem fektethető alépítményes hálózat, ilyenkor oszlopokra helyezik a hálózati eszközöket vagy vezeték nélkülit építenek ki. Más esetben a vezeték nélküli (wireless) hálózat helyett kell jóval költségesebb alépítményt vagy légvezetéket választani, mert a sủrủ vegetáció évszakonkénti váltakozása (lombhullás, tủlevelek stb.) miatt a rádiós rendszerek üzemeltetése nem nyújt stabil szolgáltatást.

${ }^{163}$ Erre szemléletes példa, hogy Magyarország egyes területein (kiemelten alacsony népsürüségű, rurális területeket mind az alföldön és a hegy-dombvidékeken) elérhetetlen a szélessávú hozzáférés, néhol maga az internet csatlakozás is problémás. Az okot a profit oldalról, a területi diszperzió miatti alacsony bevételekben kell keresni. Az észt, finn példától, miszerint „az internet társadalmi alapjog”, még igen messze állunk.

${ }^{164}$ Például: technikai/fizikai/anyagi tér, társadalmi tér, szubjektív/filozófiai/pszichikai tér, gazdasági tér, kommunikációs tér, humán erőforrás tér és például a tipográfiai tér, vagy az egyik legújabb megközelítésként a konnektivista tér, amely számos említett tértípust ötvözve inkább egy tematikus „tércsoport” összefoglaló neve.

${ }^{165}$ Az IGU Geography of the Global Information Society Commission tagjaként közvetlen tapasztalatom van ennek a paradigmaváltásnak a megszületésében (2005-től résztvevő, 2007-től bizottsági tag). 
${ }^{166}$ Lásd ehhez korábban A tér és hely narratívái, tipológiai kísérletek c. fejezetet, és vö. Buttimer (1990, 2000) és Cséfalvay (1990) említett munkáival, illetve Johansson (2000) nézőpont aspektusaival, és Kellerman (2007) kibertér tipológiai osztályaival.

167 Troels Degn Johansson (2000): Visualization in Cyber-Geography - Reconsidering cartography's concept of visualization in current usercentric cybergeographic cosmologies, CASA Working Paper 17, forrás: http://www.casa.ucl.ac.uk/publications/workingPaperDetail.asp?ID=17; utolsó elérés: 2010.08.20.

168 „The idea of approaching such a complexity of data and to organize and analyze it according to a given hypothesis of how the geographical world is like rather than to traditional perceptions thus leads Goodchild to talk about a "second age of geographical exploration"; a kind of exploration which is obviously different to the classical cartographic unveiling and mapping of “terra incognito”.” (Troels Degn Johanson 2000, p. 5.)

${ }^{169}$ Kevin Kelly (1994): Out of control: the rise of neo-biological civilization, Addison-Wesley Publishing Co., 1994., in. Batty 1997.

${ }^{170}$ Howard Rheingold (1993): The virtual community: homesteading on the electronic frontier, MIT Press 1993., in. Batty 1997.

171 „In the 1990s, this network paradigm is now writ large, '...the symbol of science for the next century...' as Kelly ${ }^{171}$ persuasively argues. Computation can take place between any place and any other, software and data can be similarly remote, and processing can take place anywhere and everywhere. The best example of this phenomena is the rise of the World Wide Web, the paradigm of late $20^{\text {th }}$ century computing, which is in many senses the visual interface to the net; to e-mail, the downloading and use of software and data; to bulletin boards and newsgroups, and all the other information sources that are now linked together in the anarchic organization of the net. The kind of geography that is emerging in this cyberspace is one that in its clearest form, mirrors local communities or interest groups linked through some common purpose as virtual communities, virtual self-help groups, groups that talk and act across the net, informally, expediently, embodied in net-action; as ephemeral as 'internet relay chat' to formal research groups such as those based on professional communication amongst peers involving frequently asked questions, preprints of articles, announcements of meetings in cyberspace as well as real place. These kinds of geography are being popularly discussed, explored and charted ${ }^{171}$ but the geography is simple and the spaces only identified superficially and informally to date.” (Batty 1997, p. 344.)

${ }^{172}$ A jövőt azonban tisztán látta, és feltételezhető, hogy az idézett cikk megírása elött már olvasott Don Tapscott (1993) New Paradigm néven futó kutatásáról. Az azonban biztos, hogy 2009-ben már hivatkozik Tapscott Wikinomics (magyarul Wikinómia) c. könyvére (2006) a NeoGeography and Web 2.0: concepts, tools and applications c. tanulmányban, amelyben társzerzőként szerepel.

${ }^{173}$ Batty eredeti felosztása: „place/space: the original domain of geography abstracting place into space using traditional methods; cspace: abstractions of space into c(omputer)space, inside computers and their networks; cyberspace: new spaces that emerge from cspace through using computers to communicate; and cyberplace: the impact of the infrastructure of cyberspace on the infrastructure of traditional place.” (Batty 1997, p. 340) Figyelemre méltó azonban, hogy egy évvel később már ő is finomabb osztályozással kísérletezik a virtuális városi környezetek modellezésénél. (Michael Batty et al. (1998): Modelling Virtual Urban Environments, forrás: http://www.casa.ucl.ac.uk/publications/workingPaperDetail.asp?ID=1; utolsó elérés: 2010.08.20.)

${ }^{174}$ William Gibson: Neurománc (eredeti nyelven Neuromancer), 1984.

${ }^{175}$ Kellerman által megjelölt források: Michael L. Benedikt (1991): “Cyberspace: Some Proposals,” in. M. Benedikt, ed., Cyberspace: First Steps (Cambridge, MIT Press 1991); Rob Kitchin (1998): Cyberspace: The World in the Wires (Chichester, John Wiley and Sons, 1998), p. 2.

176 „Artificial Reality: “Cyberspace is a globally networked, computer-sustained, computer-accessed, and computer-generated, multidimensional, artificial, or “virtual’ reality.” (Benedikt 1991, Kitchin 1998) ${ }^{176}$

${ }^{177}$ Michael Batty (1997): Virtual geography, Futures, Vol. 29, 1997, No. 4/5, pp. 337-352., az idézett rész: pp. 343-344.

178 „Interactivity Space: “Interactivity between remote computers defines cyberspace ... cyberspace is not necessarily imaginedspace - it is real enough in that it is the space set up by those who use remote computers to communicate.” (Batty 1997, pp. 334-344.) ${ }^{178}$

179 „Conceptual Space: “The conceptual spacewithin ICTs (information and communication technologies), rather than the technology itself.” (Dodge és Kitchnin 2001)

${ }^{180}$ M. Dodge (2001): Guest Editorial, Environment and Planning B: Planning and Design Vol. 28, pp. 1-2.

${ }^{181}$ R. Shields (2003): The Virtual, Routledge 2003., p. xv és p. 49. 
${ }^{182}$ M. Auge', Non-Places: Introduction to an Anthropology of Supermodernity, J. Howe, trans. (London: Verso, 2000).

${ }^{183}$ A szerepjátékokban rendszerint a teljes valós világ leképezése megtörténik. Az élet valamennyi területére létezik virtuális megoldás, mint például a Second Life - http://second-life.com/, a Twinity http://www.twinity.com/en, vagy a Visuland - http://visuland.com/. Ezek neve MMORPG - massively multiplayer online role playing game, vagyis online szerepjátékok, és általában megkülönböztetik őket az MMOG-októl, amelyek inkább többszereplős online játékok. Találunk erre a logikára épülő tematikus programokat is, mint például üzleti (Vastpark - http://www.vastpark.com/) vagy az egyedülállók társadalmi kapcsolatépítését támogató megoldásokat (OmniDate - http://www.omnidate.com) is, hogy csak napjaink néhány ismertebb alkalmazását említsem. Az ezekhez hasonló oldalak száma gyakorlatilag kimeríthetetlen. Ráadásul a mutual compatibility elvén már dolgoznak ezek kölcsönös átjárhatóbbá tételén is. A nemrég elkészült Strategy Analytics jelentésben, amely Market Forecasts for Virtual World Experiences néven jelent meg, a következö évtizedben a virtuális világok robbanásszerü növekedését jósolják. Forrás: http://www.strategyanalytics.com/default.aspx?mod=ReportAbstractViewer\&a0=3988; utolsó elérés: 2010.09.02. - Lásd még Rheingold (2000), in. Rethinking Virtual Communities c. fejezetet. (pp. 323-391.)

${ }^{184}$ Ide sorolja Kellerman a honlapokat, weboldalakat és egyéb web helyeket, a szörfölést, a kurzort, mint helyőrzőt és hely mutatót, és minden olyan virtuális eszközt, amely az elfogadott földrajzi térmetaforákkal operálva teszi lehetővé a fizikai térhez hasonló aktivitást és manipulációt.

${ }^{185}$ Donald G. Janelle (1973) ehhez hasonlóan ír cikkében: „Human extensibility is conceptually the reciprocal of time-space convergence. Instead of focusing on the improved abilities for movement over greater distances it may be more appropriate to consider the expansion of opportunities for human interaction. In a figurative sense, "as the world shrinks, man expands." For example, with communications advances, politicians may project their images and messages over territories of increasing size to larger numbers of people.” (Janelle 1973, p. 11.)

${ }^{186}$ „Az emberi szervezet csodálatos, rendkívüli múlttal rendelkezik. Leginkább az a tény különbözteti meg a többi élölénytöl, amit én a szervezet hatóképessége kiterjesztésének nevezek. [...] A számítógép például nem más, mint egy bizonyos agyrészlet hatásszférájának a kiterjesztése oly módon, mint ahogy a távbeszélő a hang hatókörét terjeszti ki, a kerék a lábakét. A nyelv a tapasztalást terjeszti ki időben és térben, míg az írás valójában a nyelv hatásképességének a kiterjesztése. [...] Weston la Barre antropológus kimutatta, hogy az ember az evolúciót saját testi síkjáról a hatóképessége kiterjesztésének a síkjára tette át, és ezzel hallatlanul felgyorsította az evolúciós folyamatot.” (E. T. Hall 1996, pp. 12-13.)

${ }^{187}$ A láthatatlan (látens, észrevétlen, diszfunkcionális) információs társadalom elmélete. (vö. például Pintér 2004, pp. 78-83., vagy Sinka 2006a, 2008)

${ }^{188}$ A két tér összevetésének általam is elfogadott, a szoros interdependencia miatti egymásba ágyazottságot tükröző kapcsolatrendszerét összefoglaló ábra (Kellerman 2002b, p. 38.) a következő fejezetben kerül elemzésre.

${ }^{189}$ A legegyszerübb példa talán a lakóhely - munkahely szétválasztása. Az emberek többsége nem szívesen keveri össze a két helyet, amelynek az oka jellemzően az, hogy más viselkedéstípust hordoznak a munkahelyükön, mint a család körében. Ha ez így van, ez eltérő, több-személyiségü, lokalitásfüggő identitásokat feltételez. Innen a többrétegủ identitás Kellerman által is (2002b, 2007) említett (helyhez, térbeli aktivitáshoz kapcsolt) fogalma.

${ }^{190}$ Érdemes megemlíteni egy pszichológiai munkát, amely kiváló olvasmány a témában: Foreman és Gilett (1998): A handbook of spatial research paradigms and methodologies, Psychology Press 1998.

${ }^{191}$ Adams cikkében az időföldrajzi elméletek kapcsán beszél az emberekről, mint pont-entitásokról. (Paul Channing Adams (1995): A Reconsideration of Personal Boundaries in Space-Time, Annals of the Association of American Geographers, Vol. 85, Issue 2, 1995. június, 267-285., p. 270.)

${ }^{192}$ A virtuális aktivitás akkor is fenn áll, ha a fizikai kiesik, vagy épp megváltozik, ezért ezeket a hagyományos tér-idő piramis helyett egy párhuzamos „,csatornában” (channel) lehet szemléletesen és értékelhető módon ábrázolni. Nehezíti a dolgot, hogy más kapcsolódási forma jön létre a vezetékes és a vezeték nélküli hálózat esetében, illetve a mobilitás hatására fedésbe is kerülhetnek a terek, vagy épp eltérő irányú mozgást is lehetővé tesznek. Nem a megközelítések bonyolultsága, inkább az ábrázolás és analízis nehézsége okozza a legtöbb problémát mind vertikális mind horizontális irányban. Szinkron és aszinkron terek keletkeznek, a celluláris bontás fizikai rétegét a mobil és internet hálózat adja, de az egyéni kapcsolat soha nem kapcsolódik egy rögzített lokációhoz. Hägerstrand koncepcióját a virtuális tér komponens analízisével is ki kell egészíteni. Lásd például Hongbo Yu (2006) és Shih-Lung Shaw $(2006,2008)$ ide vonatkozó munkáit. (Hongbo Yu és Shih-Lung Shaw (2008): Exploring potential human activities in physical and virtual spaces: A spatio-temporal GIS approach. International Journal of Geographic Information Science 22:409-30; vagy online forrásként itt: http://www2.geog.okstate.edu/users/HongboYu/NSF-Project-Website/default.htm; utolsó elérés: 2010.08.26.) 
${ }^{193}$ A Kondratyev-ciklusok egyes szakaszait sokat vizsgálták, vitatták és vitatják napjainkban is. Az egyes értelmezések magyarázatától és a ciklus szimmetrikus vagy aszimmetrikus eloszlásától eltekintve most csak annyit fogadjunk el, hogy létezik ciklikusság, amely történetesen Kondratyevnél, a bázisinnovációk elméleténél ez átlag 50 évet jelent. A technika megújulásának ciklusaira építve jött létre az „innovációcsaládok” elméletel, s Kondratyev úm. hosszú ciklusaira Schumpeter három, majd Mensch egy negyedik bázisinnovációs szakaszt is bevezetett, mely utóbbinak a kulminációját kb. az ezredfordulóra datálta. (Kehl - Sipos, 2007, pp. 252-254.) Az ötödik bázisinnovációs ciklushoz azonban még nem tudni pontosan mi lesz az innovációs start. Feltételezik, hogy egy technológiai konvergencia az ún. „NBIC (nano-bio-info-cogno szinergia, vagyis a nanotechnológia biológia - információ technológia - kognitív tudományok szinergiája várható) technológiák összeolvadását, és ebből következően egészen új technológiai területek megjelenését eredményezi majd.” (Kehl - Sipos, 2007, pp. 252-255.) Ennek megfelelően a még javában zajló ötödik Kondratyev-ciklust, az információtechnológiára épülő ciklust, egy hatodik fogja felváltani, amelyet Szalavetz (2006) is megemlít az általános célú technológiák között (general purpose technologies - GPT), és a nanotechnológiát jelöli meg, mint az információtechnológiához hasonló alaptechnikát. Ahogy Jovanovic és Rousseau (2005) írja cikkének bevezetőjében: „The term „generalpurpose technology" or GPT, has seen extensive use in recent treatments of the role of technology in economic growth, and is usually reserved for changes that transform both household life and the ways in which firms conduct business. Steam, electricity, internal combustion, and information technology (IT) are often classified as GPTs for this reason. They affected the whole economy.” A villamosítás teljes adoptációját követő IKT korszaka Szalavetz szerint még mindig intenzíven tart, emelkedő szakaszban van, melyet a felhasználók számának fokozatos növekedése is jelez. Egyetértve a gazdasági ciklusok és innovációk kutatóival, akik a szakasz gyorsulását feltételezve 2020 körülre datálják a fordulatot, vagyis egy új bázisinnováció megszületését, a jelenlegi végét még csak megjósolni sem lehet. Ennek okait abban a humán interfész nélküliségben látom, amelyről a későbbi fejezetekben részletesebben is szó lesz, és amely mintegy természetes (kognitív-evolúciós és tanulás-kompetencia alapú) gátja a technológiai forradalom globális adoptációjának, s aminek a társadalmigazdasági térben határozott leképeződései vannak.

${ }^{194}$ Lásd itt még Hronszky (2002): Kockázat és innováció, A technika fejlödése társadalmi kontextusban c. munkáját, különösen az innovációra vonatkozó részeket.

195 A digitális szakadék tényét természetesen nem szabad figyelmen kívül hagyni, és a klasszikus „észak-dél” és „kelet-nyugat” relációk problémáit sem, a gondolatmenet szempontjából azonban ezek kifejtése most nem releváns. Annyit azért érdemes rögzíteni, hogy az ember nem csak a fizikai teret alakítja át, hanem az általa létrehozott virtuálist is, amelyet ugyanúgy gyarmatosított, mint korábban a földrajzi felfedezések korában, és átültette mindazokat a negatív társadalmi sztereotípiákat is, amelyeket az abszolút térben már létrehozott. Ebbe a körbe tartozik például hozzáférés kérdése, a rendszergazdák moderátorok és irányítók hatalmi hierarchiája, de a nemi, faji, vallási stb. diszkriminációk is, miközben jogos elvárás lenne, hogy az új információs és kommunikációs technológiák csökkentsék a társadalmi kirekesztést. (Pintér 2004, p. 207.)

${ }^{196}$ Ez a tér abszolút értelemben a földfelszín alatti alépítményektől a geostacionárius pályán keringő müholdakon át a Viking (1975) és Mars Pathfinder (1996) szondákig és a Voyager ürszondákig (1977) terjed. Az utóbbiak az ember által épített legmesszebbre jutott eszközök, mert a Naprendszer határának is tekinthető helioszférán is túljutottak. A relatív (virtuális és közvetve mentális) térkompozíciók skálafüggetlen topológiáiban pedig az alkalmazott eszköz és a humán interfész kompetenciája (beleértve a tudás és jogosultságok kompetenciacsoportjait is) határozza meg a virtuális kvázi-plasztikus tér bejárható lokációit.

${ }^{197}$ A humán erőforrás és a humánerőforrás nem teljesen azonos fogalmak. Az alapvető különbséget a humán jelző szerepe, kapcsolódása határozza meg. Külön írva az ember, mint erőforrás, a tudás és információhordozó szubjektív attribútummal rendelkező entitás értelmezhető. A humánerőforrást, különösen az EU relációkban az angolszász irodalom egyértelmüen a munkaerővel azonosítja, a szakmai kompetenciát hordozó, vagyis szakképzett, munkaerő piaci szereplőt értik alatta. A dolgozatban magam is több értelemben fogom a fogalmat használni, és igyekszem egyértelmüen jelölni mikor melyik érvényes.

${ }^{198}$ A humán erőforrás értelmezési keretébe tartozó néhány fogalmi megközelítés: az információs társadalom polgára, a duális tér aktivizálója, entitás és hálózati csomópont, humán és hálózati interfész, a konnektivista paradigma célpontja és hordozója.

${ }^{199}$ Lásd Don Tapscott és Antony D. Williams Wikinómia c. könyvében Az új alexandriaiak c. fejezetet. (Tapscott - Williams 2007, pp. 161-192.)

${ }^{200}$ Már viszonylag hamar megjelennek a téma iránt érdeklődő geográfusok munkái. Az egyik ilyen összefoglaló munka: David Mark et al. (1999): Cognitive models of geographical space c. című cikke. A történeti összefoglalást azok kezdik meg, akik a leginkább a földrajzi információk számítógépes információfeldolgozásának a közelében vannak, a térinformatikával foglalkozó geográfusok. 
${ }^{201}$ Az amerikai Ohio Állami Egyetem geográfus professzora.

${ }^{202}$ A logikai behaviorizmus elmélete szerint a mentális állapotok azonosak tényleges vagy hipotetikusan felvett viselkedésekkel, ami egyaránt igaz lehet az identitás számára multi-dimenzionális környezetében is. (Clark 1996, p. 40.) Lásd még Gilbert Ryle (1974): A szellem fogalma c. müvét.

${ }^{203}$ Kapcsolatok a valós és virtuális terek között (Kellerman 2002b, p. 38.)

${ }^{204}$ Amint azt korábban Kellermannál láthattuk. (vö. Kellerman 2006, p. 129.)

${ }^{205}$ A dolgozatom szempontjából nem releváns, hogy Clark valamennyi architektúráját, vagy az egyes sémák áttetszőségének fokozatait ismertessem.

${ }^{206}$ Az emergens séma lényege, hogy megragadja a mögöttes tudást, a megfelelő időben mozgósítva a háttérismeret alhalmazát. (Clark 1996, p. 135.)

${ }^{207}$ Paul Smolensky (1987): Connectionist AI, and the brain, Artificial Intelligence Review 1., pp. 95-109.

${ }^{208}$ Ilyen kezdeti megoldások voltak a Turing-gépen alapuló kutatási programok. A Turing-gép egy univerzális algoritmikus modell lényegében. Alan Turing (1937) angol matematikus a számítás (komputáció) fogalmát definiálta, és ez az elméleti eszköz lett a Turing-gép. Ennek megfelelően a mechanizmusoknak egy osztálya van, amelyet nem a fizikai felépítés határoz meg, hanem a szimbólummanipuláció formális tulajdonsága. Továbbá kimutatta, hogy képesek az emberi elméhez hasonlóan kezelni egy speciális problémát, és megmutatta, hogyan kell definiálni egy ún. univerzális Turing gépet, amely bármelyik másikat helyettesítheti, s kognitív feladatokat oldhat meg. Turing gépei azt sugallták, hogy ha formálisan is, de utánozni tudják az emberi elmét. Fontos megjegyezni, hogy a fizikai megvalósítást lényegtelennek tartotta, az elv volt a fontos. A lényeg, hogy bármilyen specializált kognitív feladatot el tudjon látni. Turing munkája révén a klasszikus kognitívizmus vált valóra. Az álom kiteljesedéséhez azonban kellett még egy általános digitális számítógép (Neumann János), és egy magas szintủ programozási nyelv (John McCarthy), ez volt a LISP (listaprocesszálás). (Clark 1996, p. 22.)

${ }^{209}$ Részletes kritikai elemzést lásd itt: Jerry A. Fodor, Zenon W. Pylyshyn (1988): Connectionism and cognitive architecture: A critical analysis, Cognition, 28/1988, pp. 3-71.

${ }^{210}$ Lásd itt Letenyei (2005): Mentális térképek szerkesztése.

${ }^{211}$ Az eltérő világbeli entitásokat megfeleltethetjük a kognitív pszichológiából vett standard szimbolikus atomoknak, olyan szimbolikus kifejezésekre alkalmazva őket, melyek részeit (atomjait) pontos szemantikai értelmezéssel lehet ellátni azon fogalmak és viszonyok a keretében, melyeket a köznyelv is megért. Atomi szavak (egyben térbeli entitások is lehetnek) pl. az asztal, a labda, a szerep, pálya, elektron stb. A számítógépek már ettől eltérő, az agyműködéshez jobban hasonlító értelmezési módokat használnak. (vö. Clark 1996, p. 26.)

${ }^{212}$ SZÁR - szemantikailag áttetszö rendszerek. A hagyományos MI modellek többsége ilyen. A rendszer akkor lesz áttetszö szemantikailag, ha van egy világos (entitás/standard szimbolikus atom) leképezés a számításokkal létrehozott állapotok és a szemantikailag értelmezhető mondatok között. (Clark 1996, pp. 33-38.) Ez jellemzően a népi pszichológiai irányzatok kedvelt irányzata, mint ahogy az új virágzásnak induló népi vagy közföldrajzi irányzatok esetében is tapasztalhatjuk ezt az egyszerübb, köznyelvi értelemben is áttetszőbb megfogalmazásokat elönyben részesítő publikációkat.

${ }^{213}$ PDP - párhuzamos megosztott feldolgozás (Parallel Distributed Processing). Andy Clark szerint a PDP architektúrát az idegrendszerről alkotott képünk ihlette. Az emberi kogníció oldaláról ezek olyan egységek, amelyek önmagukban talán túl lassúak, de együttesen kiemelkedő teljesítményekre képesek. Ilyenek például a látás és szenzomotoros vezérlés, vagy a mozgás és mozgás-orientáció. A legfontosabb jellemzőjük, hogy kis számítási teljesítmény mellé nagy hatékonyság párosul a hagyományos szimbólumfeldolgozó rendszerekkel szemben. (Clark 1996, pp. 123-153.)

${ }^{214}$ Hochmair és Frank (2001) javaslatával összhangban, in. Kellerman 2007, p. 20.

${ }^{215}$ A szemantikailag áttetsző rendszerek logikája szerint a gondolataink komputációs tevékenység eredménye, és ennek megfelelően a beszélt nyelv, a leíró fogalmaink, metaforákkal operáló gondolatiságunknak hasonlítania kell a köznapi beszédhez. Ez lényegében megfelel egy evolúciós vagy fejlődéslélektani megközelítésnek. (vö. Clark 1996, pp. 12-14.)

${ }^{216}$ Lásd például itt, a virtuális valóság lapon, ahol számos virtuális világ linkjét összegyüjtötték: http://virtualisvalosag.lap.hu/virtualis_vilagok_vr_worlds/11285949; utolsó elérés: 2010.09.02.

${ }^{217}$ Vö. Kellerman 2007, p. 21.

218 "Without the sense of location, distance, and direction necessary for the formation of configurational spatial knowledge, and without a habitual movement pattern essential for developing route-based spatial knowledge, an articulated cognitive map of cyberspace cannot be established (Golledge, 1995; 1999).” (Kwan 2001, p. 26.) 218 $^{12}$ 
${ }^{219}$ Ezt nevezi Mercator projekciónak Battersby és Montelló (2009): Area Estimation of World Regions and the Projection of the Global-Scale Cognitive Map c. cikkében, amelyben igen érdekes kísérletet tesznek a mentális reprezentációk globális kivetítésére. A vizsgálatot geográfus hallgatók között végezték, ami némileg csökkenti az általánosítás lehetőségét, hiszen ők előnyben voltak a felmérésben.

${ }^{220}$ Sinka 1999, 2005, 2006a, 2006d, 2007a. 1999-ben egy távközlő társaság megbízásából kellett térinformatikai rendszert fejlesztenem és a kistérség településeivel a kapcsolatot tartani. Minden egyes nézetet ki kellett nyomtatnunk a polgármesterek és hivatalnokok részére. A település-menedzsmentnek semmiféle tapasztalata nem volt a virtuális térképi terekkel. A projekt sikere ezt a szakadékot enyhíthette volna egy távközlési és települési információs rendszer bartel alapú létrehozásával.

${ }^{221}$ Mindkettő szorosan kapcsolódik a humán interfész-nélküliség problémaköréhez, amely az embert, mint a környezet-észlelés központját állítja a valós és virtuális terek közé, s amely összeveti az evolúciós és a tanulási észlelési kompetenciák paradigmáit, mintáit. Lásd még A konnektivizmus földrajza c. fejezet.

${ }^{222}$ E-learning rendszerek felmérésénél tapasztalták azt a paradoxonnak tűnő jelenséget, hogy a lineáris és a nem lineáris tananyagbejárást alkalmazó felhasználók összevetésénél a lineáris útvonalat követő metódus hatékonyabbnak bizonyult azokhoz képest, akik úm. csapongtak a tananyagelemek között, még ha azokat ad hoc fel is dolgozták. Ez ugyanis ellentmond annak a tapasztalatnak, hogy életünk során jellemzően ad hoc, asszociatív tapasztalati úton tanulunk meg nagyon sok dolgot. Tapasztaljuk, átéljük, gyakoroljuk, de nem foglalkozunk annak elméleti keretével, vagy a teljes kapcsolódó ismeretanyaggal. A hatvanas-hetvenes évek uralkodó elmélete is az volt, hogy szimbolikus jelek sorozatával végezzük a környezetünk megismerését. Ezek a szemantikailag áttetsző, szimbólum és jelentés párokra épülő elméletet nevezzük SZÁR-nak, vagyis szemantikailag áttetsző rendszereknek.

223 „... that accessibility to information resources in cyberspace depends not only on the availability of connecting devices and services, but also on a person's knowledge and skills in using navigational aids and search tools. [...] it acknowledges the importance of personal factors or situations in affecting individual accessibility to resources in cyberspace. These include personal attributes such as gender, race, age, income, prior training or knowledge in using access devices, and the availability and use of off-line information sources (such as printed materials or information from colleagues)." (Kwan 2001, p. 28-29.)

${ }^{224}$ Publikáció alatt olyan kimenetet értek, melyek a befogadott környezeti információkból, belső folyamatok által keletkeznek és azok egyéni reprezentációként valamilyen információhordozón publikálásra, megjelenítésre, közlésre kerülnek. Ilyen lehet egy mentális térkép rajza, egy verbális kommunikáció (pl. tájékoztatunk, valakit az utcán mit hol talál), egy web blog a nyaralásról, de a válogatott képek bemutatása családi körben vagy egy képmegosztó alkalmazás segítségével is hasonló aktivitást jelent. A tipográfiai formátumú publikációk (cikk, levél, könyv, blog bejegyzés stb.) is ide tartoznak, ráadásul igen izgalmas transzformációk során a valós és virtuális miliőből egy tipográfiai (textualitás szabályai szerint szerveződő) térbe transzformált, alakított kimeneti publikáció történik. Az izgalmat itt az okozza, hogy a többszörös tér-konverzió miatt minden továbbadott kimenet egy új leképezéssel rendelkező, egyéni konstrukció lesz. Az alap információkészlet magja is erodálódik, és néhány szelektált eleme marad meg csupán.

${ }^{225}$ Funkcionális szerepkörökre gondolok, úm. információt hordozó, tároló, közvetítő, befogadó, feldolgozó stb., amelyeket az észleléstől a publikációig bármely szakaszban betölthet az entitás, illetve rögzítheti az egyes információkat és speciálisan arra csak egy-egy funkciót alkalmaz: bizonyos információt csak hordoz vagy csak továbbít stb.

${ }^{226}$ A mobil és a rögzített terek között egyértelmű különbséget a fizikai hozzáférés kötöttsége tesz. Ez számos szolgáltatás esetében egyre erősebben érvényesül, hovatovább reneszánszát éli. Olyan szolgáltatásokra gondolok, mint például a könyvtári szolgáltatások közül egyes adatbázisok bibliográfiai vagy teljes szövegü hozzáférése, amely kizárólag egy-egy oktatási intézmény belső hálózatából érhetők el. Nem csak ilyen szolgáltatások jelennek meg azonban a helyhez kötötten, de újabb ingyenes web 2.0-ás szolgáltatásokat is találhatunk, amelyek egy adott fizikai címmel rendelkező objektumhoz rendelik magukat, illetve nyilvántartják azokat, akik azt a szolgáltatást aktuálisan igénybe is veszik. Így könnyen követhetővé válnak ismeröseink, családtagjaink, $\mathrm{s}$ ha nem találjuk éppen otthon őket, akkor is tudhatjuk, hol tartózkodnak, s akár a helyszínen, akár virtuálisan fel is kereshetjük öket. Az egyik ilyen közismert „nyomkövetö” szolgáltatás a Twitter (http://twitter.com), de újabban megjelennek mások is, mint például az „okos telefonokra” tervezett Foursquer (http://foursquare.com/) vagy Gowalla (http://gowalla.com/). Ráadásul az említett szolgáltatások egymással is kompatibilisek és átvehetők a másutt tárolt adatok, profilok (lásd korábban a mutual compatibility elvét). Ez utóbbiak tehát szintén helyhez rögzítettek, csak éppen a szolgáltatáson belül rögzítik a lokációkat, és nem a szolgáltatást a lokációhoz. 
${ }^{227}$ Ne feledjük el, hogy az információ áru! A kapitalista gondolkodásmód itt is fontos aspektus lesz, mint ahogy azt Kellerman információs társadalom elemzésének történeti fázisainál és értelmezési dimenzióinál már láthattuk.

${ }^{228}$ David Harvey (1981): Conceptual and measurement problems in the cognitive-behavioral approach to location theory, in. Kevin R. Cox,Reginald G. Golledge (ed.): Behavioral problems in geography revisited, Methuen, New York 1981, pp. 18-42., in. Cséfalvay 1990, p. 71.

${ }^{229}$ Térbeli kogníció és kognitív térképek (Kellerman 2007, p. 8.)

${ }^{230}$ Harvey (1981), in. Cséfalvay 1990, pp. 71-74.

${ }^{231}$ Primary personal spatial experience

${ }^{232}$ Signal sign-process

${ }^{233}$ Secondary personal spatial experience

${ }^{234}$ Symbol sign-process

${ }^{235}$ Spatial cognition (aggregate knowledge of an area)

${ }^{236} \mathrm{Az}$ empirikus tapasztalatok szerint az internetezők többsége rendszeresen alig néhány weboldalt olvas, és az újabbak felfedezésére sem szán néhány percnél többet hetente. Az emberek többsége egy-két levelezöt,

keresőmotort vagy szótárat, illetve hírportált használ. A hálózati struktúra, ahogy azt a következő fejezetben látni fogjuk, szerveződési modellje visszaigazolja ,a győztes mindent visz” topológiáját, a csomópontok

kiemelkedését, a többiek negligálódását. Az új szájtok virtuális terének vizuális és tipográfiai adaptációja agyunk számára megterhelő folyamat. Nem véletlenül dolgoznak a web grafikusok olyan sokat a weboldalak navigációs rétegeivel, a világos menürendszer kialakításával és a megragadó, de harmonikus színdinamikával.

${ }^{237}$ A feldolgozási metódusokról később esik szó: SZÁR - szemantikailag áttetsző rendszerek, PDP párhuzamos feldolgozási folyamatok, LDP - lineáris feldolgozási folyamatok (az előző analógiájára).

${ }^{238}$ Az evolúciónak köszönhetően egy virágos réten a pszichológiai kutatások szerint néhány másodperc és néhány perc közötti időtartam alatt találjuk meg a keresett növényt, azonosítva az élőhelyét, és kiszürve a többi közül a növényre jellemző morfológiai jegyeket (levél, virág, szín, méret stb.). Egy nagymacskát, ugyanazon a biotópon a másodperc ezredrésze alatt képesek vagyunk kiszúrni. Közvetlen érzékeléssel ez lehetetlen lenne, kell hozzá a sebesség, és ahogy később szó lesz róla, a megfelelő agyi feldolgozási metódus is.

${ }^{239}$ Elérkeztünk a környezeti információ olvasási kompetenciájához. Klasszikus példa a tipográfiai generalizáció, amikor az egyes nyelvek eltérő módon generalizálják a hangokat, és egymástól teljesen eltérő írásmódok, jelrendszerek, lényegében ábécék alakulnak ki. A leginkább képszerü hieroglifáktól, és a keleti képi írásjelektől saját nyelvünk írásmódjának változásáig tudunk erre példát hozni. Mi magunk sem tudjuk például régi magyar szövegeinket megfelelő fordítás nélkül elolvasni. Ugyan ez igaz az eltérő nyelvek, eltérő logikája szerint megfogalmazott piktogramokra is. Nem véletlenül mutat az egységes generalizáció felé a kartográfusok generalizált térképi jelrendszere, és például a közlekedési táblák nemzetközi összehangolása, hogy csak a leggyakoribb térbeli információszerzésre használt másodlagos forrásokat említsem.

${ }^{240} \mathrm{Az}$ e-learning szolgáltatás fejlesztése során szerzett tapasztalat azt mutatja, hogy a legalapvetőbb térváltási procedúra is problémát okozhat, ha előtte a felhasználó nem rendelkezik a szükséges kompetenciákkal. Mielőtt arra gondolnánk, hogy speciális, a számítógépekhez egyedileg kifejlesztett képességek szükségesek, elárulom, hogy nem. Az empirikus felméréseim és vizsgálódásaim azt igazolták, hogy a sztenderd, általános iskola alsó tagozatában megszerezhető alapkompetenciák magabiztos használatára kell csupán építeni: néma értő olvasás, gyorsolvasás, alapvetö kombinatorika és logika, helyesírás, alapvető szövegkompozíciós képességek kialakítása, szövegértés, újrafeldolgozás és reprodukálás stb. ugyanez igaz a környezetismeret, mint a földrajz és a többi természettudományos tárgy alapozása tekintetében is. A foiskolai és egyetemi hallgatók körében végzett kísérleteim azt mutatják, hogy az említett készségek fejlesztésével egy-egy félév, illetve a diplomamunka elkészítésének idejére már sikerként értékelték a saját munkájukat az e-learning rendszerben, és a kezdeti passzív attitűd többségüknél egy pozitív miliővé változott. (Sinka 2005, 2006a, 2006c, 2006d, 2008, 2009a, 2010)

${ }^{241}$ Megemlíthetjük itt például a könyvtárakban egyéb tanulási központokban az informális tanulásról származó adatokat (http://appsso.eurostat.ec.europa.eu/nui/submitViewTableAction.do?dvsc=0), vagy a könyvtárlátogatást is vizsgáló kutatási eredményeket, és nem utolsó sorban a hazai könyvtárhasználatot reprezentáló adatok statisztikai és kutatási jelentésekben publikált forrásait

(http://portal.ksh.hu/pls/ksh/docs/hun/xstadat/xstadat_eves/i_zkz002a.html).

${ }^{242}$ Az ember manipulációs terét extenzionáló technikai eszközök sokáig a fizikai értelemben vett kiterjesztésre koncentráltak: gyorsabb, hosszabb, erősebb. Ilyen volt a kerékpártól a repülőgépig minden, ami a mobilitást szolgálta, és biztosította azt, hogy elérhessük azt, amit kell. A testi extenzió tehát első lépésben a karunk meghosszabbítása volt, és függött a természeti földrajzi determináltságtól (felszíni adottságok, időjárási 
viszonyok, éghajlati adottságok stb.). Az ezredfordulót követően berobbanó IKT egy olyan jelenséget produkált, amellyel a testi extenziót nem csak vertikálisan és horizontálisan terjesztette ki addig nem várt méretekre (pl. több millió kilométerre müködő, irányítható ürszondák, és globális kábelhálózatok a földfelszínen), de létrehozta az egyidejüség lehetőségét. Egyidejüség az a jelenség, amely felforgatja a hagyományos sémákat mind a manupulatív tér, mind az észlelés tekintetében. (Vö. Janelle 1973, p. 11, és Kellerman 2007, p. 18.)

${ }^{243}$ Ráadásul nem csak az egyszerủ munkafolyamatok esetében, hiszen éppen modern gyáripar és az automatizált gépsorok, az egyre kisebb részletekre bontott gyártási folyamatok eredményeképpen egyre alacsonyabb végzettségű szakmunkásokra van/volt szükség. Egy szük elit kifejleszti a terméket, de a gyártás maga már olyan apró részletekre bontott, hogy a napi rutin ellátását biztosító mozgáskoordinációtól nagyobb bonyolultságú motorikus képességre nincs is szükség. Természetesen nem a szakmunkás vállalkozóról beszélek, hanem a globális vállalatok termelési hálózatairól, azokról, akik a leginkább építenek a modern információs és kommunikációs technológia vívmányaira. Az „infokommunikáció” kifejezés szétválasztása itt a termelés és irányítás szétválasztására utal. Az ezredfordulót, de különösen a 2005-től megjelenő publikációkban az IKT (ICT) kifejezése nem információs és kommunikációs technológia, hanem infokommunikációs technológia, utalva a két irányzat egyre szorosabb szinergiájára.

${ }^{244}$ Vö. Batty korábban bemutatott hely tér elméleti felosztását a kibertérrel kapcsolatban. (Batty 1997, p. 340.)

${ }^{245}$ A nyelvi és a tipográfiai tér lényege itt mutatkozik meg. A körülöttünk lévő földrajzi környezet leírása az észlelés során keletkező reprezentációkból generált fogalmainkból születik. A sarkkörök mentén élő eszkimók számára a hóval-jéggel fedett felszínre közvetlenül néhány tíz szavuk van, közvetve pedig közel kétszáz olyan kifejezést használnak, amellyel le tudják írni a hó és jég minőségét. Absztrakt terek létrehozása és megnevezése is akkor lehetséges, ha van fizikai tapasztalati terünk (hozzá kapcsolódó nyelvi kifejezésekkel), és abból tudunk építkezni.

${ }^{246}$ Pléh Csaba (1997): Szekvenciális és párhuzamos modellek a kognitív pszichológiában - a PDP megközelítés történeti helye, In. A megismeréskutatás egy új útja: A párhuzamos feldolgozás, szerk. Pléh Csaba, Typotex Kiadó 1997, pp. 13-57.

${ }^{247}$ Rigler András: Az információs társadalom kialakulása érdeklődés hiányában elmarad, ITTK Kutatások, World Internet Project, forrás: http://www.ittk.hu/web/docs/wip_rigler_infoelmarad.pdf, utolsó elérés: 2010.09.01.

${ }^{248}$ Kellerman eredeti hivatkozása szerint a forrás: Kellerman 2002, Li et al. 2001, Dodge and Kitchin 2001, Graham 1997., in. Kellerman 2007, p. 12.

${ }^{249}$ 5. ábra Valós és virtuális terek összehasonlítása (Kellerman 2007, p. 12.). Fordítás tőlem (soronként): dimension - dimenzió; real space - valós tér; virtual space - virtuális tér; organization - szerkezet; content tartalom; physical and informational - fizikai és információs; informational - információs; places - helyek; separated - elkülönült; converge with local real ones - vegyül helyi valós helyekkel; form- forma; abstract or real - absztrakt vagy valós; relational - egymással összefüggő (relációs); size - méret; limited - korlátolt; unlimited - korlátlan; construction and maintenance - felépítés és fenntartás; expensive and heavly controlled drága és erősen irányított; reasonably priced and lightly controlled - elfogadható árú és lazábban irányított; space - tér; territory/euclidean - terület alapú/euklideszi; network/logical - hálózat/logikai; matter - anyag; material/tangible - materiális/kézzelfogható; immaterial/intangible - immateriális/nem kézzelfogható; movement - mozgás; medium - közeg; transportation - szállítás; telecommunication - telekommunikáció; speed sebesség; depends on the mode of transport - a szállítás módjától függ; speed of light, constrained by infrastructure, costs, regulations - fénysebesség, az infrastruktúra, költségek és szabályozások korlátozzák; distance - távolság; major constraint - a legfőbb korlát; does not matter mostly - általában nem számít; time idő; matters - számít; matters, but events can be suspended in time - számít, de az események felfüggeszthetők az időben; orientation - irány (orientáció); matters - számít; does not matter - nem számít; users - felhasználók; identity - személyazonosság; defined - meghatározott; independent of identity in real space - a valós térbeli személyazonosságtól független; experience - élmény; bodily - testi; imaginative and metaphorical - képzelt és metaforikus; interaction - interakció; embodied - testi; disembodied - nem testi; attitude - magatartás/attitüd; long-term commitment - hosszú távú elkötelezettség; uncommitted - nem elkötelezett; language - nyelv; national-domestic - nemzeti-belföldi; mainly english-international - többnyire angol-nemzetközi;

${ }^{250}$ A kognitív disszonancia olyan belső, mentális feszültség, amit egy, az eddigi tapasztalatainknak ellentmondó új információ válthat ki. Ilyenkor előfordul, hogy saját információkészletünkre épülő értékrendünk és mentális reprezentációink ellenében döntünk, vagy éppen döntésképtelenné válunk. Kwannál láthattunk ehhez hasonló utalást a disz-orientáció és a túltöltődés (overhead) kapcsolatára vonatkozóan.

${ }^{251}$ Egy japán kutatás összevetette a valós és virtuális társadalom szereplöit. Azonosítva és összevetve a két térben identitással rendelkező személyeket kiderült, hogy a két társadalom nem is tér el olyan markánsan. A 
valós térben bevett szociális attitüdök tökéletesen leképeződnek a virtuálisban is. A negatív személyiségjegyek nem egy másik ént jelölnek a kibertérben, hanem ugyanannak a személynek a létező, csak a valós világban rejtett, a szuper ego által felülírt és kontrollált verziója.

${ }^{252}$ Az intenzió: az az általános feltétel, amelyet egy objektumnak teljesítenie kell, ahhoz, hogy egy szóval jelölhető legyen. kék szó - a kékség tulajdonsága. Az extenzió: egy kifejezés extenzióját mindazon dolgoknak osztálya alkotja, amelyekre az illetö kifejezés vonatkoztatható. kék - az összes dolog kék. Ahhoz, hogy egy adott nyelven megértsünk egy szót, tudnunk kell, mi az intenziója, de ugyanakkor elegendő tapasztalati ismerettel kell rendelkeznünk a jelölt objektummal kapcsolatosan, hogy lássuk: teljesíti-e az általános feltételt (extenzió) ahhoz, hogy az illetö szóval (saját nyelvi textusunkban) jelölhessük.

(http://jelkepesseg.wordpress.com/2010/03/23/jelhelyzet-vagy-jelfolyamat/)

${ }^{253}$ Vö. Pléh Csaba (2002): A transzparencia: a gondolkodás köznapjaitól a kognitív tudományig, In.: Gábor Forrai,Tihamér Margitay (szerk.): Tudomány és történet, Typotex Kft. 2002., in. pp. 201-213.

${ }^{254}$ A nemzetközi irodalomban több irányzat is életre kel, föleg az infrastruktúra irányából, de nagyon hamar szociologizáló és magatartástudományi aspektusok is belekerülnek ezekbe a munkákba. Például modernebb, hálózati szemléletủ városértelmezést találunk például Stephen Graham (2002): FlowCity: Networked Mobilities and the Contemporary Metropolis c. dolgozatában, vagy a mérnöki szempontok adaptációját találjuk Paradiso (2006): Information Geography: A Bridge between Engineering and the Social Sciences c. cikkében.

${ }^{255}$ Vö. Abonyi Gyuláné, Krajkó Gyula (1995): Fejezetek Magyarország gazdaságföldrajzának tanulmányozásához, JATEPress 1995., p. 94., illetve vö. Abonyiné Palotás Jolán (2003): Infrastruktúra, Dialóg Campus, Bp. 2003, pp. 19-20. és p. 25.

${ }^{256} 1995$ és 2000 között például a JászTel Rt. (ma az Invitel cégcsoporthoz tartozó) koncessziós területén a teljes alépítményi és léghálózatot kicserélték. A MATÁV-tól örökölt hálózat sem bővítésre, sem korszerủ szolgáltatások nyújtásához nem volt alkalmas.

${ }^{257}$ Lásd korábban Castells kapcsán.

${ }^{258}$ A szolgáltatási oldalon az e-közigazgatás, e-kormányzat stb. programokat értjük, míg a közösségi terekhez jellemzően a web 2.0 jelzővel illetett tartalommegosztó és kollaboratív tevékenységet biztosító technológiák tartoznak ide.

${ }^{259}$ Erdősi Ferenc (2005): Magyarország közlekedési és távközlési földrajza, Dialóg Campus Kiadó 2005.

${ }^{260}$ Castells 2005, pp. 494-552. Castells munkája eredetileg az ezredfordulón jelenik meg a fejlett kapitalista nyugaton, amikor nálunk csak ébredezik a rendszerváltást követő magánszféra. A hálózatosodást, az innovációt ekkor még döntően a multinacionális cégek jelentik, s köréjük gyülik a külföldi müködő tőke által az innovációs miliö.

${ }^{261}$ Lásd ide még az Egy dualista térkonstrukció születése c. fejezetet.

${ }^{262}$ Lásd például Hudson-Smith et al. 2009, vagy Warf 2001-ben készült munkáját, tagadva a „földrajz végét” tagadva új utakat keres.

${ }^{263}$ vö. Kulcsár Zsolt (2009): Hálózati tanulás, In. Oktatás-Informatika 2009/1., pp. 4-13.

${ }^{264}$ A kulturális földrajzon nem a hagyományos értelemben vett emberföldrajz fizikai- és kultúrföldrajzi bontását, vagy egy kultúrantropológiai beágyazottságú etnoföldrajzot, és nem is kizárólag a hagyományosan vett kulturális infrastruktúrát értem. Közelebb áll hozzám Carl O. Sauer koncepciója, amely nagyobb hangsúlyt fektet a környezet formálására, kulturális egyediségére, valamint Leslie White antropológus kulturális alrendszerei, amelyek egyének és csoportok közötti interakciót, hálózati kapcsolatot is beemelik a technológiai és az ideológiai rendszerek közé.

${ }^{265}$ A módszertan tekintetében a legelemibb metódus az információfeldolgozás alapsémája: (1) az információ felismerése és összegyüjtése; (2) rendszerezése; (3) tárolása; (4) újrafeldolgozása (reprocesszálás); (5) publikálása.

${ }^{266}$ A technológia úm. belső (insider) megközelítése azt jelentheti, hogy a tudományos kutatások és a technológiai újitások folyamatosak, bár szakaszosság fellelhető, de a kontinuitás állandónak tekinthető. Az úm. külső (outsider) megközelítés ellenben azt mondja, hogy a technológiai fejlődés lelassul, vagy inkább mesterségesen lassítani kell, mert az emberi faj sokkal lassabban reagál a változásokra. Például a személyi számítógépek jelenleg olyan fejlettségi szinten állnak, amikor sem technológiailag, sem anyagilag nem terhelő egy olyan eszköz munkába állítása, amely az adott feladatot ellátja (az irodai munkától a tudományos kutatásokig). A valódi korlátot a humán interfész jelenti. Az emberek többsége nem végez a hétköznapokban olyan tevékenységek, amelyhez a PC-je erőforrásait maximálisan kihasználná. Erre egy tipikus példa az eszközgyártók visszalépése, amikor a felhasználók érdekeit inkább figyelembe vevő ún. vékony klienseket 
kezdtek el gyártani. Ennek felfutása eredményezte az ún. netBook és netPC típusú eszközöket, amelyek csökkentett teljesítménnyel, az átlag igényt igyekeztek, ráadásul olcsóbban kielégíteni.

${ }^{267}$ Tér-indikátorok: azokat nevezem tér-indikátoroknak, amelyek a relatív - hosszú időn át tartó, vagyis nemzedékeken belül stabilnak mondható térbeli struktúrák - ún. nyugalmi állapotához képest változásokat idéznek elö, a meglévő szerkezeteket megbontják, és új alakzatokat hoznak létre. Azzal persze lehet vitatkozni, hogy miért generációs léptékre hivatkozom. Elsősorban azért, mert - bár nem stabil határvonallal meghúzható intervallumról van szó - ez az egyetlen, ami emberi léptékkel belátható egység (időben és térben). illanatnyi életünk ugyanis aligha fogja fel például a történeti korszakokat, legfeljebb beszélünk róla, értékelni, látni csak később tudjuk. Ahogy a járási rendszer, mint egykori katonai egység létezett és létezik még ma is, az egy napi járóföldet jelentette. Ezt ugyan torzítja a technológiai forradalom által okozott tény, hogy a gépkocsi használat miatt az addigi napi járóföldnek számító 30-35 km mára átlag 45-50 km-re emelkedett. Érdemes azonban figyelni azokra az elemzésekre, amelyek például az autópályák gazdaságélénkítő hatását kutatja, ahol azonban a gazdaság vérkeringésébe ténylegesen bekapcsolódni tudó települések autópálya vonalától mért távolsága rendre 30-35 km-t határoz meg. Furcsa egybeesés ez akkor, amikor a technológia többet is enged, a fizikai és mentális képességeink azonban az ősi reflexek szerint müködnek tovább. Ugyanez igaz a belső migrációra, és a napi ingázókra is.

${ }^{268}$ A behaviorista geográfia szemlélete már tartalmazott pedagógiai elemeket, nem volt tisztán pszichoanalitikus integráció.

${ }^{269}$ A tanulási folyamat vizsgálata (tanulás időföldrajza), a didaktikai célok és eredmények elemzése (virtuális kurzusok tere, virtuális és fizikai interfészek (VFI), humán interfész-rések (HIG), a bemeneti és kimeneti szintek meghatározása, a követelményszint által módosuló tanulási stratégiák változásának elemzése (internet, web2.0, e-learning, utazási szokások, tér-idő függetlenség, digitális benszülöttek/emigránsok).

${ }^{270}$ Mit értek entitás, szubjektum és egyén fogalmán? A szubjektum, mint egyén olyan entitás, amely több attribútummal rendelkezik, mint maga az entitás. Az entitás egyszerü hordozó, neutrális fogalom. A szubjektum, az entitástól bővebb, de továbbra is egyedi eleme egy csoportnak. A jellegét föleg az határozza meg, hogy a csoportkapcsolatain túl saját döntéshozatali mechanizmussal is rendelkezik. Az entitás nem. Egyedi elem, amely a csoport nagyságától és szerkezetétől függetlenül viseli magán a legjellemzőbb attribútumokat. Ö az átlag, a standard, specifikációk nélküli elem. - Az egyén, mint szubjektum inkább a csoport tagja. A csoport szintjén még érvényesülnek a szubjektív hatások. A társadalom (mint a legnagyobb csoport) szintjén azonban inkább entitásként jelenik meg. A szubjektum ez utóbbiban háttérbe szorul, a legfontosabb, bonthatatlan attribútumokat hordozva csak magán. Az egyén is visszaszorulhat (pl. funkcionalitása, aktivitása miatt), de legfeljebb egyet lép, a szubjektum szintjére. A csoportméret tehát számomra meghatározhatja, hogy humán entitásról, szubjektumról vagy egyénről beszélünk. Az entitás a neutrális egyediséget, a szubjektum valamely attribútum fontosságát, jelzi, míg az egyén egy komplex testreszabott (szubjektív) információkészlettel rendelkező tagja a társadalomnak. Az entitás a folyamatok modellezéséhez kell, a szubjektum a csoport jellemző attribútuma miatt a csoport-egyén, csoport-csoport, egyén-egyén és azok belső, külső kapcsolatának értelmezéséhez nyújt értelmezési keretet. Az egyén már társadalmi meghatározottsággal (pl. osztályjelzővel) rendelkezhet, így ezektől magasabb kategóriát képvisel értelmezésem szerint. - Mark Granovetter (1973) egyébként EGO-nak nevezte kutatásában az átlagos csoportkapcsolatokkal rendelkező egyént, akit én standardizált entitásnak vagy szubjektumnak neveztem.

${ }^{271}$ Adams, Janelle, Yu H., Shaw., és Kwan kapcsolódó munkái érdemelnek figyelmet.

${ }^{272}$ Dinamikus topológiákra kiváló példa a mobil hálózatok rögzített és a vevő, mint csomópont relatív és valós mozgásával kialakuló hálózati egységek.

${ }^{273}$ A hálózati logika karakterisztikája Inkinen (2003) munkájában is felbukkan.

${ }^{274}$ Lásd WIP kutatási jelentéseit és az ITTK kiadványait (http://www.ittk.hu/web/kiadvanyok.html), valamint a MoodleMoot konferenciákon elhangzott előadásokat. - A Moodle egy szabad forráskódú e-learning keretrendszer, amely a felsőoktatás, a közoktatás és a vállalati szféra, különösen az olcsóbb megoldásokat keresö KKV-k között igen népszerủ tanulástámogató rendszer. A MoodleMoot konferenciasorozat a keretrendszer használatával kapcsolatos technikai és módszertani, informatikai és oktatásmódszertani menedzsmenttel kapcsolatos kérdéseket vitatja meg évről évre. Az itt elhangzott előadások jelentős része elérhető a http://moodlemoot.hu oldalról.

${ }^{275}$ A kritikus tömeg eléréséhez az első 'csapást' az oktatáson keresztül és a benne szereplők kapják. Ha igényszintjük eléri a kívánatos értéket, a folyamat átszivárog a többi társadalmi szférába. Az evolúciós kör első spirálja lezárul.

${ }^{276}$ A kritikus tömeg (ISCM= Information Society Critical Mass): az infokommunikációs technológiák olyan mértékü elterjedése és elfogadottsága a társadalmi és gazdasági életben, amely következtében azok folyamataiban minőségi változást eredményez. 
277 Számos információs társadalomra vonatkozó mérési metódus és számítási mód létezik. Talán a legnépszerübbek az ITU, International Telecommunication Union elemzése: http://www.itu.int/ITUD/ict/publications/idi/2009/material/IDI2009_w5.pdf; vagy az IDC, International Data Corporation indexe: http://www.idc.com/groups/isi/main.html; utolsó elérés: 2010.09.12.

${ }^{278}$ Nemzetközi tapasztalataim alapján a problémakör angol megfelelőjeként szerensésebb a „rés” (gap) kifejezés használata, míg magyarul gyakran használom az interfész-hiány, az interfész-nélküliség kifejezéseket, mert szerencsésebben fejezi ki a háttérben zajló folyamatokat.

${ }^{279}$ A hardveres oldalt a technológiai réteg biztosítja.

${ }^{280}$ http://www.ala.org/ala/professionalresources/atoz/profresourcesinfolit/information_literacy.cfm

${ }^{281}$ http://www.ala.org/ala/mgrps/divs/acrl/standards/informationliteracycompetency.cfm;

Information Literacy Competency Standards for Higher Education (Információs Írástudás Kompetencia Standardok a Felsőoktatés számára): http://www.ala.org/ala/mgrps/divs/acrl/standards/standards.pdf

${ }^{282}$ Általában az emberi erőforrás, mint tudás allokáció. Itt most nem munkaerőpiaci tényezőként értem.

${ }^{283}$ WIP forrás: http://www.ittk.hu/web/wip.html

${ }^{284}$ http://www.kozhaloportal.hu/

${ }^{285}$ Lásd még innen a Szociális bizalmi index és internethasználat az európai országokban c. gafikont és a kapcsolódó fejezetet, in. Csepeli és Prazsák (2010): Örök visszatérés?, Társadalom az információs korban, Jószöveg Mühely 2010., pp. 194-203.

${ }^{286}$ Lásd még Bessenyei 2007, Bessenyei és Tóth 2008

${ }^{287}$ A hálózatok egyes rétegei külön is kutatható területek lehetnek: fizikai, logikai, alkalmazási, transzport, iternet és hálózati interfész rétegek a TCP/P protokol szerint. Ez egyébként szolgáltatáscentrikus megközelítés, ami könnyebben fordítható le térbeli vetületekre.

${ }^{288}$ Lásd például Barry Wellman professzor ide vonatkozó kutatásait:

http://homes.chass.utoronto.ca/ wellman/publications/; utolsó elérés: 2010.09.06.

${ }^{289}$ Hollandia a kontinens optikai hálózatának egyik legfontosabb kapuja.

290 1664-ben lett Új Amszterdam a britteké, s ezt követően kapja II. Jakab yorki hercegről a New York nevet.

${ }^{291}$ Európai Uniós kutatási anyagok is e megközelítés mellett szólnak: Studies in the context of the e-learning initiative: virtual models of european universities (2004), forrás:

http://www.elearningeuropa.info/extras/pdf/virtual_models.pdf; utolsó elérés: 2010.09.14., lásd még: Mayer (2007): What Is the Role of the University in Creating a High-Technology Region? c. cikkét szintén.

${ }^{292}$ Ahlqvist és Inkinen (2007): Technology foresight in scalar innovation systems: a spatiotemporal process perspective c. cikkében az északi országok innovációs központjait vizsgálva hasonló következtetésekre jut. A kutatás-fejlesztések valós téridő skáláján a nemzeti és regionális szint helyett a globális és a lokális szintek kerülnek előtérbe és az innovációs miliők köré szerveződnek, melyek központjában a kutatóközpontok, egyetemek állnak.

${ }^{293}$ Lásd itt még az EU Building the knowledge society: social and human capital interactions (2003) c. munkaanyagát.

294 vö. Adams (1995, p. 273.) Personal extensibility c. idő-tér kiterjesztés diagramjával, vagy Kellerman (2009b, pp. 50-52.) The End of Spatial Reorganization? Urban Landscapes of Personal Mobilities in the Information Age cikkével.

295 Tóth, Máté (2009): Pushing the boundaries of accessibility - Governmental efforts on ensuring equal access to information to rural library users (1997-2007) - In: NETCOM Volume XXIII (2009) 1/2. - Hungarian Information Society - Selected Studies - guest editor: Robert Sinka

${ }^{296}$ Vincze Andrea (2010): Közművelődési könyvtárak lehetőségei konnektivista szemmel, forrás: http://www.scribd.com/doc/30374011/Kozm\%C5\%B1vel\%C5\%91desi-konyvtarak-lehet\%C5\%91segeikonnektivista-szemmel; utolsó elérés: 2010.09.12.

${ }^{297}$ A virtuális tanulási terek felhasználása tekintetében magam is végzek e területen kutatásokat. A Szent István Egyetemen az e-learning és az e-portfólió keretrendszerek fejlesztésével, oktatásával jelentős empirikus tapasztalatot szerezhettem a virtuális és valós terek használatának problémaköréröl. (Sinka 2009a, 2010.)

${ }^{298}$ Lásd a Wikipédia generációról szóló előadást: Ollé János: Egy módszer alkonya: a katedrapedagógia végnapjai a felsőoktatásban - In. Korszerű felsőoktatási pedagógiai módszerek, törekvések - BCE Tudományos konferencia, 2010.04.30. 
${ }^{299}$ George Siemens (2004): Connectivism. A learning theory for the digital age., Elearnspace, 2004. december 12., forrás: http://www.elearnspace.org/Articles/connectivism.htm;

${ }^{300}$ Castells, Manuel. The Information Age. Economy, Society and Culture. Oxford; Malden, MA: Blackwell, First edition 1996-1998 (forrás: http://www.manuelcastells.info/en/obra_index.htm)

${ }^{301}$ Barabási, A. L., (2002) Linked: The New Science of Networks, Cambridge, MA, Perseus Publishing.

${ }^{302}$ Letenyei László: A kapcsolatháló regénye (recenzió), Barabási Albert László: Behálózva. Magyar Könyvklub, 2003., forrás: http://www.socialnetwork.hu/cikkek/barabasirecenziohun1.pdf

${ }^{303}$ „Connectivism presents a model of learning that acknowledges the tectonic shifts in society where learning is no longer an internal, individualistic activity. How people work and function is altered when new tools are utilized. The field of education has been slow to recognize both the impact of new learning tools and the environmental changes in what it means to learn. Connectivism provides insight into learning skills and tasks needed for learners to flourish in a digital era." (Siemens 2004)

${ }^{304}$ Ez a radikális változás valójában rendkívül lassú folyamat, legalábbis a technológia adta lehetőségekhez képest az, s ehhez elég betekinteni például Z. Karvalics László (1995): Az általános iskolai informatikaoktatás helyzetének és fejlesztésének általános kérdései c. anyagába. Észrevételei még mindig naprakészek, ráadásul már ekkor kiemelten foglalkozik könyvtártechnológiai (és funkcionalitási) kérdésekkel.

${ }^{305}$ Armani és Rocci (2003): Conceptual Maps in e-learning, How map based interfaces help the contextualization of information and the structuring of knowledge c. cikkükben kiváló metódusokat vázolnak mind a konceptuális tudástérképek, mind a hipertextek kutatása terén, hansúlyozva mindemellett a lehetőségét annak, hogy egy hibás didaktikai dizájn könnyen elveszetté tesz bennünket a tudás kiberterében. 